Líbia da Graça Pires

\title{
TEORIA DA DISTRIBUIÇÃO DINÂMICA DO ÔNUS DA PROVA NO PROCESSO DO TRABALHO
}

\begin{abstract}
Tese de Doutorado apresentada ao Departamento de Direito do Trabalho da Faculdade de Direito da Universidade de São Paulo, como requisito parcial para obtenção do título de Doutor sob a orientação do Professor Doutor Sérgio Pinto Martins
\end{abstract}

Faculdade de Direito da USP

São Paulo

2011 


\section{SUMÁRIO}

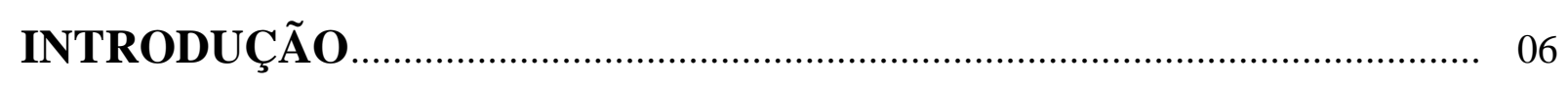

I. O TEMA A SER DESENVOLVIDO E SUAS LIMITAÇÕES ................................ 06

II. JUSTIFICATIVA DA ESCOLHA E DA IMPORT ÂNCIA DO TEMA ..................... 08

III. PRINCIPAIS QUESTÕES A SEREM ANALISADAS .................................... 09

IV. CONTRIBUIÇÃO ORIGINAL À CIÊNCIA JURÍDICA BRASILEIRA.................. 10

V. METODOLOGIA A SER UTILIZADA ...................................................... 11

\section{CAPITULO I - PROCESSO, DIREITOS FUNDAMENTAIS E DIREITO À PROVA NA PERSPECTIVA PROCESSUAL FUNDAMENTAL ........ 13}

1. Questões introdutórias.. ................................................................................... 13

2. Os direitos fundamentais.................................................................................. 14

2.1. Breve passagem histórica.................................................................................. 14

2.2. Noção, funções e dimensões dos direitos fundamentais............................................... 23

2.3. Eficácia dos direitos fundamentais - aplicabilidade e vinculação ................................ 30

3. Direitos fundamentais, processo e tutela constitucional do processo ............................. 33

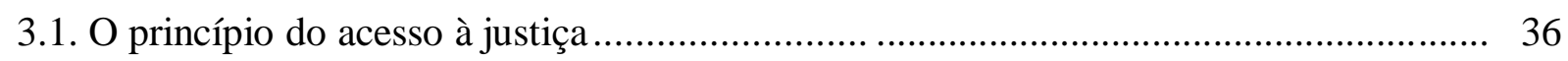

3.2. Direito à efetividade da tutela jurisdicional e duração razoável do processo ................ 40

3.3. Princípios constitucionais do processo..................................................................... 42

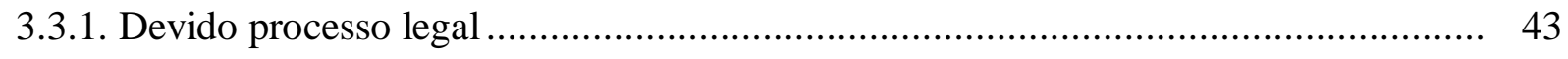

3.3.2. Princípio da igualdade e sua projeção no processo .................................................... 46

3.3.3. Contraditório e o direito à prova........................................................................... 49

3.3.4. A adequação e a adaptabilidade........................................................................ 50

3.3.5. Lealdade e boa-fé.......................................................................................... 52 


\section{CAPÍTULO II - ÔNUS DA PROVA: PANORAMA NA TEORIA GERAL PROCESSO E SUAS ESPECIFICIDADES NO PROCESSO

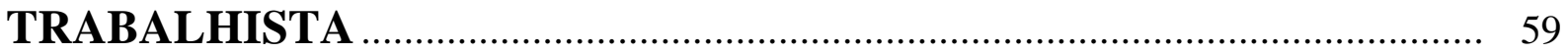

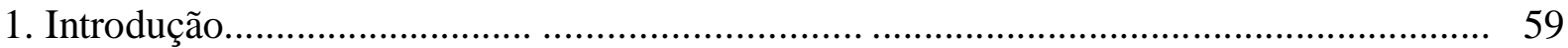

2. Ônus da prova - generalidades................................................................................. 61

3. Dupla dimensão do ônus da prova - ônus subjetivo e ônus objetivo................................. 67

4. Os poderes instrutórios do juiz................................................................................ 73

5. Positivação das regras sobre o ônus da prova no processo civil ....................................... 77

5.1. O Código de Processo Civil e a regra estática do art.333 ............................................. 77

5.2. Código de Defesa do Consumidor e a inversão do ônus da prova ................................. 82

6. As peculiaridades do ônus da prova no processo do trabalho ........................................ 86

6.1. Relativização do ônus da prova no processo do trabalho ............................................. 89

\section{CAPITULO III - TEORIA DA DISTRIBUIÇÃO DINÂMICA DO ÔNUS

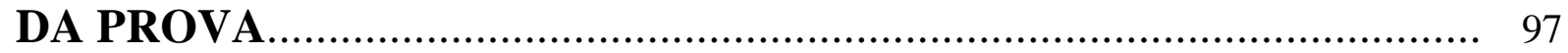

1. Considerações gerais.............................................................................................. 97

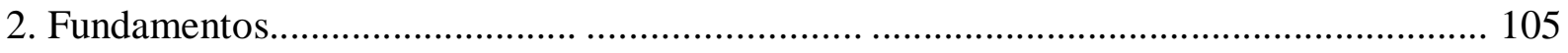

3. Críticas à doutrina do ônus dinâmico da prova ................................................................. 109

4. Campo de aplicação.................................................................................................... 111

5. Consolidação e projeção da teoria da distribuição dinâmica no direito estrangeiro .......... 112

5.1. O Código Modelo de Processos Coletivos para a Ibero-América................................. 119

6. Projeção da teoria da distribuição dinâmica do ônus da prova no direito nacional .......... 121

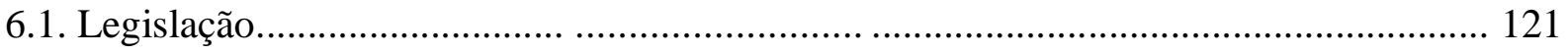




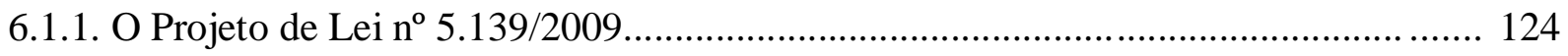

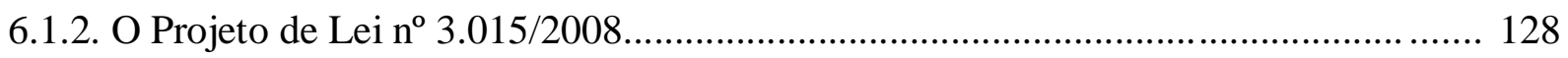

6.1.3. O Anteprojeto do Novo Código de Processo Civil - atual PLS no.166/2010 ............ 130

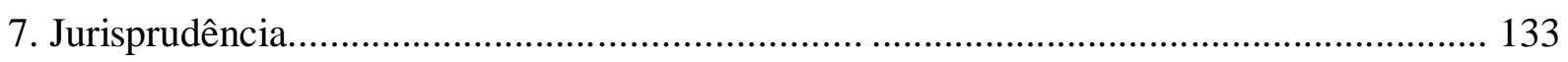

\section{CAPITULO IV - DISTRIBUIÇÃO DINÂMICA DO ÔNUS DA PROVA COMO TÉCNICA PROCESSUAL DE EFETIVIDADE DO DIREITO DO

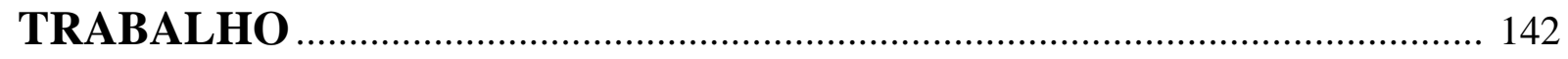

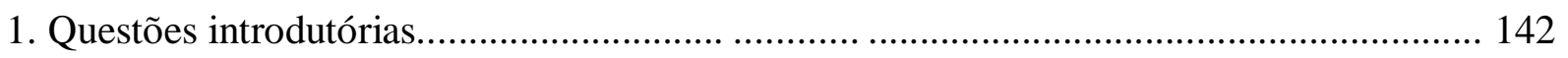

2. Processo do trabalho, efetividade e técnica processual .................................................. 147

3. Superação da técnica estática de distribuição do ônus da prova no processo do trabalho. 155

3.1. Fundamentos ou pressupostos de aplicabilidade do ônus dinâmico da prova no processo

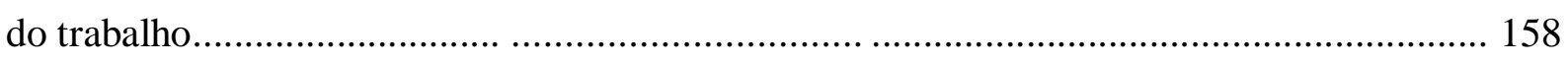

3.1.1. Observância do princípio da igualdade substancial e a aptidão para a prova ............. 159

3.1.2. Direito fundamental à prova, pré-constituição da prova, máximas de experiência e

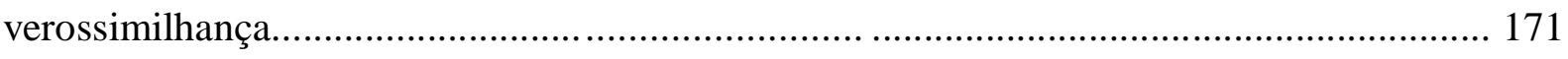

3.1.3. O princípio da proteção e o ônus dinâmico da prova ................................................... 180

3.1.4. Diretriz da lealdade, boa-fé e cooperação da partes .................................................. 187

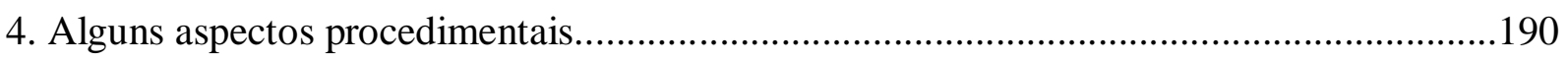

4.1. Regra dinâmica do ônus da prova - regra excepcional .............................................. 190

4.2. $\mathrm{O}$ artigo 818 da CLT - norma processual aberta.................................................... 194

5. Identificação de casos da aplicação da técnica pela magistratura trabalhista .................... 198

5.1. As recentes manifestações da jurisprudência trabalhista $\quad$.................................... 199

5.2. Os Enunciados aprovados na $1^{\text {a }}$. Jornada de Direito Material e Processual na Justiça do

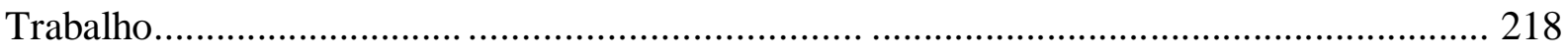


CONCLUSÃO

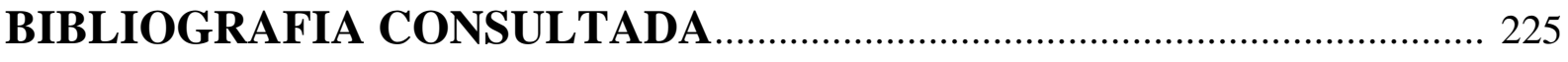

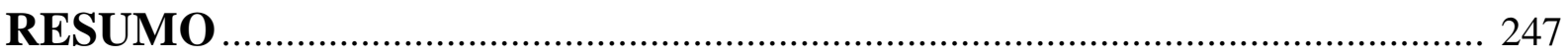

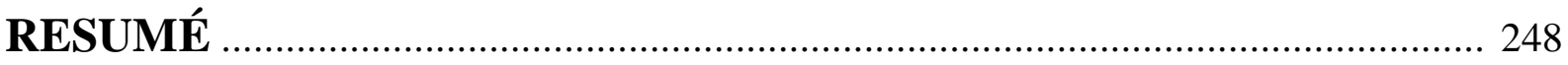

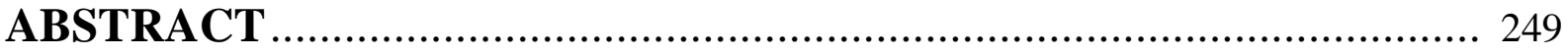




\section{INTRODUÇÃO}

\section{O TEMA A SER DESENVOLVIDO E SUAS LIMITAÇÕES}

Em que pese a Consolidação das Leis Trabalhistas contenha em seu bojo disposição específica relativa ao ônus da prova (artigo 818), os intérpretes trabalhistas não são unânimes sobre uma teoria única acerca do tema. $\mathrm{Na}$ verdade observa-se em geral na doutrina uma sistematização da matéria relativa à prova com base nas teorias processuais clássicas a luz do estatuído no Código de Processo Civil, em especial em seu artigo 333, reiteradamente invocado como necessário à complementação da regra celetista. A jurisprudência é que por vezes tem se incumbido de sumular regras de ônus da prova (e também sua inversão) derivadas em sua grande parte de presunções do que comumente ocorre na prática não apontando por vezes outros elementos sejam de ordem processual ou até mesmo constitucional que amparem tais formulações.

Assim, as reflexões neste projeto têm o escopo de analisar a questão do ônus da prova no processo trabalhista e em especial a possibilidade da recepção da teoria dinâmica do ônus da prova numa tentativa de reconstrução de uma teoria relativa ao encargo probatório estritamente relacionada com o direito material que o processo trabalhista busca efetivar.

Trata-se de um trabalho que, partindo da tutela constitucional do processo ou seja dos princípios e garantias constitucionais relativos ao direito de acesso à justiça e o direito ao devido processo legal, bem como dos pressupostos axiológicos do moderno direito processual em especial a partir das chamadas ondas renovatórias, buscará fundamentar uma sistematização do encargo probatório no processo trabalhista tentando o estabelecimento de diretrizes distributivas sem perder de vista a necessidade de promoção da igualdade processual substancial de modo a garantir a paridade de armas aos litigantes e via de consequência sua 
participação efetiva na lide, o que a legitima enquanto instrumento público democrático de acesso a justiça.

O tema em estudo, nada obstante demande a compreensão concreta da teoria geral do processo, restringir-se-á à problemática do encargo probatório, sua distribuição, inversão e seus momentos, perpassará por temas também relativos ao próprio acesso à justiça e suas dimensões.

Desta forma, nada obstante o enfoque inicial do projeto direcione-se para a sistemática constitucional de princípios fundamentais relativos ao processo, objetivando ressaltar os valores axiológicos consagrados especialmente após o advento da Constituição Brasileira de 1988 somente será levado a termo um estudo material e não organizacional da Constituição nesses aspectos como ponto de partida da estruturação lógica do trabalho. Igualmente não se pode dizer que essa análise será perfunctória, pois, repita-se, esse não é o fim proposto, mas o instrumento necessário à conclusão pretendida.

Imprescindível, pois, o estudo dos princípios constitucionais sob esse primeiro aspecto para a correta apreensão das bases jurídicas relativas ao próprio direito ao ônus da prova e sua distribuição, um dos mais importantes postulados ligados à garantia do devido processo legal.

Por fim, o ponto fulcral da análise recairá na questão da distribuição do ônus da prova a partir da teoria da carga probatória dinâmica e a formação da convicção do juiz trabalhista que em atendimento aos princípios estruturantes do acesso à justiça e do devido processo legal tem o dever constitucional de promoção da igualdade substancial das partes, impondo a utilização daqueles mecanismos para tal desiderato. Mecanismos cujos conceitos, estrutura, evolução e instrumentos, igualmente serão analisados detidamente na parte final do trabalho, permitindo o afunilamento de todas as questões postas, eis que imprescindíveis à obtenção da conclusão almejada. 


\section{JUSTIFICATIVA DA ESCOLHA E DA IMPORTÂNCIA DO TEMA}

O dia a dia da prática judicial trabalhista tem revelado a existência de limitações não legítimas à garantia constitucional de ação. São os chamados fatores perversos a que faz menção Dinamarco $^{1}$ e que residem justamente seja em imperfeições processuais e também na realidade sócio-econômica e cultural da própria sociedade.

Com efeito, a demanda trabalhista, enquanto processo judicial como qualquer outro, representa a busca de respostas a uma angústia humana. Assim, o processo trata da vida humana na sua multidiversidade e este conflito de direito material se interliga com o próprio direito processual que o atende, não podendo dele se dissociar.

A partir o esgotamento do modelo dogmático até porque o juiz é um ser vivo e não um autômato chega-se a um entendimento no sentido de que o que precisamos abordar é o conflito humano. O processo trabalhista contribuiu em muito à humanização do processo civil que evolui no sentido de um processo eqüitativo, a exemplo das reformas que têm realizado e especialmente do advento do Código de Defesa do Consumidor.

Embora se observe na esfera do direito processual do trabalho a implementação de um processo trabalhista axiologicamente fundado na defesa de valores e direitos fundamentais, na questão específica do ônus da prova tem passado despercebido o caráter dialético do processo não sendo devidamente valorizado o momento em que as partes expõem os fatos - fatos de seu conflito humano.

O processo trabalhista requer hoje uma democracia substancial não se voltando apenas para a descoberta de verdades formais e exige mais, especialmente do juiz que passa a ator ativo na promoção no princípio da igualdade processual e um dos meios para

1 DINAMARCO, Cândido Rangel. Instituições de Direito Processual Civil. Volume I. São Paulo: Malheiros, 2003, p.112. 
tanto se dá no momento destinado à prova dos fatos que fundamentam o direito material dos envolvidos.

\section{PRINCIPAIS QUESTÕES A SEREM ANALISADAS}

O presente projeto buscará, em síntese, a investigação científica da garantia da efetividade dos direitos sociais relativos aos trabalhadores através da conclusão pela necessária reformulação da questão do ônus da prova no processo trabalhista a partir da necessária adoção da teoria das cargas probatórias dinâmicas..

Partir-se-á do direito processual constitucional que traça as linhas fundamentais do processo enquanto instrumento ético, se traduzindo especialmente no direito de acesso à justiça e ao devido processo legal, para após analisarem-se questões relativas ao ônus da prova como instituto do modelo processual civil brasileiro que após a Constituição da República de 1988 passa a superar os parâmetros políticos liberais, estampados no que interesse ao objeto do trabalho, na própria regra do art. 333 do CPC.

Em complementação, objetiva-se o resgate dos princípios de direito do trabalho, em especial o princípio protecionista, reconhecendo-o com princípio fundamental, e numa adequada concepção, vinculante. Reconhecido o princípio protecionista como o princípio vetor também no processo do trabalho, a sua não observância significa a não observância do fundamento democrático da ordem jurídica justa.

Não menos importante será a apreensão do direito à prova como desdobramento do devido processo legal e como elemento de garantia constitucional de ação e da ampla defesa, dando ênfase, novamente, ao fato da ideologia constitucional alojar-se basicamente nas declarações de direitos. Isto porque, dos princípios (normas) constitucionais estabelecidos decorrem, como se pretende, os fundamentos autorizadores do redimensionamento do ônus da prova para a efetiva concretização do direito material do 
trabalhador a partir da garantia de sua igualdade substancial (e não apenas formal) no processo trabalhista.

Atenção será dada à necessária abordagem ainda que generalizada do ônus da prova no processo civil e trabalhista partindo de sua base teórica fundamental para após permear as questões relativas à natureza desse instituto e que são comuns àqueles dois ramos do direito processual, remeter às dimensões do ônus da prova e às possibilidades de sua inversão. Por fim será apresentada a teoria das cargas probatórias dinâmicas e questionada e sua aplicabilidade ao processo do trabalho.

\section{CONTRIBUIÇÃO ORIGINAL À CIÊNCIA JURÍDICA BRASILEIRA}

Pretende este projeto uma nova visão do encargo probatório no processo trabalhista assentada inicialmente nos valores constitucionais direcionados direta ou indiretamente ao processo enquanto instrumento de resolução dos conflitos materiais do trabalho e objetivamente a superação da técnica estática de distribuição do ônus probatório.

Imprescindível para essa superação a aplicação de teoria do ônus dinâmico da prova de modo que em certas hipóteses o encargo da prova tenha sua atribuição original àquela parte que tradicionalmente não o deteria, considerando-se essencialmente o direito fundamental à tutela judicial efetiva do direito material em xeque.

Considerando-se pois a moderna concepção de devido processo legal (justo), que imprescinde da igualdade substancial das partes, importa concluir que o magistrado enquanto intérprete da lei e sujeito ativo no processo tem o dever constitucional de manifestarse acerca do encargo probatório determinando-o ou invertendo-o quando presentes os tais fatores perversos externos a exemplo da hipossuficiência do trabalhador e da maior capacidade probatória do adversário. $^{2}$

\footnotetext{
${ }^{2}$ Exemplo claro seria a relativização da premissa segundo a qual o ônus da prova da prestação de serviços cabe sempre ao autor quando negada pela parte contrária. Aqui há que se perquirir em que condições esta parte contrária ingressa no processo. Por exemplo no caso de empresa tomadora de serviços, com contrato de prestação
} 
Insistir na abordagem da sistemática probatória no processo trabalhista sob uma moldagem clássica significa a manutenção do status quo patrimonial em razão da prova insuficiente de um dos sujeitos, geralmente o hipossuficiente na relação processual.

Reler o art. 818 da CLT como uma norma aberta e sob a ótica dos direitos fundamentais objetivando a efetividade processual que leva à satisfação do direito material, bem assim propor a abordagem da distribuição do ônus da prova à luz da teoria das cargas probatórias dinâmicas nos parece essencial para a concretização dos direitos sociais. Assim, propor uma visão da questão da prova e seu ônus no processo do trabalho com embasamento em teorias estreitamente vinculadas com os valores do Estado Democrático de Direito nos parece que possa trazer alguma contribuição ao direito processual do trabalho.

\section{METODOLOGIA A SER UTILIZADA}

O primeiro passo concretizado deste projeto significou uma pesquisa bibliográfica preliminar acerca do tema proposto, cujas referências se alargarão no decorrer do aprofundamento do estudo. Com efeito, os subsídios teórico-científicos dependerão do levantamento do maior número de textos doutrinários sobre as questões propostas.

Com relação aos métodos de pesquisa a opção recaiu na utilização dos métodos indutivo e dedutivo por permitirem a reflexão.

\footnotetext{
de serviços com empregadora do autor, não seria legítimo, a luz dos preceitos constitucionais, exigir apenas e tão somente daquele a prova do efetivo trabalho para a empresa contratante quando esta detém capacidade probatória dos fatos. Ou seja, tem a empresa tomadora maior capacidade probatória no particular pois mantém (ou deve manter) o controle de acesso de trabalhadores em suas dependências tendo nítida ciência das pessoas que ali trabalham ou não. Logo ao negar a prestação de serviços de determinado trabalhador tem a possibilidade da prova relativamente às pessoas que ali trabalham. E tantos outros exemplos podem ser acolhidos no dia a dia das ações trabalhistas.
} 
O método dedutivo, tradicional por excelência, com a utilização de premissas que permitam um raciocínio e conclusões lógicos, será importante na dedução inicial de modo a viabilizar a ordenação imediata das idéias.

A partir desse momento, impõe-se a utilização do método indutivo, em complementação ao primeiro, dando margem ao alargamento e amplitude da compreensão dos temas estudados.

Como os métodos não têm, considerados isoladamente, eficácia absoluta, importante o recurso ao método hipotético dedutivo que viabilizará a percepção de lacunas nos conhecimentos acerca da qual formula hipótese.

Também serão empregados como métodos de procedimento, o comparativo e o histórico o que nos auxiliará na investigação de fatos, processos e instituições do passado, sempre com vistas aos seus reflexos no presente.

Por fim e relativamente às técnicas de pesquisa será necessária a complementação da colheita de dados em textos legais, pactos internacionais, arestos jurisprudenciais (pesquisa documental) e em textos doutrinários (pesquisa bibliográfica). 


\section{CAPITULO I - PROCESSO, DIREITOS FUNDAMENTAIS E DIREITO À PROVA NA PERSPECTIVA PROCESSUAL FUNDAMENTAL}

\section{Questões introdutórias}

A possibilidade de aplicação de teoria do ônus dinâmico da prova no processo do trabalho há que partir inicialmente do reconhecimento do direito à prova e ao ônus da prova como um dos postulados inerentes à própria garantia política do devido processo legal e acesso à justiça.

Via de conseqüência a percepção da questão do ônus da prova sob um prisma adequado à concretização daqueles princípios implica, inicialmente, na necessidade da abordagem do instituto da prova e no nosso caso mais especificamente da questão da atribuição do ônus da prova sob uma perspectiva constitucional. Inicia-se, pois, o trabalho com a abordagem voltada para apreensão da evolução dos direitos fundamentais, sintetizando suas dimensões e realizando um apontamento crítico da teoria geracional, ainda que superficial, desses direitos.

Registre-se que o tratamento geracional dos direitos fundamentais pode levar à equivocada percepção da prevalência de certos direitos, ditos de primeira geração, em especial a questão dos direitos de liberdade em detrimento à realização da igualdade substancial. Ainda na primeira parte desse capítulo será abordada a questão da necessária vinculação dos direitos fundamentais de modo a amparar a conclusão final no sentido de que o juiz do trabalho está adstrito à implementação desses valores constitucionais e a aplicação obrigatória da distribuição dinâmica do ônus da prova como pretendida, o que guardará, portanto fortes traços de conformidade com a Lei Maior.

Nesse diapasão, deve-se mencionar o direito constitucional processual que traça os princípios processuais fundamentais, sendo que nessa ótica o processo hoje não é só instrumento técnico, senão e, sobretudo instrumento ético. Por isso nessa parte interessam 
especialmente a tutela constitucional do processo com breves apontamentos sobre o direito do acesso à justiça, direito ao devido processo legal, direito de ação enquanto direito fundamental, direito à efetividade da tutela jurisdicional, duração razoável do processo e os meios para a celeridade, princípio da igualdade e sua projeção no processo.

Finaliza-se este capítulo tratando do direito à prova como instituto processual substancial e promotor do processo équo ante sua dignidade constitucional.

Abordar-se-á especialmente o princípio da garantia ao devido processo legal e a questão do contraditório por tocarem profundamente ao tema em estudo. Com efeito, uma das grandes críticas à aplicação da carga probatória dinâmica guarda relação justamente com essas duas questões e somente após sua adequada compreensão poderá ser recepcionada a teoria dinâmica no direito processual do trabalho. De fato e a título de exemplo, uma das implicações dar-se-á no nível do procedimento, mais especificamente no momento adequado para que seja efetivada a distribuição do ônus da prova (durante o procedimento ou apenas no

julgamento) pois para uma parte da doutrina caso não cientificadas as partes de seus exatos encargos no momento da instrução isto poderia implicar na violação do devido processo legal e do contraditório.

Diante disso será especificamente analisado o direito constitucional à prova e ao ônus da prova.

\section{Os direitos fundamentais}

\subsection{Breve passagem histórica}

A Constituição Brasileira de 1988, marco de um Estado Democrático de Direito, e que é na verdade nosso ponto de referência quanto à possibilidade de adoção da teoria da carga dinâmica probatória no processo do trabalho, carrega em si uma nova concepção do direito brasileiro, remarcando uma das principais características do estado constitucional que é justamente à sujeição à Carta Magna de toda a legislação 
infraconstitucional e o reconhecimento, quanto ao processo, de que este é regulado pelo direito público, ainda que se debatam, em seu seio, direitos privados.

Obediência aquela que também se irradia à própria interpretação da lei pelo juiz. Nesses termos os direitos fundamentais assinalados tanto expressa quanto implicitamente na lei maior além de servir ao controle também dessa esfera do poder público igualmente representam, nas palavras de Marinoni "um arsenal destinado: (i) a conferir à sociedade os meios imprescindíveis para o seu justo desenvolvimento (direitos a prestações sociais); (ii) proteger os direitos de um particular contra o outro, seja mediante atividades fáticas da administração seja através de normas legais de proteção (direitos à proteção); (iii) estruturar vias para que o cidadão possa participar de forma direta na reivindicação dos seus direitos (direitos à participação)." (g.n.) ${ }^{3}$.

Daí a necessária referência, ainda que bem sucinta à evolução e à concepção dos direitos e princípios constitucionais, para que possamos chegar a alcançar a noção do que é para o sujeito no processo do trabalho participar efetivamente desse instrumento por meio do direito à maximização da instrução probatória, especialmente sob a ótica do ônus da prova.

A origem do que se conhece por direitos humanos pode ser encontrada na Declaração de Direitos da Virgínia, em 1776 que veio a consagrar a idéia de que todos os homens são idênticos em dignidade e direitos. Segue-se a Declaração dos Direitos do Homem e Cidadão de 1789 significou uma reafirmação e um reforço da idéia de igualdade e liberdade para todos os seres humanos.

Quanto ao nascimento dos direitos fundamentais ${ }^{4}$, alguns autores enxergam sua gênese na Carta Magna de 1215, na Ata do Habeas Corpus de 1679 e no Bill of Rights de

\footnotetext{
${ }^{3}$ MARINONI, Luiz Guilherme. Curso de Processo Civil. V.1. São Paulo: Revista dos Tribunais, 2007, p.66

${ }^{4} \mathrm{Na}$ doutrina nacional Fábio Konder Comparato vislumbra uma proto-história dos direitos fundamentais que pode ser encontrada na passagem do século XII ao século XIII, durante a Baixa Idade Média, quando se iniciaram os movimentos para a instituição de limites ao poder dos governantes e apareceram importantes documentos como a Declaração das Cortes de Leão de 1188 e a Magna Carta de 1215, de modo que este foi assim o primeiro
} 
1688 olvidando-se, entretanto que essas manifestações afirmativas não se referiam propriamente aos direitos humanos, mas simplesmente aos direitos dos ingleses, não se tratando verdadeiramente da primeira manifestação da doutrina dos direitos humanos. De fato, o constitucionalista português Joaquim José Gomes Canotilho critica essa concepção doutrinária esclarecendo que não se tratava de uma manifestação da idéia de direitos fundamentais inatos, mas da afirmação de direitos corporativos da aristocracia feudal diante do suserano. Ressalta ainda que o processo histórico não é tão linear a ponto de permitir que se marquem precisamente os momentos que contribuíram para o aparecimento e reconhecimento dos direitos fundamentais. ${ }^{5}$

Anteriormente a 1789 como leciona Manoel Gonçalves Ferreira Filho as declarações de direitos, especialmente as americanas, mais se aproximaram do modelo inglês, com demasiadas preocupações relativas aos direitos tradicionais do cidadão e olvidando-se de um tratamento mais profundo dos direitos de todos os seres humanos. ${ }^{6}$ Também José Afonso da Silva preceitua que as declarações anteriores à francesa eram limitadas no seu alcance e tendiam normalmente a diminuir a influência dos poderes monárquicos sobre a classe dominante, de modo que aquela se revela para o constitucionalista, como o marco histórico dos direitos fundamentais. ${ }^{7}$

Por seu turno, Paulo Bonavides acredita que o início da história dos direitos fundamentais remonte à declaração francesa, notando que as declarações anteriores de ingleses e americanos podiam talvez ganhar em concretude, mas perdiam espaço em abrangência, uma vez que se voltavam a uma camada social privilegiada ou a um povo ou a uma sociedade que se emancipava politicamente enquanto a declaração de 1789 tinha como destinatário todo o gênero humano. A declaração francesa está mais identificada ao caráter universal dos direitos

passo para o reconhecimento da existência de direitos comuns a todos os indivíduos, qualquer que fosse sua classe social. Esse autor aponta ainda que o segundo passo veio com a lei do Habeas Corpus de 1679 e com o Bill of Rights de 1689 , documentos que embora privilegiassem o clero e a nobreza, traziam uma formulação mais genérica e abstrata que a Magna Carta, propiciando proteção também à burguesia. In COMPARATO, Fábio Konder. A afirmação histórica dos direitos humanos. São Paulo: Saraiva, 1999. pp. 33-37

5 CANOTILHO, Joaquim José Gomes. Direito constitucional e teoria da constituição. Coimbra: Almedina, 1999. p. 356-359.

${ }^{6}$ FERREIRA FILHO, Manoel Gonçalves. Direitos humanos fundamentais. São Paulo: Saraiva, 2000, pp. 9-13. 
fundamentais, abrindo caminho para as primeiras formulações a respeito da liberdade humana. ${ }^{8}$

Independentemente de qual declaração seja a protagonista da história, fato é que a partir das declarações americana e francesa o ideário de liberdade se espalhou pelo mundo ocidental e vários textos passaram a proclamá-lo e a estabelecer garantias aos homens contra as intromissões estatais abusivas em sua esfera individual e privada, expandindo-se pelo mundo ocidental os ideais de universalidade dos direitos. Registre-se, entretanto, que a Declaração Francesa se tornou, também, o grande modelo da consagração dos direitos fundamentais e prova disso se revelaria na futura Declaração Universal dos Direitos Humanos de 1948 e na Constituição Francesa em vigor.

Essas declarações ainda que diferentes como visto estavam baseadas na idéia de um Estado individualista-burguês: o poder público figura como simples garantidor dos direitos fundamentais assegurados. Representavam cada qual com suas peculiaridades, o surgimento da democracia moderna com a substituição dos fundamentos de legitimidade do poder político, ensejando o surgimento de um Estado democrático, no qual o respeito pela liberdade individual era essencial para a quebra de privilégios estamentais típicos do Ancien Régime.

Assim a concepção inicial dos direitos fundamentais está intrinsecamente ligada à consagração da doutrina liberal, o que explica a grande valorização da liberdade de ação na esfera privada e a criação de direitos de resistência contra o poder estatal. Via de conseqüência a organização do Estado deveria estar voltada para a proteção dessa mesma esfera privada, existindo um espaço, institucionalmente garantido, onde o Estado não deveria imiscuir-se, sob pena de desrespeitar seu papel político.

Talvez por tal razão seja possível considerar como o segundo momento da afirmação dos direitos humanos fundamentais a sua constitucionalização, ou seja, a

\footnotetext{
${ }^{7}$ SILVA, José Afonso da. Curso de direito constitucional positivo. São Paulo: Malheiros, 2005, pp. 150-160.
} 
positivação em nível constitucional destes direitos a fim de que sejam dotados de efetividade. A constitucionalização dos direitos humanos vem, portanto, a viabilizar sua defesa diante de lesões ou ameaças e passa a ser a garantia que as declarações não podiam conferir aos indivíduos.

Registre-se que nesta primeira etapa não alcançaram os direitos fundamentais a plena concreção, voltando-se naturalmente para a classe burguesa no poder e não se propondo, pois, a realizar efetivamente os anseios humanos gerais de liberdade e dignidade. Entretanto pode-se dizer que nessa época já ser firmara a base sobre a qual seria construída a universalidade concreta dos direitos fundamentais, disseminando três princípios fundamentais: liberdade, igualdade e fraternidade.

Os direitos humanos fundamentais associados à primeira geração são decorrência das lutas pelas garantias de liberdade do ser humano em contraposição ao poder absoluto dos governantes. Dizem respeito, sinteticamente, à pretensão humana de limitação do poder político e de existência de uma esfera privada de atuação para cada um dos membros da sociedade, o que levaria à concepção moderna do Estado democrático fundado no individualismo e na ausência de intervenção estatal, com a adoção de um sistema representativo de alienação do poder. Nesta primeira geração, portanto, consagra-se a liberdade negativa, ou seja, liberdade significa não intromissão estatal na esfera privada do indivíduo ou do grupo. Revelam desta forma a característica de serem oponíveis ao Estado, traduzindo faculdades aos indivíduos e valorizando o homem como ser singular com liberdades abstratas. ${ }^{9}$

Na lição de Joaquim José Gomes Canotilho os direitos fundamentais de primeira geração construíram sobre o individualismo possessivo, objetivando a promoção e proteção da autonomia privada, de modo que se caracterizam como direitos de defesa do cidadão contra o Estado, ao qual não é permitida a invasão da esfera de atuação reservada ao indivíduo. Para o mestre português, de tal concepção resulta que o modelo dos direitos de

\footnotetext{
${ }^{8}$ BONAVIDES, Paulo. Curso de direito constitucional. São Paulo: Malheiros Ed., 1998, pp. 516.
} 
primeira geração é essencialmente econômico, voltado para a preservação da propriedade, traduzido no fato dos direitos do indivíduo se autodeterminarem através da livre disposição sobre a sua pessoa e os seus bens. O ser humano individualmente considerado tem garantida portanto uma ampla margem de atuação limitada exclusivamente pelo direito dos demais membros da sociedade. ${ }^{10}$

Já se reconhece, nesse momento, o princípio do devido processo legal.

No decurso da evolução histórica e em outras formas de organização do Estado, a positivação dos direitos fundamentais recebeu um tratamento material diverso, a exemplo da Declaração dos Direitos do Povo Trabalhador e Explorado, de janeiro de 1918, da Constituição da República Russa do mesmo ano e da Constituição de Weimar, sendo esta última de fundamental importância à humanidade pois com seu advento o elenco dos direitos e garantias passou a sinalizar para a tentativa de criação de um Estado cujos protagonistas seriam a liberdade e o bem-estar social.

Aos direitos de liberdade outros se somariam no início do Século XX: os denominados direitos de segunda geração, ligados à proteção da igualdade e de caráter basicamente socioeconômico. Surgiram esses direitos, conforme leciona Joaquim José Gomes Canotilho como decorrência principalmente da luta de classes e a expansão das teorias socialistas que trouxeram a lume a unidimensionalidade dos direitos de liberdade típicos do individualismo e a necessidade de completá-los ou, até mesmo, substituí-los por outros, correspondentes ao homem visto na perspectiva de sua integralidade. ${ }^{11}$

O espaço para a emancipação dos indivíduos em relação aos grupos sociais foi aberto pelas declarações de direitos da América do Norte e da França, sob a égide de um Estado liberal cuja garantia dos indivíduos vinha pela lei e pela igualdade de todos perante a mesma. Tratando-se de uma igualdade formal e não real, não foi suficiente para evitar abusos

\footnotetext{
${ }^{9}$ Idem. Ibidem pp. 517-518.

${ }^{10}$ CANOTILHO, Joaquim José Gomes. op. cit. p. 360.
} 
especialmente em relação aos trabalhadores, considerados no contrato em patamar de igualdade com os empregadores (capitalistas), com total liberdade de ajustar salários e condições de trabalho. Tal concepção que gerava, no caso, um acirramento da própria a desigualdade real, redundou na pauperização dos trabalhadores, levando mesmo à sua organização para formular exigências para melhores condições de vida. ${ }^{12}$

O principal fato histórico que permitiu o aparecimento dos direitos fundamentais de segunda geração foi, portanto, a chamada questão social que se originou em virtude de péssimas condições de vida da classe trabalhadora no final do século XIX e início do século XX; circunstâncias, essas, que inclusive facilitaram a adesão da população aos movimentos revolucionários de massa.

O momento culminante do reconhecimento da importância dos direitos humanos fundamentais veio com o advento da Declaração Universal dos Direitos Humanos datada de 1948 e que teve o mérito de tornar indiscutível a universalidade desses direitos, inserindo-os definitivamente no patrimônio jurídico da humanidade.

A terceira geração dos direitos humanos vem com os direitos de solidariedade e dizem respeito às questões de convívio dos seres humanos no mundo. Para Paulo Bonavides esses direitos decorrem da própria consciência de que o mundo está dividido entre nações desenvolvidas e subdesenvolvidas ou ainda em fase de desenvolvimento e da necessidade de superar tal estado de coisas. Logo, revelam-se como direitos fundados no dever de solidariedade e imbuídos de alto grau de humanismo e universalidade, não sendo restritos à proteção dos interesses de um indivíduo ou de um grupo mas à proteção do próprio ser humano como valor máximo da existência concreta. Trata-se ainda de direitos nascidos de reflexões relativas à paz no mundo, da necessidade de que todas as nações se desenvolvam, da

\footnotetext{
${ }^{11}$ Idem. Ibidem, pp. 361-362.

${ }^{12}$ COMPARATO, Fábio Konder. op. cit. p. 41.
} 
preocupação com o meio ambiente, hoje e no futuro, e também objetivam a proteção do patrimônio comum da humanidade. ${ }^{13}$

Os direitos da primeira, da segunda e da terceira gerações criaram o ambiente propício para uma nova concepção de universalidade dos direitos humanos fundamentais, mais abstrata e abrangente que aquela concepção oriunda da Declaração Francesa de 1789. Esta contemporânea universalidade os colocou em maior grau juridicidade, concretude, positividade e eficácia, não desprezando os direitos de liberdade, mas antes, fortalecendo-os de modo a melhor concretizá-los por meio da efetivação dos pressupostos de igualdade e fraternidade. ${ }^{14}$

Sobre os direitos fundamentais de terceira geração Joaquim José Gomes Canotilho ensina, ainda, que os mesmos pressupõem o dever de colaboração ativa de todos os Estados, vislumbrando-os como direitos que procuram proteger a paz, a autodeterminação dos povos, o patrimônio da humanidade cultural e socialmente considerado, o estabelecimento de um meio ambiente saudável e sustentável, a livre comunicação entre os povos e o desenvolvimento das nações. ${ }^{15}$

Percebe-se dessas gerações de direitos que estes se encontram ainda em evolução, tendo nascido voltados ao individualismo, e posteriormente a direitos relacionados com a proteção de categorias para por fim atingir o estágio avançado de direitos de titularidade difusa. Esta ampliação subjetiva da titularidade dos direitos fundamentais aponta para a inexistência da possibilidade de se reconhecer qualquer outra geração, sempre tendo em mente a indivisibilidade desses direitos e sua necessária complementariedade. De fato, a liberdade individual não se realiza totalmente sem a observância da igualdade, e estes somados dentro de uma realidade, para se concretizarem também necessitam dos direitos de solidariedade. Para Sérgio Resende de Barros considerada a realidade histórica, essas gerações de direitos

\footnotetext{
${ }^{13}$ Idem. Ibidem, p. 522-523.

${ }^{14}$ BONAVIDES, Paulo. op. cit. 526.

${ }^{15}$ CANOTILHO, Joaquim José Gomes. op. cit. p. 362.
} 
revelam a evolução contínua no implemento das condições de realização pessoal de todo e cada ser humano. ${ }^{16}$

Registre-se por oportuno que a narrativa seguindo o enfoque geracional é tão somente questão de didática, decorrente do próprio histórico dos direitos fundamentais, não significando preponderância de uma geração sobre a outra. Cançado Trindade inclusive critica a concepção geracional afirmando que na realidade esse pressuposto de que a ordem é a de direitos individuais e na seqüência direitos econômico-sociais e por fim o direito de coletividade corresponde na verdade à evolução do próprio direito constitucional, no plano interno dos países, vez que no plano internacional o reconhecimento dos direitos econômicos e sociais se deu em primeiro lugar, a exemplo do próprio reconhecimento do direito ao trabalho e às condições de trabalho estampado na Declaração Universal dos Direitos Humanos. Em segundo lugar afirma o autor o perigo de realizar esse tipo de distinção vez que passa a impressão de gerações de direitos substituindo as anteriores e não a noção de acumulação e expansão de direitos. Por fim, e sob o ponto de vista jurídico, também é manifestada a irresignação do autor na medida em que tem causado danos à humanidade vez que tal visão tem conferido uma maior validade aos direitos civis e políticos do que aos direitos econômicos, sociais e culturais, por vezes considerados apenas programáticos e de realização progressiva. Alerta que em razão da aplicação do enfoque geracional tem-se verificado condenação absoluta quanto se trata de violações a direitos civis e políticos e uma tolerância ímpar quanto se trata, por exemplo, de ofensas ao salário, à renda etc. ${ }^{17}$

Esta síntese histórica permite concluir que os direitos fundamentais variam em face da ideologia e das modalidades de Estado, assim como se sujeitam aos valores e princípios de uma ordem constitucional. Entretanto, sua essência revela-se na valorização do ser humano, universalmente considerado. São direitos que apontam para a existência de uma igualdade inerente a todos os seres humanos; igualdade essa que nasce como uma exigência de

\footnotetext{
${ }^{16}$ BARROS, Sérgio Resende de. Direitos humanos: paradoxo da civilização. Belo Horizonte: Del Rey, 2003. pp. 464-465.

${ }^{17}$ TRINDADE, Antônio Augusto Cançado. Cançado Trindade questiona a Tese de "Gerações de Direitos Humanos" de Norberto Bobbio. $\quad$ Disponível em www.dhneto.org.br/direitos/militantes/cancadotrindade/cancado_bob.htm, acesso em 13\12\2005.
} 
idêntico grau de proteção da dignidade própria a todos os homens pelo simples fato de pertencerem ao gênero humano.

Conquanto sujeitos a variações ideológicas ou políticas, os direitos fundamentais consagrados nas sucessivas declarações ou Constituições modernas correspondem basicamente às aspirações próprias do ser humano, que nascem da busca constante pela concretização de sua dignidade.

Registre-se por fim a exata colocação de Ingo Sarlet a propósito do significado dos direitos fundamentais na Constituição de um Estado Democrático e Social de Direito:

"No âmbito de um Estado social de Direito - e o consagrado pela nossa evolução constitucional não foge à regra - os direitos fundamentais sociais constituem exigência inarredável do exercício efetivo das liberdades e garantia da igualdade de chances (oportunidades), inerentes à noção de uma democracia e um Estado de Direito de conteúdo não meramente formal, mas, sim, guiado pelo valor da justiça material". 18

Portanto, somente com a busca da concretização dos direitos fundamentais dos trabalhadores através de meios processuais adequados a exemplo do ônus dinâmico da prova, estaríamos mais próximos da garantia da igualdade de chances.

\subsection{Noção, funções e dimensões dos direitos fundamentais}

Não sendo a proposta deste trabalho a conceituação dos direitos fundamentais pela óbvia amplitude do tema, aproveito-me da feliz síntese que Artur Carpes apresenta acerca da noção dos direitos fundamentais à qual transcrevo pela sua pertinência:

"Direitos fundamentais são aqueles que 'criam os pressupostos básicos para uma vida na liberdade e na dignidade humana'. São os direitos inerentes 'à própria noção dos direitos básicos da pessoa, que constituem a base jurídica da vida humana no seu atual nível de dignidade'. Intrínseca à noção de

\footnotetext{
${ }^{18}$ SARLET, Ingo Wolfgang. A eficácia dos direitos fundamentais. Porto Alegre: Ed. Livraria do Advogado, 2005, p.72
} 
direitos fundamentais está sua "fundamentalidade" que aponta para a especial dignidade e proteção de tais direitos em um sentido formal e material. À luz do direito constitucional pátrio, revela-se inviável a sustentação da concepção segundo a qual os direitos fundamentais formam um sistema em separado e fechado no contexto da Constituição. O conceito materialmente aberto de direitos fundamental consagrado no art. $5^{\circ}$. , $\S 2^{\mathrm{o}^{19}}$, da Constituição aponta para a existência de 'um sistema dos direitos fundamentais aberto e flexível, receptivo a novos conteúdos e desenvolvimentos, integrado ao restante da ordem constitucional, além de sujeito aos influxos do mundo circundante." 20

Os direitos fundamentais cumprem determinada função dentro do sistema político, cuja referência é o próprio texto constitucional. O modelo funcionalista dos direitos fundamentais e a função pública e política que cumprem supõem que os mesmos são normas que fundamentam competências para a participação livre de seus titulares no processo político, de tal sorte que o direito fundamental de que se trate é sempre e essencialmente um direito ou liberdade para realizar determinadas atuações e por isso a dimensão objetiva dos direitos fundamentais consiste precisamente em sua função como garantia do processo democrático. Desta forma, os direitos fundamentais se ligam a interesses primordiais da sociedade, imprescindíveis à convivência e à proteção da dignidade da pessoa humana, funcionando concomitantemente como diretriz e limite aos poderes estatais.

Ainda sob a perspectiva objetiva pode-se dizer que os direitos fundamentais então serão determinantes dos princípios e valores que orientarão todo o ordenamento jurídico, inclusive seus intérpretes e integrantes dos poderes legislativo, executivo e judiciário. ${ }^{21}$ Nessa função objetiva, portanto, informam quais serão os valores consagrados que presidirão seja a interpretação seja a aplicação da ordem jurídica ${ }^{22}$.

19 Constituição da República Federativa do Brasil - Art. $5^{\circ}$ - Todos são iguais perante a lei, sem distinção de qualquer natureza, garantindo-se aos brasileiros e aos estrangeiros residentes no País a inviolabilidade do direito à vida, à liberdade, à igualdade, à segurança e à propriedade, nos termos seguintes: (...) $\S 2^{\circ}$ - Os direitos e garantias expressos nesta Constituição não excluem outros decorrentes do regime e dos princípios por ela adotados, ou dos tratados internacionais em que a República Federativa do Brasil seja parte.

${ }^{20}$ CARPES, Artur Thompsen. Prova e Participação no Processo Civil: Dinamização dos ônus probatórios na perspectiva dos direitos fundamentais. Tese (Mestrado), Faculdade de Direito, Universidade Federal do Rio Grande do Sul, 2008, p.38.

${ }^{21}$ MARINONI, Luiz Guilherme. Curso de Processo Civil. V.1. São Paulo: RT, 2007, p.69.

${ }^{22}$ DIDIER JR, Fredie. Curso de Direito Processual Civil vol.1. Salvador: Juspodivm, 2010, p.36 
Por outro lado a dimensão subjetiva dos direitos fundamentais liga-se à ideia de garantia dos direitos subjetivos correspondendo à dimensão clássica ligada a uma perspectiva filosófico-teórica de conotação liberal. Nessa dimensão a ideia prevalente cingese à proteção do sujeito em face do Estado primordialmente para a defesa de direitos de liberdade. A partir dessa concepção aos indivíduos é permitido exigir dos poderes públicos comportamentos positivos ou omissivos.

A partir da dimensão subjetiva portanto os direitos fundamentais atribuem "posições jurídicas de vantagem a seus titulares"23.

No Brasil, mesmo que a Constituição não o expresse textualmente, a opção realizada foi tendencialmente, como ensina Luís Virgílio Afonso da Silva, por uma teoria democrático-funcional dos direitos fundamentais, de modo que estes não traduzem unicamente direitos individuais em face dos abusos estatais, mas antes elementos edificantes de uma ordem democrática e em razão disso não estão totalmente à mercê de seus titulares. ${ }^{24}$

E essa noção funcionalista que se encontra subjacente no sistema constitucional é que nos permitirá acolher a teoria do ônus dinâmico da prova sob uma perspectiva mais funcional que ontológica, reconhecendo-a como fator chave para a defesa dos direitos sociais e também como requisito para a configuração de um tipo de Estado que se pretenda democrático. Essa concepção funcionalista explica para os propósitos deste trabalho como as regras de distribuição do ônus da prova concebidas nos estreitos limites legalistas e positivistas (art.333 do CPC) se forem aplicadas contemporaneamente sem o questionamento quanto à desigualdade das partes atentam contra a nossa lei maior. E, partindo ainda dessa concepção ao adotarmos a dinâmica do ônus da prova estaremos ganhando em conteúdo, de

\footnotetext{
${ }^{23}$ Idem. Ibidem. p.36

${ }^{24}$ SILVA, Luís Virgílio Afonso da Silva. A Constitucionalização do Direito. Os direitos fundamentais nas relações entre particulares. Tese (Livre Docência), Faculdade de Direito, Universidade de São Paulo. São Paulo, 2004, p.166
} 
modo a expandir o processo do trabalho no compasso de um verdadeiro Estado social e democrático de direito.

As perspectivas objetivas e subjetivas não se sobrepõem. Ao contrário convivem, sendo que na verdade a complexidade dos próprios direitos fundamentais não pode se limitar a uma única ordem de valores, mas antes de tudo devem ser vistos na perspectiva de sua "multifuncionalidade". 25

Para tanto e a partir da divisão então proposta por Ingo Sarlet teremos dois grandes grupos para os direitos fundamentais a saber, os direitos de defesa e os direitos a prestações, interessando-nos para o enfoque deste trabalho a perspectiva prestacional, cujo objetivo dentre outros, corresponde a fazer com que o poder público disponibilize os meios materiais e humanos aptos à implementação fática do exercício das liberdades e garantias fundamentais. À sociedade torna-se possível a partir do reconhecimento dos direitos às prestações a exigência de uma postura proativa do Estado em todas as suas esferas, inclusive no que pertine à própria implementação de procedimentos processuais e conferência de possibilidades de participação aos indivíduos nesses mesmos procedimentos de modo a conduzir à efetividade da própria prestação jurisdicional e proporcionar concomitantemente respostas adequadas aos casos concretos conflituosos levados à frente do Poder Judiciário. E essa resposta deverá ser dada de forma mais ampla e adequada possível para a consecução dos

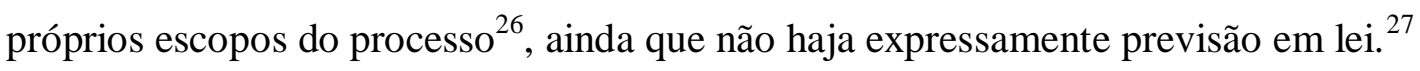

Aqui se chega mesmo a penetrar nas questões ligadas à efetividade e às técnicas processuais que a assegurem o que será abordado mais especificamente no último

\footnotetext{
${ }^{25}$ MARINONI, Luiz Guilherme; Ob.cit., p.73

${ }^{26}$ Ao tratar do escopo do processo José Roberto dos Santos Bedaque afirma que "a atuação do direito substancial é o escopo do processo" e para este "como instituto fundamental do direito processual, em primeiro lugar está o interesse da coletividade, já que sua finalidade é a realização do direito e da paz social.(...) Ele é um instrumento de atuação da própria Constituição, cuja regras abstratamente formuladas e que representam direitos e garantias fundamentais, concretizam-se processualmente”. In BEDAQUE, José Roberto dos Santos. Poderes instrutórios do juiz. São Paulo: Revista dos Tribunais, 2001, p.68-69

${ }^{27}$ Aqui estamos a nos referir expressamente à possibilidade de aplicação da dinamização do ônus da prova ainda que não esteja tal possibilidade prevista em lei. Fato que está prestes a se alterar diante do estágio avançado em
} 
capítulo. Cumpre, entretanto fazer neste tópico expressa referência à lição de Marinoni no sentido de que "há que entender que o cidadão não tem simples direito à técnica processual evidenciada na lei, mas sim direito a um comportamento judicial que seja capaz de conformar a regra processual com as necessidades do direito material e dos casos concretos. É óbvio que não se pretende dizer que o juiz deve pensar o processo civil segundo seus próprios critérios. O que se deseja evidenciar é que o juiz tem o dever de interpretar a legislação processual à luz dos valores da Constituição Federal. Como esse dever gera o de pensar o procedimento em conformidade com as necessidades do direito material e da realidade social, é imprescindível ao juiz compreender as tutelas devidas ao direito material e perceber as diversas necessidades da vida das pessoas." 28

Retomando a questão dos direitos à prestação, ${ }^{29}$ estes são próprios da segunda geração ou dimensão dos direitos humanos na linha evolutiva do Estado de Direito como atrás referido e estão presentes na maior parte das Constituições ocidentais, sendo, sem sombra de dúvida atualmente recepcionados pela Constituição da República Brasileira de 1988 tendo como exemplo de um de seus expoentes o próprio direito de acesso à justiça (art. $5^{\circ}, \mathrm{XXXV)}$ dentre outras previsões inclusive implícitas.

Os direitos de prestação tomados em sentido amplo envolvem os direitos de proteção e de participação na organização e procedimento e objetivam, inicialmente, a proteção da liberdade e igualdade. De particular relevância estes últimos os quais representam justamente a dimensão organizacional e procedimental dos direitos fundamentais. Ingo Sarlet inclusive parte do reconhecimento de que existe uma ligação íntima entre organização, procedimento e direitos fundamentais, entendendo haver uma "influência recíproca entre as três categorias, no sentido de que, se os direitos fundamentais são, de certa forma, dependentes

que se encontra o Anteprojeto do Novo Código de Processo Civil, o qual prevê explicitamente a possibilidade de aplicação do ônus dinâmico da prova como se verá no Capítulo III.

28 MARINONI, Luiz Guilherme. A antecipação da tutela. São Paulo: Malheiros, 2004, p.244

${ }^{29}$ Como bem lecionam Marinoni e Arenhart, "o Estado social fez com que os direitos fundamentais passassem a ser vistos também com o direito a prestações, que então foram classificados como direitos: (i) a prestações sociais, (ii) a prestações de proteção e (iii) a prestações destinadas a viabilizar a participação no poder e na organização social”. Continua o autor a propósito do direito de ação: “...nesse caso a participação não é 
da organização e do procedimento, sobre estes também exercem uma influência que, dentre outros aspectos, se manifesta na medida em que os direitos fundamentais podem ser considerados como parâmetros para a formação das estruturas organizatórias e dos procedimentos, servindo, para além disso, como diretrizes, para a aplicação e interpretação das normas procedimentais." 30

Nesse sentido também Artur Carpes que a partir das lições de Canotilho afirma a "existência de uma 'relação recíproca de interdependência relacional entre direitos fundamentais (direito material) e procedimento (direito procedimental e processual)'. Portanto, não apenas a 'organização e o procedimento, nas suas repercussões sobre o direito material, devem ser perspectivadas sob a luz dos direitos fundamentais", mas também "o direito material, na sua irradiação sobre a organização e procedimento não deva divorciar-se da importância do due processs para a garantia ou proteção jurídica dos direitos fundamentais". 31

Percebe-se, assim, uma íntima conexão entre direitos constitucionais e direitos processuais e via de consequiência a mesma estreita ligação entre a jurisdição e seu instrumento processual e a proteção dos direitos espelhados na Constituição. Logo, os direitos fundamentais no aspecto procedimental/organizacional revelam dimensões mais amplas que a simples conformação do processo às normas constitucionais na medida em que o que está a exigir a compreensão contemporânea é o próprio emprego das normas constitucionais no exercício da jurisdição. ${ }^{32}$

viabilizada somente pelo legislador, mas também pela jurisdição". In Curso de Processo Civil. V.2”. São Paulo:RT. 2007, pp.198-199

${ }^{30}$ SARLET, Ingo Wolfgang. op.cit. p. 213

${ }^{31}$ CARPES, Artur Thompsen. Prova e Participação no Processo Civil: Dinamização dos ônus probatórios na perspectiva dos direitos fundamentais. Tese (Mestrado), Faculdade de Direito, Universidade Federal do Rio Grande do Sul, 2008, p.241.

${ }^{32}$ OLIVEIRA, Carlos Alberto Álvaro O processo civil na perspectiva dos direitos fundamentais. Disponível em http://www.abdpc.org.br/abdpc/artigos/Carlos\%20A\%20A\%20de\%20Oliveira(6)\%20-\%20formatado.pdf. Último acesso em 10/12/2010. 
Partindo-se de premissas relativas à força normativa da Constituição, da supremacia e caráter principiológico do direito fundamental Carlos A. A. Oliveira magistralmente delimita a questão:

"Do ponto de vista do direito processual, impõe-se sublinhar que os direitos fundamentais, para poderem desempenhar sua função na realidade social, precisam não só de normatização intrinsecamente densificadora como também de formas de organização e regulamentação procedimentais apropriadas. Daí a necessidade de estarem assegurados constitucionalmente por normas, principiais ou não, garantindo-se ao mesmo tempo seu exercício e restauração, em caso de violação, por meio de órgãos imparciais com efetividade e eficácia. Embora essa dimensão procedimental nem sempre se refira ao processo judicial, também o abrange, a evidenciar uma interdependência relacional entre direitos fundamentais e processo.

Faceta importante a ressaltar é que a participação no processo para a formação da decisão constitui, de forma imediata, uma posição subjetiva inerente aos direitos fundamentais, portanto é ela mesma o exercício de um direito fundamental. Tal participação, além de constituir exercício de um direito fundamental, não se reveste apenas de caráter formal, mas deve ser qualificada substancialmente.

Isso me leva a extrair do próprio direito fundamental de participação a base constitucional para o princípio da colaboração, na medida em que tanto as partes quanto o órgão judicial, como igualmente todos aqueles que participam do processo (serventuários, peritos, assistentes técnicos, testemunhas etc.), devem nele intervir desde a sua instauração até o último ato, agindo e interagindo entre si com boa-fé e lealdade". 33

A partir da idealização dos direitos fundamentais como destinados a proporcionar o bem-estar da sociedade, exprime-se como constatação lógica uma exigência no sentido de que para a efetividade dos mesmos seja imprescindível o reconhecimento da importância daquela dimensão procedimental que se afigura, portanto, como garantidora da existência de meios jurídico-processuais aptos a amparar também a própria prestação jurisdicional.

\footnotetext{
${ }^{33}$ Idem.Ibidem. Importante lição extrai-se ainda desse mesmo ensaio de Carlos Antonio Álvaro de Oliveira no sentido de que "(...) a participação no processo e pelo processo já não pode ser visualizada apenas como instrumento funcional de democratização ou realizadora do direito material e processual, mas como dimensão intrinsecamente complementadora e integradora dessas mesmas esferas. O próprio processo passa, assim a ser meio de formação do direito, seja material, seja processual. Tudo isso se potencializa, quando se atenta em que o processo deve servir para a produção de decisões conforme a lei, corretas a esse ângulo visual, mas, além disso, dentro do marco dessa correção, presta-se essencialmente para a produção de decisões justas".
} 
Igualmente como corolário dessa ordem de idéias o juiz contemporâneo tem como uma de suas tarefas e dentro dessa perspectiva dos direitos prestacionais proceder quando necessário à adequação de procedimentos para dar azo aos reclamos constitucionais de efetividade dos próprios direitos materiais fundamentais de modo a concretização dos valores ápice da sociedade em que se insere.

\subsection{Eficácia dos direitos fundamentais - aplicabilidade e vinculação}

Ainda em relação aos direitos fundamentais importa realizar um breve apontamento sobre a questão de sua eficácia desta feita sob o prisma especial da necessária vinculação do juiz à sua realização por meio da adequação do procedimento à realização dos princípios e valores indicados pela Constituição.

A eficácia dos direitos fundamentais subdivide-se em eficácia vertical e eficácia horizontal. A primeira tem a ver justamente com a necessária obediência pelos poderes públicos (legislador, juiz, administrador) dos ditames da lei maior seja na edição de leis, na prolação de decisões jurisdicionais e nas práticas administrativas. Aqui o respeito aos direitos fundamentais dos cidadãos impera como regra mandamental. A eficácia horizontal refere-se a tema mais polêmico, ou seja, à chamada vinculação dos direitos fundamentais aos particulares, discutindo-se aqui qual a "medida" da esfera da autonomia privada de cada indivíduo.

Essa nova ordem de pensar a eficácia dos direitos fundamentais vem na esteira da transformação da sociedade e decorre especialmente do advento estado social. A vinculação vertical tinha em mente a proteção ao cidadão como preconizada pelo Estado Liberal; já a vinculação horizontal parte do reconhecimento de que as pessoas, em suas relações particulares, também podem mostrar um grau forte de desigualdade material que deixa uma das partes à mercê da outra como ocorria com o indivíduo frente ao poder público. As relações trabalhistas bem demonstram como a desigualdade material pode influir nas 
relações jurídicas seja de emprego ou de trabalho. Também será um dever do Estado proteger um cidadão frente ao outro.

O Direito do Trabalho constitui, talvez, o ramo do direito privado no qual, pela primeira vez, os direitos humanos fundamentais demonstraram possuir aplicabilidade às relações estabelecidas entre particulares e baseadas no princípio da autonomia da vontade. Afinal, este ramo da Ciência Jurídica surge, em parte, como uma resposta aos anseios do proletariado, havendo, pois, quem o concebesse como um direito da classe trabalhadora em face do capital.

Para Daniel Sarmento, os sindicatos, por exemplo, são sujeitos ativos e passivos de direitos fundamentais e como atores ativos na promoção de direitos são eles próprios também vinculados, na sua relação com a categoria, aos direitos fundamentais (proteção da minoria). Continua o autor alertando que "a liberdade fundamental tutelada em primeiro plano pela Constituição não é a autonomia das entidades intermediárias, como as associações, a família e a empresa. A liberdade capital é a liberdade da pessoa. É certo que, numa sociedade pluralista, a garantia da autonomia destas instituições em face do Estado tem grande importância. Esta autonomia é tutelada porque se entende que ela é relevante para que as pessoas possam realizar os fins pessoais a que se propõem, os quais muitas vezes pressupõem o engajamento em instituições intermediárias. Mas a importância atribuída a esta autonomia associativa, cumpre repetir, tem valor instrumental em relação à liberdade e à dignidade humanas. Estas sim constituem fins em si, numa ordem constitucional que tem no seu centro de gravidade o princípio da dignidade da pessoa humana." 34

Marinoni é explícito ao afirmar a importância da incidência dos direitos fundamentais sobre as relações privadas, entendendo ser "inquestionável, por exemplo, que os direitos fundamentais têm grande importância na regulação das relações entre o empregador e o empregado, o que somente pode significar uma eficácia imediata e direita dos direitos

\footnotetext{
${ }^{34}$ SARMENTO, Daniel. Direitos fundamentais e Relações Privadas. Rio de Janeiro: Lúmen Júris, 2004, pp. 357358
} 
fundamentais sobre os privados." ${ }^{35}$ Bem a propósito a preocupação do constituinte brasileiro com os direitos trabalhistas é inequívoca a teor da imensa gama de direitos sociais positivados nos $\operatorname{artigos} 7^{\circ}$ e $8^{\circ}$ da Lei Maior.

Vislumbrando a propriedade da incidência dos direitos fundamentais a partir também do reconhecimento da desiguadade das condições humanas Daniel Sarmento afirma que

"numa sociedade em que, tal como na fazenda dos bichos de George Orwell, "todos são iguais, mas alguns são mais iguais do que os outros', proteger os 'menos' iguais dos 'mais' iguais tornou-se uma das principais missões dos direitos fundamentais Sob essa perspectiva, os direitos humanos deixam de ser vistos como devedores apenas do Estado, na medida em que outros atores não-estatais são convidados para o mesmo palco, chamados às suas responsabilidades para a construção de uma sociedade mais justa, centrada na dignidade da pessoa humana". ${ }^{36}$

\section{Continua o mesmo autor:}

(...) um dos fatores primordiais que deve ser considerado nas questões envolvendo a aplicação dos direitos fundamentais nas relações entre particulares é a existência e o grau de desigualdade fática entre os envolvidos. Em outras palavras, quanto maior for a desigualdade, mais intensa será a proteção ao direito fundamental em jogo, e menor a tutela da autonomia privada. Ao inverso, numa situação de tendencial igualdade entre as partes, a autonomia privada vai receber uma proteção mais intensa, abrindo espaço para restrições mais profundas ao direito fundamental com ela em conflito" 37

A questão relativa à vinculação dos particulares aos direitos fundamentais interessa à visão deste trabalho na medida em que os direitos trabalhistas e os direitos fundamentais se interpenetram também na esfera das relações processuais, tratando-se de verdadeira imposição constitucional ao juiz do trabalho que aplique as técnicas processuais próprias à equalização das partes na disputa judicial.

Atente-se como observa Wilson Steinmetz que o Estado desde há muito não é o único detentor de poder, sendo certo que no mundo contemporâneo pessoas privadas e

\footnotetext{
${ }^{35}$ MARINONI, Luiz Guilherme. op. cit., p.82

${ }^{36}$ SARMENTO, Daniel. op.cit. p. 4
} 
grupos também detêm poder político e econômico e lutam por ele. ${ }^{38}$ Assim, os direitos fundamentais que têm, dentre outras, a função histórica de limitação do poder estatal, exercem agora também esse papel face aos próprios particulares.

Com efeito, proliferam no mundo capitalista grupos econômicos, financeiros, de mídia, associações e sindicatos e até mesmo organizações criminosas, todos com alto grau de poder e barganha. Noticia Wilson Steinmetz que no Brasil além dos grupos acima, outros atores detém essa capacidade de, no seio de relações com outros particulares, impor restrições e limitações, e são exemplo disso as próprias Centrais Sindicais, o Movimento dos Trabalhadores Rurais Sem-Terra (MST), associações de consumidores etc. E, em várias oportunidades, os interesses desses sujeitos colidem com o exercício de direitos fundamentais por outros particulares. ${ }^{39}$

\section{Direitos fundamentais, processo e tutela constitucional do processo}

Partindo portanto da dupla dimensão dos direitos fundamentais temos a premissa de que as regras processuais deverão, em sua criação, adequar-se prima facie à tutela daqueles direitos de modo que a lei hoje se subordina à Constituição federal. Não há como deixar de concluir que contemporaneamente o processo é também um direito fundamental.

O direito ao processo foi inserido na Declaração Universal de 1948 nos seguintes termos: “Art. X - Toda pessoa tem direito, em plena igualdade, a uma audiência justa e pública por parte de um tribunal independente e imparcial para decidir seus direitos e deveres ou do fundamento de qualquer acusação criminal contra ele". No mesmo ano previa a Declaração Americana dos Direitos e Deveres do Homem em seu art.XVIII que "toda pessoa pode recorrer aos tribunais para fazer respeitar seus direitos. Deve poder contar, outrossim, com processo simples e breve, mediante o qual a justiça a proteja contra atos de autoridade

\footnotetext{
${ }^{37}$ Idem.Ibidem. p.303

${ }^{38}$ STEINMETZ, Wilson. A vinculação dos particulares a direitos fundamentais. São Paul: Ed. Malheiros, 2004, p.85
} 
que violem, em seu prejuízo, quaisquer dos direitos fundamentais consagrados constitucionalmente". Também em 1966 com o Pacto de Direitos Civis e Políticos restou previsto o direito da pessoa ser ouvida publicamente e com as devidas garantias por um tribunal competente, independente e imparcial (art.14). No Pacto de São José da Costa Rica em 1969 assentou-se que "toda pessoa terá o direito de ser ouvida, com as devidas garantias e dentro de um prazo razoável, inclusive quanto às questões de direitos e obrigações de caráter civil, trabalhista, fiscal ou de qualquer outra natureza.

A positivação do processo nas cartas constitucionais e nas declarações de direitos prestigia seus princípios e valores. Hoje se fala até mesmo em neoconstitucionalismo que se traduz pelo reconhecimento da força normativa da constituição, da relevância da jurisdição constitucional e de uma interpretação de todo arcabouço jurídico-processual consoante a lei maior, ou seja, as previsões constitucionais passam a orientar inclusive condutas, especialmente as dos poderes públicos. Igualmente se verifica que inúmeros institutos processuais foram positivados na Constituição Federal, levando ao denominado neoprocessualismo e aos chamados direitos fundamentais processuais que se projetam em princípios levando à busca de sua interpretação focada para a efetividade daqueles direitos.

Sob esta perspectiva de inclusão dentre os próprios direitos humanos e com a evolução do direito processual, o processo como instrumento de pleno acesso à justiça ${ }^{40}$ passou a ter uma conotação mais publicista do que privada. No atual patamar de desenvolvimento do instrumento processual este tem fins públicos, serve mesmo à legitimação de exercício de poder estatal através do procedimento que é previsto em lei e sob a garantia do due process of law.

\footnotetext{
${ }^{39}$ Idem. Ibidem. op.cit.p. 88

${ }^{40}$ A propósito a síntese da evolução da história do processo civil em três fases, sendo certo que na primeira o processo era apenas um meio de exercício de direitos e a ação confundida com o direito material; na segunda fase tomaram espaço as teorias processuais a exemplo da natureza da ação e do processo e outros institutos, com grande preocupação no destaque do direito processual como ramo autônomo do direito. Por fim, instaurou-se a fase instrumentalista do processo a qual deu azo ao modo de compreensão do processo como instrumento de acesso à Justiça através da remarcação de sua efetividade. In CINTRA, Antonio Carlos; GRINOVER, Ada Pellegrini; DINAMARCO, Cândido Rangel. Teoria Geral do Processo. São Paulo: Malheiros, 1995
} 
Esses fins públicos se revelam inclusive, nas palavras de Cambi como “instrumento democrático do poder jurisdicional, transcendem os interesses individuais das partes na solução do litígio" 41

Orienta-se, atualmente o processo pelos princípios e valores constitucionais, acima dos interesses controvertidos, gerando reflexos em vários ramos processuais a exemplo da própria liberdade de valoração das provas. ${ }^{42}$

Na verdade serão justamente as premissas constitucionais que darão suporte ao processo de modo que há verdadeira relação de complementariedade entre o processo e a Constituição. O instrumento processual passa então a ser orientado a partir de diversas normas da Constituição Federal, tanto explícitas como implícitas, impondo-se sua estruturação para atendimento e concretização dessas normas.

Hoje já se fala em direito constitucional processual como designação de normas e princípios que vão tutelar a essência do direito processual, a exemplo do princípio de acesso justiça, direito à efetividade da tutela jurisdicional e à duração razoável do processo bem assim dos meios para a celeridade. Sob outra denominação tem-se esse fenômeno descrito como a constitucionalização do processo. ${ }^{43}$

Constitucionalização do processo, como ensina Cássio Scarpinellla Bueno “convida o estudioso a lidar com métodos hermenêuticos diversos - a filtragem constitucional de que tanto falam alguns constitucionalistas, tomando consciência de que a interpretação do direito é valorativa e que o processo como método de atuação do Estado, não tem co mo deixar

\footnotetext{
${ }^{41}$ CAMBI, Eduardo Augusto Salomão. Direito Constitucional à Prova no Processo Civil. São Paulo: Revista dos Tribunais, 2001, p.93

${ }^{42}$ Idem. Ibidem. p. 93

43 Para uma distinção conceitual entre direito processual constitucional e direito constitucional processual segue a proposta por Canotilho. Para o mestre português direito processual constitucional é "conjunto de regras e princípios positivados na Constituição e noutras fontes de direito (leis tratados) que regulam os procedimentos juridicamente ordenados à solução de questões de natureza jurídico-constitucional pelo Tribunal Constitucional" e o direito constitucional processual "tem como objecto o estudo dos princípios e regras de natureza processual positivados na Constituição e materialmente constitutivos do status activus processualis no ordenamento
} 
de ser, em igual medida, valorativo, até como forma de realizar adequadamente aqueles valores, no e pelo processo. A dificuldade reside em identificar adequadamente estes valores e estabelecer parâmetros os mais objetivos possíveis para que interpretação e aplicação do direito não se tornem aleatórias, arbitrárias e/ou subjetivas. A neutralidade científica de outrora não pode, a qualquer título, ser aceita nos dias atuais". ${ }^{4}$

\subsection{O princípio do acesso à justiça}

A partir da conformação do Estado Democrático de Direito ou também chamado Estado Constitucional, passa-se a ter preocupação focada na construção de uma sociedade mais justa a partir principalmente da correção das desigualdades sociais, sendo que um dos problemas visualizados passa a ser não só configurar os direitos sociais como direitos humanos, mas garanti-los; constatação que leva a uma maior importância conferida ao processo como instrumento de defesa inclusive desses direitos. ${ }^{45}$

Aliás o acesso à justiça se mostrou como um aspecto central do welfare state, não se limitando apenas à justiça na sua conotação de prestação jurisdicional. Como ensina Mauro Cappelletti o movimento de acesso à justiça sinalizou para reivindicações profundas a exemplo do próprio acesso ao trabalho, à saúde, educação. ${ }^{46}$

Não é por outra razão que Canotilho trata da garantia de acesso aos tribunais como forma de concretização do princípio estruturante do Estado de Direito. ${ }^{47}$

Assim o acesso à justiça está na ordem do momento, mas conceituá-lo não é tarefa muito fácil ${ }^{48}$. Passemos à sua positivação no ordenamento constitucional.

constitucional português" CANOTILHO, Jose Joaquim Gomes. Direito constitucional e teoria da Constituição. 3. ed. Coimbra: Almedina, 2002, pp.957-958

44 BUENO, Cássio Scarpinella. Curso sistematizado de direito processual civil: teoria geral do direito processual civil. vol.1. São Paulo: Saraiva, 2007, p.71

${ }^{45}$ LEITE, Carlos Henrique Bezerra. O acesso à Justiça como Direito Humano e Fundamental. Revista Trabalhista Direito e Processo. São Paulo, no. 26 - abril/junho, 2008, pp.21-28

46 CAPPELLETTI, Mauro. Processo, Ideologias e Sociedade. Vol. I [Trad] Elicio de Cresci Sobrinho. Porto Alegre: Fabris, 2008, p.386 
Entre nós este princípio máximo vem descrito no artigo $5^{\circ}$ da Constituição da República, inclusive como um de seus grandes contributos, através dos incisos XXXV e LXXIV que dispõem respectivamente que a lei não excluirá da apreciação do Poder Judiciário lesão ou ameaça a direito e que o Estado prestará assistência jurídica integral e gratuita aos que comprovarem insuficiência de recursos.

Também se vislumbra manifestação desse princípio no inciso XXXIV desse mesmo artigo $5^{\circ}$ da Lei Maior ao dispor sobre o direito de petição aos poderes públicos em defesa de direitos ou contra ilegalidade ou abuso de poder, independentemente do pagamento de taxas (justiça gratuita).

Entretanto o problema do acesso à justiça não se resume nas previsões constitucionais acima descritas, ou seja, o simples fato da garantia de acesso à jurisdição, havendo que pensá-la também sob uma dimensão substancial e não apenas formal. Dimensão esta que imprescinde do reconhecimento de que o acesso à justiça pretende-se como um acesso à ordem jurídica justa ${ }^{49}$.

A Constituição da República de 1988 garantiu o livre acesso à justiça a todos os cidadãos. E sob a ótica desse princípio, o poder judiciário se coloca como o órgão máximo de solução dos conflitos, no qual todos os cidadãos terão seus direitos individuais e sociais resguardados. A propósito José Carlos Barbosa Moreira refere-se ao acesso à justiça

${ }^{47}$ CANOTILHO, Jose Joaquim Gomes. Op.cit. p.487

${ }^{48}$ Essa dificuldade de definição fora antevista por Cappelletti e Garth ao afirmarem em obra clássica que o acesso à justiça trata-se de sistema pelo qual as pessoas podem reivindicar seus direitos e/ou resolver seus litígios sob os auspícios do Estado, sendo que o sistema deveria ser igualmente acessível a todos e produzir resultados que fossem individuais e socialmente justos. Prosseguem ainda os autores no sentido de que a premissa básica será, em sua obra a de que a justiça social como desejada por nossas sociedades modernas, pressupõe o acesso efetivo. CAPPELLETTI, Mauro; GARTH, Bryant. Acesso à Justiça. [Trad] Ellen Gracie Northfleet. Porto Alegre: Fabris, 1988, p. 8

${ }^{49}$ DINAMARCO, Cândido Rangel. Instituições de Direito Processual Civil. São Paulo: Malheiros, 2003, p.114. 
como princípio básico do ordenamento jurídico, assinalando, com base no disposto no inciso XXXV, uma tendência à universalização do exercício da função jurisdicional. ${ }^{50}$

A ordem constitucional facilita o acesso ao cidadão à Justiça o que não se limita às estruturas físicas do órgão ou ao direito de ação. O que se tem hoje compreendido como acesso à justiça implica também a concessão à sociedade de uma prestação jurisdicional eficaz e que expresse o verdadeiro significado de justiça. Sob este último prisma, Carlos Alberto Álvaro de Oliveira ao tratar de fatores externos ao formalismo processual, afirma que o valor justiça conquanto um dos fins jurídicos do processual tem relação íntima com a concretização do direito material, de modo que o processo ao servir para realização do direito material, não pode ser posto em perigo por regramentos impróprios e meramente processuais, com riscos até mesmo à igualdade das partes. ${ }^{51}$

Em síntese o acesso à justiça não se traduz apenas na possibilidade de ajuizar ação perante um órgão do poder judiciário. Pela aplicação deste princípio se exige do Estado inclusive qualidade e não só quantidade como resposta às demandas ajuizadas. Tornase imprescindível pela aplicação do princípio de acesso à justiça que se possa dar uma solução útil e satisfatória, célere e efetiva, inclusive levando a um julgamento de mérito, ou seja, sem exacerbação dos fatores que possam levar às extinções dos feitos sem apreciação da questão de fundo. Exige-se, na verdade, um exame substancial da causa pelo juiz de modo à que o provimento jurisdicional reflita realmente os valores da sociedade. ${ }^{52}$

Quem bem apontou as configurações do que hoje podemos chamar de direito de acesso à Justiça foi Kazuo Watanabe, merecendo transcrição expressa:

“a) o direito de acesso à justiça é, fundamentalmente, direito de acesso à ordem jurídica justa;

b) são dados elementares desse direito: (1) o direito à informação e perfeito conhecimento do direito substancial e à organização de pesquisa permanente a

\footnotetext{
${ }^{50}$ MOREIRA, José Carlos Barbosa. A constitucionalização do Processo no Direito Brasileiro. Estudos de Direito Processual Constitucional. São Paulo:Malheiros, 2009, pp.47-55

${ }^{51}$ OLIVEIRA, Carlos Alberto Álvaro. Do formalismo no processo civil. São Paulo: Saraiva, 2010, pp.99-100.

52 DINAMARCO, Cândido Rangel. Instituições de Direito Processual Civil. Vol. I. São Paulo:Malheiros, 2003, p.115.
} 
cargo de especialistas e orientada à aferição constante da adequação entre a ordem jurídica e a realidade socioeconômica do País; (2) direito de acesso à Justiça adequadamente organizada e formada por juízes inseridos na realidade social e comprometidos com o objetivo de realização da ordem jurídica justa; (3) direito à preordenação dos instrumentos processuais capazes de promover a efetiva tutela de direitos; (4) direito à remoção de todos os obstáculos que se anteponham ao acesso efetivo à Justiça com tais características" 53

O acesso à justiça contemporaneamente é adjetivado compreendendo-se portanto sob a premissa de um acesso à ordem jurídica justa, de forma que a própria garantia da inafastabilidade da jurisdição faz com que quaisquer restrições ao exercício de direitos processuais sejam ilegítimas. Nesse sentido amplo exige também implementação daqueles instrumentos processuais aptos à promoção à efetivação da tutela dos direito e ao próprio afastamento dos fatores adversos sejam de ordem social, econômica, dentre outros, que levem ao comprometimento do efetivo acesso à justiça. ${ }^{54}$

O repensar da regra estática do ônus da prova, como instrumento processual que é, deve nessa perspectiva de concretização dos direitos humanos mostrar-se consentâneo com o princípio de acesso à justiça, para que não impeça o livre acesso das partes à justiça em condições de igualdade no processo do trabalho. Representa a teoria do ônus dinâmico da prova, na perspectiva do acesso à justiça a garantia à obtenção de uma tutela jurisdicional efetiva e equânime ao conferir mecanismo adequado para demonstração do direito da parte em juízo. De se ver, portanto, que a teoria da carga dinâmica probatória possui forte substrato constitucional, uma vez que, calcada nos princípios acima referidos, constitui mecanismo apto a densificá-los, de forma a propiciar a concretização dos direitos em juízo, na maior medida possível.

Especificamente no tocante à Justiça do Trabalho se verificam vários obstáculos à garantia de acesso do trabalhador exigindo-se destarte para obediência à esse princípio maior a implementação de mecanismos que melhor concretizem os direitos sociais

\footnotetext{
${ }^{53}$ WATANABE, Kazuo. Acesso à justiça e sociedade moderna. In: GRINOVER, Ada Pellegrini (coord.). Participação e processo. São Paulo: RT, 1988. p.135, apud MAIOR Jorge Luiz Souto. A efetividade do processo. In: CORREIA, Marcus Orione Gonçalves (org.). Curso de direito do trabalho: vol. 4 - Direito processual do trabalho. São Paulo: LTr, 2009, p. 57
} 
envolvidos, vislumbrando-se, repita-se, na dinamização do ônus probatório um desses mecanismos de tutela.

\subsection{Direito à efetividade da tutela jurisdicional e duração razoável do processo}

Contemporaneamente a teoria geral do processo parte de algumas idéias dentre as quais a de que a lei, como vimos se subordina à Constituição, ou seja, amarra-se a esses direitos positivados na Lei Maior, que justamente lhe agregam o qualificativo substancial; dão-lhe substância, não apenas forma. Essa substanciação pelos valores constitucionais contagiou também a própria idéia sobre a jurisdição, pois o juiz também passou a ter que interpretar a norma considerando as diferenças entre as pessoas, o que na concepção apenas formal não era permitido. Assim o próprio surgimento de novos fatos sociais deu ao juiz a legitimidade para construção e reconstrução de significados aos casos já existentes ou aos novos. Abriu-se a possibilidade ao juiz de decidir o caso fazendo valer os princípios constitucionais o que se afigurou imprescindível para a prestação efetiva da tutela jurisdicional a partir das próprias necessidades do direito material envolvido.

Canotilho ao tratar do princípio de acesso ao direito e da garantia da tutela jurisdicional efetiva afirma que na Constituição portuguesa aquele primeiro foi substituído por esta última a fim de que não se garantisse apenas o acesso ao poder judiciário mas especialmente a possibilidade aos cidadãos de defender seus direitos por intermédio de um ato de jurisdição. Compreenderia esse direito à tutela jurisdicional efetiva sua concretização por meio de um processo jurisdicional equitativo. ${ }^{55}$

Na medida da evolução do pensamento processual passou-se a buscar uma maior efetividade aos procedimentos inclusive a partir da obrigação do juiz quanto à compreensão do processo e suas normas a partir do direito fundamental à tutela jurisdicional, e ao considerar essas várias necessidades do direito substancial conferir ao juiz um poder-dever

\footnotetext{
54 CAMBI, Eduardo Augusto Salomão. op.cit. p.105

${ }^{55}$ CANOTILHO, Jose Joaquim Gomes. op. cit. p.433
} 
de buscar uma técnica processual apta à tutela desse mesmo direito material. ${ }^{56}$ Essa idéia é justamente a que nos possibilita pretender a interpretação do art.818 da Consolidação das Leis do Trabalho como uma regra processual aberta, permitindo ao juiz do trabalho uma maior concreção ao direito de igualdade substancial das partes em matéria probatória, garantindo a paridade de armas aos litigantes.

O direito de ação visto também sob a ótica de um direito fundamental processual não pode ser obstaculizado, exigindo-se uma postura ativa do Estado, ou seja, que o juiz exerça sua função de forma adequada permitindo a proteção efetiva de todos os direitos levados ao seu conhecimento. Esse direito de ação compreendido a partir da Constituição traz ínsito o direito à tutela jurisdicional efetiva e à própria duração razoável do processo aos meios que lhe garantam a celeridade.

Com efeito, a tutela jurisdicional efetiva deve associar-se ainda ao pressuposto de uma duração razoável do processo. O princípio da duração razoável duração do processo restou inserido no art. $5^{\circ}$, LXXVIII, $^{57}$ da CRFB quando do advento da Emenda Constitucional de no. 45/2004, nos seguintes termos "a todos, no âmbito judicial e administrativo, são assegurados a razoável duração do processo e os meios que garantam a celeridade de sua tramitação", tratando-se também de um conceito indeterminado que impõe sua percepção ao caso concreto na medida das peculiaridades e características que envolvem o próprio direito material envolvido.

Não há um critério geral portanto que possa definir essa razoabilidade de prazo, sendo possível pensar que a demora dever ser necessária e adequada à solução do caso concreto, para concretização, inclusive de outros princípios constitucionais como do

\footnotetext{
${ }^{56}$ MARINONI, Luiz Guilherme. Curso de Processo Civil. V.1. São Paulo, Ed. RT. 2007, p.119.

${ }^{57}$ O Pacto de São José da Costa Rica do qual é signatário o Brasil já previa em seu art.8, 1: "Toda pessoa tem o direito a ser ouvida com as devidas garantias e dentro de um prazo razoável, por um juiz ou tribunal competente, independente e imparcial, estabelecido anteriormente por lei, na apuração de qualquer acusação penal formulada contra ele, ou para que se determinem os seus direitos ou obrigações de natureza civil, trabalhista, fiscal ou de qualquer outra natureza"
} 
contraditório, ampla defesa, etc. Fredie Didier Junior traz na espécie os critérios apontados pela Corte Européia dos Direitos do Homem para a satisfação do conceito de duração razoável do processo. São eles: “a) a complexidade do assunto; b) o comportamento dos litigantes e de seus procuradores ou da acusação e da defesa no processo; c) a atuação do órgão jurisdicional." 58

Podemos partir, ao menos, de uma ideia de lapso temporal apto e suficiente à solução adequada do conflito, de forma a não obstar a utilidade do provimento buscado e tampouco prejudicar a apuração efetiva do direito substancial das partes, sem descuidar, por óbvio, de todas as demais garantias fundamentais a exemplo do próprio devido processo legal e tudo isso sem perder de vista as especificidades de cada situação de direito material específico $^{59}$.

Registre-se, por oportuno que ainda com maior cuidado deve ser observado esse princípio da duração razoável do processo na seara trabalhista haja vista o caráter alimentar de que se reveste a maioria das demandas ajuizadas na Justiça do Trabalho.

\subsection{Princípios constitucionais do processo}

Impõe-se, para os propósitos deste trabalho mencionar brevemente os princípios constitucionais do processo, aplicáveis que são ao processo do trabalho ${ }^{60}$. Registre-

58 DIDIER JR, Fredie. Curso de Direito Processual Civil vol.1. Salvador: Juspodivm, 2010, p.58

59 Manoel Antonio Teixeira Filho afirma com propriedade que "a razoabilidade na duração do processo, conquanto seja um princípio de ordem geral, haverá de ser estabelecida pelo magistrado em cada caso concreto, conforme as peculiaridades deste". In Curso de Direito Processual do trabalho. Vol. 1São Paulo: LTr, 2009, p.57 60 Sérgio Pinto Martins bem observa a dificuldade até mesmo de se especificar exatamente quais seriam os princípios restritos ao direito processual do trabalho, entendendo tratar-se de matéria muito difícil essa especificação diante da própria divergência entre os vários doutrinadores do processo trabalhista. Este autor parte em sua obra também dos princípios gerais aplicáveis portanto ao processo comum e trabalhista, apontando como o verdadeiro princípio trabalhista o princípio protecionista. In Direito processual do trabalho. São Paulo: Atlas, 2000, pp.62-63. 
se que o fato de encontrarem-se situados no próprio rol do art. $5^{\circ}$. da Constituição da República Brasileira garante aos princípios constitucionais do processo a qualificação como cláusulas pétreas nos termos do art.60, parágrafo $4^{\circ}$ da Lei Maior, de modo que irradiam seus efeitos a todos os ramos processuais, norteando toda a atividade jurisdicional inclusive a da magistratura trabalhista. Nesse compasso toda a interpretação e aplicação das normas processuais inclusive as próprias do processo do trabalho devem partir desse arcabouço principiológico constitucional, que passa a ser analisado na sequência.

Assim os princípios constitucionais do processo devem ser encarados sob o ponto de vista da própria garantia dos direitos fundamentais processuais, constatação a partir da qual (e também considerada a própria dimensão objetiva daqueles direitos), como já visto, impõem ao magistrado sua interpretação conforme os direitos fundamentais, buscando-se sua máxima eficácia. Igualmente poderá o juiz valer-se do princípio da proporcionalidade para afastar qualquer regra que obstaculize a efetivação de todo e qualquer direito fundamental.

\subsubsection{Devido processo legal}

Nos termos da Constituição da República Federativa do Brasil em seu art. $5^{\circ}$, inciso LIV "ninguém será privado de sua liberdade ou de seus bens sem o devido processo legal", consubstanciando-se em verdadeira cláusula geral, representando um direito fundamental com conteúdo complexo, ou seja, é desse princípio que vão se extraindo um número indefinido de outras normas e garantias.

Igualmente Manoel Antonio Ferreira Filho ao tratar do direito processual do trabalho parte dos princípios constitucionais do processo aplicáveis ao processo do trabalho a saber: devido processo legal, inafastabilidade da jurisdição, juiz natural, juízo competente, igualdade de tratamento, contraditório e ampla defesa, publicidade, liceidade dos meios de prova,fundamentação das decisões, duração razoável do processo. O autor aponta ainda em sua obra os princípios infraconstitucionais do próprio processo civil aplicáveis ao processo do trabalho, eis que comuns a ambos, concluindo ao final que os princípios processuais específicos do processo trabalhista seriam apenas dois, quais sejam, o princípio da correção da desigualdade e o da jurisdição normativa. In op.cit. pp.35101. 
Assim pode-se dizer que o conceito do devido processo legal é indeterminado, sendo espécie de cláusula em branco, compreensiva de várias possibilidades e interpretações que variam conforme a própria evolução as sociedade. Representa a garantia de justiça ou direito ao processo justo, proporcionando segundo Eduardo Cambi, "uma configuração não apenas técnica, mas também ético-política ao processo civil, compreendendo não somente a pura ordenação de atos ligados a um procedimento qualquer, mas vinculados ao contrário a um procedimento que assegure a participação contraditória das partes, para que possam sustentar suas razões, produzir as provas e contraprovas necessárias e, assim, ter amplas oportunidades de influir na formação do convencimento do juiz para, com isso, o exercício do poder jurisdicional poder legitimar-se. Nessa perspectiva dinâmica da garantia constitucional do devido processo legal, o procedimento legitima o resultado do exercício do poder e, ao mesmo tempo, é legitimado pelo modo como disciplina esse exercício, na medida em que assegura a aplicação das garantias constitucionais e favorece a efetiva participação dos sujeitos interessados" 61 .

Registre-se ainda que uma das funções do devido processo legal é justamente assegurar o desenvolvimento regular do processo e a observância dos preceitos legais, considerando-se, por isso uma garantia fundamental que se apresenta em duas dimensões, vale dizer, o devido processo legal formal e o devido processo legal substancial ${ }^{\mathbf{6}}$.

Sob o aspecto formal este princípio representa todas as garantias processuais do nível do contraditório, ampla defesa, imparcialidade do juiz, sem presença das quais não estaria legitimado o conteúdo da decisão jurisdicional. Na sua dimensão substancial o devido processo legal exige mais que a observância das formas processuais; exige conteúdo

${ }^{61}$ CAMBI, Eduardo Augusto Salomão. Direito Constitucional à Prova no Processo Civil. São Paulo: Editora Revista dos Tribunais, 2001, pp.111-112.

${ }^{62}$ Sobre a dimensão substantiva do devido processo legal a lição de Canotilho: "A teoria substantiva pretende justificar a idéia material de um processo justo pois uma pessoa tem direito não apenas a um processo legal mas sobretudo a um processo legal, justo e adequado, quando se trate de legitimar o sacrifício da vida, liberdade e propriedade dos particulares. (...)A proteção alargada através de um processo equitativo significará também que o controlo dos tribunais relativamente ao carácter "justo" ou "equitativo" do processo se estenderá, segundo as condições particulares de cada caso, às dimensões materiais e processuais do processo no seu conjunto" In 
adequado, ou seja, um processo que leve a decisões jurídicas proporcionais, razoáveis e justas. $^{63}$

Essa vertente é de máxima importância ao objeto do trabalho em razão das críticas voltadas à teoria da distribuição dinâmica do ônus da prova no sentido de que ao colocar-se de lado as regras do art.333 do Código de Processo Civil e do art.818 da Consolidação das Leis do Trabalho em favor de uma opção de atribuição de ônus vinculada ao caso concreto à míngua de dispositivo legal que autorizasse essa medida estaria sendo violada justamente essa garantia ao devido processo legal. Olvidam-se os detratores da teoria dinâmica que esta não viola a verdadeira garantia que é a do devido processo substancial e não apenas formal, buscando sua fundamentação não na lei positiva, mas também em outros princípios de cunho constitucional que, por meio da ponderação de princípios levam à possibilidade de dinamização do ônus da prova, por exemplo, a partir da necessária promoção da igualdade substancial das partes no processo.

A idéia básica do princípio do devido processo é a de que não poderá haver decisão do juiz sem antes dar às partes a oportunidade de serem ouvidas, significando este princípio uma garantia jurisdicional em si mesma. Pressupõe, pois, a audiência bilateral dos interessados aos quais são assegurados também os poderes, faculdades e direitos processuais. Neste último caso podemos vislumbrar o devido processo legal no seu sentido amplo, ou seja, compreendo todas as demais garantias a exemplo do juiz imparcial, intimações e no que nos interessa muito, à produção de todas as provas que se façam necessárias e sejam aptas a influir no convencimento do juiz. ${ }^{64}$

CANOTILHO, Jose Joaquim Gomes. Direito constitucional e teoria da Constituição. 3. ed. Coimbra: Almedina, 2002, pp.490-491.

${ }^{63}$ DIDIER JR, Fredie. Curso de Direito Processual Civil vol.2. Salvador: Juspodivm, 2009, pp.45-46.

${ }^{64}$ CAMBI, Eduardo. Op.cit. pp. 109-110. 


\subsubsection{Princípio da igualdade e sua projeção no processo}

Eduardo Couture ao tratar do processo como garantia constitucional ensina que as constituições do século XX, com raras exceções, consideravam a necessidade da proclamação programática dos princípios de direito processual conjuntamente com os direitos da pessoa humana e das garantias que lhe eram inerentes, conferindo, entretanto, à doutrina a responsabilidade de delimitar o significado do que fosse, por exemplo, a "plena igualdade", o que não é tarefa nada fácil. ${ }^{65}$

Para esse autor o princípio da igualdade domina o processo civil e na verdade teria uma fórmula simples consubstanciada no "ouvir a outra parte" (ou bilateralidade da audiência) sendo certo que "lo que este principio demanda no es uma igualdad numérica, sino uma razonable igualdad de possibilidades en el ejercicio de la acción y la defensa. Las pequeñas desigualdades requeridas por necesidades técnicas del proceso no quebrantarian el principio." 66

A Constituição brasileira de 1988 traz entre os princípios fundamentais que a informam o princípio da igualdade, inserido em sua parte preambular e no caput do art. 5. ${ }^{\circ}$ e o princípio da dignidade da pessoa, no inciso III, do art. $1 .^{\circ}$. Os dois princípios conjugados formal a base fundante dos demais direitos, tutelando a pessoa humana em toda a sua dimensão, portadora que é de dignidade e igualdade. Verifica-se, portanto que a Constituição em vigor adota uma cláusula geral, como princípio fundamental da ordem jurídica brasileira.

O princípio da igualdade ditado pela Constituição da Republica de 1988, reprova a disparidade entre os cidadãos, tornando-os iguais perante todos os efeitos da lei. O artigo $5^{\circ}$, caput está assim expresso:

\footnotetext{
${ }^{65}$ COUTURE, Eduardo Juan. Fundamentos Del Derecho Procesal Civil. $3^{\text {a }}$.ed. Buenos Aires: Roque Depalma, 1958, pp.151-152

${ }^{66}$ Idem. Ibidem, p. 183
} 
Art. $5^{\circ}$ Todos são iguais perante a lei, sem distinção de qualquer natureza, garantindo-se aos brasileiros e aos estrangeiros residentes no País a inviolabilidade do direito à vida, à liberdade, à igualdade, à segurança e à propriedade, (...)

Cuida-se primeiramente dessa igualdade das pessoas sob o aspecto formal, perante a lei. Na esfera processual, a aplicação do principio da igualdade não se dá de forma diversa. É preciso estabelecer também uma plataforma de igualdade para as partes, sendo o juiz uma peça chave para concreção desse desiderato por meio de determinação legal expressa no Código de Processo Civil (Artigo 125, inciso I, do Código de Processo Civil). ${ }^{67}$ Isto porque a igualdade jurídica absoluta não tem o condão de eliminar as desigualdes econômicas de modo que "do primitivo conceito de igualdade, formal e negativa (a lei não deve estabelecer qualquer diferença entre os indivíduos), clamou-se pela passagem à igualdade substancial e hoje, na conceituação positiva da isonomia (iguais oportunidades para todos, a serem proiciadas pelo Estado), realça-se o conceito realista, que pugna pela igualdade proporcoinal, a qual significa, em síntese, tratamento igual aos substancialmente iguais". ${ }^{6}$

Desta forma a igualdade também é dinâmica e pode ser apreciada sob a perspectiva de uma transformação da igualdade formal em igualdade material, representando esta última um dever do Estado de suprir desigualdade transmutando-a em igualdade real. ${ }^{69}$

Echandia a propósito da projeção do principio da igualdade de oportunidades em matéria de produção de provas, assim se manifestou: "para que haya esa igualdad es indispensable la contradicción; con todo, este principio significa algo más: que las partes dispongan de idénticas oportunidades para presentar o pedir la práctica de pruebas, persigan o no contradecir las aducidas por el contrario. Es un aspecto del principio

\footnotetext{
${ }^{67}$ Art. 125. O juiz dirigirá o processo conforme as disposições deste Código, competindo-lhe: I - assegurar às partes igualdade de tratamento.

${ }^{68}$ CINTRA, Antonio Carlos; GRINOVER, Ada Pellegrini; DINAMARCO, Cândido Rangel. Teoria Geral do Processo. São Paulo: Editora Malheiros, 1995. pp.53-54

${ }^{69}$ GRINOVER, Ada Pelegrini. As garantias constitucionais do processo. Defesa, contraditório, igualdade e par condicio na ótica do processo de estrutura cooperatória. In Novas Tendências do Direito Processual (De acordo com a Constituição de 1988). Rio de Janeiro: Forense Universitária, 1990, p.6
} 
más general de la igualdad de las partes ante la ley procesal, que expusimos en otro lugar, según el cual se exigen las mismas oportunidades para la defensa y se rechazan los procedimientos privilegiados". ${ }^{70}$

Advertência idêntica apresenta Bedaque que após afirmar que a garantia constitucional da isonomia por óbvio deve se espelhar no processo esclarece sobre a existência de regras processuais que não asseguram a efetiva igualdade entre os litigantes, apontado-as justamente como sendo as normas sobre plena disponibilidade da provas, oriundas do superado individualismo liberal e, como postas, podem levar às partes a atuar em juízo em desequilíbrio substancial decorrente de fatores culturais ou econômicos. ${ }^{71}$

O processo, portanto, deverá na fase probatória pautar-se por uma condução que propicie uma efetiva igualdade de direitos e de deveres às partes. Poderá, ainda, ser estabelecida uma relação entre o principio da igualdade e o ônus dinâmico da prova ao atribuí-lo o juiz a quem realmente tenha condições de satisfazê-lo. Assim, na medida em que o magistrado observar que à determinada parte cabia realizar uma prova e não o fez, por exemplo, por questão de hipossuficiência técnica (vulnerabilidade quanto às informações do contrato de trabalho e seria, em razão disso, prejudicada no processo), deverá propor um tratamento diferenciado do ônus da prova para que não se configure ofensa ao princípio da igualdade.

A não interferência do estado-juiz naquele caso beneficiaria apenas a parte contraria ao privilegiar apenas o aspecto formal do princípio da igualdade e não o substancial. Dar concretude, portanto, à igualdade processual em matéria de ônus da prova prestigia o princípio da isonomia e confere equilíbrio aos litigantes com real paridade de armas.

\footnotetext{
${ }^{70}$ DEVIS ECHANDÍA, Hernando. Teoria General De La Prueba Judicial. Buenos Aires: Zavalia, 1981, p.124

${ }^{71}$ BEDAQUE, José Roberto dos Santos. Poderes instrutórios do juiz. São Paulo: Revista dos Tribunais, 2001, pp.96-97.
} 


\subsubsection{Contraditório e o direito à prova}

Também este princípio tem duas dimensões: a formal, garantindo às partes o direito de participar do processo e a vertente substancial, ou seja, o poder de influência na formação da convicção do julgador. Assim, de há muito resta superada a visão do contraditório como singela ciência bilateral das ocorrências do processo, que denotava uma insuficiência de visão totalidade desse princípio, sendo certo que essa antiga concepção atrelava-se a percepção ultrapassada de que o direito deveria ser dito exclusivamente pelo Juiz sem a interferência das partes. Todavia, a realidade da sociedade ao se mostrar mais complexa, impõe permanente sinergia entre o juiz e os demais participantes da relação processual.

Compreender o contraditório como direito de influência além de direito de expressão, fez surgir verdadeira vinculação do juiz ao princípio e um dever de atenção de sua parte, no sentido de instaurar um substancial debate judiciário sobre as questões discutidas no processo. Hoje a "garantia constitucional do contraditório dá conformidade ao direito à prova, assegurando: i) a admissão e produção dos meios de prova, típicos ou atípicos, desde que moralmente legítimos, pertinentes e relevantes; ii) a proibição das limitações probatórias que imponham obstáculos que tornem praticamente impossível ou restrinjam de modo não razoável a prova dos fatos controvertidos; iii) o direito à prova contrária; iv) a tutela contra o perigo de surpresas; v) o direito à valoração da prova produzida."72 (g.n.).

A liberdade concedida ao julgador de escolher a norma a aplicar, independentemente de sua invocação pela parte interessada, consubstanciada no brocardo iura novit curia, não dispensa a prévia oitiva das partes sobre os novos rumos a serem impressos à solução do litígio, em homenagem ao princípio do contraditório. ${ }^{73}$

\footnotetext{
${ }^{72}$ YARSHELL, Flávio Luiz. Antecipação da Prova sem o requisito da urgência e o Direito Autônomo à Prova. São Paulo: Editora: Malheiros, 2009, p.137

${ }^{73}$ OLIVEIRA, Carlos Alberto Álvaro (org). Processo e Constituição. Rio de Janeiro: Forense, 2004. Do formalismo no processo civil. São Paulo: Saraiva, 2010. pp.114-115
} 
O contraditório, assim entendido, representa a própria expressão da democracia participativa do processo, daí que a possibilidade de participação deve ser real e não só formal, de modo a atender ao princípio da igualdade substancial. Essa é também uma das idéias do ônus dinâmico da prova na medida em que em determinadas circunstâncias do caso concreto impor-se-á diferente atribuição do encargo, possibilitando-se prévia e plena ciência às partes que terão desta forma, real possibilidade de participação no processo e influência na formação do convencimento judicial. ${ }^{74}$

\subsubsection{A adequação e a adaptabilidade}

O alcance da garantia da inafastabilidade da jurisdição não se dá contemporaneamente apenas por meio do acesso ao juiz. Exige-se muito mais, especialmente um acesso de forma adequada, ou seja, por intermédio de processo e procedimento adequado aos seus escopos. Logo as próprias regras processuais ao serem concebidas pelo legislador tem que estar focadas no direito material cuja tutela pretendem defender, impondo-se, pois, sua adequação.

Significa este princípio, cuja origem se encontra no próprio principio do devido processo legal, que as regras processuais devem ser adequadas à produção dos resultados esperados no processo, sejam na dimensão objetiva (processo adequado ao direito material que tutela), na dimensão subjetiva (adequado às pessoas que tutela, a exemplo do processo do trabalho que deve observar as especificidades de seus sujeitos, onde um deles geralmente se qualifica como hipossuficiente - essa dimensão do princípio da adequação se

\footnotetext{
${ }^{74}$ Flávio Yarshell bem explica o contraditório sob a perspectiva da prova: "No campo da prova essa visão do contraditório se confirma quando se parte da premissa tradicional de que aquela é dirigida à formação do convencimento do juiz. Nessa ótica, a prova é expressão fundamental do contraditório e se justifica exclusivamente na medida em que possa interferir com a formação do convencimento do órgão julgador". In. Antecipação da Prova sem o requisito da urgência e o Direito Autônomo à Prova. São Paulo: Editora: Malheiros, 2009, p.169. Nesse sentido igualmente Eduardo Cambi: "A decisão judicial se legitima pelo procedimento, legalmente preestabelecido, porque possibilita que as partes participem da formação do convencimento do juiz. $\mathrm{O}$ sistema processual pode ser considerado legítimo quando observa os princípios constitucionais do devido processo legal, da isonomia e do contraditório, já que assim é capaz de oferecer oportunidades para que os destinatários da decisão manifestem seus desejos e insatisfações, evitando a utilização arbitrária do poder estatal." In. Direito Constitucional à Prova no Processo Civil. São Paulo: Editora Revista dos Tribunais, 2001, p.135.
} 
mostra inclusive como um reflexo do princípio da igualdade substancial). Na terceira dimensão verifica-se a necessidade de uma adequação teleológica do procedimento, ou seja, o processo deve ser adequado em relação aos seus fins. No caso do processo do trabalho este deve observar os princípios axiológicos do próprio direito material do trabalho. ${ }^{75}$

Na visão tradicional este princípio dirige-se ao legislador, mas aqui interessa-nos sua visão sob a vertente da adequação jurisdicional do processo, que também é chamado princípio da adaptabilidade do processo, que se traduz no dever do magistrado de, ao se deparar no caso concreto com uma regra inadequada, proceder a sua correção para aplicação e prestação efetiva e justa da tutela jurisdicional.

A partir do reconhecimento da diferença entre os litigantes no processo trabalhista Carlos Alberto Reis de Paula defende igualmente a existência de um princípio da adequação no seguinte sentido:

"Significa esse princípio que o direito processual do trabalho está em conformidade com o direito material do trabalho, na medida em que há uma necessária relação entre estes dois ramos do direito.

O direito processual do trabalho,quando se trata da realização coativa do direito material do trabalho, afirma-se como meio indispensável a esse objetivo. Se o direito material do trabalho tem peculiaridades, obrigatoriamente haverá a adequação a essas singularidades por parte do direito processual do trabalho.",76

Não há portanto como deixar de reconhecer essa necessária ligação entre os dois ramos do direito, sendo que o direito do trabalho se legitima em razão de sua realização efetiva através da instrumentação do processo do trabalho; instrumento este último que deverá

75 A propósito Alexy reconhece ao direito ao procedimento uma perspectiva de direito à proteção efetiva, conforme a lei, mas também conforme a justiça ao assim se manifestar: "Los derechos a procedimientos judiciales y adminstrativos son essencialmente derechos a uma 'protección juridica efectiva'. Condición de una efectiva protección jurídica es que el resultado del procedimiento garantice los derechos materiales del respectivo titular de derechos". E invocando fórmula do Tribunal Constitucional continua: "El derecho procesal sirve para la producción de decisiones conformes a la ley y, desde este punto de vista, correctas pero, además, dentro del marco de esta corrección, justas". ALEXY, Robert. Teoria de los derechos fundamentales. $2^{\text {a }}$.Reimpr. Madrid: Centro de Estudios Constitucionales, 2001, p.472

76 PAULA, Carlos Alberto Reis de. A especificidade do ônus da prova no processo do trabalho. São Paulo: LTr, 2001. pp.120-121. 
ser adequado à tutela exigida pelo direito substancial do trabalho, rico em especificidades dada a realidade humana que lhe é subjacente.

Na abalizada síntese de Fredie Didier "procede-se à adequação do processo ao seu objeto tanto no plano legislativo, abstrato, com a construção de procedimentos compatíveis com as necessidades do direito material, como também no plano do caso concreto, processual, conferindo-se ao órgão jurisdicional o poder de adequar o procedimento às exigências da causa". 77

Igualmente Carlos Alberto Álvaro de Oliveira leciona que

"a organização do procedimento constitui exemplo típico do que se afirmou porque tende a se relativizar em face das circunstâncias concretas da causa. Vigora no particular o princípio fundamental da adequação, também chamado da adaptabilidade. O principal sustentáculo dessa concepção encontra-se, sem dúvida, na necessidade de se emprestar a maior efetividade possível ao direito processual no desempenho de sua tarefa básica de realização do direito material e de outorga de justiça." 78

Desta forma, adequar as regras de atribuição do ônus da prova a partir do próprio direito material tutelado pelo processo do trabalho significa a implementação por meio desta via do próprio princípio do devido processo legal.

\subsubsection{Lealdade e boa-fé}

Através do princípio da boa-fé impõe-se aos sujeitos processuais que se tratem com respeito uns com os outros, praticando a lealdade e a ética. Pauta-se especialmente nos dispositivos legais insertos nos artigos 14, 16 a 18 e 125, III, do Código de Processo Civil.

O princípio da cooperação que se extrai do art. $3^{\circ}$, I, da Constituição da República Brasileira bem assim do disposto nos artigos 339, 340, 342, 345 e 355, do Código

\footnotetext{
${ }^{77}$ DIDIER JR, Fredie. Curso de Direito Processual Civil vol.1. Salvador: Juspodivm, 2009, p.73

${ }^{78}$ OLIVEIRA, Carlos Alberto Álvaro. Do formalismo no processo civil. São Paulo: Saraiva, 2010, pp.160-161
} 
de Processo Civil conjuga-se com o próprio princípio da boa-fé na medida em que todos os atores processuais tem que cooperar no sentido de melhora da solução do conflito, em prol da descoberta da verdade dos fatos, gerando inclusive deveres ao juiz a exemplo do dever de esclarecimento às partes sobre o encargo da prova de cada qual, mormente ao aplicar a teoria dinâmica do encargo da prova que não sendo apriorística, não se pauta portanto pela divisão a partir dos fatos e posição processual dos sujeitos.

Registre-se, por oportuno, que embora a busca por verdadeiros deveres em matéria probatória decorra justamente da valorização ética do processo, o conteúdo desses deveres é difícil de explicitar. Para Flávio Yarshel o dever de lealdade em matéria de prova se traduz num dever de veracidade, caracterizado por um elemento subjetivo, ou seja, viola o dever quem alega fatos que razoavelmente deveria saber de antemão que são inverídicos. ${ }^{79}$

Quanto ao próprio dever de colaboração o mesmo autor esclarece seu surgimento no contexto da garantia do contraditório a partir do reconhecimento, neste último, da expressão se sua natureza como "diálogo" para formação do juízo de convencimento, "fruto então, da colaboração e da cooperação das partes com o órgão judicial e deste para com aquelas". Continua o autor "mais uma vez não se pode negar que a busca de um autêntico dever de colaboração ou de cooperação das partes - tanto mais de forma específica em matéria de prova - está intimamente relacionado à ênfase para o aspecto ético do processo, como instrumento a serviço dos escopos de atuação da vontade concreta do direito objetivo e de pacificação social para eliminação das controvérsias" 80

Desta forma em matéria especificamente de ônus da prova e sua distribuição há que ser dada relevância à própria contribuição trazida pelas partes, ou seja, a própria conduta destas é dado a ser levado em conta pelo magistrado na avaliação das circunstâncias do caso concreto.

\footnotetext{
${ }^{79}$ YARSHELL, Flávio Luiz. Op.cit., pp.154-155.
} 


\section{Direito constitucional à prova e ao ônus da prova}

O princípio do acesso à justiça eminentemente de grandeza constitucional reflete sobre o processo como um todo e não seria diferente em relação ao instituto da prova e em especial sobre a questão do ônus da prova.

Ressalte-se prima facie o escasso tratamento na doutrina relativamente à questão do direito constitucional ao ônus da prova. Canotilho aponta especificamente para o déficit de tratamento do direito à prova pelos próprios juspublicistas, o que significa também a inexistência de problematização jurídico-constitucional relativa a categorias jurídicas tão importantes como a do ónus da prova, nas palavras do constitucionalista português, para quem há um verdadeiro direito constitucional do ônus da prova. ${ }^{81}$

Afirma com propriedade o autor português que

"se o direito constitucional à prova não tem sido objecto de desenvolvimento aprofundado, não é de admirar que o problema do ónus da prova seja também remetido para a ciência jusprocessualisa (civil, penal e administrativa). A remissão sistemática do regime jurídico do ônus da prova para o direito processual legalmente estabelecido pode, porém, suscitar sérias interrogações em domínios tão sensível num Estado de Direito democrático-constitucional como é o do regime de direitos, liberdades e garantias. (...) O princípio básico sobre a repartição do ônus da prova resolve-se contra a parte a quem o facto aproveita (assim, precisamente, o art.516 ${ }^{\circ}$. do Código de Processo Civil Português). Transferindo de plano este princípio para os direitos, liberdades e garantias, o princípio de repartição do ônus da prova poderia formular-se assim: quem invocar um direito fundamental (rectius: um direito, liberdade e garantia) deve fazer prova de que lhe assiste esse direito). Mas as coisas não são assim tão simples (...) ${ }^{82} 171$

Prossegue Canotilho:

" Os direitos fundamentais transportam sempre uma dimensão subjectiva (<são direitos das pessoas>)e uma dimensão objectiva (transportam dimensões jurídco-objectivas que devem pautar a conformação do direito ordinário). Compreende-se que, quando a medida justa da distribuição do ônus de prova é fundamental para a garantia de um direito, se

\footnotetext{
${ }^{80}$ Idem.Ibidem, p.164

${ }^{81}$ CANOTILHO, Jose Joaquim Gomes. O Ónus da prova na jurisdição das liberades: para um teoria do direito constitucional à prova. Estudos sobre Direitos Fundamentais. 1 ${ }^{\text {a }}$. Edição brasileira. São Paulo: RT, 2009.p.170

${ }^{82}$ Ibidem. p. 171
} 
devam evitar teorias abstractas e apriorísticas (como a já referida de Rosenberg) e se imponham soluções probatórias não aniquiladoras da própria concretização de direitos, liberdades e garantias." ${ }^{83}$ (g.n.)

Canotilho parte das regras do onus probandi de Rosenberg ${ }^{84}$ e reconheceas como insuficientes para satisfazer plenamente as situações do direito material.

Igualmente crítico em relação às normas de distribuição do ônus da prova a partir da categorização dos fatos (constitutivos, extintivos, impeditivos, modificativos), classifica-as como um mecanismo artificial em que não há espaço para a consideração do que efetivamente ocorre no plano do direito material, ou seja, na própria vida do jurisdicionado. ${ }^{85}$

Desta forma, a atribuição do encargo da prova tem que observar as especificidades do caso concreto amparadas pelo direito material próprio, o que releva a importância das presunções legais relativas e presunções judiciais referentes a certas situações de direito substancial que provoquem a distribuição do ônus da prova de forma diversa da distribuição estática da lei, ou ainda, a própria aplicação do art. 333 do Código de Processo Civil e do art.818 da CLT, mas de forma atenuada, cabendo ao magistrado sempre justificar seu procedimento nestes casos. ${ }^{86}$

Para a percepção da importância da questão basta compreender que no julgamento dos casos que lhe são propostos o magistrado analisará a incidência da norma ao fato afirmado pela parte e a demonstração desse mesmo fato está sujeita à produção de provas, das quais igualmente dependerá o próprio direito de acesso à justiça posto configurarem-se no meio de convencimento do juiz quanto ao direito ameaçado ou lesionado. Consequentemente

\footnotetext{
${ }^{83}$ Ibidem. p. 175

${ }^{84}$ Esquematiza Canotilho a regra de Leo Rosenberg da seguinte maneira: (1) qualquer parte em litígio tem de afirmar e demonstrar os pressupostos da norma que a favorece; logo, (2) o pretendente deve demonstrar os pressupostos fundamentais do seu direito; (3) o contraditor os pressupostos das normas impeditivas" ob.cit. p.175

${ }^{85}$ MARINONI, Luiz Guilherme; ARENHART, Sérgio Cruz. Prova. São Paulo: Ed. Revisa dos Tribunais, 2010, p. 167

${ }^{86}$ Ibidem, pp.167-168
} 
as regras de atribuição do próprio ônus da prova poderão refletir no próprio direito de acesso à justiça. $^{87}$

Compreendendo o direito de ação a oportunidade das partes influírem no convencimento do juiz através de participação efetiva no processo, não há como deixar de reconhecer o próprio direito à prova como um dos instrumentos inerentes para essa participação. Não menos certo, portanto que a distribuição do ônus da prova seja também uma questão de ordem constitucional. ${ }^{88}$

Em síntese, como ensina Danilo Knijnik “a violação do direito à prova pode implicar, de um lado, a inutilidade da ação judiciária, caracterizando, assim, violação oculta à garantia de acesso útil à justiça". Continua ainda o autor: "essa perspectiva conduz-nos a certas situações nas quais a aplicação das regras sobre o ônus da prova pode acarretar manifesta injustiça, a ponto de inviabilizar o acesso útil ao Poder Judiciário, violando-se, ainda que de forma oculta, o art.5 ${ }^{\circ}$, XXXV, da CF.", 89

O próprio reconhecimento do direito de ação no âmbito constitucional levou às garantias do devido processo legal e seus corolários do contraditório e da ampla defesa, representando o mesmo fenômeno, qual seja, conferir aos litigantes através do sistema processual, a maior possibilidade de atuar para a formação do convencimento do juiz, o que implica, por consequiência, na própria possibilidade de produção de provas destinadas a esse mister. Assim, o direito a prova não pode mais se dissociar do contraditório e da ampla defesa e tampouco pode ser tratado apenas sob o prisma do art.333 do CPC, impondo-se seu o reconhecimento também como garantia constitucional e desta forma dotado de efetividade para assegurar o direito material discutido. ${ }^{90}$

87 GODINHO, Robson Renault. A distribuição do ônus da prova na perspectiva dos direitos fundamentais. Revista da EMERJ. Rio de Janeiro, v. 10, n. 38, p. 263-84, abr./jun. 2007. pp. 265-267

${ }^{88}$ Idem.Ibidem. pp.272-273

${ }^{89}$ KNIJNIK, Danilo. As (perigosíssimas) doutrinas do 'ônus dinâmico da prova' e da 'situação do senso comum' como instrumentos para assegurar o acesso à justiça e superar a probatio diabólica. Processo e Constituição: Estudos em Homenagem ao Professor José Carlos Barbosa Moreira. São Paulo: RT, 2006, p.943

${ }^{90}$ BEDAQUE, José Roberto dos Santos. Poderes instrutórios do juiz. São Paulo: Revista dos Tribunais, 2001, pp. 20-21 
Para atingir o propósito de acesso a uma ordem jurídica justa, portanto, as partes devem estar garantidas quanto às possibilidades de produção de suas provas, mas também haverá a confecção desses elementos probatórios por um outro sujeito interessado, qual seja, o juiz que poderá determinar as provas necessárias à sua convicção. ${ }^{91}$

Do exposto, o instituto do ônus da prova conquanto elemento essencial do processo deve ter as mesmas garantias deste no sistema democrático, de modo que a distribuição da carga probatória realizada pelo juiz não possa sofrer críticas sob simples fundamento de ausência de previsão legal porquanto amparada na própria Constituição.

A idealização constitucional do direito à prova tem adeptos a exemplo de Comoglio que ao tratar de garantias mínimas para um processo civil justo no ordenamento hispano-latinoamericano apresenta no apêndice da sua obra uma base constitucional mínima onde é feita referência expressa ao direito à prova e ao ônus da prova, apresentando até mesmo um projeto de normas constitucionais uniformes em conjunto com Augusto Morello que prevê no artigo 12: ${ }^{92}$

"Nell'esercizio del diritto fondamentale alla prova (supra,sub art.7) incombe all' attore l' onere di allegare e di provare $i$ fatti, sui quali si fonda la sua domanda; incombe, invece, aL convenuto l'onere di allegare e di provari i fatti, su quali si fondano le sua eccezini o difese.

Chi non assolve gli oneri da cui è gravato, sopporta il rischio della mancata prova, soccombendo nel giudizio. Ciascuna parte ha il diritto e l'onere di domandare al giudice l'adozione di provvedimenti coattivi di esibizione o di discovery) delle prove rilevanti, di cui non abbia la materiale disponibilità, nei confronti di un'altra parte o di un terzo che le

\footnotetext{
${ }^{91}$ Idem.Ibidem.p. 22.

92 COMOGLIO, Luigi Paolo. Etica e tecnica del giusto processo. Torino: G. Giappichelli, 2004, p.411. Ainda, na tradução livre da autora: "no exercício do direito fundamental à prova incumbe ao demandante a carga de alegar e provar os fatos sobre os quais se funda sua demanda; incumbe, em troca, ao demandado o ônus de alegar e provar os fatos sobre os quais se fundam suas exceções e defesas. Quem não satisfaz o ônus da prova que sobre ele recai suporta o risco da falta de prova e desconsideração de suas pretensões. Cada parte tem o direito e o ônus de pedir ao juiz a adoção de medidas coativas de exibição (ou descoberta) de provas relevantes, que não estejam sob sua disposição material, em face das demais partes ou terceiros. A lei determina sanções aplicáveis às partes e aos terceiros em caso de negativa injustificada à exibição".
} 
detengano. La legge determina la sanzioni irrogabili nei confronti di chi rifiuti, senza giustificato motivo, l'esibizione ordinata dal giudice”.

Registre-se, por fim, que o modelo constitucional do processo e via de consequiência da prova e suas regras distributivas de ônus tem por fim a prestação de justiça ao caso concreto e nessa perspectiva deve-se dar a devida ênfase aos direitos fundamentais processuais que garantem tanto quanto possível os mecanismos adequados à solução dos litígios quanto o resultado justo da decisão. 


\section{CAPÍTULO II - ÔNUS DA PROVA: PANORAMA NA TEORIA GERAL PROCESSO E SUAS ESPECIFICIDADES NO PROCESSO TRABALHISTA}

\section{Introdução}

Registre-se inicialmente que a abordagem do tema do ônus da prova num mesmo capítulo sob os prismas civilista e trabalhista não se apresenta como antagônica, porquanto com a evolução do processo civil, principalmente em termos de técnicas e procedimentos, aquele mais se aproximou da própria índole do processo do trabalho pelo que acredito, ao menos desde as novas ondas reformatórias do processo civil, ser desnecessária a preocupação exacerbada na defesa da autonomia do processo do trabalho, aplicando-se a este, sem sombra de dúvida, os primados fundamentais do processo civil vistos no capítulo precedente a exemplo das questões do acesso a justiça, contraditório, instrumentalidade. O ajuste de procedimentos ou técnicas processuais é que vai variar segundo as especificidades das relações jurídicas materiais tuteladas em cada segmento. ${ }^{93}$

A discriminação do ônus da prova pelo art.333 do CPC conforme a concepção clássica seria objetiva e fixa, vinculando-se à atividade das partes em prol da consecução de seus direitos. Incumbência "individual" da parte que é "responsável" por provar suas alegações. ${ }^{94}$ Entretanto essa regra absoluta de divisão do ônus da prova não mais

${ }^{93}$ SOUTO MAIOR, Jorge Luiz. Direito Processual do Trabalho. Efetividade, Acesso à Justiça e Procedimento oral. São Paulo: LTr, 1999.p.21

${ }^{94}$ Como bem adverte Marcelo Abelha Rodrigues "a regra de distribuição do ônus da prova na forma mencionada está vinculada à ideologia de um Estado Liberal, porque é o aspecto subjetivo da prova que delimita a atuação e contornos do aspecto objetivo da prova, ou seja, a contrario sensu, o juiz não pode deixar de julgar alegando falta ou insuficiência de prova, conquanto caiba às partes, precipuamente, o encargo de municiá-lo sobre as provas que servirão à formação do seu convencimento. Assim, se as partes não oferecem subsídios - e este é um problema que lhes pertence, segundo o estado Liberal -, deve assim mesmo o juiz julgar, formando seu convencimento sobre o material probatório que lhe foi fornecido. A busca e a investigação da prova pelo próprio juiz são algo excepcional e subsidiário no direito processual civil tradicional. In RODRIGUES, Marcelo Abelha. A distribuição do ônus da prova no Anteprojeto do Código Brasileiro de Processos Coletivos. In: GRINOVER, Ada Pellegrini Grinover; MENDES, Aluisio Gonçalves de Castro; WATANABE, Kazuo (coords.). Direito 
se sustenta nessa acepção no próprio processo civil diante das transformações da sociedade e do reconhecimento constitucional da isonomia real das pessoas. Daí a necessária atuação concreta do juiz na busca também pela prova que lhe possibilitará a formação da convicção, trazendo como resultado último e esperado a pacificação do conflito social.

Cândido Rangel Dinamarco adverte inclusive que as regras de distribuição do ônus da prova não devem ser interpretadas como limitadores dos poderes instrutórios do juiz que deve ter atuação ativa no âmbito da instrução processual, com o fim de corrigir eventuais desequilíbrios na produção probatória e chegar a uma decisão mais justa e equânime.

A visão publicista da prova aparece com todo seu resplendor nas disposições do Código de Defesa do Consumidor que partindo do reconhecimento de que nem todas as pessoas tem as mesmas condições técnicas ou econômicas, traz importante regra de inversão do ônus da prova associada aos casos concretos. O Código de Defesa do Consumidor confere poderes ao juiz para, utilizando-se de dados fáticos e concretos que refogem ao controle do legislador (verossimilhança de alegações, hipossuficiência do consumidor), atribua ele, julgador, o encargo da prova. ${ }^{95}$

Nessa onda renovatória de "flexibilização" da regra do art.333 do CPC segue o Anteprojeto Brasileiro de Processos Coletivos, trazendo regras sensíveis às circunstâncias da causa e condições da parte humana envolvida ${ }^{96}$, bem assim o Anteprojeto do Código de Processo Civil ${ }^{97}$.

Processual Coletivo e o Anteprojeto de Código Brasileiro de Processos Coletivos. São Paulo: Revista dos Tribunais, 2007, p.244.

${ }^{95}$ DALL'AGNOL JUNIOR, Antonio Janyr. Distribuição Dinâmica dos Ônus Probatórios. Revista Jurídica, 137. Porto Alegre, no. 280, 2001

${ }^{96}$ Art.10 do Anteprojeto: Art.10. Provas.(...) Parágrafo primeiro: Sem prejuízo do disposto no art.333 do CPC, o ônus da prova incumbe à parte que detiver conhecimentos técnicos ou informações específicas sobre os fatos, ou maior facilidade em sua demonstração. Parágrafo segundo. O ônus da prova poderá ser invertido quando, a critério do juiz, for verossímil a alegação, segunda as regras ordinárias de experiência, ou quando a parte por hipossuficiente; Parágrafo terceiro. Durante a fase instrutória, surgindo modificação de fato ou de direito relevante para o julgamento da causa (parágrafo único do art.4 ${ }^{\circ}$. deste Código), o juiz poderá rever, em decisão motivada, a distribuição do ônus da prova, concedendo à parte a quem for atribuída a incumbência prazo razoável 
Neste capítulo, portanto, serão inicialmente abordadas as noções de ônus e dever, percorrendo sinteticamente suas dimensões, com diferenciação das perspectivas objetivas e subjetivas, com ênfase na questão dos poderes instrutórios do juiz. De fato a jurisdição no Estado Democrático de Direito tem sido vista sob novas perspectivas que levaram à mudança de sua concepção de modo a fundamentar especialmente os poderes instrutórios do juiz, extremamente vinculados à distribuição do ônus da prova

Na parte final será apreciada especificamente a distribuição estática do ônus da prova e sua flexibilização atual, seguindo-se a apreensão da controvérsia quanto ao momento processual da modificação do ônus da prova e a positivação contemporânea das regras do ônus da prova no Código de Processo Civil, Código de Defesa do Consumidor e especial e particularmente na Consolidação das Leis do Trabalho.

\section{2. Ônus da prova - generalidades}

A questão do ônus da prova e sua atribuição tem extrema relevância no processo a partir do momento em que este último passou a ser o instrumento do Estado para a solução dos conflitos após ultrapassar a fase da autodefesa. A jurisdição passa a ter o dever constitucional de dar uma resposta a sociedade dirimindo conflitos e a partir dessa perspectiva não é lícito ao juiz calar-se mesmo no caso da inexistência de comprovação dos fatos pelas partes (non liquet) ou mesmo de dúvida em relação aos acontecimentos. O juiz precisa

para sua produção, observado o contraditório em relação à parte contrária (art.23, § 5. ,IV).Parágrafo quarto: O juiz poderá determinar de ofício a produção de provas, observado o contraditório.

97 Art. 261 do Anteprojeto do CPC: O ônus da prova, ressalvados os poderes do juiz, incumbe:I - ao autor, quanto ao fato constitutivo do seu direito;II - ao réu, quanto à existência de fato impeditivo, modificativo ou extintivo do direito do autor.Art. 262. Considerando as circunstâncias da causa e as peculiaridades do fato a ser provado, o juiz poderá, em decisão fundamentada, observado o contraditório, distribuir de modo diverso o ônus da prova, impondo-o à parte que estiver em melhores condições de produzi-la. $\$ 1^{\circ}$ Sempre que o juiz distribuir o ônus da prova de modo diverso do disposto no art. 261, deverá dar à parte oportunidade para o desempenho adequado do ônus que lhe foi atribuído. $\S 2^{\circ} \mathrm{A}$ inversão do ônus da prova, determinada expressamente por decisão judicial, não implica alteração das regras referentes aos encargos da respectiva produção. 
reconstruir os fatos que amparam o pedido das partes e subsumi-los à norma material aplicável. Daí a importância fundamental da categoria em estudo para o processo enquanto, repita-se, meio estatal de solução das lides havendo que se questionar, no decorrer do capítulo, se o ônus da prova como regra de julgamento se mostra mais relevante do que no seu sentido subjetivo.

Essa grandeza revela-se também pela quantidade de estudiosos que trataram do tema cada qual em sua época. ${ }^{98}$ Michele inclusive aborda o assunto tratando da história de um dogma, reconhecendo o ônus da prova como um dos aspectos essenciais da função jurisdicional, mormente para a consecução dos fins do processo. ${ }^{99}$

Cândido Dinamarco conceitua o ônus da prova como o "encargo, atribuído pela lei a cada uma das partes, de demonstrar a ocorrência dos fatos de seu próprio interesse para as decisões a serem proferidas no processo", ${ }^{100}$ de modo que embora não trazendo sanções às partes (vez que não se trata de um dever na concepção do autor), elas participam ativamente do procedimento sob a perspectiva da incidência dos efeitos jurídicos negativos que poderão decorrer de sua inércia. Assim, mesmo entendendo o ônus apenas como encargo, essa técnica incentiva a atuação das partes, apesar de, repita-se, não terem elas, a princípio, dever de agir na concepção tradicional do ônus da prova. ${ }^{101}$

98 CARPES, Artur Thompsen. Prova e Participação no Processo Civil: Dinamização dos ônus probatórios na perspectiva dos direitos fundamentais. Tese (Mestrado), Faculdade de Direito, Universidade Federal do Rio Grande do Sul, 2008, p.42

99 MICHELI, Gian Antonio. La carga de la prueba. Buenos Aires: Ediciones juridicas Europa-America, 1961, p. 12

${ }^{100}$ DINAMARCO, Cândido Rangel. Instituições de direito processual civil. Vol.III. São Paulo: Malheiros, 2003, p.72. O autor pátrio afirma ainda que "o manuseio da técnica consistente em impor ônus às partes, muito intenso no processo civil dispositivo, produz o efeito de motivá-las a participar ativamente do contraditório processual porque sabem quais consequências a sua desídia ou as suas omissões poderiam importar. $\mathrm{O}$ onus probandi inserese nesse contexto de motivações, levando cada um dos litigantes a participar da instrução probatória segundo seu próprio interesse e com vista à defesa de suas pretensões através do processo"

${ }_{101}$ Sobre esse "incentivo" à atividade das partes, gerado a partir da interpretação da regra do ônus probatório precisa é a manifestação de José Carlos Barbosa Moreira no sentido de que para a compreensão desse mecanismo "é preciso atentar na ideia que o inspira. Parte-se da premissa, explícita ou implícita, de que o maior interessado em que o juiz se convença da veracidade de um fato é o litigante a quem aproveita o reconhecimento dele como verdadeiro, por decorrer daí a afirmação de um efeito jurídico favorável a esse litigante, ou a negação de um efeito jurídico a ele desfavorável. Semelhante interesse naturalmente estimula a parte a atuar no sentido de persuadir o órgão judicial de que o fato deveras ocorreu - numa palavra: de prová-lo. Todo ordenamento processual, sejam quais forem as diretrizes filosóficas ou políticas que o inspirem, conta em larga extensão com a 
De fato, quando falarmos oportunamente em ônus da prova dinâmico esse encargo passa a assumir certo grau do que podemos chamar de "coercibilidade" a partir das próprias ideias supra referidas, ou seja, se a previsão legal como hoje instituída acerca da atribuição do ônus da prova na forma genérica do art.333 do Código de Processo Civil já tem o condão de induzir à participação, se não sob o forte receio de ter seu pedido rejeitado, na hipótese então de se verem as partes diante da "dinamização dos seus ônus", mais se dedicariam a trazer aos autos as contribuições possíveis à demonstração de sua tese em verdadeira harmonia com a noção de processo colaborativo.

Considerado o ônus como encargo não há propriamente um dever de provar, mas sim um "imperativo ao interesse" de cada um na expressão de Eduardo Couture, para quem a carga da prova supondo tal imperativo denota uma situação de risco consistente no fato de ter de provar a verdade dos fatos sob pena de perder o pleito. Para esse processualista, portanto, o ônus da prova num primeiro momento significa uma conduta imposta a ambos os litigantes para que provem a verdade dos fatos que trazem ao processo e num segundo momento cria-se pela lei ainda que implicitamente uma situação embaraçosa para o caso de não se comprovar a tal verdade; situação perigosa da qual os litigantes só poderão se livrar caso provem a verdade dos fatos. ${ }^{102}$

$\mathrm{Na}$ verdade o ônus da prova traz ínsitos dois significados. O primeiro relaciona-se com a necessidade das partes demonstrarem suas afirmações por meio da prova dos fatos que as embasam. O segundo significado corresponde ao dever do juiz de decidir desfavoravelmente a quem deveria ter realizado as provas e não o fez. Implicaria portanto o

eficácia desse estímulo. O desejo de obter a vitória cria para o litigante a necessidade, antes de mais nada, de pensar os meios de que se poderá valer no trabalho de persuasão e de esforçar-se, depois, para que tais meios sejam efetivamente utilizados na instrução da causa". BARBOSA MOREIRA, José Carlos. Julgamento e ônus da prova. In Temas de Direito Processual: segunda série. Saraiva, 1988. p. 74

${ }^{102}$ COUTURE, Eduardo Juan. Fundamentos do Direito Processual Civil. (trad. Rubens Gomes de Sousa). São Paulo: Saraiva, 194, p.241. Nesse sentido, compreendendo o ônus como interesse próprio e também vislumbrando uma ótica de "liberdade" SENTIS MELENDO, Santiago. Natureza da Prova. A prova é liberdade. São Paulo. Revista Unifieo. Ano V.no.8, Jan/Jun/2008., p.175 
onus probandi num princípio de autorresponsabilidade das partes em face de seu duplo efeito jurídico, a saber, uma carga processual para a parte e um dever para o juiz. ${ }^{103}$.

Outro significado muito importante nos é indicado por Flávio Yarshell ao perceber no ônus da prova não só o interesse das partes, mas também um autêntico interesse público, ${ }^{104}$ pois sendo o juiz o destinatário da prova na busca da verdade possível para a formação da sua convicção, interessa ao Estado, pois que as partes realizem as provas de modo que não se pode pensar que o não atendimento ao ônus da prova provoque consequências desfavoráveis só para a parte a quem se atribui o encargo. Na visão do autor interessa ao Estado essa produção de provas com a consequente edição de decisões justas de modo a integrar a ideia de processo efetivo. Para o autor "quando o Estado, para afastar o non liquet, é forçado a proferir julgamento sem ter efetivo conhecimento dos fatos há ao menos em termos lógicos, uma perda para o interesse público que, repita-se se satisfaz - embora não exclusivamente - com decisões justas, entendidas como aquelas afeiçoadas, em concreto e tanto quanto possível, à vontade do direito abstratamente concebido" 105 .

Há quem entenda, ainda, a questão sob o prisma de um poder-dever na medida que não é possível ao juiz eximir-se do julgamento em razão do princípio constitucional da inafastabilidade da jurisdição, alegando ausência ou insuficiência de provas ou ainda dúvidas e incertezas quanto aos fatos. A ideia do poder-dever focaliza mais o aspecto objetivo do ônus da prova. ${ }^{106}$

O ônus da prova não se confunde com uma obrigação em sentido técnico na medida em que esta última juntamente com o dever, levam à sujeição do litigante ou ao

${ }^{103}$ LÓPEZ-MIRÓ, Horacio G; CALANDRI, Laura Cristina [et al.]. Probar o sucumbir: los tres grados del convencimiento judicial y la regla procesal del onus probandi. Buenos Aires: Abeledo-Perrot, 1998, p.35

${ }^{104}$ Sérgio Pinto Martins ao tratar dos princípios das provas já reconhecia como um deles o da "obrigatoriedade da prova", na medida em que "a prova é de interesse não só das partes, mas também do Estado, que pretende o esclarecimento da verdade". Continua o autor "Tem o juiz ampla liberdade na direção do processo (art.765 da CLT), podendo determinar que seja feita a prova que julgar necessário". In. Direito processual do trabalho. São Paulo: Atlas, 2000, p.283

${ }^{105}$ YARSHELL, Flávio Luiz. Antecipação da Prova sem o requisito da urgência e o Direito Autônomo à Prova. São Paulo: Malheiros, 2009, p.51

106 SANTOS, Ernane Fidélis dos. Manual de direito processual civil. Vol. 1. São Paulo: Saraiva, 1997, p.8. 
estabelecimento de um vínculo, sem liberdade de conduta, submetendo-se a consequências desfavoráveis caso não cumpra a conduta determinada na norma jurídica. O descumprimento do encargo da prova não leva necessariamente a uma perda processual, na medida em que, repita-se, trata-se de um interesse próprio que não obriga o sujeito à conduta, embora pendente a possibilidade de prejuízo. Se pensarmos também no próprio princípio da aquisição processual da prova e nos poderes instrutórios do juiz ainda mais fácil será a compreensão da relatividade das consequências advindas da inércia das partes. ${ }^{107}$

Segundo Eduardo Cambi o ônus pode então ser definido como "a liberdade de realização de certos atos ou condutas previstas em uma norma jurídica, para a satisfação de um interesse próprio, não havendo sujeição ou um outro sujeito que tenha o direito de exigir a sua observância, visto que o seu não-cumprimento pode acarretar apenas consequências desfavoráveis para a pessoa beneficiada". Já o ônus da prova possuiria uma particularidade, qual seja, o fato de seu descumprimento não acarretar impositivamente uma conseqüência desfavorável vez que a realização da prova não seria determinante para o sucesso na disputa judicial, embora aumente o risco de uma decisão contrária aos interesses do inerte. ${ }^{108}$

Após realizar um estudo profundo das várias conotações do ônus da prova o processualista português Rui Rangel fornece uma exata noção do que seja o ônus da prova, cumprindo aqui retratá-la por sua precisão:

“(...) o ônus é um poder ou faculdade de desenvolver e executar livremente certos actos ou adoptar ou não certa conduta prevista para benefício e interesse próprio sem qualquer sujeição ou coacção e sem que seja possível outro agente exigir a sua observância, comportando, a omissão do comportamento ou o incumprimento, um risco gerador de consequências desfavoráveis e desvantagens. Existe, por isso, um verdadeiro ônus processual no que concerne ao ônus da prova para o sujeito com esse encargo que fica obrigado a uma responsabilidade objectiva processual. O efeito imediato da inércia da parte é a inevitabilidade do decaimento da acção, o

107 CAMBI, Eduardo Augusto Salomão. A prova civil: admissibilidade e relevância. São Paulo:Revista dos Tribunais, 2006, p.315

108 Ibidem. pp.315-316. 
que faz nascer acoplado a este ônus processual um principio de auto responsabilização." 109 .

Na verdade a doutrina tem-se mostrado pacífica quanto à compreensão do encargo da prova como um ônus, não representando um dever jurídico porque se a parte dele não se desincumbir não sofrerá nenhuma sanção jurídica e tampouco uma obrigação ou dever o seu cumprimento na medida em que este se daria em relação a alguém enquanto que o ônus é do interesse da própria parte, ou seja, voltado para si mesma, vez que se não produzir a prova possivelmente pode não ter acolhida a sua pretensão.

Em síntese, não há verdadeiro dever de provar uma vez que uma parte não pode exigir isso da outra. Há só ônus com assunção de risco pelo ator processual de não provar os fatos arguidos e dos quais dependa o reconhecimento do direito postulado por meio da tutela jurisdicional requerida.

Por fim há ainda que se fazer uma breve menção à natureza das regras jurídicas que cuidam da atribuição do ônus da prova, eis que ponto importante para o tema em discussão neste projeto na medida em que como se verá no último capítulo a atribuição do ônus da prova dinâmico será influenciada pelo direito material revolvido no processo.

Há quem atribua a essas regras do ônus da prova natureza jurídica material na medida em que determinam o conteúdo da decisão jurisdicional. Por outro lado, e considerando-se essa mesma sentença, embora apoiada a decisão no direito material, com ele não se confunde. Como bem sintetizou Artur Carpes, com apoio na doutrina de Micheli, Echandia e Rui Rangel “inegável, pois que o direito material, quando declarado na sentença, vai influenciado pelo processo no qual foi inserido, inicialmente, apenas em linha de afirmação. Afinal, 'reconhecer que a estrutura do procedimento influi sobre a regra de juízo, que dá ao juiz o modo de pronunciar em todos os casos, significa admitir que os princípios

\footnotetext{
${ }^{109}$ RANGEL, Rui Manuel de Freitas. O Ônus da prova no processo civil. Coimbra: Livraria Almedina, 2000, p. 94
} 
dominantes em um determinado processo sejam fatores determinantes da regra mesma, a qual por tanto se manifesta como perfeitamente aderente ao processo concreto" de modo que não há como desconhecer também a índole processual dessas regras. ${ }^{110}$

Carnelutti é quem bem sistematiza o problema ao afirmar que:

"la regla es, por tanto, en su fórmula más general, que la falta de certeza de un hecho perjudica a aquella de las partes que tiene interés en su afirmación y, por tanto, la falta de certeza del hecho constitutivo perjudica aquien hace valer el derecho, mientras que la falta de certeza del hecho extintivo o invalidativo perjudica a aquel contra quien se lo hace valer. De la aplicación de esta regla deriva un nuevo aspecto de la carga de la prueba, en el sentido de que cada una de las partes tiene que proponer la prueba de los hechos en cuya afirmación está interesada, no sólo en cuanto dicha prueba no puede el juez buscarla por sí, sino en cuanto el hecho será reconocido inexistente también si falta la prueba.

El instituto de la carga de la prueba, tiene, pues, dos caras, una de derecho procesal y otra de derecho material, por lo cual es justo que de él se ocupen tanto el Código de procedimiento como el Código civil;","l11 (g.n.)

\section{Dupla dimensão do ônus da prova - ônus subjetivo e ônus objetivo}

A dupla perspectiva ou função do ônus da prova não tem escapado à visão dos doutrinadores seja no processo civil seja no trabalhista ${ }^{112}$, vez que ao ônus da prova cabe inicialmente a função de regra de determinação da conduta das partes indicando a cada qual os fatos que devem provar. As partes, tendo o encargo da prova e não o satisfazendo assumem seus próprios riscos quanto à dúvida ou incerteza subsistentes e daí falar-se inicialmente nesse viés negativo do ônus da prova.

${ }^{110}$ CARPES, Artur Thompsen. Prova e Participação no Processo Civil: Dinamização dos ônus probatórios na perspectiva dos direitos fundamentais. Tese (Mestrado), Faculdade de Direito, Universidade Federal do Rio Grande do Sul, 2008, p.38.. Referiu-se o autor inicialmente a Micheli e posteriormente a Devis Echandia e a Rui Rangel.

${ }^{111}$ CARNELUTTI, Francesco. La prueba civil. Buenos Aires: Ediciones Depalma, 1982, p.117

112 Sergio Pinto Martins reconhecendo a dupla vertente do ônus da prova assim conceitua expressamente os institutos: O Ônus da prova subjetivo consiste em verificar quem entre os sujeitos do processo deve fazer a prova. O ônus objetivo diz respeito ao magistrado, que irá verificar a prova constante dos autos, independentemente de quem tenha o ônus da prova; apresentada a prova nos autos o juiz deverá levá-la em consideração, independentemente de quem tenha tido o ônus. In MARTINS, Sérgio Pinto. Direito processual do trabalho. São Paulo: Atlas, 2000, p. 284. 
O ônus da prova na visão clássica ou tradicional ${ }^{113}$ tem sido tomado mais como um encargo da parte do que como um direito ou poder das partes ${ }^{114}$, o que levou alguns juristas a exemplo de Flávio Yarshell a reconhecer que essa qualificação sob uma perspectiva negativa fosse "insuficiente para explicar sua dimensão positiva no contexto das garantias constitucionais, enfeixadas pela garantia síntese que é o devido processo legal. "115

Contudo mesmo a perspectiva negativa da ideia de ônus e ligada, repita-se, a uma abordagem mais tradicional vem se transformando, mormente após a constitucionalização das garantias processuais que tomaram termo no pós-guerra em sucessivas e importantes declarações de direitos. Passa-se a enxergar mais preponderantemente o espectro positivo do ônus da prova, ou melhor, compreendê-la, nas palavras de Cambi, sob uma "ótica positiva" a partir do momento em que o direito à prova passa a representar, no constitucionalismo, um direito primordial das partes inclusive com tutelas específicas. Segundo o autor "essa moderna compreensão dos problemas probatórios denota a insatisfatória visão que a noção de ônus da prova tem com relação à correta reconstrução dos fatos no processo, que é um dos pressupostos para a justiça da decisão" 116

\footnotetext{
${ }^{113}$ Quando nos referirmos à propalada perspectiva tradicional do ônus da prova teremos em mente a regra como atualmente positivada seja no Código de Processo Civil que no art. 333 determinada que prova incumbe: I - ao autor, quanto ao fato constitutivo do seu direito; II - ao réu, quanto à existência de fato impeditivo, modificativo ou extintivo do direito do autor. Não menos presente nessa perspectiva clássica igualmente no direito processual do trabalho que tem na maioria dos seus intérpretes, como se verá em item próprio, a ideia de aplicação do instituto subsidiariamente à regra do art.818 da Consolidação das Leis do Trabalho (art. 818- A prova das alegações incumbe à parte que as fizer)

${ }_{114}$ A discrepância entre os doutrinadores clássicos existe, posicionando-se pela classificação do ônus da prova como um dever, estão doutrinadores do nível de Carnellutti e Couture e classificando-o como poder, direito ou faculdade podemos citar Echandia, Rosenberg e Micheli em suas obras respectivamente: CARNELUTTI, Francesco. Teoria general Del derecho, apud Roland Arazi, ARAZI, Roland. La prueba en el proceso civil. $2^{\mathrm{a}}$ edição. Buenos Aires: Ediciones La Rocca, 1998, p.88, COUTURE, Eduardo Juan. Fundamentos do Direito Processual Civil.(trad. Rubens Gomes de Sousa). São Paulo: Saraiva, 1946, p.143,DEVIS ECHANDÍA, Hernando. Teoria General De La Prueba Judicial. Buenos Aires: Zavalia,1981, 415; ROSENBERG, Leo. La Carga de La Prueba. Traducción de Ernesto Krotoschin. Buenos Aires : Editorial B de f, 2002, p.49 e seguintes.

115 YARSHELL, Flávio Luiz. Antecipação da Prova sem o requisito da urgência e o Direito Autônomo à Prova. São Paulo: Editora: Malheiros, 2009, p.47

${ }^{116}$ CAMBI, Eduardo Augusto Salomão. Direito Constitucional à Prova no Processo Civil. São Paulo: Revista dos Tribunais, 2001, pp.43-44
} 
Ônus subjetivo liga-se à percepção das regras do ônus da prova mais como uma regra de conduta direcionada às partes e indicativa dos fatos que cada um tem que provar. Mesmo que as partes não consigam desincumbir-se desse encargo, o juiz deverá julgar ante a vedação do non liquet, e se configurando esta hipótese emergiria a face do ônus objetivo da prova. ${ }^{117}$

Barbosa Moreira com toda a clareza que lhe é peculiar é capaz, de em poucas palavras definir o complexo fenômeno do ônus subjetivo da prova nos seguintes termos: "o desejo de obter a vitória cria para o litigante a necessidade, antes de mais nada, de pesar os meios de que se poderá valer no trabalho de persuasão, e de esforçar-se, depois, para que tais meios sejam efetivamente utilizados na instrução da causa. Fala-se, ao propósito, de ônus da prova num primeiro sentido". 118

Relativamente ônus objetivo, sua denominação como tal tem sido atribuída a um aspecto primordial do ônus da prova, a saber, sua configuração como regra de julgamento que determina a decisão judicial ainda que não haja elementos probatórios suficientes para a convicção do juiz ${ }^{119}$. Oportuno assinalar, portanto no que toca ao ônus objetivo, que as consequências da prova frustrada, não correspondem a uma sanção, mas a um prejuízo que eventualmente pode atingir o litigante sucumbente.

Valho-me, ainda desta feita, da precisão dos conceitos de Barbosa Moreira, tomando-o também em relação ao ônus objetivo da prova: "A circunstância de que, ainda assim, o litígio deva ser decidido torna imperioso que alguma das partes suporte o risco inerente ao mau êxito da prova. Cuida então a lei, em geral, de proceder a uma distribuição de riscos: traça critérios destinados a indicar, conforme o caso, qual dos litigantes terá de suportálos, arcando com as consequências desfavoráveis de não se haver provado o fato que lhe

\footnotetext{
117 DIDIER JR, Fredie; BRAGA, Paula Sarno; OLIVEIRA, Rafael. Curso de Direito Processual Civil vol.2. Salvador: Juspodivm, 2009, p.73

${ }^{118}$ BARBOSA MOREIRA, José Carlos. Julgamento e ônus da prova. In Temas de Direito Processual: segunda série. Saraiva, 1988. pp.74-75
} 
aproveitava. Aqui também se alude ao ônus da prova, mas num segundo sentido (ônus objetivo ou material)". ${ }^{120}$

Não há como negar o aspecto objetivo do ônus da prova, pois na perspectiva do processo acaba por não interessar, no final, quem produziu a prova (princípio da aquisição ou da comunhão de provas). O destaque da dimensão objetiva do ônus da prova se dá muito pela constatação de sua função também de garantia em face do arbítrio judicial ao pretender impor um parâmetro racional para que seja proferida decisão mesmo em caso de dúvida ou insuficiência de prova.

Conferindo total primazia ao aspecto regra de juízo Verdi dedica todo o capítulo primeiro de sua obra a tal justificação, afirmando expressamente que "si può, allora, cominciare a credere che l'esigenza di uma regola di giudizio nasce non dal bisogno di auorizzare il giudice a decidere nel merito anche in caso di incertezza sul fatto, ma dalla convinzione che sai necessaria un'apporsita regola per rendere possibile al giudice di pronunciare il rigetto delle richieste i cui presupposti di fatto non siano provati "121

No que tange à distinção entre o ônus subjetivo e objetivo da prova, didática é aquela apresentada por Luiz Eduardo Boaventura Pacífico ao indicar que o primeiro diz respeito à produção de provas pelas partes nos termos do artigo 333 do Código de Processo Civil, enquanto que o segundo tem sua base no artigo 131 do mesmo diploma, equivalente à própria regra de julgamento a ser aplicada pelo juiz quando colocado diante de uma situação de dúvida ou incerteza. Continua o mesmo autor, esclarecendo que o ônus subjetivo "identifica-se com a necessidade de as partes fornecerem as provas dos fatos relevantes em seu favor", sob pena de sucumbirem, prerrogativa esta que serve inclusive como estímulo à atividade probatória, vez que o objetivo máximo do ator processual consiste em, por meio da persuasão, convencer o Juiz da veracidade do fato alegado. Ressalta, por fim, que atrelada à

\footnotetext{
${ }^{119}$ PACÍFICO, Luiz Eduardo Boaventura. O ônus da prova no direito processual civil. Dissertação (Mestrado), Faculdade de Direito, Universidade de São Paulo. São Paulo, 1998, p. 168

${ }^{120}$ BARBOSA MOREIRA, José Carlos. op.cit.. pp.74-75

${ }^{121}$ VERDE, Giovanni. L'onere della prova nel processo civile. Napoli: Jovene, 1974, p.27
} 
atividade probatória das partes, consistente, repita-se, nessa dimensão subjetiva, encontra-se a dimensão objetiva, que em resumo consiste no "risco da prova frustrada", ou seja, prova inexistente ou insuficiente leva ao julgamento do mérito de qualquer forma, diante da inafastabilidade da jurisdição. O juiz somente se preocupará, sob este aspecto, no momento de sentenciar. Este segundo aspecto do ônus da prova tem sido considerado como a própria essência do instituto do ônus da prova. ${ }^{122}$

Registre-se que a ênfase para o aspecto objetivo do ônus da prova é tecnicamente correta, mas deve ser dado também o devido realce ao aspecto subjetivo do encargo uma vez que é ele que estabelece um vínculo muito importante entre a prova e os sujeitos parciais. Todavia não há como negar um aspecto objetivo às regras de distribuição do ônus da prova.",123

Autores há, entretanto, que criticam a própria utilidade da distinção das dimensões objetiva e subjetiva do ônus da prova, pois ao final da instrução pouco importaria quem trouxe a prova aos autos, impondo-se ao juiz a apreciação de todo o arcabouço probatório produzido. Em síntese seria suficiente ao magistrado a verificação quanto à completude da instrução, ou seja, realizadas as provas, pouco importa quem as produziu, lançando-se o julgamento aos autos. A questão fundamental se daria caso fosse incompleto o resultado da instrução, quando então o juiz irá ater-se à dimensão objetiva do onus probandi, questionando acerca da responsabilidade pela falta da prova para que venha a parte inerte a suportar eventual prejuízo correspondente. Logo não importaria quem produziu a prova, mas o que acabou por ficar provado. ${ }^{124}$

A dissensão quanto à relevância dos aspectos do ônus da prova também existe na será trabalhista. Manoel Antonio Teixeira Filho sequer vislumbra o aspecto objetivo

\footnotetext{
${ }^{122}$ PACÍFICO, Luiz Eduardo Boaventura. O ônus da prova no direito processual civil. Dissertação (Mestrado), Faculdade de Direito, Universidade de São Paulo. São Paulo, 1998, pp.167-178

${ }^{123}$ YARSHELL, Flávio Luiz. Antecipação da Prova sem o requisito da urgência e o Direito Autônomo à Prova. São Paulo: Editora: Malheiros, 2009, pp.56-57

${ }^{124}$ DIDIER JR, Fredie; BRAGA, Paula Sarno; OLIVEIRA, Rafael. Curso de Direito Processual Civil vol.2. Salvador: Juspodivm, 2009, pp.74-75
} 
do ônus voltado para o juiz pois este ao apreciar a prova poderá valer-se do critério do livre convencimento motivado. ${ }^{125}$

Por outro lado Mauro Schiavi dá relevo à perspectiva do ônus da prova como regra de julgamento, afirmando que o juiz só usará o ônus da prova quando não houver nos autos provas ou como critério para desempate. ${ }^{126}$ Com posição similar o autor Adalberto Martins considera a utilidade prática das regras do ônus da prova quando da prolação da sentença se a prova não foi produzida ou não foi suficiente. ${ }^{127}$

Entretanto, há que se ter efetivamente a compreensão das duas perspectivas (subjetiva e objetiva) cuja importância é impar para que se considerem quem são efetivamente os destinatários das normas referentes ao ônus da prova ${ }^{128}$. Pensando-se sob o ponto de vista da partes é possível dar resposta a questões acerca do momento processual de atribuição do ônus e até mesmo a quem (lei ou juiz) é possível modificar regras do encargo probatório. No caso da distribuição dinâmica do ônus da prova a dimensão subjetiva nos dá, portanto, subsídios para responder a essas perguntas e um exemplo concreto se dá pela tendência entre os doutrinadores de imputação de ônus em momento próprio a possibilitar o contraditório às partes.

\footnotetext{
${ }^{125}$ Pela dissensão, oportuno citar a opinião do processualista trabalhista Manoel Antonio Teixeira Filho para quem não há propriamente um ônus objetivo: “...não nos parece ser possível sustentar-se a afirmação de que há um ônus objetivo voltado para o Juiz, quando se sabe que, na apreciação da prova, o julgador deverá valer-se de certos critérios de avaliação (e o nosso sistema consagrou o da persuasão racional ou do livre convencimento motivado), sendo assim, inadmissível supor-se que esse critério constitua, no caso, um ônus segundo a acepção que o vocábulo sugere à ciência jurídica processual. Por outra parte, cremos que, se não como regra genérica, ao menos em determinadas hipóteses, deve o Juiz levar em consideração quem produziu a prova"(...) Por fim, não nos parece que ônus, em relação às partes seja subjetivo; trata-se, a nosso ver, de ônus nitidamente objetivo, vez que oriundo de disposição legal específica; vale dizer, porque fixado pelo direito positivo processual. A objetividade, assim, se relaciona à distribuição da carga da prova, feita por lei, e não á pessoa do Juiz: e em que pese essa participação legal do ônus tenha como destinatários os litigantes, nem por isso se pode afirmar que ele seja subjetivo". A prova no processo do trabalho. São Paulo: LTr, 2003, pp.118-119. Posição mantida no Curso de Direito Processual do trabalho. São Paulo: LTr, 2009 Volume II, pp. 972-973.

${ }^{126}$ SCHIAVI, Mauro. Manual de direito Processual do Trabalho. São Paulo: LTr, 2009 p.522.

${ }^{127}$ MARTINS, Adalberto. Manual Didático de Direito Processual do Trabalho. 4a. Edição. Malheiros, São Paulo, 2008. pp. 160-161

${ }^{128}$ YARSHELL, Flávio Luiz. Antecipação da Prova sem o requisito da urgência e o Direito Autônomo à Prova. São Paulo: Editora: Malheiros, 2009, p.49
} 
Sob a perspectiva das partes representará o ônus da prova uma a posição jurídica voltada para um interesse próprio. Sob a perspectiva objetiva o destinatário da prova passa a ser o juiz que necessita dela para descoberta da verdade atendendo, portanto, a um interesse público no proferimento de decisões mais justas. ${ }^{129}$

Associando-se essa dicotomia entre as duas dimensões do ônus da prova com a problemática das cargas probatórias dinâmicas, as preocupações tomam maior relevo mormente diante das garantais constitucionais do processo. Considerando-se o ônus objetivo e o subjetivo em que momento o juiz irá atribuir o encargo da prova à parte que não o detinha pelas regras clássicas - na instrução (subjetivo) ou no julgamento (objetivo)? No particular ao se levar em conta os poderes de instrução do juiz o problema perde um pouco do seu relevo na medida em que o magistrado utilizando-se dessa prerrogativa acaba por diminuir a influência do aspecto subjetivo do ônus da prova ao tomar para si iniciativas na esfera probatória. Passase, pois, no próximo tópico a abordar algumas questões relativas aos poderes instrutórios do juiz.

\section{Os poderes instrutórios do juiz}

A transformação na sociedade trazida pelo Estado Democrático de Direito implicou diretamente num compromisso para a concretização de direitos, na maior medida possível e com isso deu-se uma maior destaque à função jurisdicional. Ganhou força, portanto, a atuação do juiz inclusive na esfera probatória como positivado expressamente no art.130 do CPC bem assim nos art.765 e 852-D da CLT ${ }^{130}$.

\footnotetext{
${ }^{129}$ Idem. Ibidem. p.50

${ }^{130}$ Art. 130 do CPC:. Caberá ao juiz, de ofício ou a requerimento da parte, determinar as provas necessárias à instrução do processo, indeferindo as diligências inúteis ou meramente protelatórias.

Art.765 da CLT- Os Juízos e Tribunais do Trabalho terão ampla liberdade na direção do processo e velarão pelo andamento rápido das causas, podendo determinar qualquer diligência necessária ao esclarecimento delas.

Art.852-D da CLT - O juiz dirigirá o processo com liberdade para determinar as provas a serem produzidas, considerado o ônus probatório de cada litigante, podendo limitar ou excluir as que considerar excessivas, impertinentes ou protelatórias, bem como para apreciá-las e dar especial valor às regras de experiência comum ou técnica.
} 
Configura-se a partir da evolução constitucional uma nova visão da atividade do juiz a quem se atribui papel dominante na direção do processo concomitante com a atividade colaborativa das partes no que tange à instrução processual. Consigne-se, outrossim, que as necessidades sociais próprias do direito do trabalho repercutem na sua vertente processual impondo um tratamento processual que implemente e concretize o ideário deste ramo especial do direito.

Barbosa Moreira partindo inclusive de uma ideia muito interessante sobre os papéis complementares entre juiz e partes no processo, bem delimita a questão, ao asseverar que "em matéria de prova, enfim deveria ser claro que nenhuma intensificação da atividade oficial, por mais "ousada" que se mostre, tornará dispensável, ou mesmo secundária, a iniciativa dos litigantes. De maneira alguma se trata de cerceá-la como dão a impressão de temer alguns intransigentes críticos do processo "inquisitório" - outra denominação bastante equívoca. O papel do juiz e o das partes são aqui complementares; absurdo concebê-los como reciprocamente excludentes. E não custa reconhecer que, de fato, ao menos não comum dos casos, por óbvias razões, dos próprios litigantes é que se obterá, com toda a probabilidade, aporte mais substancioso." 131

Registre-se, inclusive, que o reconhecimento de poderes instrutórios ao juiz representou um abalo na concepção subjetiva do ônus da prova, sendo certo entretanto que a doutrina tem sustentado efetivamente a possibilidade de investigação de provas pelo juiz, independentemente se tratarem-se de fatos constitutivos do direito do autor ou se fatos extintivos, impeditivos ou modificativos. ${ }^{132}$

Classicamente predominava em matéria de prova o princípio dispositivo restringindo-se os poderes dos juízes na condução do processo. Sob este prisma a iniciativa do magistrado era apenas suplementar, mas atualmente embora o encargo da prova caiba as

\footnotetext{
${ }^{131}$ BARBOSA MOREIRA, José Carlos. A função social do processo civil moderno e o papel do juiz e das partes na direção e instrução do processo. In Revista de Processo São Paulo no. 37, jan/março de 1985 p.148

${ }^{132}$ PACÍFICO, Luiz Eduardo Boaventura. op.cit. pp.184-185. Neste ponto o autor refere-se ao reconhecimento dos poderes instrutórios do juiz por abalizados doutrinadores como Cândido Rangel Dinamarco, José Carlos Barbosa Moreira e José Roberto dos Santos Bedaque.
} 
partes, o interesse na produção das provas é público, ou seja, o Estado na figura do juiz tem interesse, para formação de seu convencimento, que seja produzido o mais amplo espectro de provas sobre os fatos deduzidos nos autos. Pode, inclusive, com observância das garantias constitucionais do processo, determinar provas de ofício. Isto como natural decorrência do reconhecimento do processo como tendo uma natureza pública, não se confundindo com os interesses materiais privados que ali estejam sendo discutidos.

A ideia dessa ampliação de atuação do juiz também é a de restabelecer uma situação de igualdade substancial das partes em sede probatória. A propósito Bedaque bem explica a questão:

"Entre as regras que não asseguram a real igualdade entre os litigantes, encontra-se a da plena disponibilidade das provas, reflexos de um superado liberalindividualismo, que não mais satisfaz as necessidades da sociedade moderna, pois pode levar as partes a uma atuação de desequlíbrio substancial. Muitas vezes sua omissão na instrução do feito se deve a fatores econômicos ou culturais e não à intenção de dispor do direito.

Para evitar essa situação, várias medidas vêm sendo adotadas pelo legislador processual. Dentre elas, vislumbra-se o reforço do poder instrutório do juiz. A cada dia aumenta o número de defensores da ideia de que somente um comportamento ativo do julgador faz com seja respeitado um dos princípios processuais de maior relevância social: o da igualdade real entre as partes. Trata-se de poderoso instrumento que o magistrado tem em suas mãos, que lhe possibilita corrigir as desigualdades econômicas presentes na relação processual".

Registre-se por fim que mesmo essa ampliação nos poderes de instrução do juiz não gera a perda de sua imparcialidade. Essa conclusão é mais precisa inclusive em relação a situações de direito material que exigem ainda mais posturas ativas do magistrado aptas à superação dos obstáculos externos ou fatores adversos que impossibilitam as partes de trazer aos autos as provas pertinentes e relevantes para a obtenção de uma decisão justa, caso típico das demandas trabalhistas. Ademais o próprio aprofundamento na pesquisa e colheita de provas só beneficia a parte que efetivamente tem razão. ${ }^{133}$

\footnotetext{
${ }^{133}$ A propósito a pergunta de Bedaque: "Não seria parcial o juiz que, tendo conhecimento de que a produção de determinada prova possibilitará o esclarecimento de um fato obscuro, deixe de fazê-lo e, com tal atitude, acabe beneficiando a parte que não tem razão? In. Poderes instrutórios do juiz. São Paulo: Revista dos Tribunais, 2001, p.108.
} 
Exigir a condição de mero expectador do processo, impondo somente às partes o encargo da prova, importa no próprio ferimento grave a outros princípios, pois se a jurisdição, como também o processo tem seus escopos, devem ser reconhecidos ao magistrado amplos poderes instrutórios para que cumpra adequadamente sua tarefa constitucional. ${ }^{134}$

Na verdade o controle da imparcialidade de um juiz se dá justamente por meio da fundamentação e publicidade de suas decisões e não lhe negando poderes instrutórios. Cientificando-se as partes quanto às provas, seus encargos e dando-lhes possibilidade de participação pelo contraditório, há que se sepultar qualquer dúvida em relação ao ânimo do juiz.

Luigi de Ítala, sob a perspectiva do processo do trabalho italiano da época, ao tratar da questão dos poderes inquisitórios do juiz do trabalho durante a instrução do processo e seus limites, já questionava se o legislador tencionara atribuir ao juiz um poderdever à semelhança do processo penal em que vige plenamente o princípio inquisitório ou apenas estaria a conferir ao juiz do trabalho um poder integrador da atividade processual das partes. Concluiu o autor italiano que ao aumentar os poderes do juiz a lei processual do trabalho quisera conceder um poder discricionário na iniciativa processual, inclusive com os poderes instrutórios que considerasse necessários embora não houvesse sido abolido completamente o princípio dispositivo. ${ }^{135}$

A situação não é diferente hoje no processo do trabalho que em face da amplitude da disposição prevista no art.765 da CLT $^{136}$ o juiz detém amplos poderes

\footnotetext{
${ }^{134}$ MARINONI, Luiz Guilherme; ARENHART, Sérgio Cruz. Manual do Processo de Conhecimento. São Paulo: Revisa dos Tribunais 2004

${ }^{135}$ ITALA, Luigi de. Diritto Processuale Del Lavoro. Torino: Editrice Torine,1966, p.303

136 Ísis de Almeida a propósito do art.765 da CLT: "O juiz, como tanto já se tem apregoado, não é mero espectador de uma luta, especialmente no processo trabalhista, em que o princípio inquisitório é tão enfatizado e autoriza uma intervenção dele, ampla e profunda, na lide (cf.art.765 da CLT). Ele vai, até onde queira ir, em busca da verdade. Só deve respeitar é a igualdade no tratamento das partes; a imparcialidade no procedimento, quando às medidas a tomar, às diligências a ordenar" In. Manual de Direito Processual do Trabalho. $2^{\circ}$.vol. São Paulo: LTr, 1997, p.138
} 
instrutórios. A propósito verifica-se com nitidez a tendência de alargamento dos poderes probatórios do juiz do trabalho a partir inclusive da edição do art.852-D da CLT ao prever que “o juiz dirigirá o processo com liberdade para determinar as provas a serem produzidas, considerado o ônus probatório de cada litigante, podendo limitar ou excluir as que considerar excessivas, impertinentes ou protelatórias, bem como para apreciá-las e dar especial valor às regras de experiência comum ou técnica" (g.n.).

Márcio Túlio Viana, ao tratar da norma em tela, vislumbrou inclusive uma ênfase ao próprio princípio inquisitório, mais latente no processo do trabalho, significando, para o autor, "um juiz mais vivo, mais presente, mais participante, mais comprometido com a verdade real". 137

\section{Positivação das regras sobre o ônus da prova no processo civil}

\subsection{O Código de Processo Civil e a regra estática do artigo 333.}

O artigo 333 do Código de Processo Civil institui as regras sobre a distribuição do ônus probatório distribuindo sua incumbência e encontrando-se atualmente positivado nos seguintes termos:

“Art. 333 - O Ônus da prova incube:

I - ao autor, quanto ao fato constitutivo do seu direito;

II - ao réu, quanto à existência de fato impeditivo, modificativo e extintivo do direito do autor.

Parágrafo único: É nula a convenção que distribui de maneira diversa o ônus da prova quando:

I - recair sobre direito indisponível da parte;

II - tornar excessivamente difícil a uma parte o exercício do direito"

\footnotetext{
${ }^{137}$ VIANA, Márcio Túlio Aspectos polêmicos da prova no rito sumaríssimo. In: Paiva, Mário Antônio Lobato de, 1975- (coord.). A lei do rito sumaríssimo e das comissões de conciliação prévia na justiça do trabalho vistas pelos juristas. Rio de Janeiro: Forense, 2002. pp.45-52
} 
Trata-se do sistema legal, estabelecendo as regras referentes ao ônus da prova por meio do qual competirá ao autor demonstrar o fato constitutivo de seu direito e ao réu os fatos modificativos, extintivos ou impeditivos daquele direito. Em outras palavras, a cada parte cabe o ônus de provar os pressupostos fáticos do direito cujo reconhecimento pretende do juiz ao solucionar a controvérsia. Levou em conta o legislador dois elementos, quais sejam, a natureza dos fatos e a posição processual das partes.

Bedaque fazendo referência à Chiovenda bem sintetiza a natureza desses fatos ao ensinar que "fato constitutivo é aquele que dá vida a uma vontade concreta da lei, que tem essa função específica e que normalmente produz esse efeito. Extintivo, porque faz cessar essa vontade. Impeditivo é inexistência do fato que deve concorrer com o constitutivo, a fim de que ele produza normalmente os seus efeitos; enquanto o fato constitutivo é causa eficiente, o impeditivo é a ausência de uma causa concorrente" 138

Embora neste projeto pretendamos a superação, no processo do trabalho, da aplicação formalista do art.333 do CPC (atente-se, superação, não negação total), não podemos deixar de concordar com o reconhecimento da importância dessa previsão legal para o sistema processual civil e trabalhista na medida em que estabelece uma regra precisa sobre a atribuição desses ônus, tratando-se de indicativo a partir da natureza dos fatos que traduzem a realidade da vida dos sujeitos em disputa. Dispositivo este que se apresenta com técnica qualitativamente superior àquela prevista pelo Código de Processo Penal ${ }^{139}$ que indica apenas o ônus de provar o fato alegado. ${ }^{140}$

Registre-se aqui que também a CLT apresenta tal técnica, o que para muitos é simplista, não sendo capaz de abranger toda a complexidade da matéria dos ônus

\footnotetext{
${ }^{138}$ BEDAQUE, José Roberto dos Santos. Poderes instrutórios do juiz. São Paulo: Revista dos Tribunais, 2001, p.114

${ }^{139}$ Art. 155 do Código de Processo Penal: “Art. 156. A prova da alegação incumbirá a quem a fizer, sendo, porém, facultado ao juiz de ofício: I - ordenar, mesmo antes de iniciada a ação penal, a produção antecipada de provas consideradas urgentes e relevantes, observando a necessidade, adequação e proporcionalidade da medida; II - determinar, no curso da instrução, ou antes de proferir sentença, a realização de diligências para dirimir dúvida sobre ponto relevante.
} 
probatórios; simplicidade, esta, que para nós, por exemplo, consubstanciará uma menor resistência à adoção da carga probatória dinâmica.

Verifica-se que o Código de Processo Civil não impõe a obrigação de produzir a prova, apenas indicando a quem cabe o encargo da comprovação dos fatos alegados, a partir da natureza desses mesmos fatos bem assim da posição em que cada uma das partes encontra-se no processo, o que vem em consonância com o referencial teórico clássico em torno da questão, ou seja, não imputa uma pena às partes pela inércia ou ainda um prejuízo inexorável ao direito pretendido. As partes simplesmente assumem o risco de não realizar a prova do seu direito (das questões fáticas em que ele se calca) e em consequência obter um julgamento desfavorável aos seus interesses.

$\mathrm{Na}$ verdade a própria razão de ser da regra de distribuição do ônus da prova está ligada a também a uma questão de equidade porquanto às partes em litígio deve-se darlhes igualmente a palavra, de modo que também ao atribuir-lhes os ônus, estes devem atingir a ambas. $^{141}$

Outra questão importante a referir diz respeito à conjunção da previsão prevista no art. 333 do CPC com o art.130 do mesmo Código, vez que a doutrina costuma visualizá-los conjuntamente para admitir a intervenção do juiz apenas se conforme com as regras de distribuição, não servindo para suprir a inércia da parte na apresentação de prova que lhe competia, de modo a representarem, aquelas regras, verdadeiro limite aos poderes do juiz. ${ }^{142} \mathrm{Ou}$ seja, se a prova de uma das partes for insuficiente ou nula não será permitido ao magistrado, por conta até mesmo do disposto no art.125, I do CPC, providenciar de oficio a satisfação dessa prova, sob pena de quebra, inclusive do dever de imparcialidade.

\footnotetext{
${ }^{140}$ BEDAQUE, José Roberto dos Santos. Poderes instrutórios do juiz. São Paulo: Revista dos Tribunais, 2001, p. 115

${ }^{141}$ CINTRA, Antonio Carlos; GRINOVER, Ada Pellegrini; DINAMARCO, Cândido Rangel. Teoria Geral do Processo. São Paulo:Malheiros, 1995, p.352.

${ }^{142}$ BEDAQUE, José Roberto dos Santos. Poderes instrutórios do juiz. São Paulo: Revista dos Tribunais, 2001, p.116
} 
Mas tal raciocínio, contemporaneamente, e a partir da nova conotação do processo, em especial da pretensão de efetividade desse instrumento, não parece correto. A propósito Bedaque critica esse posicionamento com base no reconhecimento da efetividade do processo como "um dos mais eficazes fatores de harmonia social", e após a consideração das regras de ônus da prova como regras de julgamento entende justamente a partir dessa visão objetiva que o juiz antes desse último momento não tem que se preocupar com tais regras incumbindo-lhe utilizar os meios possíveis para que de fato sua decisão venha a retratar a realidade fática. Incidem as regras, portanto e ao final apenas para evitar o non liquet, representando, isto sim, uma última saída ao magistrado que não tem como se omitir na decisão. $^{143}$

Logo, embora o interesse das partes na produção das provas seja inarredável fato é que o juiz deve providenciar a realização das provas que entenda necessárias objetivando atender o fim último da jurisdição que é o julgamento justo ${ }^{144}$.

A discriminação do ônus da prova pelo art.333 do CPC conforme a concepção clássica seria objetiva e fixa, vinculando-se à atividade das partes em prol da consecução de seus direitos. Incumbência "individual" da parte que é "responsável" por provar suas alegações. Não levou em conta, portanto, as especificidades dos casos concretos e nada obstante a idealização da previsão legal se coadune com o princípio constitucional da segurança jurídica, em determinadas situações poderá se mostrar extremamente difícil ou impossível a uma pessoa realizar a prova de suas alegações.

Como bem adverte Marcelo Abelha Rodrigues,

“a regra de distribuição do ônus da prova na forma mencionada está vinculada à ideologia de um Estado Liberal, porque é o aspecto subjetivo da prova que delimita a atuação e contornos do aspecto objetivo da prova, ou seja, a contrario sensu, o

\footnotetext{
${ }^{143}$ Idem.Ibidem. pp.118-119

${ }^{144}$ Registre-se, a propósito a constatação de Bedaque: "Dentre todas as frustrações que a jurisdição pode causar às pessoas, a mais grave, sem dúvida, é a emissão de um provimento injusto. E, normalmente as injustiças são cometidas contra aqueles que, pro razões econômicas, não tem condições de se apresentar de igual para igual no processo" (negritei). In: Poderes..., p.122
} 
juiz não pode deixar de julgar alegando falta ou insuficiência de prova, conquanto caiba às partes, precipuamente, o encargo de municiá-lo sobre as provas que servirão à formação do seu convencimento. Assim, se as partes não oferecem subsídios - e este é um problema que lhes pertence, segundo o estado Liberal -, deve assim mesmo o juiz julgar, formando seu convencimento sobre o material probatório que lhe foi fornecido. A busca e a investigação da prova pelo próprio juiz são algo excepcional e subsidiário no direito processual civil tradicional" 145

Em relação à regra como presente hoje no sistema processual tem-se que ao distribuir os encargos ${ }^{146}$ conforme a classificação dos fatos apresenta-se, na lição de Marinoni e Arenhart, como um mecanismo artificial, comprometido com uma natureza universalista do procedimento ordinário que não atenta para as ocorrências do direito material ao distribuir os riscos do processo. Assim é regra descomprometida com a realidade da vida.

Partiu o regramento processual civil da suposição da igualdade formal das partes de modo que ao autor caberia a prova dos fatos constitutivos de seu direito como condição de atuação concreta da lei a amparar a sua pretensão. E o réu ao opor a esses fatos outros aptos à sua extinção, impedimento ou modificação atrairia para si o encargo da prova de tais alegações, pressupondo a propalada igualdade jurídica formal. ${ }^{147}$

Com efeito, as peculiaridades das situações do plano do direito material não podem ser desconsideradas no momento de atribuição do ônus da prova. E a solução hoje, a vista da regra estática, passa pela utilização das presunções legais relativas, as quais representariam importante saída posto que ligadas diretamente a certas situações de direito substancial que podem levar a uma redistribuição dos encargos, sua inversão ou atenuação do seu rigor. Por fim, ainda para Marinoni e Arenhart não há qualquer empecilho a que,

145 RODRIGUES, Marcelo Abelha. A distribuição do ônus da prova no Anteprojeto do Código Brasileiro de Processos Coletivos. In: GRINOVER, Ada Pellegrini Grinover; MENDES, Aluisio Gonçalves de Castro; WATANABE, Kazuo (coords.). Direito Processual Coletivo e o Anteprojeto de Código Brasileiro de Processos Coletivos. São Paulo: Revista dos Tribunais, 2007, p.244.

146 MARINONI, Luiz Guilherme; ARENHART, Sérgio Cruz. Prova. São Paulo: Revista dos Tribunais, 2007, p.167

147 TEIXEIRA FILHO, Manoel Antonio. Curso de Direito Processual do trabalho. Vol.II São Paulo: LTr, 2009, p.973 
considerada uma situação peculiar de direito material, seja atribuído o ônus da prova de forma diferente pelo juiz desde que fundamente seu procedimento. ${ }^{148}$

Entretanto essa regra absoluta de divisão do ônus da prova não mais se sustenta no próprio processo civil diante das transformações da sociedade e do reconhecimento constitucional da isonomia real das pessoas. Daí a necessária atuação concreta do juiz na busca também pela prova que lhe possibilitará a formação da convicção, trazendo como resultado último e esperado a resolução do conflito.

Essa insuficiência da regra do art.333 do CPC já vinha sendo reconhecida pelos processualistas e um divisor de águas na matéria foi representado pelo advento do Código de Defesa do Consumidor que positivou regras processuais autorizadoras da flexibilização do ônus da prova.

\subsection{Código de Defesa do Consumidor e a inversão do ônus da prova}

O objetivo primordial da prova é trazer a realidade para o processo. Todavia, situações particulares e próprias das relações jurídicas materiais podem representar obstáculos em relação a esse desiderato. Atento o legislador a essas condições e verificada a necessidade de adequação das regras de distribuição do ônus da prova as situações concretas subjacentes a relações jurídicas de direito material em que a característica era a assimetria entre as partes litigantes, foi prevista no Código de Defesa do Consumidor regra especial nos seguintes termos:

Art. $6^{\circ}$ São direitos básicos do consumidor:

VIII - a facilitação da defesa de seus direitos, inclusive com a inversão do ônus da prova, a seu favor, no processo civil, quando, a critério do juiz, for verossímil a alegação ou quando for ele hipossuficiente, segundo as regras ordinárias de experiências;

148 Idem. Ibidem. pp.167-168 
Há duas condicionantes, não cumulativas ${ }^{149}$, para a alteração do ônus da prova no sistema do código do consumidor: a hipossuficiência e a verossimilhança da alegação. Tratam-se de hipóteses de inversão do ônus da prova ope judicis, vale dizer, uma inversão judicial do ônus da prova na medida em que prevalece a regra do art.333 do CPC, mas o julgador, ao observar a presença de algum desses requisitos, altera a regra geral a partir da autorização dada pela regra especial.

A verossimilhança ${ }^{150}$ significa a compreensão de uma situação como plausível a partir das máximas ou regras de experiência. O juiz ao reputar verossímeis as alegações do consumidor, presume-as verdadeiras e altera o ônus da prova imputando-o ao fornecedor. Quem bem define o quesito da verossimilhança é Kazuo Watanabe ao afirmar que “o que ocorre, como bem observa Leo Rosenberg, é que o magistrado, com a ajuda das máximas da experiência e das regras da vida, considera produzida a prova que incumbe a uma das partes. Examinando as condições de fato com base nas máximas da experiência, o magistrado parte do curso normal dos acontecimentos e, porque o fato é ordinariamente a consequência ou pressuposto de um outro fato, em caso de existência deste, admite também

${ }^{149}$ DIDIER JR, Fredie; BRAGA, Paula Sarno; OLIVEIRA, Rafael. Curso de Direito Processual Civil vol.2. Salvador: Juspodivm, 2009, p.82.,com a doutrina majoritária. Reconhecem os autores expressamente que os pressupostos não são cumulativos, e sim alternativos invocando ainda nesse sentido a doutrina de Marcelo Abelha Rodrigues e Eduardo Cambi. Em posição contrária Alexandre Freitas Câmara ao entender que "Não se trata, como faz parecer o texto da lei de alternatividade. O caso é, na verdade, de cumulatividade dos requisitos. Isto porque seria absurda a ideia de se inverter o ônus da prova quando a alegação não fosse verossímil; e seria inteiramente desnecessária a inversão quando não houvesse a hipossuficiência quanto à produção da prova. A inversão baseada em apenas um desses dois requisitos certamente levaria a resultados extremamente injustos." In A inversão do ônus da prova em favor do consumidor. Revista da EMERJ, v.5, n.18, 2002, pp.98-99.

${ }^{150}$ Carlos Roberto Barbosa Moreira com a precisão peculiar integra a ideia de probabilidade ao conceito de verossimilhança para admitir a inversão da prova. Assim se expressa o autor partindo após a edição do art.273 do CPC: "Os comentadores da nova lei processual sustentam que "a verossimilhança se assenta num juízo de probabilidade, que resulta, por seu turno, da análise dos motivos que lhe serão favoráveis (convergentes) e dos que lhe são desfavoráveis (divergentes). Se os motivos convergentes são inferiores aos divergentes, o juízo de probabilidade cresce; se os motivos divergentes são superiores aos convergentes, a probabilidade diminui. Acredito ser perfeitamente possível utilizar essas noções na exegese do disposto do Código de Defesa do Consumidor: estar o juízo autorizado a inverter o ônus da prova quando formar, pelo material probatório à sua disposição no processo, a um juízo de probabilidade, de tal modo que se lhe afigure provavelmente verdadeira a alegação do consumidor" In Notas sobre a inversão do ônus da prova em benefício do consumidor. In: Revista de Processo. São Paulo: Revista dos Tribunais, no. 86, abr./jun.1997, p.303 
aquele como existente, a menos que a outra parte demonstre o contrário. Assim, não se trata de uma autêntica hipótese de inversão do ônus da prova". ${ }^{151}$

A outra hipótese de redistribuição do ônus da prova vem da verificação do quesito da hipossuficiência ${ }^{152}$ do consumidor e importa no reconhecimento de uma situação de desigualdade substancial daquele em face da outra parte da relação de consumo.

O consumidor é naturalmente a parte vulnerável desse tipo especial de relação de jurídica e essa hipossuficiência se reveste de aspectos de ordem econômica e/ou técnica decorrendo geralmente das dificuldades no acesso a informações, documentos, do grau de escolaridade da pessoa e sua posição social, poder aquisitivo e outros tantos fatos adversos que venham a impossibilitar a demonstração dos fatos alegados.

Em princípio, portanto, mesmo no sistema processual civil como um todo o ponto de partida relativo à atribuição do ônus da prova se dá pela aplicação das regras do art.333 do Código de Processo Civil e no caso desse direito especialmente tutelado que é o do consumidor, essas regras podem sofrer alteração, por decisão do juiz conferindo-se uma vantagem processual à parte hipossuficiente ou que tenha a seu lado a configuração da verossimilhança de suas alegações, de modo a garantir a equalização processual das partes em observância ao princípio constitucional da igualdade substancial. Não se olvide, contudo que se trata de hipótese que depende da verificação dos pressupostos supra, que funcionam neste caso como critérios balizadores para que o juiz determine a inversão. Aqui, por fim, cumpre registrar que por seu turno a teoria da carga dinâmica da prova privilegia também as particularidades do caso concreto, mas não partirá de critérios legais positivados para a atribuição dos encargos probatórios às partes até porque inexistentes.

151 WatANABE, Kazuo. Código de Defesa do Consumidor comentado pelos autores do anteprojeto. $5^{\circ}$. ed. São Paulo: Forense Universitária, 1998, p.617

152 Segundo Antonio Gidi “a noção de hipossuficiência está ligada à ideia de facilitação da defesa do consumidor em juízo (art. $6^{\circ}$, inc.VIII, $1^{\text {a }}$. parte, CDC) e diz respeito tanto à dificuldade econômica quanto às técnicas do consumidor, em poder desincumbir-se do ônus da prova dos fatos constitutivos do seu direito. Verificado um desses pressupostos legais, o juiz tem o dever, não a mera faculdade de inerte o ônus da prova, motivando as razões do seu convencimento (CF, art.93, inc.IX"). In Aspectos da inversão do ônus da prova no 
Outra questão ainda muito controvertida diz respeito ao momento de inversão do ônus da prova, podendo se distinguir duas grandes correntes doutrinárias a respeito. A primeira defende a redistribuição do encargo somente na sentença por parte do reconhecimento das regras do ônus da prova como regras de julgamento, de modo que somente neste momento o juiz terá condições de verificar se haverá necessidade de valer-se de tais regras para evitar o non liquet. A segunda corrente pretende a inversão por ocasião do saneamento do processo, ou seja, antes da instrução probatória, o que atenderia as próprias garantias constitucionais do processo em especial o princípio do contraditório. ${ }^{153}$

Inerente a esse questionamento, portanto, a preocupação com as garantias constitucionais mencionadas no capítulo precedente, pois ao se pretender permitir que o juiz determine no caso concreto de que forma será distribuído o ônus da prova e desta forma alterando a regra legal, poderiam ser criadas outras situações arbitrárias e por isso incompatíveis com o processo justo. Transportando esse contexto para o processo trabalhista tem-se que exercício do poder de instrução pelo juiz atenuaria consideravelmente a relevância desse questionamento do ônus da prova sob o ângulo subjetivo.

Com efeito se a partir do reconhecimento dos próprios princípios constitucionais do processo e de uma nova visão deste mesmo em prol da efetivação de decisões justas não há mais como conferir prevalência só ao aspecto objetivo do ônus da prova e assim se a idéia é munir o juiz com mais provas que propiciem essa justiça da decisão, a inversão deverá se dar em momento anterior ao julgamento e antecipada às partes para que tragam provas aos autos de modo a não haver ruptura com o devido processo legal. De fato a segunda corrente melhor se coaduna com esses propósitos mais abrangentes das regras do ônus da prova que não apenas servir de válvula de escape ao juiz em estado de dúvida ou sem material probatório convincente.

Código de Defesa do Consumidor. Revista de Direito do Consumidor. São Paulo: Revista dos Tribunais, jan/mar/1997, p.35

${ }^{153}$ CÂMARA, Alexandre Freitas. Câma. A inversão do ônus da prova em favor do consumidor. Revista da EMERJ, v.5, n.18, 2002, p.101 
Por fim, a previsão como realizada no Código de Defesa do Consumidor junge-se ao postulado constitucional da isonomia sendo importante sua referência eis que previsão paradigmática e que tem servido, por aplicação subsidiária, a proporcionar fundamentos para que se busque também no processo trabalhista a equalização substancial das partes em matéria probatória.

\section{As peculiaridades do ônus da prova no processo do trabalho}

Sob a denominação de princípio do tratamento desigual Carlos Alberto Reis de Paula após partir da observação de que o processo trabalhista vincula-se à teoria geral do processo - visão ora defendida também neste trabalho -, admite a existência de especificidades no processo laboral que o distinguem, sendo que a questão do ônus da prova seria uma dessas particularidades. ${ }^{154}$

A regência da matéria do ônus da prova não é muito diferente no processo do trabalho haja vista tratar-se um instituto processual geral. Registre-se apenas o seguinte conceito de ônus da prova no processo do trabalho:

"O ônus da prova consiste no encargo que as partes tem no processo de, não só alegar, mas de provar a verdade dos fatos por ela arrolados, se controversos. Não se trata de um dever, mas de ônus, assumindo a parte o risco de não ter êxito caso não prove os fatos alegados do qual depende a existência do direito que pretende assegurar"

No processo do trabalho a regra de ônus da prova é a prevista no art.818 da CLT, embora doutrinadores e intérpretes em sua maioria utilizem do arcabouço processual civil explicitado no art.333 do CPC, como regra de aplicação subsidiária à do art.818 da CLT

154 PAULA, Carlos Alberto Reis de. A especificidade do ônus da prova no processo do trabalho. São Paulo: LTr, 2001, p.139.

155 BEGALLES, Carlos Alberto. Lições de direito processual do trabalho. São Paulo: LTr, 2005, p.234. Para Amauri Mascaro do Nascimento "ônus da prova é a responsabilidade atribuída à parte para produzir uma prova e que, uma vez não desempenhada satisfatoriamente, traz, como consequência, o não-reconhecimento, pelo órgão 
por autorização do art.769 da CLT, ao pressuposto de que as regras celetistas seriam insuficientes para dirimir todas as questões relativas ao ônus da prova.

Preceitua o art.818 da Consolidação das Leis do Trabalho que "a prova das alegações incumbe a quem as fizer". Considerados estes termos verifica-se, que de fato, à exemplo do que ocorre com o art.333 do CPC também a CLT não considera, por meio da leitura isolada deste dispositivo, as possíveis desigualdades provenientes de fatores externos ao processo e de ordem material. Desta forma, as críticas já postas sob este prisma se repetiriam em face do art.818 da norma processual trabalhista. Ao contrário, se partíssemos de uma interpretação sistemática, ou seja, compreendendo-se o artigo 818 como uma norma processual aberta ${ }^{156}$ e como tal pronta a ser completada em seu conteúdo, a problemática do encargo da prova seria minimizada. Todavia o assunto será aprofundado no último capítulo até mesmo como um dos fundamentos autorizadores da compreensão quanto à aplicabilidade da teoria dinâmica da carga da prova no processo do trabalho.

Uma questão é clara - o art. 818 da CLT, numa visão não sistemática como regra de atribuição do ônus da prova ${ }^{157}$ se mostra insuficiente e inadequado ${ }^{158}$ aos fins do

jurisdicional, da existência do fato que a prova destina-se a demonstrar". In. Curso de Direito Processual do Trabalho. São Paulo: Saraiva, 1994, p. 267

${ }^{156}$ A propósito da necessidade de nova interpretação do art.818 da CLT, Manoel Antonio Teixeira Filho já afirmava que "a grande tarefa da doutrina trabalhista brasileira, que tanto se tem empenhado em cristalizar o princípio da inversão do ônus da prova, em benefício do trabalhador - cuja preocupação tem unido pensadores em diversos países - consistirá em encontrar, no próprio conteúdo do art.818 da CLT, os fundamentos que até então vem procurando, abstratamente, para dar concreção ao princípio da inversão do encargo da prova em prol do trabalhador. Vale dizer: o caminho sugerido é o da elaboração de uma precisa exegese daquele artigo, cujo verdadeiro sentido ainda não foi idealmente apreendido pela inteligência doutrinária" In TEIXEIRA FILHO, Manoel Antonio. A prova no processo do trabalho. São Paulo: Ltr, 2003, p.124

${ }^{157}$ A propósito da regra do art.818 da CLT interessante a visão de Márcia Azário ao compreendê-lo como uma regra geral típica de um processo com peculiaridades próprias. Nesse sentido: "propositalmente, vale dizer, deixamos de incluir a hipótese de 'inversão' do ônus da prova prevista no art.818 da CLT. Entendemos que não se trata de efetiva 'inversão', mas sim de regra geral de distribuição aplicável no âmbito das relações jurídicotrabalhistas, isto é, com regras próprias para o ramo do processo ao qual se aplica (processo do trabalho, o que se rege por princípios diversos dos que norteiam o processo civil, dentre os quais, por exemplo, o da desigualdade compensatória, da indisponibilidade e da busca da verdade real." AZÁRIO, Márcia Pereira. Dinamização da Distribuição do ônus da prova no processo civil brasileiro. Tese (Mestrado), Faculdade de Direito, Universidade Federal do Rio Grande do Sul, 2006, p.95

${ }^{158}$ Amauri Mascaro do Nascimento ao tratar desse critério do art.818 da CLT afirma que o mesmo nem sempre atende às necessidades do processo trabalhista na medida em que sobrecarrega o empregado que não apresenta as mesmas condições e facilidades probatórias do empregador. In Curso de Direito Processual do Trabalho. São Paulo: Saraiva, 1994, p. 267. Para Wagner Giglio o art.818 da CLT representa uma das mais primitivas formas de 
processo do trabalho enquanto instrumento de implementação efetiva do direito substancial do trabalho.

Registre-se ainda a crítica de Sérgio Pinto Martins quanto ao disposto no art.818 da CLT:

"Se interpretássemos essa regra ao pé da letra, chegaríamos a situações inusitadas. Se o reclamante alegasse que trabalhava em certo horário, seria dele a prova. Se na contestação a empresa alegasse que o horário era outro, seria ela que teria de fazer a prova. Contudo, se o reclamante alegasse outra coisa na réplica, então o ônus da prova retornaria a ele. Assim teríamos um entendimento elástico do que viria a ser ônus da prova com base na regra do art.818 da CLT. No entanto, essa orientação deve ser completada pelo art.333 do CPC (...)" 159

Posicionamento diametralmente oposto é o manifestado classicamente por Manoel Antonio Teixeira Filho. Segundo o autor há colisão frontal entre o art.818 da CLT com o art.333 do CPC, não havendo que se falar em omissão da CLT no particular vez que dispõe de previsão específica e bastante de modo que se em alguma oportunidade venha a revelar-se insuficiente a dicção celetista caberá ao julgador verificar no caso concreto quem está apto à produção da prova confirme os meios e condições de que disponha, sem se conferir importância à quem detenha o interesse na produção de tal prova. ${ }^{160}$ E nessa ordem de ideias o autor não está sozinho pois César Pereira da Silva Machado Junior adere a esse inconformismo igualmente acreditando ser impossível trasladar-se para o processo do trabalho a regra do art.333 do CPC eis que critério estribado no pressuposto da igualdade formal dos litigantes. ${ }^{161}$

distribuição do ônus da prova, sendo notória a inconveniência da disposição celetista, fato que tem levado a adoção da regra do art.333 do CPC pelos interpretes, nada obstante não se reconheça omissão da legislação processual trabalhista no particular. In Direito Processual do Trabalho. São Paulo: Saraiva, 1997, p.189

${ }^{159}$ MARTINS, Sérgio Pinto. Direito processual do trabalho. São Paulo: Atlas, 2000, p.284.

${ }^{160}$ TEIXEIRA FILHO, Manoel Antonio. Curso de Direito Processual do trabalho. Vol.2.São Paulo: LTr, 2009, pp.976-977

${ }_{161}$ MACHADO JUNIOR, César Pereira da Silva. O ônus da prova no processo do trabalho. São Paulo: Ltr, 2001, p.94 


\subsection{Relativização do ônus da prova no processo do trabalho}

Se o próprio processo civil a partir especialmente do advento do Código do Processo do Consumidor vem relativizando ${ }^{162}$ as bases da distribuição do ônus da prova, com maior razão no processo do trabalho não se pode dar o tratamento neutro e individualista do art.333 do CPC.

As respostas insatisfatórias que vinham sendo obtidas a partir da adoção das regras inflexíveis do ônus da prova sob a premissa de uma igualdade apenas formal das partes, no dia a dia da prática processual trabalhista foram ganhando espaço na doutrina e jurisprudência inúmeras exceções à aplicabilidade absoluta do disposto no art.818 da CLT c/c art.333 do CPC. ${ }^{163}$ Essa insurgência ao modelo legal deu-se muito mais em razão da própria falta de adequação às singularidades das situações de direito material do trabalho. De fato, as normas do encargo probatório como postas consideram apenas a posição das partes e a natureza dos fatos e não, repita-se, a particularidade de cada situação concreta subjacente à relação processual estabelecida.

Portanto, conforme bem constatou Edmar Salgado "passando em revista os casos exceptivos, verifica-se que a justificativa da inversão do ônus probatório deita suas raízes o campo do direito material, onde a desigualdade entre as partes da relação empregatícia não somente é reconhecida de longa data, como também funcionou (e talvez ainda funcione) como motor da evolução legislativa trabalhista e razão legitimante da sua própria existência, bastando uma breve visita ao texto da CLT para ali encontrarmos normas rígidas de proteção ao trabalho que foram elaboradas em detrimento da liberdade de negociação entre as partes contratantes e que se baseiam exatamente no pressuposto de sua desigualdade". ${ }^{164}$

\footnotetext{
${ }^{162}$ Renato Saraiva após entender pela aplicabilidade do art.818 da CLT c/c 333 do CPC reconhece que a doutrina e jurisprudência vêm paulatinamente admitindo a inversão do ônus da prova para a empresa com o claro intuito de proteger a parte hipossuficiente da relação jurídica trabalhista. In Curso de Direito Processual do Trabalho. Método, São Paulo, 2007, p.340.

${ }^{163}$ SALGADO, Edmar Souza Salgado. O princípio da efetividade no processo do trabalho. Tese (Mestrado), Faculdade de Direito, Universidade de São Paulo, 2008 p.185
} 
Embora haja maior relativização das bases de distribuição do encargo probatório, existindo inclusive várias súmulas e orientações jurisprudenciais do próprio Tribunal Superior do Trabalho que, ainda que não explicitamente, mas consideram a maior aptidão da prova para atribuição desse ônus. ${ }^{165}$

Decisões outras adequadas a um pensamento mais contemporâneo de alguns juízes do trabalho que com base no Código de Defesa do Consumidor e no conceito de hipossuficiência igualmente exigem da parte mais forte (técnica ou economicamente) que traga ao processo os subsídios probatórios.

Autores trabalhistas a exemplo de Mauro Schiavi aplicam basicamente a regra do art.333 do CPC, acreditando que o art.818 da CLT não é completo, tendo difícil interpretação e aplicabilidade prática. Compreendem o art.818 da CLT como se ambas as partes detivessem o encargo probatório de todos os fatos aventados em suas peças processuais respectivas e acabam por aplicá-lo em conjunto com o art.333 do CPC, que parecer ser o próprio critério adotado pelo Tribunal Superior do Trabalho haja vista o disposto na Súmula no. $6 .{ }^{166}$

\footnotetext{
${ }^{164}$ Idem. Ibidem, p. 186.

${ }^{165}$ Nesse sentido: SUM-6 EQUIPARAÇÃO SALARIAL. ART. 461 DA CLT (...) VIII - É do empregador o ônus da prova do fato impeditivo, modificativo ou extintivo da equiparação salarial. SUM-16 NOTIFICAÇÃO Presume-se recebida a notificação 48 (quarenta e oito) horas depois de sua postagem. O seu não-recebimento ou a entrega após o decurso desse prazo constitui ônus de prova do destinatário. SUM-212 DESPEDIMENTO. ÔNUS DA PROVA.O ônus de provar o término do contrato de trabalho, quando negados a prestação de serviço e o despedimento, é do empregador, pois o princípio da continuidade da relação de emprego constitui presunção favorável ao empregado. SUM-338 JORNADA DE TRABALHO. REGISTRO. ÔNUS DA PROVA .I - É ônus do empregador que conta com mais de 10 (dez) empregados o registro da jornada de trabalho na forma do art. 74, $\S 2^{\circ}$, da CLT. A não-apresentação in-justificada dos controles de frequência gera presunção relativa de veracidade da jornada de trabalho, a qual pode ser elidida por prova em contrário. II - A presunção de veracidade da jornada de trabalho, ainda que prevista em instrumento normativo, pode ser elidida por prova em contrário. OJ-SDI1-301 FGTS. DIFERENÇAS. ÔNUS DA PROVA. LEI No 8.036/90, ART. 17.Definido pelo reclamante o período no qual não houve depósito do FGTS, ou houve em valor inferior, alegada pela reclamada a inexistência de diferença nos recolhimentos de FGTS, atrai para si o ônus da prova, incumbindo-lhe, portanto, apresentar as guias respectivas, a fim de demonstrar o fato extintivo do direito do autor (art. 818 da CLT c/c art. 333, II, do CPC).

${ }^{166}$ SCHIAVI, Mauro. Manual de direito Processual do Trabalho. LTr 2009 pp. 520- 522. Súmula no.6, VIII do C.TST - "É do empregador o ônus da prova do fato impeditivo, modificativo ou extintivo da equiparação salarial.
} 
Mas, ainda assim, é preciso que o juiz do trabalho não se fixe de forma absoluta nas regras do art.333 do CPC, e adote, sem vislumbrar ofensa legal ao próprio art.818 da CLT, as cargas probatórias dinâmicas, interpretação mais consentânea, repita-se, com o direito material envolvido.

Nada obstante, na prática tem-se percebido que de fato o intérprete tem flexibilizado a interpretação do art.818 da CLT e do art.333 do CPC para admitir a inversão do ônus da prova no processo do trabalho com a utilização de vários pressupostos dentre eles o princípio da aptidão da prova, os próprios critérios do Código de Defesa do Consumidor por aplicação subsidiária, pautando-se na hipossuficiência do empregado e na verossimilhança de suas afirmações a fim de determinar que o réu produza alguma prova, dentre outros.

Além do art.818 da CLT uma outra orientação quanto à distribuição do ônus da prova foi adicionada à norma celetista a partir da criação do procedimento sumaríssimo. Trata-se do art. 852-D ao dispor que “o juiz dirigirá o processo com liberdade para determinar as provas a serem produzidas, considerado o ônus probatório de cada litigante, podendo limitar ou excluir aquelas que considerar excessivas, impertinentes ou protelatórias, bem como para apreciá-las e dar especial valor às regras de experiência comum ou técnica". Percebe-se da parte final do artigo em tela a expressa menção às máximas de experiência como critério também para possibilitar a redistribuição do ônus da prova.

Uma ordem de reconhecimento da aplicação da inversão do ônus da prova na verdade tem partido da constatação do estado de hipossuficiência do empregado ou da vulnerabilidade técnica a partir da consideração de que a prova possa se tornar excessivamente onerosa àquele ator processual de modo a inviabilizar a efetividade do próprio direito postulado.

Intérpretes há que aplicam a regra do Código de Defesa do Consumidor em razão do art.769 CLT com os critérios alternativos daquela legislação especial, repetindo-se: hipossuficiência (não necessariamente a econômica, mas também técnica revelada 
especialmente pela dificuldade excessiva de se produzir a prova especialmente pela defasagem de informação) ou verossimilhança da alegação a partir inclusive das máximas de experiência. Um particularismo do processo do trabalho diz respeito inclusive à própria hipossuficiência, no mais das vezes, presumida do trabalhador que geralmente demanda em situação de desemprego.

A saída pela aplicação subsidiária do Código de Defesa do Consumidor por vezes não é tranquila haja vista os opositores a entender que se tratando de legislação especial, na ordem de aplicação subsidiária à CLT não poderia prevalecer sobre as disposições do próprio CPC, cuja regra estática do art.333 portanto teria a preferência legal.

Sob outra perspectiva, mas não afastando a possibilidade de aplicação do Código de Defesa do Consumidor, ${ }^{167}$ o autor Carlos Roberto Reis de Paula estabelece, calcado na doutrina de Márcio Túlio Viana a sistematização da inversão do ônus da prova a partir de três grandes princípios, quais sejam, princípio da aptidão para a prova ${ }^{168}$, princípio in dubio pro operario e princípio da preconstituição da prova. ${ }^{169}$

Após a edição do art.852-D da CLT já houve manifestação da doutrina no sentido de que não haveria mais dúvida sobre o cabimento da inversão do ônus da prova no processo do trabalho, não só em razão da aplicação por analogia do art. $6^{\circ}$. VIII do Código de

${ }^{167}$ Reis de Paula é claro ao abordar as possibilidades do CDC como uma consagração legal do critério de inversão do ônus da prova apto a ser invocação em subsidiariedade pelo juiz do trabalho. Ob.cit. p.151

${ }^{168}$ Relativamente à aptidão para a prova e a propósito da desigualdade das partes na relação trabalhista também Paulo Eduardo de Oliveira os reconhece como critérios para inversão do ônus da prova, ao tratar da prova do dano pessoal no processo do trabalho. Aponta o autor a disparidade dos agentes contrapostos na relação de emprego - de um lado o empregador com poderio econômico e de outro o empregado, com necessidade de trabalhar para cuidar do sustento próprio e familiar. E, especialmente em relação à jurisprudência do Tribunal Superior do Trabalho indica que aquela vem adotando posição restritiva na concessão de danos pessoais, nada obstante em diversas situações o dano pessoal implique na necessidade da inversão do ônus da prova pela aplicação do princípio da capacidade para produção da prova. Para o autor a ocorrência do dano pessoal não precisa necessariamente ser provada, podendo, em algumas circunstâncias, ser presumida, como no caso de rescisão do contrato imotivadamente e sem pagamento das verbas rescisórias., de forma que a responsabilidade do empregador no caso seria objetiva quanto à ocorrência do dano pessoal.Discriminação - TST - prova do empregado. In O Mundo do Trabalho, Volume I Leituras Críticas da Jurisprudência do TST: em Defesa do Direito do Trabalho. Coordenadores, COUTINHO, Grijalbo Fernandes; MELO FILHO, Hugo Cavalcanti; SOUTO MAIOR, Jorge Luiz; FAVA, Marcos Neves. LTR, 2009.

${ }^{169}$ Ob.cit. p.59 
Defesa do Consumidor, mas agora pela disposição explícita naquele primeiro. Nem se alegue que a disposição é específica ao procedimento sumaríssimo posto que em matéria probatória não seria o procedimento que limitaria os podres do juiz na direção do processo na busca da verdade real. $^{170}$

A propósito da situação da aptidão para prova preciso o ensinamento de Porras López que assim se expressa: “a) La carga de la prueba es una obligación, un derecho y un deber, en la ciencia procesal moderna; b) Debe probar, el que esta en aptitud de hacerlo, independientemente de que sea el actor o el demandado; c) Para la distribución de la prueba debe atenderse no tanto a la situación de los contendiente, sino a la finalidad del proceso, ya que quien ofrezca mejores pruebas, obtendrá una sentencia favorable; d) las pruebas se dirigen al juez, a fin de que este resuelva los juicios secundum allegata et probata" 171

A princípio, pois, incumbido da prova será aquele que tem melhores condições para sua confecção ${ }^{172}$, o que será desenvolvido no último capítulo como pressuposto da dinamização do encargo probatório, juntamente com os critérios da preconstituição da prova (a parte que tem o dever de manter a documentação do contrato de trabalho deve apresentá-la em juízo) e da aplicação do princípio protetor do direito do trabalho na sua vertente do in dubio pro misero.

Outros questionamentos que se realizam em matéria de inversão do ônus da prova dizem respeito à sua consideração pelos autores trabalhistas sob a vertente de regra de julgamento ou regra de procedimento o que automaticamente gera reflexos na compreensão do momento processual em que ocorrerá essa alteração da distribuição do encargo probatório.

\footnotetext{
${ }^{170}$ LEITE, Carlos Henrique Bezerra, 1960-; MACHADO, Meireely Alvarenga. A nova portaria do MTE sobre registro eletrônico de ponto e a questão da inversão do ônus da prova. Revista IOB Trabalhista e Previdenciária. São Paulo, a. 21, n. 247, jan. 2010. p.9

${ }^{171}$ PORRAS LOPEZ apud TEIXEIRA FILHO, Manoel Antonio. Curso de Direito Processual do trabalho. Vol.2 São Paulo: LTr, 2009, p.971

${ }^{172}$ Manoel Antonio Teixeira Filho afirma que o princípio da aptidão da prova deve ser eleito como principal elemento supletivo do processo do trabalho em matéria de ônus da prova de forma a afastar de forma definitiva a
} 
A visão clássica também na perspectiva processual trabalhista tem prevalecido e de uma maneira geral tem sido considerado o ônus da prova como regra de julgamento ${ }^{173}$ de modo que se a parte descumpri-lo olvidando-se de produzir as provas que lhe cabem, conforme as regras de distribuição, o juiz proferirá de qualquer forma uma decisão não lhe sendo lícito permanecer em estado de dúvida. Logo a parte que deveria ter produzido a prova e não o fez, arcará com responsabilidade pela sua inércia (que não necessariamente importará em prejuízo, ante o princípio da aquisição processual das provas.

Emília Simeão Sako igualmente propugna pela classificação do ônus da prova como regra de juízo ao afirmar que

"a declaração de inversão do onus probandi não precisa, necessariamente, ser expressa, pois na sentença, quando o juiz analisar as demais provas, irá dizer quem tinha o ônus de produzir a prova e não produziu, independentemente de ter emitido declaração anterior sobre a quem competia esse ônus. O art. $6^{\circ}$, VIII, do CPC não exige expresso pronunciamento sobre quem compete prova. é suficiente, para legitimidade da decisão que o juiz no julgamento da causa, diga em que prova se baseou para proferir a decisão. Nenhuma nulidade haverá caso o juiz não declare invertido o ônus da prova, pois o ônus da prova é um dever da parte. Além disso, nem o CDC, nem outro diploma legal obrigam o juiz a declarar de forma expressa

presença incômoda do art.333 do CPC. In. Curso de Direito Processual do trabalho. Vol.2.São Paulo: LTr, 2009, p. 977

${ }^{173}$ Gian Antonio Micheli após tratar do ônus da prova como regra de julgamento não demonstrou dúvidas de que também no processo individual do trabalho competiria às partes poderes relevantes quanto à produção de provas representando seus atos o exercício de um poder, ou em outras palavras, "o princípio inquisitório não transforma as partes em meros objetos do processo, tanto que se fala não só em ônus da demanda senão também em ônus da afirmação." MICHELI, Gian Antonio. La carga de la prueba. Buenos Aires: Ediciones juridicas EuropaAmerica, 1961, p.256. Michele também faz referência a opiniões contrárias que entendem não existir no processo do trabalho um problema de ônus da prova propondo entretanto um questionamento relativo a "como" o juiz do trabalho deverá julgar quando não tenha chegado a formar sua convicção sobre as produzidas pelas partes ou ainda determinadas de ofício. Noticia que para Jaeger o juiz estaria livre dos vínculos constituídos pelo art.1312 (Código (Civil Italiano de 1865)). Para Michele "o que parece certo é que o juiz deve, como quer que seja, julgar, de maneira que a regra de julgamento antes estudada, exista também no processo individual do trabalho. Na verdade, se ao juiz do trabalho não se lhe podem negar amplos poderes instrutórios de investigação (...) e uma grande liberdade na valoração das provas, não se diz que o critério constante no art.54 seja inaplicável porque o mesmo, ainda que representando um principio geral do processo civil não está absolutamente em contraste com a estrutura do processo individual do trabalho que o legislador italiano mostra tratar como um processo normal. Continua o autor noticiando que no processo coletivo do trabalho o juiz tem um amplo poder instrutório vez que também mais intenso o interesse geral controvertido. Para o autor, o juiz do trabalho mesmo quando julga controvérsias coletivas não se transforma, conservando sua estrutura de um juiz civil normal, mas assinala que nestes casos julga com um juízo de equidade...In. op. cit. pp.257-258 
invertido o ônus da prova antes do julgamento e nem mesmo no julgamento. As partes tem o conhecimento da lei, não podendo alegar o seu desconhecimento. Além disso, devem pautar-se conforme o princípio da boa-fé, o qual impõe o dever de agir com lealdade, afirmando e sustentando apenas a verdade" 174

A autora tem posição mais radical ao referir ainda que não há sequer necessidade de que o juiz na sentença explicite se inverteu ou não o ônus, vislumbrando-se neste caso negativa de prestação jurisdicional. ${ }^{175}$

Entretanto, as regras do ônus da prova não podem se limitar a tal característica na medida em que, como visto, são regras de conduta que servem para orientar a atividade processual das partes, apontando para uma necessária diligência a fím de evitar prejuízos ao acolhimento de suas pretensões de direito material. Desta forma não há como rechaçar a importância das regras do ônus da prova durante a fase instrutória. Com efeito, a parte que não observe o funcionamento da distribuição do ônus da prova assume o risco da derrota.

Dando ênfase também ao ônus da prova como regra de procedimento inclusive para fixar o momento para uma adequada inversão do encargo da prova assim leciona Guilherme Guimarães Feliciano:

"Ao contrário do que entende a doutrina processual recorrente, pensamos que o problema da inversão do ônus da prova não é apenas um problema de juízo (= julgamento), mas também de procedimento. Isto é especialmente verdadeiro nos processo de garantia de direitos humanos fundamentais, nos quais frequentemente se dão hipótese de direitos indisponíveis "ab ovo", que não se sujeitam sequer à confissão ficta (art.351 do CPC). Sob tais circunstâncias, cabendo ao réu produzir as provas da não violação, é medida de inteira plausibilidade que, a bem do devido processo legal e da prevenção das "decisões-surpresa", o magistrado esclareça a situação durante o processo e determine a inversão da ordem de instrução."176

\footnotetext{
${ }^{174}$ SAKO, Emília Simeão Albino. A prova no processo do trabalho: os meios de prova e o ônus da prova nas relações de emprego e trabalho. São Paulo: LTr, 2008, p.31

175 Relembre-se a lição de Fredie Didier: "Reservar a inversão do ônus da prova ao momento da sentença representa uma ruptura com o sistema do devido processo legal, ofendendo a garantia do contraditório. Não se pode apenar a parte que não provou a veracidade ou inveracidade de uma determinada alegação sem que se tenha conferido a ela a oportunidade de fazê-lo (lembre-se que o ônus subjetivo acaba por condicionar a atuação processual da parte)." 175 DIDIER JR, Fredie; BRAGA, Paula Sarno; OLIVEIRA, Rafael. Curso de Direito Processual Civil vol.2. Salvador: Juspodivm, 2009, p.85

176 FELICIANO, Guilherme Guimarães. Tutela processual dos direitos humanos nas relações de trabalho. Disponível em http://jus2.uol.com.br/doutrina/texto.asp?id=7810. Acesso em 7/11/2006.
} 
Nesse sentido também Edilton Meirelles ${ }^{177}$ :

"Em verdade, o disposto no art.6 $6^{\circ}$., inciso VIII, do CPC, não estabelece uma simples regra de julgamento, mas sim um comando que prevê um procedimento a ser adotado pelo juiz, vinculado às atividades a serem desenvolvidas pelas partes, especialmente pelo réu-fornecedor, ao se impor a este um ônus processual que ordinariamente não lhe seria exigível. A partir dessa decisão, o juiz estaria autorizado, para compatibilizá-la à atividade procedimental, a inverter os demais encargos processuais, como por exemplo, em relação ao ônus pecuniário da realização da perícia quando determinada de ofício (...).”

Em apertada síntese, aos adeptos da conceituação do ônus da prova como regra de julgamento o momento da inversão do ônus se dará somente na sentença e para aqueles que vêem a regra como de procedimento, será, por óbvio explicitada às partes em momento anterior ao início da instrução. 


\section{CAPÍTULO III - TEORIA DA DISTRIBUIÇÃO DINÂMICA DO ÔNUS} DA PROVA

\section{Considerações gerais}

O dia a dia dos Tribunais reflete cada vez mais o grau da complexidade da sociedade contemporânea e sendo o próprio processo um fenômeno cultural ${ }^{178}$, nele tem-se revelado a insuficiência das regras clássicas ou também denominadas regras estáticas aplicáveis à distribuição do ônus da prova abrindo oportunidades para que nesse âmbito também comecem a concorrer as chamadas regras dinâmicas.

Em que pese a visibilidade contemporânea dessas questões, as dificuldades inerentes às técnicas do ônus da prova já se faziam sentir desde há muito. Eduardo J. Couture ao tratar do ônus da prova assim se manifestava em meados do século passado:

"Este é, fora de qualquer dúvida, o problema mais complexo e delicado de toda esta matéria. A doutrina vem se debatendo há séculos frente a tais dificuldades, que afetam não somente os princípios teóricos, senão também a própria política da prova.

Nos esforços legislativos dos últimos anos observa-se claramente uma evolução. Aceitando a opinião dos autores de fins do século passado e começos do atual, no sentido de considerar o problema do ônus a prova como pertencente uma fase do direito já definitivamente superada, vem-se abandonando a solução que ainda é consagrada nos códigos hispano-americanos, e que consiste em repartir de antemão a atividade probatória entre as partes, procurando-se, ao contrário, aproximar o juiz civil do penal, confiando-lhe uma iniciativa considerável em ateria probatória. (...) Neste sentido é necessário acompanhar a mesma orientação do processo penal em que se preferiu "riscar a expressão 'ônus da prova' do vocabulário da ciência." 179

\footnotetext{
${ }^{177}$ MEIRELES, Edilton. Inversão do ônus da prova no processo trabalhista. GENESIS - Revista de Direito do Trabalho. Curitiba, n. 51, p. 317, mar. 1997

178 Compreendendo o processo como fenômeno cultural Carlos Alberto Álvaro de Oliveira (Do formalismo no processo civil. São Paulo: Saraiva, 2010, p.31) e ainda Artur Thompsen Carpes (Prova e Participação no Processo Civil: Dinamização dos ônus probatórios na perspectiva dos direitos fundamentais. Tese (Mestrado), Faculdade de Direito, Universidade Federal do Rio Grande do Sul, 2008, pp.13-16).

${ }^{179}$ COUTURE, Eduardo Juan. Fundamentos do Direito Processual Civil. (trad. Rubens Gomes de Sousa). São Paulo: Saraiva, 1946. pp. 160-161
} 
Transposto outro século, os problemas processuais em torno do encargo probatório continuam em evidência, sendo certo que após mudanças nas perspectivas do que eram e hoje são os escopos do próprio processo, com primazia atualmente para as finalidades de pacificação social e realização efetiva da justiça, têm surgido os defensores dessa nova perspectiva de atribuição do ônus da prova.

Evoluíram as teorias, evoluiu o Direito. Após a primazia de teorias calcadas em posturas de cunho liberal no modo de ver o processo, o processualista Augusto Mario Morello veio a defender uma visão solidarista do ônus da prova, partindo da aplicação dos princípios de solidariedade, cooperação e boa-fé que se sobrepõem à regra clássica observando as particularidades do caso concreto, propondo, em última instância uma postura diferencial do juiz e das próprias partes possibilitando uma flexibilização das normas tradicionais da carga probatória quando uma das partes não observe o dever de colaboração. 180

Importante a teoria de Morello que, se não eliminou a regra estática do ônus da prova apontou já para um caminho novo de flexibilização das regras e que redundaria num abrir de portar às formulações de outro jurista argentino (Peyrano) que despontaria com a teoria a ele atribuição das "Cargas Probatórias Dinâmicas".

Em apertada síntese registre-se que a Teoria da Carga Probatória Dinâmica, ou ainda Teoria Dinâmica de Distribuição do ônus da prova já é bastante utilizada na Argentina, Espanha e Uruguai, em especial para as questões de responsabilidade profissional dos médicos, tendo como precursor o jurista argentino Jorge W. Peyrano para quem "em tren de identificar la categoria de las 'cargas probatorias dinamicas', hemos visualizado - entre otras - como formando parte de la misma a aquélla según la cual se incumbe la carga probatoria a quein - por las circunstancias del caso y sin que interese que se desempeñe como actora o demandada - se encuentre en mejores condiciones para producir la probanza

180 MORELLO, Augusto Mario. La prueba: tendencias modernas. Buenos Aires: Abeledo-Perrot, 1991, pp.5962 
respectiva" ${ }^{181}$, ou seja, incumbido da prova é aquele detenha melhores condições para tanto conforme as circunstâncias do caso concreto.

A par de toda referência aos doutrinadores argentinos a quem se reputa antecedência na percepção da teoria da distribuição dinâmica do ônus da prova, há quem questione esse dado. Maximiliano García Grande afirma expressamente que essa teoria não é moderna e tampouco argentina, noticiando que a manifestação mais antiga das bases das cargas probatórias dinâmicas se deve a Jeremias Bentam em 1823 que ao se aperceber de abusos e dilações causadas no processo propôs a imputação da carga àquele que detivesse melhores condições de provar. ${ }^{182}$

Percebe-se de pronto que a teoria da carga probatória dinâmica rompe com as regras rígidas e estáticas da distribuição do onus probandi tornando-as mais flexíveis e dinâmicas, adaptáveis a cada caso, não importando a posição das partes e tampouco a qualificação do fato como constitutivo, impeditivo, modificativo, ou extintivo. Vale dizer, é dinâmica porque o encargo de provar é independente de enfoques apriorísticos, limitando-se a indicar que o peso da carga da prova recai sobre aquele em melhores condições técnicas ou profissionais de produzi-la. ${ }^{183}$

O toque fundamental da teoria da carga dinâmica probatória é a valoração pelo juiz a respeito de qual das partes dispõe das melhores condições de suportar o ônus da prova naquele específico caso concreto a fim de lhe impor tal ônus, ainda que os fatos objeto de prova tenham sido alegados pela parte contrária.

181 PEYRANO, Jorge W. Aspectos procesales dela responsabilidade profesional. Las responsabilidades profesionales - Libro Homenaje ao Dr. Luis O. Andorno.Coord.Augusto M. Morello e outros. La Plata: LEP, 1992, p.263, apud DALL'AGNOL JUNIOR, Antonio Janyr. Distribuição Dinâmica dos Ônus Probatórios. Revista Jurídica, 137. Porto Alegre, no. 280, 2001, p.97

182 GARCÍA GRANDE, Maximiliano. Cargas Probatórias Dinâmicas: Ni nuevas, ni argentinas, ni aplicables. Disponível em www.e-derecho.org.ar/congresoprocesal/cargas\%20DinE1micas\%20grande_.pdf, pg.01-02

${ }^{183}$ AIRASCA, Ivana María. "Reflexiones sobre la doctrina de las Cargas Probatorias Dinámicas. In.: PEYRANO, Jorge W.(dir.); LÉPORI WHITE, Inês (coord.). Cargas probatorias dinámicas. Buenos Aires: Rubinzal-Culzoni, 2004, p.136 
Antonio Janyr Dall'Agnol Junior em artigo específico referente a esse assunto nos traz as premissas dessa Teoria: “a) inaceitável o estabelecimento prévio e abstrato do encargo; b) ignorável é a posição da parte no processo; e c) desconsiderável se exibe a distinção já tradicional entre fatos constitutivos, extintivos, etc. Releva, isto sim: a) a caso em sua concretude e b) a 'natureza' do fato a provar - imputando-se o encargo àquela das partes que, pelas circunstâncias reais, se encontra em melhor condição de fazế-lo. ${ }^{184, "}$ (g.n)

Roland Arazi outro renomado doutrinador da Teoria da Prova, corroborando a idéia acima, ensina que:

\begin{abstract}
"Es importante que el juez valore las circunstancias particulares de cada caso, apreciando quién se encontraba en mejores condiciones para acreditar el hecho controvertido, así como las razones por las cuales quien tenía la carga de probar no produjo la prueba. Este criterio es aplicado con frecuencia por la jurisprudencia y tiene el aval de la CSJN que recientemente ratifico su postura diciendo que las reglas atinentes a la carga de la prueba deben ser apreciadas en función de la índole y características del asunto sometido a la decisión del órgano jurisdiccional, principio este que se encuentra en relación con la necesidad de dar primacía - por sobre la interpretación de la norma procesale -a la verdad jurídica objetiva, de modo que su esclarecimiento no se vea perturbado por un excesivo rigor foral. (...l) A esta concepción se la ha denominado dinámica, por su movilidad para adaptarse a los casos particulares, a fin de oponerla a una idea estática igual para todos los supuestos sin atender a las circunstancias especiales. Ella ha tenido un nuevo brillo por los importantes trabajos de prestigiosos juristas que han pregonado en favor de una idea de solidaridad y colaboración de las partes en la etapa probatoria del proceso, sin sujetarse a reglas rígidas que hagan recaer todo el esos una en otra" 185
\end{abstract}

Outros juristas argentinos também nos informam que parte da doutrina daquele país tem aceitado o caráter científico da teoria das cargas probatórias dinâmicas. ${ }^{186}$

Na seara nacional Miguel Kfouri Neto faz uma didática síntese da vivacidade dessa teoria ora em foco ao asseverar que "as regras que determinam a posição da parte litigante - autor ou réu - nos processos, quanto à prova, em geral são imutáveis, ao longo

\footnotetext{
${ }^{184}$ DALL'AGNOL JUNIOR, Antonio Janyr. Distribuição Dinâmica dos Ônus Probatórios. Revista Jurídica, 137. Porto Alegre, no.280, 2001

${ }^{185}$ ARAZI, Roland. La prueba en el proceso civil. 2a edição. Buenos Aires: Ediciones La Rocca, 1998
} 
da demanda. No entanto, por decisão do juiz, tais posições podem variar - e o sistema deixa de ser pétreo, para se tornar dinâmico". ${ }^{187}$

Conferida, portanto, ao juiz maior discricionariedade na avaliação da distribuição das regras do ônus da prova vez que ao apreciar o caso concreto que lhe é posto perceber que, nos termos estritamente legalistas (art.333, incisos I e II do Código de Processo Civil), o ônus da prova recai sobre a parte em condições materiais menos vantajosas, aquele deverá modificar a distribuição do ônus da prova em prol da parte técnica ou economicamente hipossuficiente. Essa é a direção apontada, inclusive, por projetos de lei em andamento no País como se verá ao final do capítulo.

De outro lado há que se pontuar a diferenciação entre a técnica da distribuição dinâmica e a da inversão do ônus da prova, registrando-se que aquela é mais abrangente na medida em que, a princípio só se pode falar em inversão a partir do estabelecimento prévio e abstrato deste encargo. Já na distribuição dinâmica será o magistrado a partir de cada caso concreto que determinará o que e a quem incumbe provar com base nas especialmente nas máximas de experiência. ${ }^{188}$ Aponte-se, também que a inversão do ônus da prova depende do preenchimento de requisitos legais ( $v g$. verossimilhança das alegações, hipossuficiência) ou deriva ainda do estabelecimento de presunções.

Há na teoria dinâmica, em síntese, verdadeiro rompimento da visão estática tradicional da distribuição do ônus da prova entre as partes a fim de adequar a atribuição ao caso concreto, partindo do abandono do estabelecimento do prévio e abstrato do ônus probatório e conferindo-se pouca importância à natureza do fato invocado (constitutivo, extintivo, modificativo ou impeditivo do direito) e transferindo a perspectiva de análise às peculiaridades do caso concreto.

\footnotetext{
${ }^{186}$ LÓPEZ-MIRÓ, Horacio G; CALANDRI, Laura Cristina [et al.]. Probar o sucumbir: los tres grados del convencimiento judicial y la regla procesal del onus probandi. Buenos Aires : Abeledo-Perrot, 1998, p.38

187 KFOURI NETO, Miguel. Culpa médica e ônus da prova: presunções, perda de uma chance, cargas probatórias dinâmicas, inversão do ônus probatório e consentimento informado: responsabilidade civil em pediatria, responsabilidade civil em gineco-obstetrícia. São Paulo: Revista dos Tribunais, 2002, p.123
} 
A distribuição estática do ônus da prova sob o prisma da posição da parte em juízo e da natureza do fato estaria na verdade mais preocupada com a decisão judicial do que com a própria tutela do direito lesado ou ameaçado não considerando quaisquer aspectos que digam respeito à dificuldade ou impossibilidade da parte demonstrar seus fatos em juízo $^{189}$, que ao fim e ao cabo podem inibir a própria tutela judicial desses mesmos direitos em verdadeiro desrespeito à ordem constitucional especialmente no que tange ao cumprimento do primado relativo à tutela jurisdicional efetiva.

Chiovenda após ponderar que a o ônus da prova relaciona-se intimamente com o princípio dispositivo, também acaba por admitir que atualmente haja uma tendência contrária a esse mesmo princípio especialmente no que se refere à distribuição do ônus da prova e nesse sentido, invoca Kohler (Civilprozessrecht, $\$ 55)$, autor que "reputa toda a doutrina sobre o ônus da prova como própria de um período 'já sobrepassado', como uma derivação do sistema da prova legal. Ele sustenta que às considerações de equidade aproximativa, que inspiram as normas gerais sobre o ônus da prova, devem substituir-se considerações precisas de equidade, no caso dado, por obra do juiz. O juiz já tem nas mãos, no próprio julgamento supletório, um instrumento para dar preponderância à equidade no caso concreto" 190

É esse mesmo autor italiano que indica que o próprio código suíço se inspira nesse princípio da liberdade do juiz e invocando Huber (Exposé dês motifs,p.24) afirma que se o juiz tivesse que se ater a uma quota de provas regular e completa, ele seria obrigado a decidir muitas vezes contra toda a equidade e se o julgamento não se expressa segundo as normas provenientes repartição do ônus da prova, mas conforme provavelmente a

\footnotetext{
${ }^{188}$ CAMBI, Eduardo Augusto Salomão. A prova civil: admissibilidade e relevância. São Paulo: Revista dos Tribunais, 2006, p.341

${ }^{189}$ Idem. pp.340-341

${ }^{190}$ CHIOVENDA, Giuseppe. Instituições de Direito Processual Civil. [trad.] Paolo Capitanio. São Paulo: Quórum, 2009, p.945.
} 
verdade, semelhante método não terá nada de arbitrário; ele corresponderá, pelo contrário, ao ideal de um direito mais perfeito. ${ }^{191}$

Essa tendência contemporânea como se verá nos itens seguintes firmou-se sobremaneira na Argentina e Uruguai e por terras nacionais caminha seus primeiros passos na doutrina e na legislação, andando a passos mais largos na jurisprudência, sobretudo proveniente dos Estados do Sul do País.

Na pesquisa realizada até o presente momento percebeu-se que o tema tem encontrado reconhecimento substancial, destacando-se, entretanto, os seguintes autores nas abordagens favoráveis à adoção da doutrina das cargas probatórias dinâmicas, a saber: Antonio Janyr Dall’Agnol Junior (Distribuição dinâmica do ônus probatória), Eduardo Cambi (A Prova Civil. Admissibilidade e Relevância), Wilson Alves de Souza (Ônus da prova considerações sobre a doutrina das cargas probatórias dinâmicas), Robson Renaut Godinho (A distribuição do ônus da prova na perspectiva dos direitos fundamentais), Danilo Knijnik ( As 'perigosíssimas' doutrinas do 'ônus dinâmico da prova'), Fredie Didier Jr, Paula Sarno Braga e Rafael Oliveira ( Curso de Direito Processual Civil, v.2), Marcelo Abelha Rodrigues ( A distribuição do ônus da prova no Anteprojeto do Código Brasileiro de Processos Coletivos), Artur Thompsen Carpes ( Prova e Participação no Processo Civil: Dinamização dos ônus probatórios na perspectiva dos direitos fundamentais), Márcia Pereira Azário (Dinamização da Distribuição do ônus da prova no processo civil brasileiro), Guilherme Guimarães Feliciano (Distribuição Dinâmica do ônus da prova no processo do trabalho - critérios e casuística), dentre outros.

Na própria doutrina nacional Marcelo Abelha Rodrigues entende a carga probatória dinâmica como uma técnica processual capaz de solucionar o problema da

\footnotetext{
${ }^{191}$ Ibidem, p.946, no original 'Cf. Huber, Exposé des motifs. P.24: "Si le juge devait s'en tenir à un appport de preuves régulier et complet, Il serait obligé de décider souvent contre toute éqüite. Et si le jugement n'est pas rendu selon les normes découlant de la répartion du fardeau de la preuve, mais d'après probablement la verité, une semblable méthode n'aura rien d'arbitraire; elle correspondra au contraire à l'idéal d'un droit plus parfait".
} 
distribuição do ônus da prova quando se antevejam situações concretas de desigualdade técnica e econômica. Afirma propriamente o autor que

"uma terceira solução a ser adotada para sanar o problema da injusta distribuição do encargo probatório, além das que já foram comentadas, é a adoção de um sistema flutuante ou dinâmico de distribuição de encargos probatórios, de forma que caberia ao juiz, em cada caso concreto, verificar a quem cabe provar o que, segundo as peculiaridades e facilidade (técnicas e econômicas) para se produzir a prova. Trata-se do que hodiernamente tem sido denominado "carga dinâmica da prova" e a principal vantagem é ao ter um critério legal predefinido da distribuição do encargo probatório, permitindo que o juiz, sensível às circunstâncias da causa, atribuía à parte como maiores possibilidades (técnicas e econômicas) o ônus de provar os fatos controvertidos ". 192

Considerando a teoria dinâmica do ônus da prova como a concepção mais acertada para o tema, Fredie Didier a sintetiza na seguinte expressão "prova quem pode". O doutrinador civilista justifica também seu posicionamento com fundamento nos princípios da adaptabilidade do procedimento ao caso concreto, cooperação e igualdade. ${ }^{193}$

Importante ressaltar que mesmo na Argentina a teoria da carga probatória dinâmica é considerada doutrina de exceção, ou seja, não se trata de nova regra rígida concomitante com a já existente, mas a intenção é formular o que Jorge Peyrano denomina pauta excepcional que funcionará onde as antigas regras funcionam mal ${ }^{194}$.

Na doutrina nacional também Alexandre Câmara e Danilo Knijnik registram preocupação com a recepção da teoria como um sistema excepcional, não podendo vulgarizar-se para simplesmente compensar a inatividade processual ou inércia da parte. ${ }^{195}$

${ }^{192}$ RODRIGUES, Marcelo Abelha. A distribuição do ônus da prova no Anteprojeto do Código Brasileiro de Processos Coletivos. In: GRINOVER, Ada Pellegrini Grinover; MENDES, Aluisio Gonçalves de Castro; WATANABE, Kazuo (coords.). Direito Processual Coletivo e o Anteprojeto de Código Brasileiro de Processos Coletivos. São Paulo: Revista dos Tribunais, 2007, p.249

${ }^{193}$ DIDIER JR, Fredie; BRAGA, Paula Sarno; OLIVEIRA, Rafael. Curso de Direito Processual Civil vol.2. Salvador: Juspodivm, 2009, p.93

${ }^{194}$ PEYRANO, Jorge W. Nuevos lineamientos de las cargas probatórias dinámicas.In.: PEYRANO, Jorge W.(dir.); LÉPORI WHITE, Inês (coord.). Cargas probatorias dinámicas. Buenos Aires: Rubinzal-Culzoni, 2004, p.24. Na mesma linha, BARBERIO, Sérgio José. Cargas Probatórias Dinámicas? Qué deve probar el que no puede probar? In: Cargas probatorias dinámicas. Buenos Aires: Rubinzal-Culzoni, 2004, p.100

195 CÂMARA, Alexandre Freitas. Doenças Preexistentes e ônus da prova: o Problema da Prova Diabólica e uma possível solução". Revista Dialética de Direito Processual. São Paulo: Dialética, 2005, n.31, p.14-15; KNIJNIK, 
Por fim e relativamente à denominação da teoria na própria Argentina tem recebido várias denominações tais como: carga dinâmica de la prueba, carga de prueba compartida, cargas probatórias dinâmicas, doctrina de la prueba compartida, prueba compartida ${ }^{196}$. Igualmente no Brasil a diversidade de opções se apresenta com as seguintes expressões: Teoria da distribuição dinâmica do ônus da prova (Fredie Didier e Artur Thompsem Carpes), Teoria Dinâmica do ônus da prova (Alexandre Câmara e Robson Renaut Godinho), Teoria das Cargas Processuais Dinâmicas (Antonio Janyr Dall'Agnol Junior), Carga probatória dinâmica (Ludmila Marcato, Flávia Pereira Hill, Flávia Zanferdini, Alexandre Gir Gomes, Antonio Danilo Moura de Azevedo, Eduardo Cambi), e não esgotando, por óbvio a questão, Teoria do ônus dinâmico da Prova (Sérgio Knijnik)

Registre-se que neste trabalho optei pela denominação Teoria da Distribuição Dinâmica do ônus da prova justamente pelo contraste em relação à teoria estática e porque mais se aproxima da utilização no direito processual nacional, inclusive do direito processual trabalhista da expressão ônus da prova, sendo certo que a expressão "carga probatória" é inerente aos países de tradição hispânica, que não é o caso do Brasil.

\section{Fundamentos}

A teoria da distribuição dinâmica do ônus da prova ainda não se encontra expressamente positivada no nosso sistema legal vigente havendo que se perquirir, portanto quais os fundamentos que autorizam seu reconhecimento.

Uma primeira ordem de fundamentação a invocar diz respeito à necessidade de aproximação à finalidade do processo como instrumento de realização da justiça. A

Danilo. As (perigosíssimas) doutrinas do 'ônus dinâmico da prova' e da 'situação do senso comum' como instrumentos para assegurar o acesso à justiça e superar a probatio diabólica. Processo e Constituição: Estudos em Homenagem ao Professor José Carlos Barbosa Moreira. São Paulo: RT,2006, p.946

${ }^{196}$ LÉPORI WHITE, Inês. Cargas Probatórias Dinámicas.In.: PEYRANO, Jorge W.(dir.); LÉPORI WHITE, Inês (coord.). Cargas probatorias dinámicas. Buenos Aires: Rubinzal-Culzoni, 2004, p.69 
aplicação de teoria dinâmica tende à realização da justiça vez que considera as particularidades do caso concreto ${ }^{197}$ e o necessário aspecto da igualdade material das partes.

É a partir dessa ordem de ideias que há de se compreender a distribuição dinâmica do ônus da prova como questão constitucional de acesso à justiça porquanto é inerente ao direito de ação a oportunidade das partes influírem na formação da convicção do juiz, dentre outras maneiras por meio de um verdadeiro direito à prova ${ }^{198}$ e sua distribuição equitativa.

Esse aspecto constitucional do ônus da prova não passou despercebido para constitucionalista português Canotilho que ao tratar especificamente do Direito Constitucional do ônus da prova leciona que "se o direito constitucional à prova ao tem sido objecto de desenvolvimento aprofundado, não é de admirar que o problema do ónus da prova seja também remetido para a ciência jusprocessualista (civil, penal e administrativa). A remissão sistemática do regime jurídico do ônus da prova para o direito processual legalmente estabelecido pode, porém, suscitar sérias interrogações em domínios tão sensíveis num Estado de Direito democrático-constitucional como é o do regime de direitos, liberdades e garantias." 199

Na doutrina pátria a fundamentação para o reconhecimento da teoria das cargas probatórias dinâmicas, inclusive de cunho principiológico muito mais apropriado e adequado à concepção de um direito processual constitucional, nos é fornecida pela criteriosa doutrina de Fredie Didier Jr, Paula Braga e Rafael Oliveira, autores para os quais a adoção da teoria em análise revela-se em decorrência de vários princípios, dentre os quais e tendo em

\footnotetext{
${ }^{197}$ CÁRDENAS, Hector H. "Las Cargas Procesales Dinámicas en la ineficácia concursal. In.: PEYRANO, Jorge W.(dir.); LÉPORI WHITE, Inês (coord.). Cargas probatorias dinámicas. Buenos Aires: Rubinzal-Culzoni, 2004, p.409

198 GODINHO, Robson Renault. A distribuição do ônus da prova na perspectiva dos direitos fundamentais. Revista da EMERJ. Rio de Janeiro, v. 10, n. 38, p. 263-84, abr./jun. 2007, p.272

${ }^{199}$ CANOTILHO, Jose Joaquim Gomes. "O ónus da prova na jurisdição das liberdades". Estudos sobre Direitos Fundamentais. 1'a Edição brasileira. São Paulo: RT, 2009, p.170-171
} 
vista a garantia da obtenção de tutela jurisdicional justa e efetiva, o princípio do acesso à justiça expresso no art. $5^{\circ}$., XXXV da Constituição Federal. ${ }^{200}$

A importância desse princípio do acesso à justiça, já consagrado pela Lei Maior levou Danilo Knijnik à conclusão no sentido de que "a violação ao direito à prova pode implicar, de um lado, a inutilidade da ação judiciária, caracterizando assim, violação oculta à garantia de acesso útil à justiça". ${ }^{201}$

Esse mesmo autor é quem melhor sistematiza a questão dos alicerces da teoria dinâmica do ônus da prova, apontando duas ordens de fundamentação, sendo a primeira delas calcada no princípio da igualdade das partes em bases materiais e a segunda calcada nos deveres de lealdade e colaboração das partes. ${ }^{202}$

Relativamente à igualdade material imprescindível a lição de Inês Lépori White quando, ao analisar os antecedentes e fundamentos da teoria da carga probatória dinâmica percebeu que "a doutrina se ocupou tanto em resguardar e proteger a bem denominada liberdade, em todas as suas formas e expressões, que se esqueceu que muitas vezes este ideal não se alcança quando as partes que são beneficiadas por ele não se encontram em igualdade de condições. Esqueceu-se que o livre, lógico, razoável e inclusive justo pode não ser equitativo. E esqueceu-se de acompanhar as mudanças pelas quais passou o direito substantivo nos últimos cem anos". 203

E são justamente aqueles deveres de lealdade e cooperação das partes no processo que representam a segunda ordem de fundamentação a que faz menção Danilo

\footnotetext{
${ }^{200}$ DIDIER JR, Fredie; BRAGA, Paula Sarno; OLIVEIRA, Rafael. Curso de Direito Processual Civil vol.2. Salvador: Juspodivm, 2009, pp.94-95

${ }^{201}$ KNIJNIK, Danilo. As (perigosíssimas) doutrinas do 'ônus dinâmico da prova' e da 'situação do senso comum' como instrumentos para assegurar o acesso à justiça e superar a probatio diabólica. Processo e Constituição: Estudos em Homenagem ao Professor José Carlos Barbosa Moreira. São Paulo: RT,2006, p.943

${ }^{202}$ Ibidem, p. 945

${ }^{203}$ LÉPORI WHITE, Inês. Cargas Probatórias Dinámicas.In.: PEYRANO, Jorge W.(dir.); LÉPORI WHITE, Inês (coord.). Cargas probatorias dinámicas. Buenos Aires: Rubinzal-Culzoni, 2004. p.65. Tradução livre.
} 
Knijnik $^{204}$ e revelam a obrigação que tem as partes de atuar no processo com lealdade, probidade e boa-fé, colaborando, inclusive para revelar a verdade dos fatos e cooperar com o órgão jurisdicional na busca de uma sentença justa. ${ }^{205}$ Nesse sentido também Alexandre Câmara vê a distribuição dinâmica do ônus da prova como decorrência do princípio da colaboração, solidariedade e boa-fé ${ }^{206}$.

Sintetizando os fundamentos em prol da aplicação da teoria do ônus dinâmico da prova, Eduardo Cambi leciona que "a facilidade da demonstração da prova, em razão desses argumentos de ordem técnica, promove, adequadamente, a isonomia entre as partes (art. 125, inc. I, CPC), bem como ressalta o princípio da solidariedade, presente, no sistema processual, no dever dos litigantes contribuírem com a descoberta da verdade (arts. 14, inc. I, e 339 do CPC), na própria exigência da litigância de boa-fé (v.g., arts. 17, 129 e 273 , inc. II, do CPC) e no dever de prevenir ou reprimir atos contrários à dignidade da justiça (arts. 125, inc. III, e 600 do CPC). ${ }^{207}$

Inês Lépori White igualmente resumindo as tendências dos tribunais argentinos aponta os seguintes fundamentos para a teoria da distribuição dinâmica do ônus da prova, quais sejam concepção dinâmica do processo, concretização da justiça, busca de soluções justas para o caso, permitir o justo equilíbrio entre as partes, critério de equidade na relação processual, deveres de lealdade, probidade e boa fé, dever das partes de colaborar com o esclarecimento da verdade, dever de cooperação dos profissionais. ${ }^{208}$

Da conjunção de todos esses princípios pode-se dizer que a teoria da distribuição do ônus da prova está calcada na preocupação contemporânea com a busca da verdade substancial e possível, no acesso efetivo à justiça, na promoção da igualdade material

\footnotetext{
${ }^{204}$ KNIJNIK, Danilo. Ob.cit, p. 945

205 AIRASCA, Ivana María. "Reflexiones sobre la doctrina de las Cargas Probatorias Dinámicas. In.: PEYRANO, Jorge W.(dir.); LÉPORI WHITE, Inês (coord.). Cargas probatorias dinámicas. Buenos Aires: Rubinzal-Culzoni, 2004, p.141

${ }^{206}$ CÂMARA, Alexandre Freitas. Doenças Preexistentes e ônus da prova: o Problema da Prova Diabólica e uma possível solução". Revista Dialética de Direito Processual. São Paulo: Dialética, 2005, n.31, p.15

${ }^{207}$ CAMBI, Eduardo Augusto Salomão. A prova civil: admissibilidade e relevância. São Paulo: Editora Revista dos Tribunais, 2006, p.342
} 
das partes bem assim nos princípios da lealdade, boa-fé, e de colaboração das partes no processo.

\section{Críticas à doutrina do ônus dinâmico da prova}

Causaria espanto se uma teoria como a da distribuição dinâmica do ônus da prova não sofresse críticas ou lhe fossem apontados óbices à sua adoção. Uma primeira preocupação apontada diz respeito à ausência texto expresso de lei legitimando sua aplicação, o que se responde facilmente até com base em diversas legislações processuais que não contêm de forma expressa a regra clássica de distribuição do ônus da prova. ${ }^{209}$ Igualmente não se tratando a lei de única fonte do direito é facilmente rechaçado esse tipo de argumento.

$\mathrm{Na}$ doutrina pátria Eduardo Cambi é o autor que novamente fornece subsídios para o afastamento desse tipo de óbice. No entendimento desse autor o próprio poder do juiz na condução do processo para a busca da obtenção da verdade real e a "interpretação conjunta do disposto nos artigo $5^{\circ}$, caput, XXXV e LIV, da CRFB/1988 e nos artigos 14, 16, 17, 18, 125, I e III, 339, 340, 342, 345, 355, todos do Código de Processo Civil, corolários dos Princípios da Igualdade, Lealdade, Boa-Fé e Veracidade, Solidariedade com o Órgão Judicial, Devido Processo Legal e Acesso à Justiça" ${ }^{210}$ já se mostram suficientes para a aplicação da teoria do ônus dinâmico da prova, que prescinde, portanto de positivação legal.

Outra crítica formulada diz respeito à surpresa e ao inconveniente processual que pode ser causada a uma das partes na medida em que não saberia previamente

\footnotetext{
${ }^{208}$ LÉPORI WHITE, Inês. Ob.cit. p.69

${ }^{209}$ BARACAT, Edgar J. "Estado actual de la teoria de la carga dinâmica de la prueba com especial referencia a antecedentes jurisprudenciales y a la matéria juzgada". In.: PEYRANO, Jorge W.(dir.); LÉPORI WHITE, Inês (coord.). Cargas probatorias dinámicas. Buenos Aires: Rubinzal-Culzoni, 2004, pp.278-279

${ }^{210}$ CAMBI, Eduardo Augusto Salomão. Tese para o Encontro Estadual do Ministério Público do Paraná. Disponível em: www.ceaf.mp.pr.gov.br/arquivos/File/teses09/EduardoCambi1.pdf. Acesso em 13 de janeiro de 2010.
} 
de maneira explícita que deveria ter produzido certa prova no feito, o que inclusive afetaria o princípio do devido processo legal.

Como modo de afastar o perigo desse procedimento, com o qual não concorda na medida em que no seu entender é demasiado inquisitivo, Falcón aponta a propriedade da disposição do art.366 do Anteprojeto de Código Processual Civil e Comercial da província de Buenos Aires que estabelecer as regras a observar nos casos em que seja possível a aplicação da carga probatória dinâmica. ${ }^{211}$

De fato em observância ao devido processo legal a parte deve ser advertida pelo juízo de suas conclusões acerca da distribuição do ônus da prova. Diferencia-se aqui a questão da inversão legal do ônus da prova em que as partes tem a ciência de seus deveres e ônus processuais e a questão da distribuição primária e dinâmica do ônus realizada pelo magistrado. A fim de possibilitar a receptividade total da teoria dinâmica impõe-se a observância dessa regra não só como regra de julgamento como também regra de procedimento, com ciência antecipada às partes ${ }^{212}$.

${ }^{211}$ FALCÓN, Enrique M. Tratado de La Prueba. Buenos Aires: Editorial Ástrea, 2003, pp. 279/280 Art.366 del anteproyecto de Código Procesal Civil y Comercial para la provincia de Buenos Aires: "Cada una das partes deberá probar el presupuesto de hecho de la norma o normas que invocare como fundamento de su pretensión, defensa o excepción. Si la ley extranjera es invocada por alguna de las partes no hubiere sido probada, el juez deberá investigar su existencia, y aplicarla a la relación jurídica materia del litigio. En los casos en que el interés comprometido lo requiera, por su gravedad, tutela especial o prioritaria, los jueces dispondrán de amplios poderes de investigación, sin perjuicio del respeto al principio de contradicción y de los proprios del debido proceso legal. Las directivas para el juez contenidas en esta norma se adecuarán, asimismo, a una mayor exigencia del deber de colaboración de las partes, según les sea a éstas más cómodo aportar las evidencias y esclarecer las circunstancias de los hechos controvertidos o si, por razón de la habitualidad, especialización u otras condiciones, la atención de la carga ha de entenderse que es a esa parte a quien corresponde, según las particularidades del caso. La distribución de la carga de la prueba no obstará a la iniciativa probatoria del tribunal, ni a la apreciación, conforme con las reglas de sana crítica, de las omisiones, deficiencias de la prueba o ausencia de colaboración debida. El juez o tribunal indicarán, concretamente, cuáles medios de prueba relevantes o de significación fundan principalmente su decisión. A falta de reglas generales expresas, el juez o tribunal, aplicarán las de la experiencia común, extraída de su propia cultura, conocimiento y observación de lo que normalmente se hace. Los jueces o tribunales deberán obrar de manera activa a fin de acceder a la verdad jurídica material y al debido esclarecimiento de la causa"

${ }^{212}$ Nesse sentido, DIDIER JR, Fredie; BRAGA, Paula Sarno; OLIVEIRA, Rafael. Curso de Direito Processual Civil vol.2. Salvador: Juspodivm, 2009, p.97; CÂMARA, Alexandre Freitas. Doenças Preexistentes e ônus da prova: o Problema da Prova Diabólica e uma possivel solução”. Revista Dialética de Direito Processual. São Paulo: Dialética, 2005, n.31, p.11; MARINONI, Luiz Guilherme. Formação da convicção e inversão do ônus da prova segundo as peculiaridades do caso concreto. Revista dos Tribunais. São Paulo/SP, v. 862, pp. 11-21, ago. 2007,p.05-06 
Danilo Knijnik trata da matéria como requisito procedimental à aplicação da teoria dinâmica do ônus da prova. Ensina o autor que:

"De fato, caso dinamizado o ônus após o encerramento da instrução, sem oportunizar aos litigantes a produção de prova, complementar ou não, ter-se-ia a situação de ofensa ao princípio do contraditório (...) É dizer, o juiz, caso entenda por bem dinamizar o ônus, deverá previamente intimar as partes a respeito, fundamentando sua decisão, sob pena de caracterizar-se retroatividade oculta. Somente assim se poderá conciliar a dinamização com o princípio da segurança jurídica (...)". 213

$\mathrm{Na}$ Argentina um grande crítico da teoria da carga probatória dinâmica é Maximiliano García Grande que em síntese afirma que ante a ausência de prova o magistrado não dever dar razão simplesmente ao autor e tampouco deve o juiz sentenciar sem ater-se a regras rígidas pois isto comprometeria a segurança jurídica das partes. ${ }^{214}$

\section{Campo de aplicação}

Como leciona Inés Lépori White a teoria da carga probatória dinâmica na Argentina é aplicável a todos os tipos de situações fáticas, casos extremados de difícil comprovação para a vítima, melhor aptidão ou comodidade para prestar ajuda no esclarecimento da verdade a quem tem o controle das coisas objeto do contratado, a natureza da relação que deu origem à obrigação, o fato do príncipe, responsabilidade fundada na culpa e quanto às matérias, nas mais diversas, desde acidentes de trânsito, concurso, contrato de depósito, contratos de trabalho, direito bancário, falsificação de cheques, locação de obra, responsabilidade contratual e extracontratual, responsabilidade médica, seguridade social, simulação, títulos de crédito. ${ }^{215}$

\footnotetext{
${ }^{213}$ KNIJNIK, Danilo. Ob.cit, p.948

214 GARCÍA GRANDE, Maximiliano. Cargas Probatórias Dinâmicas: Ni nuevas, ni argentinas, ni aplicables. Disponível em www.e-derecho.org.ar/congresoprocesal/cargas\%20DinE1micas\%20grande_.pdf

${ }^{215}$ LÉPORI WHITE, Inês. Cargas Probatórias Dinámicas.In.: PEYRANO, Jorge W.(dir.); LÉPORI WHITE, Inês (coord.). Cargas probatorias dinámicas. Buenos Aires: Rubinzal-Culzoni, 2004 pp.69-70
} 
Falcon embora seja crítico da teoria das cargas probatórias dinâmicas, entendendo-a, na verdade como uma variante do princípio favor probationis, esclarece que esta tem se concretizado em vários ramos inclusive distintos do cível, afirmando inclusive que no direito do trabalho argentino desde antigamente a carga da prova recai sobre a parte com melhores condições de dela se desvencilhar e que geralmente é o empregador, apontando, inclusive os artigos 23,55 e 57 da lei de contrato de trabalho. Neste ponto o jurista argentino faz importante observação quanto ao fato desses aspectos acima apontados terem sido obscurecidos ao serem considerados insertos na concepção de inversão do ônus da prova. ${ }^{216}$ Com efeito, como visto ponto precedente o instituto da carga probatória dinâmica não se confunde com a inversão do ônus da prova.

Na doutrina nacional ainda não se chegou a esse ponto aprofundamento de questionamento, ou seja, em que matérias ou até mesmo em que ramos do direito processual seria possível a aplicação da carga probatória dinâmica, sendo escopo fundamental deste trabalho averiguar-se a admissibilidade da recepção da teoria da distribuição do ônus da prova em matéria trabalhista.

\section{Consolidação e projeção da teoria da distribuição dinâmica no direito estrangeiro}

A chamada Teoria Dinâmica de Distribuição do Ônus da Prova na sua concepção moderna tem registrado seu pioneirismo na Argentina sendo muito difundida e bem aceita no meio jurídico, sobretudo no campo da responsabilidade profissional, apresentando uma trajetória firme, apesar da lenta evolução. ${ }^{217}$

Jorge W. Peyrano, jurista a quem se atribui o título de precursor da teoria, ao fazer a avaliação da situação da recepcionabilidade das cargas probatórias dinâmicas afirma que o ostracismo subsiste ainda no plano legislativo, embora importante legislação externa já a

\footnotetext{
${ }^{216}$ FALCÓN, Enrique M. Tratado de La Prueba. Buenos Aires: Editorial Ástrea, 2003, p.279

${ }^{217}$ PEYRANO, Jorge W. "De la cargas probatoria dinámica embozada a sua consagración legislativa In.: PEYRANO, Jorge W.(dir.); LÉPORI WHITE, Inês (coord.). Cargas probatorias dinámicas. Buenos Aires: Rubinzal-Culzoni, 2004, p.169
} 
adote, fazendo referência à Ley de Enjuyciamento Civil da Espanha. Mas para o autor nem a consagração legislativa e tampouco a inércia da jurisprudência inibem que a teoria viva e opere no mapa jurídico argentino. ${ }^{218}$

A concepção de dinamização do ônus da prova também não é descartada na Alemanha. Carlos Alberto Carbone baseando-se nas lições de Hanns Prütting ${ }^{219}$ afirma que desde sempre fora conhecida naquele país a ideia de carga probatória dinâmica, podendo operar por meio de indícios, prova indireta e presunções. Seu campo de aplicação na Alemanha, segundo interpretação de casos perante do Suprimo Tribunal de Justiça Alemão diz respeito às questões de responsabilidade médica em caso de culpa gravíssima, responsabilidade nas relações de consumo, casos de condições gerais de contratação, contratos financeiros (consumidor e entidade financeira), meio ambiente e por fim, no que nos interessa no Direito do Trabalho. ${ }^{220}$ Registre-se, por oportuno, que no direito alemão não existe norma similar à do art.333 do CPC brasileiro, utilizando-se a doutrina alemã da Normentheorie ${ }^{221}$.

Na Espanha, o relato da inclusão das inovações em matéria de ônus da prova na Ley de Enjuiciamiento Civil espanhola realizado por Marcos Peyrano nos dá conta da influência da teoria da carga probatória dinâmica no próprio direito processual espanhol, bem assim da responsabilidade da jurisprudência por essa inserção legislativa especialmente em razão de sua evidente utilidade no momento de sentenciar. ${ }^{222}$

Assim dispõe o art.217 da LEC 2000:

\footnotetext{
${ }^{218}$ PEYRANO, Jorge W. Ob.cit. p.173

${ }^{219}$ PRÜTTING, Hanns.Beweisprobleme im Arzthaftungsprozess, Problemas de la prueba em el proceso por resonsabilidad médica. Festschrif 150 Jahre Landgericht Saarbrüken, 1985.

${ }^{220}$ CARBONE, Carlos Alberto. "Cargas Probatorias Dinámicas: una mirada al derecho comparado y novedosa ampliación de su campo de acción. In.: PEYRANO, Jorge W.(dir.); LÉPORI WHITE, Inês (coord.). Cargas probatorias dinámicas. Buenos Aires: Rubinzal-Culzoni, 2004, p.210.

${ }^{221}$ MARINONI, Luiz Guilherme; ARENHART, Sérgio Cruz. Curso de Processo Civil. V.2". São Paulo, Ed. RT.2007, p.268.

${ }^{222}$ PEYRANO, Marcos L. La Teoria de Las "Cargas Probatorias Dinâmicas" em la flamante Ley de Enjuiciamento Civil Española (Ley 1/2000). In.: PEYRANO, Jorge W.(dir.); LÉPORI WHITE, Inês (coord.). Cargas probatorias dinámicas. Buenos Aires: Rubinzal-Culzoni, 2004, pp.187-193.
} 
Artículo 217. Carga de la prueba.

1. Cuando, al tiempo de dictar sentencia o resolución semejante, el tribunal considerase dudosos unos hechos relevantes para la decisión, desestimará las pretensiones del actor o del reconviniente, o las del demandado o reconvenido, según corresponda a unos u otros la carga de probar los hechos que permanezcan inciertos y fundamenten las pretensiones.

2. Corresponde al actor y al demandado reconviniente la carga de probar la certeza de los hechos de los que ordinariamente se desprenda, según las normas jurídicas a ellos aplicables, el efecto jurídico correspondiente a las pretensiones de la demanda y de la reconvención.

3. Incumbe al demandado y al actor reconvenido la carga de probar los hechos que, conforme a las normas que les sean aplicables, impidan, extingan o enerven la eficacia jurídica de los hechos a que se refiere el apartado anterior.

4. En los procesos sobre competencia desleal y sobre publicidad ilícita corresponderá al demandado la carga de la prueba de la exactitud y veracidad de las indicaciones y manifestaciones realizadas y de los datos materiales que la publicidad exprese, respectivamente.

5. Las normas contenidas en los apartados precedentes se aplicarán siempre que una disposición legal expresa no distribuya con criterios especiales la carga de probar los hechos relevantes.

6. Para la aplicación de lo dispuesto en los apartados anteriores de este artículo el tribunal deberá tener presente la disponibilidad y facilidad probatoria que corresponde a cada una de las partes del litigio. (g.n.)

O art. 217 da Lei espanhola após enumerar as regras clássicas ou estáticas do ônus da prova (em especial itens 2 e 3 do artigo 217), passa a prever a possibilidade de flexibilização dessas mesmas regras no item 6 de modo a consagrar a doutrina do ônus dinâmico da prova demonstrando uma posição legislativa de vanguarda no tema. ${ }^{223}$

No que tange especificamente ao item 7 do art.217 autores espanhóis afirmam que se deve levar em conta a disponibilidade e finalidade probatória de cada parte de modo que o ônus da prova se imponha a quem mais facilmente o assimile, o que deve ser

${ }^{223}$ PEYRANO, Marcos L. La Teoria de Las "Cargas Probatorias Dinâmicas" en la flamante Ley de Enjuiciamento Civil Española (Ley 1/2000). In.: PEYRANO, Jorge W.(dir.); LÉPORI WHITE, Inés (coord.). Cargas probatorias dinámicas. Buenos Aires: Rubinzal-Culzoni, 2004, pp.191-192. 
aplicado especialmente ao processo do trabalho onde a desigualdade social inerente às partes litigantes se estende também as questões probatórias. ${ }^{224}$

Igualmente Marcelo Lopez-Mesa, outro jurista argentino, comenta que a doutrina das cargas probatórias dinâmica não constituía nenhuma novidade na Espanha, que já vinha considerando que as normas de distribuição da carga da prova deveriam se adaptar a cada caso, não se lhes aplicando princípios inflexíveis. Apontamento interessante das observações do autor diz respeito ao entendimento do Tribunal Constitucional espanhol no sentido de que "quando as fontes de prova se encontrem em poder de um das partes do litígio, a obrigação constitucional de colaborar com os Tribunais no curso do processo - art.118 da Constituição Espanhola - leva a que tal parte seja quem deva aportar os dados requeridos a fim de o órgão judicial possa descobrir a verdade" 225

Nesse sentido de relativização do ônus estático da prova a seguinte decisão, com a observação de que antes do advento da Ley de Enjuiciamento Civil espanhola o tratamento do ônus da prova era dado através do Código Civil Espanhol em seu art.1214:

"La jurisprudência há venido flexibilizando el rigor de la regla del art.1214 CC haciendo recaer las consecuencias de la falta de la prueba sobre la parte que tênia más facilidad o se hallaba em uma posición prevalente o más favorable por la disponibilidad o proximidad a la fuente de prueba. Esta doctrina de la facilidad y disponibilidad probatória há sido asumida por el art.217.6 LEC 2000 (Tribunal Supremo, Sala Primera, de lo Civil,Sentencia de 23 Dic.2002, Rec.17611997, Ponente: Corbal Fernández) COLEX-DATA 814 2003 ", ${ }^{226}$ (g.n.)

Diante da magnitude do universo jurisprudencial já produzido na esfera cível espanhola, não pretende este tópico manifestar nada mais que alguns breves apontamentos

\footnotetext{
${ }^{224}$ MONTESMOS, Ignácio A; MELLADO, Carlos L.A; PELLICER, Angel B; PESET, José M.G. Derecho Procesal Laboral. Valencia: Tenant to Blanch, 2007, pp.183-184.

${ }^{225}$ LÓPEZ-MESA, Marcelo J. La carga de la prueba en ciertos casos de responsabilidad civil (La doctrina de las cargas probatorias dinámicas en la jurisprudencia argentina y española). In www.eft.com.ar/DOCTRINA/articulos/libros-carga_de_la_prueba. Acesso em 6/11/2007.(Tradução livre da autora)

226 In: Ley de Enjuiciamento Civil. ROMAN HERNANDEZ, José Ignácio San; SÁNCHEZ MATA, Almudena. Colex Data.Wolkers Kluwer España, 2005 in Google.books, Acesso em 05.01.2010.
} 
sobre outro aresto, desta feita na esfera trabalhista, colhido através de pesquisa realizada na Internet no sítio do poder judiciário espanhol, cuja parte da fundamentação que nos interessa segue transcrita:

"ROJ: STS 6487/2009

\begin{tabular}{|c|c|c|c|c|}
\hline \\
\hline \multicolumn{5}{|l|}{$\begin{array}{l}\text { Tipo Órgano: } \\
\text { Municipio: }\end{array}$} \\
\hline Ponente: & JOAQUIN & SAMI & ER & JUA \\
\hline $\mathbf{N}^{\mathbf{o}}$ Recurso: & $3409 / 2008$ & $3409 / 2008$ & -- Fecha: & 23/09/2009 \\
\hline Tipo & Resc & ción: & & Senten \\
\hline
\end{tabular}

Resumen: Indemnización de daños por vulneración de derechos fundamentales.

(...)

SEXTO.- Es cierto que, conforme al principio general de la carga de la prueba, corresponde a la parte actora probar la certeza de los hechos de los que ordinariamente se desprende, según las normas jurídicas, el efecto jurídico correspondiente a las pretensiones de su demanda (artículo 216.2 de la Ley de Enjuiciamiento Civil ). Pero, aparte de las excepciones que la propia ley establece en orden a la tutela antidiscriminatoria y la protección de los derechos fundamentales (artículos 96 y 179 de la Ley de Procedimiento Laboral), la doctrina jurisprudencial ha venido aplicando con carácter excepcional un critério alternativo de carácter corrector, ponderando las especiales dificultades probatorias de determinados hechos y la posición de las partes ante los medios de prueba. Así, por ejemplo, en materia de reincorporación de la excedencia, nuestra sentencia de 6 de octubre de 2005 (rcud. 3876/2004) señala, continuando una línea doctrinal anterior, que "la norma distributiva de la carga de la prueba no responde a unos principios inflexibles, sino que se deben adaptar a cada caso según la naturaleza de los hechos afirmados o negados y la disponibilidad o facilidad para probar que tenga cada parte. Criterio éste que en la actualidad ya viene legalmente consagrado, al establecer el apartado 6 del tan citado art. 217 de la LEC vigente, tras haber suministrado determinadas reglas concretas acerca de la carga probatoria, que "para la aplicación de lo dispuesto en los apartados anteriores de este artículo, el tribunal deberá tener presente la disponibilidad y facilidad probatoria que corresponde a cada una de las partes del litigio". Conforme a este principio se concluye que no cabe duda acerca de que en el caso ES Correos, y no la trabajadora, quien tiene la mayor disponibilidad de los elementos probatorios acerca de la existencia o inexistencia de determinada vacante en un momento concreto, no sólo porque a su alcance se encuentra la pertinente documentación, sino además porque la posible inexistencia, pese a tratarse de unhecho negativo, puede perfectamente probarla, en el caso de ser cierta, por cualquiera de los demás medios admitidos en derecho, entre ellos la testifical a cargo del personal conocedor del hecho".

SEPTIMO.- En el presente caso se cumplen las exigencias para ese desplazamiento de la carga de la prueba, pues, por una parte, es evidente la dificultad probatoria de la trabajadora para acreditar las incidencias de la gestión de las listas y en, particular, las personas contratadas y su calificación de 
acuerdo con el baremo. Por otra parte, la posición de la empresa en orden al control y disposición de la prueba sobre los procesos de selección facilita extraordinariamente su acceso y utilización de los instrumentos correspondientes. Por ello, la entidad empleadora no puede limitarse a indicar que "no se ha acreditado el derecho a ser contratado" en atención a "los contratos ${ }_{227}^{q u e}$ le hubieran correspondido "por el orden que ocupaba (sic) en las listas".(gn.)

Da leitura da parte destacada da decisão fica evidente a opção pela aplicação da carga probatória dinâmica em especial nas questões trabalhistas fundamentais. Com efeito, o julgador após invocar as disposições da legislação laboral espanhola, socorre-se da previsão do art.217.6 da LEC para entender que no caso analisado a carga da prova deve deslocar-se da autora que tem evidente dificuldade probatória para empregadora que tem o controle e a disposição sobre o processo de seleção dos empregados. Reafirma, pois, o julgado a tendência contemporânea de que os critérios de distribuição do ônus da prova não podem mais ser aqueles critérios inflexíveis de um passado com influência nitidamente liberal.

Em resumo e como tendência jurisprudencial na Espanha pode-se dizer que nesse país a) as partes não podem se esconder na negativa das alegações da parte contrária; b) o ônus da prova pode recair sobre qualquer das partes conforme sua situação processual e as circunstâncias do caso; c) o ônus da prova depende da possibilidade de produzi-la; d) a distribuição dinâmica do ônus da prova consiste em atribuir esse ônus a quem por sua situação esteja em melhores condições de trazer a prova aos autos, repita-se, independentemente de sua condição de autor ou réu; e) fatores como a superioridade técnica, situação de melhor aptidão probatória, índole ou complexidade do fato a prova, geram o deslocamento do ônus da prova para quem esteja em melhores condições para cumpri-lo. ${ }^{228}$

\footnotetext{
${ }^{227}$ In: $\underline{\text { www.poderjudicial.es, }}$ acesso em 10 de janeiro de 2010.

228 CARBONE, Carlos Alberto. "Cargas Probatorias Dinámicas: una mirada al derecho comparado y novedosa ampliación de su campo de acción. In.: PEYRANO, Jorge W.(dir.); LÉPORI WHITE, Inés (coord.). Cargas probatorias dinámicas. Buenos Aires: Rubinzal-Culzoni, 2004, p.212
} 
O Código Geral de Processo do Uruguai (Ley no. 15.982 de 18/10/88, com vigência a partir de 20/11/1989) trata-se de um código processual unificado, nos interessando a princípio as seguintes disposições no seu conjunto:

\section{"Artículo 139. - Carga de la prueba}

139.1 Corresponde probar, a quien pretende algo, los hechos constitutivos de su pretensión; quien contradiga la pretensión de su adversario tendrá la carga de probar los hechos modificativos, impeditivos o extintivos de aquella pretensión.

139.2 La distribución de la carga de la prueba no obstará a la iniciativa probatória del tribunal ni a su apreciación, conforme con las reglas de la sana crítica, de las omisiones o deficiencias de la prueba.

\section{Artículo 341. Contenido de la audiencia preliminar}

(...)

6) Fijación definitiva del objeto del proceso y de la prueba; pronunciamiento sobre los medios de prueba solicitados por las partes, rechazando los que fueren inadmisibles, innecesarios o inconducentes (artículo 24.6), disponiéndose la ordenación y diligenciamiento de los que correspondan; recepción de los que fuere posible diligenciar en la propia audiencia y fijación de otra complementaria para el diligenciamiento de los restantes, acordándose lo necesario para que en ocasión de esa audiencia complementaria se diligencien totalmente las pruebas que no se hubieren recibido en la audiencia preliminar (artículo 343.1).

Artículo 350.3 En las pretensiones propias de la materia laboral, agraria y demás de carácter social, no obstante lo dispuesto en el numeral $1^{\circ}$ del artículo 341 , se podrá modificar la pretensión en la audiencia preliminar, cuando resulte, manifiestamente, que carencias de información o de asesoramiento han determinado omisiones em relación a derechos que asisten a la parte. En estos casos, el tribunal otorgará a la contraparte oportunidades para la adecuada contestación; se podrá, a tales efectos prorrogar la audiencia, si las nuevas cuestiones son de hecho y no fuere posible controvertirlas, sin previa información

O Código de Processo do Uruguai, para o Professor Santiago Pereira Campos da Faculdade de Montevidéu, tem critério bem amplo para o acolhimento da prova, aceitando praticamente todos os seus meios, mas para esse autor há uma especialidade que não está ali prevista e que é justamente a admissão, no processo trabalhista, do princípio da disponibilidade da prova, que para alguns é qualificado como princípio das cargas dinâmicas da prova. Princípio segundo o qual “o empregador tem o ônus de proporcionar em juízo os elementos probatórios (especialmente os documentos que a lei lhe obriga a levar) e sua omissão se sanciona dando por provados os fatos que deveriam ser comprovados através daquele meio de prova". Continua o mesmo autor ensinando que "em matéria de prova é 
talvez onde mais se note a presença dos princípios substanciais. Assim, no momento de valorar a prova os juízes recorrem ao princípio da razoabilidade, da primazia da realidade ou ao princípio protetor, em que pensem não estarem expressamente contemplados no Código Processual." 229

Tem-se em conclusão que o Código Processual Uruguaio não faz menção explícita à teoria da distribuição dinâmica do ônus da prova, partindo, inicialmente das regras clássicas, mas admitindo a relativização das mesmas a teor do que preconiza o próprio art.350.3 denotando, pelos seus termos, a consciência do legislador relativamente a existência de carência de informação e de assistência na seara laboral.

\subsection{O Código Modelo de Processos Coletivos para a Ibero-América}

Em 1957 após a realização em Montevidéu das Primeiras Jornadas latinoamericanas de Direito Processual foi fundado o Instituto Ibero americano de Direito Processual. Alguns anos depois nas Jornadas realizadas no ano de 1967, desta feita na Venezuela restou decidida a realização de dois projetos de normas processuais tendo como campo de aplicação os países latino-americanos. Esse compromisso, após o trabalho de comissões de juristas, culminou na elaboração dos Códigos Modelos de Processo Penal e de Processo Civil e de Processo Penal, aprovados por ocasião das Jornadas realizadas no Rio de Janeiro em 1988. Registre-se que nos anos que se seguiram esses códigos-modelo influenciaram a legislação de vários países. Somente em 2004, entretanto, viria à baila o Anteprojeto de Código Modelo de Processos Coletivos para a Ibero-América, com a nítida preocupação de melhor efetivar a tutela jurisdicional nessa seara tão importante do direito. ${ }^{230}$

229 PEREIRA CAMPOS, Santiago. El proceso laboral en Uruguay. Revista internauta de practica jurídica, no. 11, 2002, tradução livre da autora.

${ }^{230}$ MENDES, Aluisio Gonçalves de Castro. O Código Modelo de Processos Coletivos do Instituto IberoAmericano de Direito Processual. Disponível na internet: http://www.mundojuridico.adv.br $>$. Acesso em 5 de janeiro de 2010, p.01 
No que tange ao objeto deste trabalho a proposição de Código Modelo para Processos Coletivos é de extrema importância, vez que recepciona, sem sombra de dúvidas, a teoria da carga probatória dinâmica em seu texto, abaixo transcrito:

Art. 12. Pruebas.- Son admisibles en juicio todos los medios de prueba, incluida la prueba estadística o por muestreo, siempre que sean obtenidos por medios lícitos.

Par. $1^{o}$ - La carga de la prueba incumbe a la parte que posea conocimientos científicos, técnicos o informaciones específicas sobre los hechos, o mayor facilidad para su demostración. Sin embargo, si por razones de orden económico o técnico, dicha carga no pudiere ser cumplida, el juez impartirá las órdenes necesarias para suplir la deficiencia y obtener los elementos probatorios indispensables para proferir un fallo de mérito, pudiendo requerir pericias a entidades públicas cuyo objeto estuviere ligado a la materia en debate, condenándose al demandado perdidoso al reembolso de los emolumentos devengados. Si a pesar de lo anterior, no es posible aportar la prueba respectiva, el juez podrá ordenar su práctica con cargo al Fondo de los Derechos Difusos e Individuales Homogéneos.

Par. $\mathbf{2}^{o}$ - Durante la fase de instrucción, si surgieren modificaciones de hecho o de derecho relevantes para el juzgamiento de la causa, el juez podrá rever, en decisión fundada, la distribución de la carga de la prueba, y conceder a la parte a quien le fue atribuida un plazo razonable para la producción de la prueba, respetando las garantías del contradictorio en relación a la parte contraria.

Par. $3^{\circ}$ - El juez podrá ordenar de oficio la producción de pruebas, con el debido respeto de las garantías del contradictorio. ${ }^{231}$ (g.n.)

231 Art. 12. Provas - São admissíveis em juízo todos os meios de prova, desde que obtidos por meios lícitos, incluindo a prova estatística ou por amostragem.

Par. $\mathbf{1}^{\mathbf{0}}$. O ônus da prova incumbe à parte que detiver conhecimentos técnicos ou informações específicas sobre os fatos, ou maior facilidade em sua demonstração. Não obstante, se por razões de ordem econômica ou técnica, o ônus da prova não puder ser cumprido, o juiz determinará o que for necessário para suprir à deficiência e obter elementos probatórios indispensáveis para a sentença de mérito, podendo requisitar perícias à entidade pública cujo objeto estiver ligado à matéria em debate, condenado-se o demandado sucumbente ao reembolso. Se assim mesmo a prova não puder ser obtida, o juiz poderá ordenar sua realização, a cargo ao Fundo de Direitos Difusos e Individuais Homogêneos. Par. $\mathbf{2}^{\mathbf{0}}$ - Durante a fase instrutória, surgindo modificação de fato ou de direito relevante para o julgamento da causa, o juiz poderá rever, em decisão motivada, a distribuição do ônus da prova, 
Denota-se da leitura da primeira parte parágrafo primeiro do art.12 que há um rompimento total com a distribuição prévia e abstrata do ônus da prova revolucionando o Código Modelo o tratamento da matéria do ônus da prova. Como bem observa Eduardo Cambi o juiz não se vincula mais aos critérios da posição das partes em juízo e das espécies de fatos controvertidos (aplicação clássica do ônus da prova) ${ }^{232}$. Perceba-se que não havendo a priori a imputação ou determinação da incumbência do encargo probatório a uma das partes, seja a partir de sua posição processual seja a partir da natureza dos fatos controvertidos (constitutivos, extintivos, modificativos, impeditivos), não há se falar em inversão do ônus da prova. Logo nos termos do Código Modelo para Processos Coletivos para Ibero América não há inversão da carga da prova, mas sim sua atribuição diretamente pelo magistrado consoante os pressupostos do próprio parágrafo primeiro do art.12 e sua revisão, quando necessária e desta feita com permissivo do parágrafo segundo do mesmo artigo, quando e se houverem modificações de fato ou de direito, após a devida fundamentação.

\section{Projeção da teoria da distribuição dinâmica do ônus da prova no direito nacional}

\subsection{Legislação}

$\mathrm{Na}$ legislação infraconstitucional brasileira atualmente nada há de positivado no que tange à questão da carga probatória dinâmica. O mais próximo que estávamos quanto à inclusão em lei das premissas dessa teoria eram as disposições do Anteprojeto do Código Brasileiro de Processos Coletivos de iniciativa do Instituto Brasileiro de Direito Processual e coordenado pela Professora Ada Pelegrini Grinover, bem assim o disposto no Anteprojeto de Código de Processo Coletivo concebido pelos programas de pósgraduação em Direito da Universidade do Estado do Rio de Janeiro e Universidade Estácio de Sá coordenado pelo Professor Aluísio Gonçalves Mendes. ${ }^{233}$

concedido à parte a quem for atribuída a incumbência prazo razoável para a produção da prova, observado o contraditório em relação à parte contrária. Par. $3^{\circ}$ - O juiz poderá determinar de ofício a produção de provas, observado o contraditório.

${ }^{232}$ CAMBI, Eduardo Augusto Salomão. A prova civil: admissibilidade e relevância. São Paulo:Revista dos Tribunais, 2006, p.341

${ }^{233}$ DIDIER JR, Fredie; BRAGA, Paula Sarno; OLIVEIRA, Rafael. Curso de Direito Processual Civil vol.2. Salvador: Juspodivm, 2009, p.97 
Relativamente ao encargo probatório o Anteprojeto do Código Brasileiro de Processos Coletivos de iniciativa do Instituto Brasileiro de Direito Processual percebe-se que houve um abandono ao apego total à distribuição clássica contida no artigo 333, incisos I e II do Código de Processo Civil brasileiro e optaram seus idealizadores igualmente por não utillizar apenas o tratamento dado à matéria pelo Código de Defesa do Consumidor (artigo $6^{\circ}$, inciso VII). De fato, o anteprojeto formulou bases pelas quais é possível imputar o ônus da prova à parte que detiver conhecimentos técnicos ou informações específicas sobre os fatos ou maior facilidade em sua demonstração.

Esta é na verdade uma das inovações do Anteprojeto que se destaca dentre os demais temas e que na visão de Édis Milaré e Renata Castanho foram tratados de forma sensata nas palavras destes processualistas para quem não ocorreu o afastamento da regra geral (art.333 do CPC), mas a permissão, diante do bom senso e economia processual, que a distribuição do ônus da prova seja realizada de acordo com as especificidades do caso concreto e considerando as melhores condições de uma das partes na possibilidade de produção da prova. Para esses autores inclusive a

\begin{abstract}
"flexibilidade do Anteprojeto reside on fato de reconhecer que, em determinadas situações, a prova é de difícil produção para ambas as partes, não significando a dificuldade de uma delas, necesseriamente a facilidade da outra. Nestes casos, o Anteprojeto não beneficia, de plano, o autor da ação. Pelo contrário, o autor só será desimcumbido do ônus de provar os fatos ocnstitutivos do seu direito se o réu detiver maior falcilidade para produzir a prova" 234
\end{abstract}

Para melhor visualização da questão é a seguinte a redação do art.11 do referido Anteprojeto:

\footnotetext{
${ }^{234}$ MILARÉ, Edis; CASTANHO, Renata. A distribuição do ônus da prova no Anteprojeto do Código Brasileiro de Processos Coletivos. In: GRINOVER, Ada Pellegrini Grinover; MENDES, Aluisio Gonçalves de Castro; WATANABE, Kazuo (coords.). Direito Processual Coletivo e o Anteprojeto de Código Brasileiro de Processos Coletivos.São Paulo: Revista dos Tribunais, 2007, pp.260-261
} 
Art. 11. Provas - São admissíveis em juízo todos os meios de prova, desde que obtidos por meios lícitos, incluindo a prova estatística ou por amostragem.

$\$ \mathbf{1}^{o}$ Sem prejuízo do disposto no artigo 333 do Código de Processo Civil, o ônus da prova incumbe à parte que detiver conhecimentos técnicos ou informações específicas sobre os fatos, ou maior facilidade em sua demonstração. (g.n.)

$\S 2^{\circ} O$ ônus da prova poderá ser invertido quando, a critério do juiz, for verossímil a alegação, segundo as regras ordinárias de experiência, ou quando a parte for hipossuficiente.

$\S 3^{o}$ Durante a fase instrutória, surgindo modificação de fato ou de direito relevante para o julgamento da causa (parágrafo único do artigo $5^{\circ}$ deste Código), o juiz poderá rever, em decisão motivada, a distribuição do ônus da prova, concedendo à parte a quem for atribuída a incumbência prazo razoável para sua produção, observado o contraditório em relação à parte contrária (artigo 25, parágrafo $5^{\circ}$, inciso IV).

$\S 4^{o}$. O juiz poderá determinar de ofício a produção de provas, observado o contraditório.

$\$ 5^{\circ}$. Para a realização de prova técnica, o juiz poderá solicitar a elaboração de laudos ou relatórios a órgãos, fundações ou universidades públicas especializados na matéria.

Nos termos acima propostos pelo Anteprojeto subsiste a referência inicial à distribuição clássica (primeira parte do parágrafo primeiro), o que associado ao disposto no parágrafo segundo denota que não houve a assumpção da teoria dinâmica para todos os casos, o que mereceu, nesse ponto, acertada crítica de Marcelo Abelha Rodrigues no sentido de que “(a) poderia o Anteprojeto usar a carga dinâmica da prova para todos os casos (de hipossuficiência ou não) sempre que o material probatório possa ser melhor produzido por uma das partes, banindo de vez a regra preestabelecida de distribuição do ônus da prova. Enfim, o ônus probatório seria sempre fixado no despacho saneador (art.23,parágrafo quinto, V, do Anteprojeto); (b) o ônus subjetivo da prova previsto no art.333, I e II, seria banido do sistema",235

${ }^{235}$ RODRIGUES, Marcelo Abelha. A distribuição do ônus da prova no Anteprojeto do Código Brasileiro de Processos Coletivos. In: GRINOVER, Ada Pellegrini Grinover; MENDES, Aluisio Gonçalves de Castro; WATANABE, Kazuo (coords.). Direito Processual Coletivo e o Anteprojeto de Código Brasileiro de Processos Coletivos. São Paulo: Revista dos Tribunais, 2007, p.253 
A inovação, em contraste com as regras de distribuição do encargo probatório consiste, em síntese, no Anteprojeto no dever das próprias partes revelar os conhecimentos científicos e informações pertinentes ao caso, a partir não só de suas alegações, mas considerando também as da parte contrária. Aquele que detenha os conhecimentos técnicos ou informações específicas bem assim uma maior facilidade na demonstração dos fatos passa a ser o incumbido do ônus probatório.

Eduardo Cambi apresenta crítica veemente ao tratamento que deu à matéria o Anteprojeto de Código Brasileiro de Processo Coletivo, vez que ao inserir técnica similar ao do artigo $6^{\circ}$, inc. VIII, do Código de Defesa do Consumidor no parágrafo segundo do art.11 afastou-se completamente do ideário do Código-Modelo de Ibero America. Para o autor não há qualquer sentido na mistura das técnicas - inversão do ônus da prova e teoria da distribuição dinâmica do ônus da prova, sendo salutar, isto sim, a adoção do regramento latino americano que melhor avançou na questão. ${ }^{236}$

Nada obstante os Anteprojetos encontram-se superados pela existência atualmente do Projeto de Lei 5139/2009, que se verá no item seguinte.

\subsubsection{O Projeto de Lei 5139/2009}

O Projeto de Lei 5139 apresentado aos 29 de abril de 2009, oriundo do Anteprojeto do Código Brasileiro de Processo Coletivo e que disciplina a ação civil pública para a tutela de interesses difusos, coletivos ou individuais homogêneos, e dá outras providências, encontra-se atualmente (janeiro/2011) tramitando perante a Comissão de Constituição e Justiça e de Cidadania .

\footnotetext{
${ }^{236}$ CAMBI, Eduardo Augusto Salomão. Tese para o Encontro Estadual do Ministério Público do Paraná. Disponivel em: www.ceaf.mp.pr.gov.br/arquivos/File/teses09/EduardoCambil.pdf. Acesso em 13 de janeiro de 2010.
} 
Objetivando a sistematização dos procedimentos coletivos, foi elaborado o anteprojeto de Código Coletivo, convertendo-se, posteriormente, no recente Projeto de Lei 5139/09, elaborado por uma comissão especial do Ministério da Justiça formada por renomados juristas e advogados destacando-se sua Coordenadora a Professora Ada Pelegrini Grinover.

Registre-se que escapa ao objeto deste trabalho a realização de uma análise mais aprofundada do direito processual coletivo, importando apenas registrar o interesse da abordagem do recente projeto de Lei 5139/09 relativamente ao seu regramento específico na matéria relativa ao encargo probatório e as suas peculiaridades que interessam ao objeto deste estudo. Assim está redigido o art.20:

Art. 20. Não obtida a conciliação ou quando, por qualquer motivo, não for utilizado outro meio de solução do conflito, o juiz, fundamentadamente:

I - decidirá se o processo tem condições de prosseguir na forma coletiva;

II - poderá separar os pedidos em ações coletivas distintas, voltadas à tutela dos interesses ou direitos difusos e coletivos, de um lado, e dos individuais homogêneos, do outro, desde que a separação represente economia processual ou facilite a condução do processo;

III - fixará os pontos controvertidos, decidirá as questões processuais pendentes e determinará as provas a serem produzidas;

IV - distribuirá a responsabilidade pela produção da prova, levando em conta os conhecimentos técnicos ou informações específicas sobre os fatos detidos pelas partes ou segundo a maior facilidade em sua demonstração;

$V$ - poderá ainda distribuir essa responsabilidade segundo os critérios previamente ajustados pelas partes, desde que esse acordo não torne excessivamente difícil a defesa do direito de uma delas;

VI - poderá, a todo momento, rever o critério de distribuição da responsabilidade da produção da prova, diante de fatos novos, observado o contraditório e a ampla defesa;

VII - esclarecerá as partes sobre a distribuição do ônus da prova; e

VIII - poderá determinar de ofício a produção de provas, observado o contraditório. (gn) 
Aproxima-se o Projeto de Lei 5139/2009 do Código Modelo de Ibero America não mais fazendo menção a técnica de inversão do ônus da prova e conferindo amplos poderes ao juiz para que distribua, em audiência preliminar, a carga da prova às partes, considerando para tanto como pressupostos desta imputação os conhecimentos técnicos ou informações específicas sobre os fatos detidos ou conforme maior facilidade de demonstração dos fatos. Nos mesmos moldes do Código Modelo o critério inicial de distribuição do ônus da prova poderá ser revisto na hipótese do surgimento de fatos novos, observando-se o contraditório e a ampla defesa.

Registre-se, por fim, a opção do Projeto pela caracterização, se assim podemos dizer, da distribuição do ônus da prova como um critério de procedimento e não somente critério de julgamento na medida em que o magistrado deverá esclarecer as partes sobre a distribuição do ônus da prova nessa audiência preliminar.

Importante ressaltar também o reconhecimento dado pelo Projeto de Lei à convenção do ônus da prova pelas partes (inciso V, do art. 20), autorizando o magistrado a adotar o critério de distribuição pactuado pelas partes, desde que, por óbvio, não prejudique excessivamente o direito de defesa de qualquer delas.

Reveladora das previsões inovadoras do projeto de lei em matéria de prova é a sistematização principiológica no art. $3^{\circ}$ do dever de colaboração das partes na produção de provas. Segue a redação do artigo:

\footnotetext{
Art. 3. O processo civil coletivo rege-se pelos seguintes princípios:

I - amplo acesso à justiça e participação social;

II - duração razoável do processo, com prioridade no seu processamento em todas as instâncias;

III - isonomia, economia processual, flexibilidade procedimental e máxima eficácia;

IV - tutela coletiva adequada, com efetiva precaução, prevenção e reparação dos danos materiais e morais, individuais e coletivos, bem como punição pelo enriquecimento ilícito;
} 
$V$ - motivação específica de todas as decisões judiciais, notadamente quanto aos conceitos indeterminados;

VI - publicidade e divulgação ampla dos atos processuais que interessem à comunidade;

VII - dever de colaboração de todos, inclusive pessoas jurídicas públicas e privadas, na produção das provas, no cumprimento das decisões judiciais e na efetividade da tutela coletiva;

VIII - exigência permanente de boa-fé, lealdade e responsabilidade das partes, dos procuradores e de todos aqueles que de qualquer forma participem do processo; $e$

IX - preferência da execução coletiva. (gn)

Como já exposto no tópico relativo aos fundamentos da teoria da carga dinâmica probatória, justamente uma das bases fundadoras desse novo sistema reside justamente nos princípios de solidariedade ou colaboração. Nada obstante não podermos entender como taxativo o rol de princípios, e talvez até desnecessário diante dos princípios constitucionais do processo, sejam eles explícitos ou implícitos, a iniciativa da positivação desse dever de produção de provas é extremamente salutar.

Por fim, e não menos importante convém citar o disposto no art.68 do Projeto:

Art. 68. Os dispositivos desta Lei aplicam-se no âmbito das relações de trabalho, ressalvadas as peculiaridades e os princípios informadores do processo trabalhista.

Os termos do artigo supracitado não deixam qualquer dúvida quanto à aplicação das disposições ali previstas ao processo do trabalho. Elogiável a iniciativa principalmente porque espanca qualquer interpretação na esfera processual trabalhista quanto à aplicação subsidiária do moderno regramento da distribuição dinâmica do ônus da prova. Há que se congratular a iniciativa do Projeto de Lei 5139 nesse aspecto, aguardando sua aprovação nesses termos que bem espelham as aspirações de um processo coletivo justo e pautado na busca da verdade o mais substancial possível, com a valorização dos princípios da instrumentalidade, adequação e igualdade. 


\subsubsection{O Projeto de Lei $n^{\circ} 3.015 / 2008$}

Atento às alterações existentes, por meio das quais se vislumbrou que não apenas a doutrina mas também a jurisprudência vêm se inclinando para a aceitação da Teoria Dinâmica de Distribuição do Ônus da Prova, o legislador pátrio pretende positivar a mencionada teoria.

Para tanto aos 13 de março de 2008, o Deputado Federal Manoel Júnior pertencente ao PSB-PB apresentou o Projeto de Lei n. 3.015, justificando-o nos seguintes termos: "possibilidade de facultar ao juiz, diante da complexidade do caso, restabelecer as regras da prova consagra a referida teoria, e representa aplicação prática dos princípios constitucionais da adequação, da cooperação e da igualdade entre as partes". ${ }^{237}$

Em tramitação junto à Câmara dos Deputados o Projeto de Lei $\mathrm{n}^{\mathrm{o}}$ $3.015 / 2008$, que propõe, de acordo com o artigo $2^{\circ}$ do mencionado projeto, a alteração da redação do disposto no artigo 333 do Código de Processo Civil, para os seguintes termos: 'Art.333.O ônus da prova incumbe: I - ao autor, quanto ao fato constitutivo do seu direito; II - ao réu, quanto à existência de fato impeditivo, modificativo ou extintivo do direito do autor. $\S 1^{o}$ É nula a convenção que distribui de maneira diversa o ônus da prova quando:

I - recair sobre direito indispensável da parte; II - tornar excessivamente difícil a uma parte o exercício do direito. $\S 2^{\circ}$ É facultado ao juiz, diante da complexidade do caso, estabelecer a incumbência do ônus da prova de acordo com o caso concreto." (destaque do autor)

Observa-se da redação do $\S 2^{\circ}$ do dispositivo acima destacado, a pretensão de positivação pelo legislador brasileiro da Teoria da Distribuição Dinâmica do Ônus Probatório, criando expressamente o permissivo legal infraconstitucional apto a amparar a

${ }^{237}$ CAMBI, Eduardo Augusto Salomão. Tese para o Encontro Estadual do Ministério Público do Paraná. Disponível em: www.ceaf.mp.pr.gov.br/arquivos/File/teses09/EduardoCambil.pdf. Acesso em 13 de janeiro de 2010. 
distribuição do ônus da prova segundo cada caso concreto.

Nada obstante, também esse Projeto de Lei 3015/2008 já sofre críticas da doutrina. Tanto é assim que Eduardo Cambi aponta para a necessidade de aperfeiçoamento do disposto no parágrafo segundo do artigo supratranscrito, uma vez que o impele o magistrado a determinar a distribuição da carga da prova segundo o caso concreto não é sua complexidade, mas sim, a necessidade da "tutela de direito material, pela dificuldade de uma das partes produzir a prova, em relação à outra, que pode produzi-la com maior facilidade”. ${ }^{238}$.

Outro ponto a aperfeiçoar também diz respeito à questão da facultatividade da distribuição do ônus da prova. Aqui não pode haver opção para o magistrado, ou seja, diante de uma situação processual de desigualdade material das partes e constatada qual delas tem melhores condições de produzir a prova, em atenção à proteção do direito material em disputa há que ser aplicada a solução dinâmica na repartição do ônus, "sob pena de sua omissão ser inconstitucional, por deixar de tutelar o direito fundamental à tutela jurisdicional efetiva prevista no artigo $5^{\circ}$, inc. XXXV, da CF." 239

Omissão que poderia ser sanada neste Projeto de Lei refere-se ao reconhecimento da dimensão procedimental da distribuição dinâmica do ônus da prova, ou seja, a exemplo do que ocorre no projeto de lei relativo aos processos coletivos deveria haver previsão expressa quanto à obrigatoriedade de imputação, pelo juiz, em momento anterior à sentença, do responsável pela produção da prova de modo a evitar-se ofensa ao princípio do contraditório e assegurar a ampla defesa de quaisquer das partes.

Por fim e com relação à tramitação do mencionado Projeto de Lei $\mathrm{n}^{\mathrm{o}}$ 3.015/2008, este se encontra atualmente na Comissão de Constituição e Justiça e de Cidadania

${ }^{238}$ CAMBI, Eduardo Augusto Salomão. Tese para o Encontro Estadual do Ministério Público do Paraná. Disponivel em: www.ceaf.mp.pr.gov.br/arquivos/File/teses09/EduardoCambil.pdf. Acesso em 13 de janeiro de 2010. 
(CCJC) com relator designado desde 17/12/2008 (Deputado Flávio Dino do PC do B-MA), com movimentação em 21/12/2010, sendo devolvido sem modificações ${ }^{240}$

\subsubsection{O Anteprojeto do Novo Código de Processo Civil - atual PLS n.166/2010}

Encontra-se atualmente em trâmite no Senado Federal o Projeto de Lei do novo Código de Processo Civil trazendo inúmeras novidades dentre elas a previsão expressa da distribuição dinâmica do ônus da prova. A própria exposição de motivos já delinea a filosofia dos idealizadores do novo diploma alinhada às tendências contemporâneas de reconhecimento do processo como instrumento apto à realização efetiva do direito material do jurisdicionado numa sociedade democrática de direito ${ }^{241}$. Igualmente se percebe o ideário de valorização da Constituição refletido no projeto cuja intenção de adequação das normas processuais aos axiomas da Lei Maior. Nesse sentido o artigo primeiro do Projeto:

“ O processo civil será ordenado, disciplinado e interpretado conforme os valores e os princípios fundamentais estabelecidos na Constituição da República Federativa do Brasil,observando-se as disposiçoes deste Código".

Não houve ruptura total com o passado, aproveitando-se institutos que se mostraram exitosos para a efetividade processual e acrescentando-se novas previsões aptas àquilo que pareceu ser o foco objetivo dos juristas envolvidos no estudo e a que eles próprios fizeram referência também expressa na exposição de motivos - resolução de problemas, deixando de "ver o processo como teoria descomprometida de sua natureza fundamental de método de resolução de conflitos, por meio do qual se realizam valores constitucionais. ${ }^{242}$

\footnotetext{
239 Ibidem.

240 Andamento do projeto verificado em 22/12/2010 no site www.camara.gov.br

241 A Exposição de Motivos do Anteprojeto, subscrita pela Comissão de juristas responsáveis pelo documento (composta pelos Ministro Luiz Fux, do Superior Tribunal de Justiça, a Doutora Teresa Wambier e os Doutores Adroaldo Fabrício, Benedito Pereira Filho, Bruno Dantas, Elpídio Nunes, Humberto Teodoro Júnior, Jansen Almeida, José Miguel Medina, José Roberto Bedaque, Marcus Vinícius Coelho e Paulo Cezar Carneiro) parte inicialmente da constatação de que sistema processual que não seja apto à proporcionar à sociedade o reconhecimento e realização dos direitos não se coaduna com as garantias do Estado Democrático de Direito.

${ }^{242}$ A comissão neste aspecto invoca lição de Sálvio de Figueiredo Teixeira que a propósito do advento da Constituição da República do Brasil de 1988 afirmara que "nenhum texto constitucional valorizou tanto a "Justiça" tomada aqui a palavra não no seu conceito clássico de "vontade constante e perpétua de dar a cada um o que é seu", mas como conjunto de instituições voltadas para a realização da paz social" ( aprimoramento do
} 
O projeto do novo Código de Processo civil, se aprovado, passará a conter em seu bojo princípios processuais constitucionais ${ }^{243}$, além da positivação de regras que também possibilitem a concreção desses mais altos valores a exemplo de regras relativas ao contraditório.

Da leitura da exposição de motivos percebe-se a nítida e positiva preocupação dos autores do projeto com a concretização dos princípios e valores constitucionais através do método de resolução de conflitos chamado processo traçando esses idealizadores cinco objetivos: "1) estabelecer expressa e implicitamente verdadeira sintonia fina com a Constituição Federal; 2) criar condições para que o juiz possa proferir decisão de forma mais rente à realidade fática subjacente à causa; 3) simplificar, resolvendo problemas e reduzindo a complexidade de subsistemas, como, por exemplo, o recursal; 4) dar todo o rendimento possível a cada processo em si mesmo considerado; e, 5) finalmente, sendo talvez este último objetivo parcialmente alcançado pela realização daqueles mencionados antes, imprimir maior grau de organicidade ao sistema, dando-lhe, assim, mais coesão". (grifo meu).

Interessa particularmente ao objeto deste estudo a pretensão veiculada no objetivo de número dois da comissão, qual seja, possibilitar ao julgador uma decisão mais aderente aos fatos relativos ao feito o que se revela especialmente nos seguintes dispositivos abaixo transcritos:

Art. 261. O ônus da prova, ressalvados os poderes do juiz, incumbe:

I - ao autor, quanto ao fato constitutivo do seu direito;

II - ao réu, quanto à existência de fato impeditivo, modificativo ou extintivo do direito do autor.

processo civil como garantia da cidadania.In: FIGUEIREDO TEIXEIRA, Sálvio. As garantias do cidadão na Justiça. São Paulo: Saraiva, 1993. p.80

${ }^{243}$ Artigos $1^{\circ}$ ao $11^{\circ}$ do Anteprojeto situados no Título I - Princípios e garantias, normas processuais, jurisdição e ação em seu Capítulo I - dos princípios e das garantias fundamentais do processo civil, contendo a parte geral os princípios e garantias fundamentais do processo civil. 
Art. 262. Considerando as circunstâncias da causa e as peculiaridades do fato a ser provado, o juiz poderá, em decisão fundamentada, observado o contraditório, distribuir de modo diverso o ônus da prova, impondo-o à parte que estiver em melhores condições de produzi-la.

$\$ 1^{o}$ Sempre que o juiz distribuir o ônus da prova de modo diverso do disposto no art. 261, deverá dar à parte oportunidade para o desempenho adequado do ônus que lhe foi atribuído.

$\S 2^{o}$ A inversão do ônus da prova, determinada expressamente por decisão judicial, não implica alteração das regras referentes aos encargos da respectiva produção.

Da dicção do caput do artigo 262 percebe-se a adoção expressa pelo legislador da teoria dinâmica do ônus da prova, entretanto de maneira supletiva à regra prevista no art.261 do mesmo diploma e que reproduz, parcialmente, a regra estática do ônus da prova (art.333 do Código Processual Civil em vigor). Diga-se parcialmente, pois o próprio projeto ressalva os poderes instrutórios do juiz a fim de que não pairem quaisquer dúvidas quanto à possibilidade de iniciativas probatórias do magistrado sem que com isso haja malferimento à sua condição de imparcialidade no processo. Isto porque não só os poderes instrutórios do juiz foram valorizados, mas sim o conjunto de prerrogativas da magistratura exercíveis no processo deram um salto qualitivo em direção ao escopo de um processo mais célere, mais justo e mais rente ao direito material.

O projeto não está imune a críticas que o desqualificam, mas vislumbrando aspectos muito positivos em contraposição àquelas que tem sido formuladas e não lhes atribuindo um caráter de universalidade, Guilherme Guimarães Feliciano afirma que as contrariedades manifestadas "dizem com aquilo que tende a representar justamente o maior sopro de novidade desse novo regramento: a subordinação do procedimento à necessidade do direito material (art.107, V - a que equivale, p.ex.o <princípio da adequação formal> artigo $265^{\circ}$ - A do Código de Processo Civil português), caminhando para um conceito de justa jurisdição, i.e., de jurisdição como estrita função de tutela de direitos materiais. Para esse fim, incrementam-se os poderes diretivos e instrutórios do juiz (v., e.g., os artigos $151, \S 1^{\circ}$ e 285,III, do anteprojeto), aproximando-se do chamado "modelo de Sttutgart" - e, por essa via, 
consubstanciando um importante passo qualitativo no sistema processual brasileiro, a romper com cera visão formalista, mcanicista e positivisa do processo que ainda impregnava o próprio Código BUZAID.’'(g.n.) 244

O projeto confere aos juízes uma maior liberdade de convicção para instruir e julgar tendo por fundamento a base axiológica das normas e princípios da Constituição. Essa liberdade se reflete com todo seu explendor justamente no dispositivo em comento (art.262) na medida em que, não reproduzindo o projeto as disposições do Código de Defesa do Consumidor, não atrela a valoração do juiz quando da atribuição do ônus da prova a quaisquer condições subjetivas dos litigantes, a exemplo de hipossuficiência ou a critérios de verossimilhança.

Registre-se, ainda que óbvio, que o projeto não ignorou as regras clássicas de distribuição do ônus da prova repetindo-as no art. 261 acima transcrito, mas aperfeiçoou-as ao relativizá-las permitindo sua flexibilização para melhor adequação ao caso concreto. E essa liberdade vem acompanhada da responsabilidade de observância às garantias constitucionais na medida em que o projeto exige a cientificação da parte (paragráfo primeiro do art.262) e a decisão judicial expressa e fundamenada (parágrafo segundo do mesmo dispostivo).

\section{Jurisprudência}

A jurisprudência brasileira é que de fato vem demonstrando a adoção da teoria da carga probatória dinâmica em várias matérias, em que pese observar-se que o maior campo de aplicação se dá nas questões de responsabilidade civil do profissional liberal, em especial o médico. Fredie Didier igualmente leciona nesse sentido. ${ }^{245}$

\footnotetext{
${ }^{244}$ FELICIANO, Guilherme Guimarães. Um olhar sobre o novo código de processo civil (PLS n.166/2010) na perspectiva das prerrogativas da magistratura nacional (especialmente na Justiça do Trabalho). Cadernos da AMATRA IV. 14 . Caderno de Estudos sobre Processo e Direito do Trabalho. Porto Alegre, no. 14 - Novembro 2010, pp.57-58

245 DIDIER JR, Fredie; BRAGA, Paula Sarno; OLIVEIRA, Rafael. Curso de Direito Processual Civil vol.2. Salvador: Juspodivm, 2009, p.96
} 
Verdadeiramente o ingresso da teoria dinâmica do ônus da prova no direito nacional tem se dado primordialmente via jurisprudência ${ }^{246}$ e não pretendendo esgotar o estudo da questão no âmbito jurisprudencial, passo a apontar alguns casos de recepção, pela jurisprudência dessa nova teoria conforme a matéria, ressaltando, entretanto, que os Tribunais do Estado do Rio Grande do Sul vêm se destacando no reconhecimento da dinâmica do ônus da prova. Nada obstante até mesmo o Superior Tribunal de Justiça já acolheu a teoria em alguns julgados e é de sua origem o Acórdão considerado vanguarda nessa matéria.

Assim, cumpre inicialmente e numa posição de destaque fazer referência ao julgado emblemático do Superior Tribunal de Justiça, de relatoria do Ministro Ruy Rosado de Aguiar que em 1996 já reconhecia a teoria da dinamização do ônus probatório, a saber, ${ }^{247} \cdot$ :

"Ementa: Responsabilidade civil. Médico. Clínica. Culpa. Prova.

1. Não viola regra sobre a prova o acordão que, alem de aceitar implicitamente o principio da carga dinâmica da prova, examina o conjunto probatório e conclui pela comprovação da culpa dos réus.

2. Legitimidade passiva da clinica, inicialmente procurada pelo paciente.

3. Juntada de textos científicos determinada de oficio pelo juiz. Regularidade.

4. Responsabilização da clinica e do medico que atendeu o paciente submetido a uma operação cirúrgica da qual resultou a secção da medula.

5. Inexistência de ofensa a lei e divergência não demonstrada.

Recurso especial não conhecido. (g.n.)"

Em manifestação bem mais recente no Superior Tribunal de Justiça ${ }^{248}$, a Ministra Nancy Andrighi em outubro de 2009 entendeu aplicável a teoria da distribuição dinâmica do ônus da prova como regra de julgamento com presunção desfavorável ao réu que

\footnotetext{
${ }^{246}$ CÂMARA, Alexandre Freitas. Doenças Preexistentes e ônus da prova: o Problema da Prova Diabólica e uma possível solução". Revista Dialética de Direito Processual. São Paulo: Dialética, 2005, n.31, p.15

247 REsp 69.309/SC, Rel. Ministro Ruy Rosado de Aguiar, Quarta Turma, julgado em 18/06/1996, DJ D26/08/1996 p. 29688

248 REsp 896435 / PR, Rel. Ministra NANCY ANDRIGHI, Terceira Turma, julgado em 27/10/2009, DJe $09 / 11 / 2009$.
} 
assumiria, com base nesse novo postulado, o risco da impossibilidade de apresentação de documento pertinente ao processo. Segue transcrita a ementa do Recurso Especial:

"EMENTA: Processo civil. Ação discutindo devolução de parcelas pagas a administradora de consórcios. Contrato firmado à época em que os Grupos Volkswagen e Ford operavam conjuntamente, por intermédio da Autolatina. Ação proposta em face de empresa administradora de consórcios Ford. Ausência de juntada, pela autora, do contrato de consórcio e dos recibos quanto aos pagamentos efetuados. Alegação de ilegitimidade passiva pela ré, sob o fundamento de que o grupo de consórcio a que aderiu a autora fora transferido à administradora de consórcios ligada ao Grupo Volkswagen, por ocasião da cisão da Autolatina. Processo extinto, sem resolução de mérito, pelo Tribunal, sob o fundamento de que a exibição de documentos teria de ser promovida mediante ação cautelar, em caráter preparatório, e de que seria indeterminado o pedido formulado em via principal. Reforma da decisão.

- Do ponto de vista eminentemente formal, é do autor o ônus da juntada, na petição inicial, dos documentos que fundamentam sua pretensão. Com a perda do contrato mediante a qual aderiu a consórcio, a autora teria, em princípio, de ajuizar uma ação cautelar preparatória de exibição de documentos para, só depois, se for o caso, ajuizar a ação principal de cobrança das parcelas pagas.

- Numa perspectiva dinâmica do processo, é possível ao juiz admitir a propositura da ação principal sem esses documentos, se formulado pedido incidental para sua exibição.

- A alegação de ilegitimidade, pelo réu, com fundamento em que, após a cisão da Autolatina, o grupo de consórcios a que aderiu a autora passou a ser administrado por empresa ligada ao grupo Volkswagen não influencia o conhecimento do pedido de exibição incidental. A impossibilidade de exibição e a determinação de tal providência por terceiro são medidas passíveis de serem discutidas no âmbito do procedimento incidental (arts. 357 e 360 do CPC).

-Após concluído o procedimento de exibição, duas linhas de possibilidades se abrirão para o juiz. Se o documento tiver sido obtido, ele poderá, analisando-o, verificar: (i) se o contrato foi firmado antes ou depois da vigência do CDC; (ii) quem era a administradora de consórcios contratada; (iii) quem permaneceu responsável pela carteira de clientes com a cisão da Autolatina; (iv) se houve prescrição da pretensão; (v) se há parcelas pagas a serem devolvidas.

- Se o documento não puder ser exibido, por sua inexistência ou extravio, competirá ao juiz decidir por: (i) impor ao autor o ônus da prova quanto à sua existência; (ii) aplicar a inversão determinada no art. $6^{\circ}$, VIII, do CDC, se entender aplicável; (iii)

distribuir, ainda que não se aplique o CDC, de forma dinâmica o ônus da prova, com base no risco, assumido pelo réu, pela impossibilidade de apresentação do documento.

Recurso especial provido.” (g.n.) 
Outros Tribunais de Justiça Estaduais vêm adotando a teoria da distribuição dinâmica do ônus da prova impondo-se registrar o pioneirismo dos magistrados da região sul do país.

O Tribunal de Justiça do Estado de São Paulo proferiu em 23 de outubro de 2008 acórdão extremamente interessante no que tange à adoção da teoria da distribuição dinâmica do ônus da prova, nos autos do Agravo de Instrumento no. 804.013-5/0-00, da Comarca de Caraguatatuba entre partes: agravante PREFEITURA MUNICIPAL DA ESTÂNCIA BALNEARIA DE CARAGUATATUBA sendo agravados ÂNGELO DONDICE NETO E AFONSO JUSTINO DA SILVA REGINA CAPISTRANO, tendo tomado parte no julgado os Desembargadores Lineu Peinado, Renato Nalini e de relatoria do Desembargador Samuel Junior. Cumpre transcrever boa parte da fundamentação do voto que aborda inclusive a doutrina estrangeira no tema:

"Como cediço, o ônus probatório recai diretamente sobre as partes, conforme as regras do artigo 333 do CPC. Assim, ao autor cumpre provar os fatos que embasam sua pretensão e ao réu os fatos obstativos da pretensão contra ele articulada, ou seja, fatos modificativos, extintivos ou impeditivos do direito do autor. Mas esta regra foi erigida à luz de um processo concebido sob a ótica dos direitos privados e da igualdade formal, que não condiz com a realidade de relações de massa e assimétricas, como é o caso das relações de consumo e também das ações civis ambientais. Assim, em princípio, há necessidade de flexibilização das regras, para que possa ser encontrada a verdade real e para que questões formais não superem as de fundo.

Por isso, a luz de moderna orientação doutrinária, que como se verá mais adiante já vem sendo encampada pela jurisprudência, em casos como o presente a produção da prova deve ser carreada à parte que apresente melhores condições de produzi-la, à luz da chamada Teoria das Cargas Probatórias Dinâmicas.

Observe-se que tal teoria não se confunde com a inversão do ônus da prova, tendo em vista que este não é repassado por inteiro à parte contrária, que, apenas, fica incumbida de complementar a prova no interesse da elucidação dos fatos

Para ANTÔNIO JANYR DALL'AGNOL JÚNIOR, (Distribuição Dinâmica dos Ônus Probatórios Revista Jurídica, 137. Porto Alegre, n. 280), a Teoria das Cargas Probatórias Dinâmicas permite "que se imponha ao demandado o ônus de antecipar as despesas necessárias para produção de perícia destinada à prova de fato constitutivo alegado pelo autor", entre outras medidas que também elenca.

A chamada Teoria Dinâmica de Distribuição do Ônus da Prova tem suas raízes fincadas especialmente na Argentina, com a denominação também de Teoria das Cargas Processuais Dinâmicas, tendo sido um de seus precursores o j u r i s t a Jorge W. Peyrano A Teoria está lastrada na simples idéia de que se pode incumbir 
a carga probatória a quem, pelas circunstâncias do caso e sem interessar se é autor ou réu na ação, se encontre em melhor condição para produzi-la.

Aliás, de "lege ferenda" o Anteprojeto do Código Brasileiro de Processos Coletivos, no seu art. 10, § Io, adota integralmente o critério dinâmico, pelo qual a prova dos fatos cabe a quem estiver mais próximo dela e tiver maior facilidade para produzi-la Digna, portanto, é a transcrição do aludido artigo dada a importância da inovação que trará ao ordenamento jurídico brasileiro:

"Art. 10. Provas - São admissíveis em juízo todos os meios de prova, desde que obtidos por meios lícitos, incluindo a prova estatística ou por amostragem.

$\S 1{ }^{\circ}$. Sem prejuízo do disposto no artigo 333 do Código de Processo Civil, o ônus da prova incumbe à parte que detiver conhecimentos técnicos ou informações específicas sobre os fatos, ou maior facilidade em sua demonstração " (grifei)

Além disso, também de "lege ferenda", recente Projeto de Lei (PL 3 015/2008), em tramitação no Congresso Nacional, visa alterar o artigo 333 do CPC, inserindo um parágrafo segundo, com a seguinte redação:

$\S 20$ É facultado ao juiz, diante da complexidade do caso, estabelecer a incumbência do ônus da prova de acordo com o caso concreto"

A jurisprudência, como dito anteriormente, já vem se manifestando pela aplicabilidade da nova Teoria, sendo importante, entre outros, mencionar os seguintes precedentes:

"RESPONSABILIDADE CIVIL. MÉDICO CLÍNICA CULPA PROVA 1 Não viola regra sobre a prova o acórdão que, além de aceitar implicitamente o princípio da carga dinâmica da prova, examina o conjunto probatório e conclui pela comprovação da culpa dos réus. 2 Legitimidade passiva da clínica, inicialmente procurada pelo paciente. 3. J u n t a d a de textos científicos determinada de ofício pelo juiz

Regularidade 4.Responsabilização da clínica e do médico que atendeu o paciente submetido a uma

operação cirúrgica da qual resultou a secção da medula 5 Inexistência de ofensa à lei e divergência

não demonstrada Recurso Especial não conhecido "STJ. REsp 69309 / SC, RECURSO ESPECIAL

1995/0033341-4 Rel(a)/Min. Ruy Rosado de Aguiar. Órgão Julgador* T4 - Quarta Turma. Data do

Julgamento: 18/06/1996 Data da Publicação/Fonte DJ 26.081996 p 29688;

"TRIBUTÁRIO PROCESSUAL CIVIL EXECUÇÃO.FISCAL REDIRECIONAMENTO DA EXECUÇÃO.DISSOLUÇÃO IRREGULAR. POSSIBILIDADE. Em casos de dissolução irregular deve ser aplicado o princípio da carga dinâmica da prova, que estabelece que o ônus probatório deve recair àquele que dispõe dos melhores meios para comprovar determinado fato, independentemente de quem o alegue, e (...) STJ. Ag 706524. Rel(a).: Mm. Teon Albino Zavascki

Data da Publicação: DJ 05.10.2005;

"APELAÇÃO CÍVEL. INDENIZAÇÃO POR DANO MORAL ANÚNCIO INVERÍDICO OFENSIVO À HONRA DA AUTORA VEICULADO NO SITE DA REQUERIDA RESPONSABILIDADE DO PROVEDOR E DO FORNECEDOR DE SERVIÇOS APLICAÇÃO DA TEORIA DA CARGA DINÂMICA DO ÔNUS DA PROVA.VALOR DA INDENIŽAÇÃO ATENÇÃO AO CRITÉRIO PUNITIVO-PEDAGÓGICO AO OFENSOR E COMPENSATÓRIO À VÍTIMA INAPLICABILIDADE AO CASO PELO JUÍZO A QUO DO INSTITUTO NORTEAMERICANO DO PUNITIVE-DAMAGES. 1. Incontroverso o fato de que o anúncio registrado no site "Almas Gêmeas" pertencente à requerida, foi efetuado por terceiro alheio ao processo. 2 - Atuando a ré como provedora de acesso à Internet e não sendo possível a identificação do real responsável pelo conteúdo ofensivo do anúncio, é seu o dever de indenizar pelos danos à personalidade da autora Aplicação da Teoria da Carga Dinâmica da Prova, ou seja, incumbe a quem tem mais condições a prova de fato pertinente ao caso. " 
Apelação Cível N70013361043, Sexta Câmara Cível, Tribunal de Justiça do RS, Relator: Artur Arnildo Ludwig, Julgado em 21/12/2006;

"APELAÇÕES CÍVEIS. AÇÃO DE REVISÃO DE CONTRATO GARANTIDO POR ALIENAÇÃO FIDUCIÁRIA AUSÊNCIA DO CONTRATO OBJETO DA PRETENDIDA REVISÃO. Caso em que o contrato objeto da pretensão revisional não veio aos autos, ônus que cabia à instituição financeira, pela observância ao princípio da carga dinâmica da prova. Inteligência, ainda, do artigo 355 do CPC SENTENÇA DESCONSTITUÍDA DE OFÍCIO. Apelação Cível N ${ }^{\circ} 70017420225$, Décima Quarta Câmara Cível, Tribunal de Justiça do RS, Relator- Isabel de Borba Lucas, Julgado em 07/12/2006";

"ASSISTÊNCIA JUDICIÁRIA GRATUITA.IMPUGNAÇÃO JULGADA PROCEDENTE AUSÊNCIA DE PROVA DA HIPOSSUFÍCIÊNCIA ALUSÃO À GARANTIA CONSTITUCIONAL APLICAÇÃO DA TEORIA DA DISTRIBUIÇÃO DINÂMICA DA PROVA.Mantém-se o decreto judicial que acolhe a impugnação à gratuidade judiciária, quando o

impugnado deixa de comprovar com suficiência sua impossibilidade em atender os ônus do processo e os elementos colacionados aos autos evidenciam a potência financeira dos litigantes A garantia constitucional que assegura o benefício da assistência jurídica integral e gratuita exige, além da simples "afirmação" da pobreza", também a "comprovação" da hipossuficiência de recursos (CF, art. 5o, LXXIV), o que enseja a discricionariedade judicial em sua avaliação Cabe ao requerente, assim, como parte mais habilitada, cumprir a demonstração, em respeito à "teoria da distribuição dinâmica da prova", fornecendo todos os elementos de convicção que persuadam sobre alegada hipossuficiência.APELO DESPROVIDO. Apelação Cível $\mathrm{N}^{\circ}$ 70010284180, Sétima Câmara Cível, Tribunal de Justiça do RS, Relator* José Carlos Teixeira Giorgis, Julgado em 16/03/2005",

"APELAÇÃO CÍVEL COMERCIAL, CIVIL E PROCESSUAL CIVIL. PROTESTO INDEVIDO DE DUPLICATAS. CAUSA DEBENDI INEXISTÊNCIA ÔINUS DA PROVA. DANO MORAL IN RE IPSA. FACTORING. DIREITO DE REGRESSO PROTESTO. DESNECESSIDADE. EXISTÊNCIA DE OUTROS PROTESTOS SENTENÇA ULTRA PETITA. NÃOCARACTERIZAÇÁO JUROS. TERMO INICIAL EXTINÇÃO DA AÇÃO CAUTELAR ANTECIPAÇÃO DE TUTELA. DESCABIMENTO. Não se poderia exigir da sacada a prova da inexistência da relação jurídica,pois trata-se de prova negativa, conhecida também como prova impossível ou prova diabólica Caso de aplicação do princípio da carga dinâmica da prova, o qual informa que o ônus da prova cabe à parte que melhores condições tem de produzi-la. Apelação Cível $\mathrm{N}^{\circ}$ 70006513477, Nona Câmara Cível, Tribunal de Justiça do RS, Relator: Adão Sérgio do Nascimento Cassiano, Julgado em 15/ 12/2004".

E nada impede que tal Teoria, principalmente, em situações como a presente, seja aplicada de ofício pelo Tribunal, ainda que em sede de agravo, já que a destinatária da prova é a própria Justiça. Segundo Dall’Agnol, essa teoria permite

- que se imponha ao demandado o ônus de antecipar as despesas necessárias para a produção de perícia destinada à prova de fato constitutivo alegado pelo autor,

- que se imponha a hospital a prova da regularidade de seu comportamento, pois ele é que deve sempre cuidar de ser preciso nos relatórios, fichas de observação, controle, tratamento, remédios ministrados e tudo o mais que possa ilustrar cada caso;

- que recaia sobre o cirurgião o ônus de esclarecer o juízo sobre os fatos da causa, pois nenhum outro tem como ele os meios para comprovar o que aconteceu na privacidade da sala cirúrgica e sobre os médicos em geral, o ônus de comprovar a regularidade de sua atuação;

- que caiba às instituições bancárias o ônus da produção da prova documental relativa à relação contratual, bem como o ônus de provar a legalidade de suas cláusulas e de sua execução.

Na obra CARGAS PROBATÓRIAS DINÂMICAS, dirigida por Jorge W Peyrano e coordenada por Inês Lepori White ( Rubinzal - Culzoni Editores, Buenos Aires, 
Argentina), Mana Belén Tepesich (fls155), bem ressalta "El juez está obligado a fallar (art 15, Cód Civ), incluso quando de Ias pruebas colectadas no se hayan demonstrado cabalmente los hechos. Ello ES asi a diferencia de Io que ocurra en antiguo proceso formularlo Del Derecho Romano, donde el Juez - jurando que no habia podido formar su convicción - podia eludir ei pronunciamiento mediante el non liquet, es decir, "no Io veo claro" (sibi non liquere). Sabido és que para averiguar La verdad en una contienda, en nuestro actual proceso civil, se vale el magistrado de La pruebas que las partes han suministrado al proceso, y con la finalidad exclusiva de convencerlo de sus respectivas versiones. De ello se infere que frente à la existencia de hechos controvertidos y la ausência de prueba, adquieren relevancia los principios que ordenan la distribuición de lugar de la prueba"

Portanto, se já de início se constata a impossibilidade da autora produzir a prova pericial, porque não tem como pagar as despesas provisórias, impõe-se, sempre que se vislumbrar que a parte contrária pode arcar com a mesma, a aplicação de tal Teoria."

No Tribunal de Justiça do Estado do Paraná a $9^{\text {a }}$ Câmara Cível em decisão monocrática, Processo de Agravo de Instrumento no. 0642518-9, de Relatoria da Desembargadora Rosana Amara Girardi Fachin EM 17/12/2009 (DJ:302) assim se pronunciou:

“A respeitável decisão agravada fundamenta na verossimilhança das alegações trazidas na inicial, porque, o fato alegado pelo Autor - a invalidez - é incontroverso, tanto que a seguradora pagou a indenização administrativamente, amparada na versão de que a invalidez foi parcial. O entendimento adotado pelo Magistrado, outrossim, está alinhado com teoria da distribuição dinâmica das cargas probatórias, cujo fito é atribuir o ônus probatório a quem, pelas circunstâncias do caso concreto, se encontre em melhores condições para produzir a prova, visando a garantir maior efetividade à tutela jurisdicional. Nesse sentido, precisas são as lições de Antonio Janyr Dall'Agnol Junior, referindo-se ao jurista argentino Jorge W. Peyrano, precursor da tese: "A tese, aparentemente singela, rompe com a concepção 'demasiado rígida y apriorística' da doutrina clássica, que adotava uma 'visíon exclusivamente estática' da questão relativa a regras de distribuição do ônus da prova. A solução alvitrada tem em vista o processo em sua concreta realidade, ignorando por completo a posição nele da parte (se autora ou ré) a espécie de fato (se constitutivo, extintivo, modificativo, impeditivo). Há de demonstrar o fato, pouco revela se alegado pela parte contrária, aquele que se encontra em melhores condições de fazê-lo"2. Assim, não há estabelecimento prévio e abstrato do encargo, vez que, quanto ao onus probandi, é irrelevante a posição das partes no processo. Pode-se dizer, portanto, que o ônus probatório é compartilhado pelas partes, não bastando ao demandado postura meramente passiva, devendo atuar em benefício do processo, com fulcro nos princípios da boa-fé. A incumbência da comprovação deve ser determinada pelo Juiz, a partir da análise das circunstâncias particulares do caso concreto, tendo em 
vista a natureza do fato a provar, retirando-se o peso da carga da prova de quem se encontra em evidente debilidade de suporta tal ônus. Ressalta-se que a idéia de abrandamento da visão estática da distribuição do ônus da prova não é nova, mesmo em nosso ordenamento, como se verifica na obra de Moacyr Amaral Santos: "a obrigação da prova deve ser, em cada caso individual, imposta àquela das partes que a pode desempenhar com menos incômodo, isto é, menos detalhes, vexames, despesas, etc" 3 . Considerando as premissas postas, percebe- se que a adoção desse ideário no caso em comento representa a garantia da igualdade processual entre os litigantes, conforme preconiza o artigo 125, I, do CPC, permitindo-se, por meio de um amplo contraditório, a chegada, ou ao menos a aproximação, à verdade real, situação que atende aos postulados do devido processo legal. No que atine ao pagamento dos honorários periciais, como bem salientou o magistrado singular, a Agravante não está obrigada ao pagamento dos custos, mas deve estar ciente de que a não realização das provas, em virtude do não pagamento valores para tanto necessários, virá em seu próprio prejuízo, eis que, na ausência de demonstração em contrário, prevalecerão as alegações do Agravado. III. Por tais motivos, com fulcro no art. 557, caput, do CPC, nego seguimento ao presente Agravo de Instrumento, para o fim de manter a decisão agravada. Intimem-se. Curitiba, 15 de dezembro de 2009. ROSANA AMARA GIRARDI FACHIN Desembargadora Relatora -- 1 Fls. 49v. -TJ. -- 2 DALL'AGNOL Jr., Antonio Janyr. Distribuição Dinâmica dos Ônus Probatórios. Revista dos Tribunais, vol. 788. Revista dos Tribunais: São Paulo, junho/2001. -- 3 SANTOS, Moacyr Amaral. Prova judiciária no cível e comercial, $5^{a}$ edição. São Paulo: Saraiva, 1983.” (g.n).

Outra decisão quanto à aplicabilidade da teoria da distribuição dinâmica do ônus da prova se expressa no Acórdão da apelação cível no 70023210651 - 9a Câmara Cível Pelotas, de relatoria do Desembargador Odone Sanguiné, proferido em 18 de junho de 2008, a seguir transcrito em parte:

"Destarte, diante da verossimilhança acima demonstrada, cumpre referir que se está diante de um caso que enseja a aplicação da distribuição de dinâmica do ônus da prova. Tal regra de distribuição do ônus probatório tem sido largamente aplicada quando as circunstâncias do caso acarretam a dificuldade, ou até impossibilidade, para a produção da prova por parte de quem possui tal ônus segundo a regra contida no art. 333 do CPC. A este respeito, bem leciona Antonio Janyr Dall'Agnol Junior, (Distribuição dinâmica dos ônus probatórios, Revista dos Tribunais, São Paulo, 788, 92-107, jun./2001), verbis: "Pela teoria da distribuição dinâmica dos ônus probatórios, portanto, a) inaceitável o estabelecimento prévio e abstrato do encargo; b) ignorável é a posição da parte no processo; c) e desconsiderável se exibe a distinção já tradicional entre fatos constitutivos, extintivos, etc. Releva, isto sim, a) o caso em sua concretude e b) a 'natureza' do fato a provar - imputando-se o encargo àquela das partes que, pelas circunstâncias reais, se encontra em melhor condição de fazê-lo. "Como ensina Arazi, asseverando que o critério tem sido aplicado 'com frequência' pela jurisprudência, 'é importante que o Juiz valore as circunstâncias particulares de 
cada caso, apreciando quem se encontrava em melhores condições para comprovar o fato controvertido, assim como as razões pelas quais quem tinha o ônus de provar não produziu a prova'. "Mais adiante, o mesmo jurista registra que se denominou 'dinâmica' a esta concepção 'por sua mobilidade para adaptar-se aos casos particulares, a fim de opô-la a uma idéia estática igual para todos os supostos sem atender às circunstâncias especiais'. O que ocorre, pelo visto, é uma flexibilização da doutrina tradicional, em homenagem ao princípio da efetividade da tutela jurisdicional, na medida em que essa objetiva, sem dúvida, garantir o direito a quem realmente o titule". Assim, quando a aplicação dos contornos tradicionais do ônus probatório na legislação processual civil não socorre a formação de um juízo de convencimento sobre a formação da culpa do médico, ou da insuficiência estrutural do hospital, a teoria da carga dinâmica da prova, importada da Alemanha e da Argentina, prevê a possibilidade de atribuir ao médico, ou ao Hospital, a prova da sua não-culpa, isto é, não incumbe à vítima demonstrar a imperícia, a imprudência ou a negligência do profissional, mas a este, diante das peculiaridades casuísticas, a sua diligência e o emprego da técnica e da utilização da estrutura aprovadas pela literatura médica. Destarte, a aplicação de dita teoria não corresponde a uma inversão do ônus da prova, mas avaliação sobre o ônus que competia a cada uma das partes. Diante de tal contexto, concluo que houve erro da equipe médica do Hospital-réu, a qual foi negligente ao não ter adotado, diante das circunstâncias do caso concreto, o procedimento de cesariana."

De fato denota-se da pesquisa prévia que foi realizada que a teoria da distribuição dinâmica do ônus da prova não é estranha à jurisprudência nacional. Pelo contrário, seu campo de aplicação vem se alargando inclusive na esfera trabalhista como se verá no último capítulo. 


\section{CAPÍTULO IV - DISTRIBUIÇÃO DINÂMICA DO ÔNUS DA PROVA COMO TÉCNICA PROCESSUAL DE EFETIVIDADE DO DIREITO DO TRABALHO}

\section{Questões introdutórias}

O que se tem hoje no processo do trabalho como regra de ônus da prova? A par do já estudado art.818 da CLT em capítulo precedente, boa parte dos doutrinadores e intérpretes partem, a priori do arcabouço processual civil explicitado no art.333 do CPC, como regra suplementar à do art.818 da CLT, insistindo por vezes num posicionamento mais dogmático.

Justo, referir, que há de fato uma maior relativização dessas bases pela jurisprudência, existindo inclusive inúmeras decisões de primeira e segunda instâncias bem assim súmulas do Tribunal Superior do Trabalho que, conquanto não apontem explicitamente, consideram a maior aptidão da prova para atribuição do encargo respectivo pela sua produção. ${ }^{249}$ Exemplo atual consubstancia-se na súmula de número 338 do Tribunal Superior do Trabalho ${ }^{250}$ que imputa ao réu carrear ao processo os registros de ponto e, se invariáveis reputa-lhe o ônus da prova da jornada de trabalho, anteriormente atribuído ao empregado. Não fosse latente no direito processual do trabalho o desequilíbrio probatório das partes na medida em que é o empregador que tem a exclusividade ou o maior acesso à documentação do contrato de trabalho, a própria existência daquela súmula demonstra reconhecimento dessa situação díspar. Nem se fale também nas melhores condições de realização de prova oral vez

\footnotetext{
${ }^{249}$ Edmar Souza Salgado afirma em sua dissertação que o crescimento do número de exceções à aplicação do art.818 da CLT e art.333 do CPC vêm ganhando espaço nos processos trabalhistas diante das respostas insatisfatórias a que esses dispositivos conduzem quando se realiza a distribuição do ônus da prova inflexivelmente a parte da premissa da igualdade das partes; fator esse que tem inclusive a aptidão de questionar próprio status de regra geral daqueles dispositivos. In: SALGADO, Edmar Souza Salgado. O princípio da efetividade no processo do trabalho. Tese (Mestrado), Faculdade de Direito, Universidade de São Paulo, 2008, p. 185

${ }^{250}$ A análise da Súmula 338 do Tribunal Superior do Trabalho será aprofundada em item posterior ao final do capítulo.
} 
que no mais das vezes as testemunhas da empresa continuam subordinadas aos seus contratos de trabalho e maiores recursos econômicos para as provas técnicas periciais.

Decisões outras há que, com base no Código de Defesa do Consumidor e a partir do conceito de hipossuficiência, exigem do ator processual mais forte (técnica ou economicamente) que traga aos autos do processo os subsídios probatórios.

Mas, ainda assim, é preciso que o juiz do trabalho não se fixe apenas nas atuais regras do art.333 do CPC, e adote com base em critérios definidos e fundamentos de base constitucional a teoria das cargas probatórias dinâmicas, interpretação mais consentânea, repita-se, com o direito material envolvido. Não haveria sequer óbice calcado na observância de um estrito legalismo vez que o art.818 da Consolidação das Leis do Trabalho como regra aberta que é assim o permitiria. Imprescindível para tanto a evolução da mentalidade dos juízes de modo a se voltarem aos valores subjacentes do direito do trabalho e dar resposta às necessidades da população trabalhadora.

O dia a dia da prática judicial trabalhista tem revelado a existência de limitações não legítimas à garantia constitucional de ação. São os chamados fatores perversos a que faz menção Cândido Dinamarco ${ }^{251}$ e que residem justamente seja em imperfeições processuais e também na realidade sócio-econômica e cultural da própria sociedade.

De fato no acesso à justiça do trabalho o trabalhador por vezes fica refém de obstáculos seja de ordem econômica, organizacional ou procedimental. Aqueles primeiros residem na constatação da pobreza notória de um dos atores na relação processual trabalhista

\footnotetext{
${ }^{251}$ De fato, com apoio inclusive na doutrina de Augusto Mario Morello, reconhece o autor a existência de limitações legítimas à universalização da tutela jurisdicional mas que são ditadas pela Constituição e pela lei e percebe a existência de barreiras ilegítimas, impedindo que o sistema processual civil cumpra a sua função de pacificação e realização de justiça. São os "fatores advindos das imperfeições da própria lei processual e outros fatores, igualmente perversos, residentes na realidade política, sócio-econômica e cultural da sociedade à qual o processo se destina a servir. Para o aperfeiçoamento do sistema é indispensável identificar essas barreiras internas e externas ao sistema (Augusto Mario Morello) e procurar afastá-las na medida do que realisticamente for havido por possível) DINAMARCO, Cândido Rangel. Instituições de Direito Processual Civil.Vol.1,São Paulo: Ed. Malheiros, 2003., p.112.
} 
(o trabalhador) e na tentativa de superar este tipo de barreira alguns mecanismos já foram previstos na legislação processual trabalhista a exemplo do "jus postulandi", assistência sindical, justiça gratuita, dentre outros. Os obstáculos do segundo tipo dizem respeito à preocupação com a adaptação de instrumentos processuais a novas espécies de demandas em especial coletivas as quais se identificam em muito com os direitos sociais dos trabalhadores cuja defesa, quando coletivizada, ganha em força. Sob este aspecto o próprio instituto da substituição sindical dos trabalhadores pelas entidades sindicais é um exemplo da superação de óbices organizações em prol da efetividade. ${ }^{252}$

Há ainda uma terceira ordem de obstáculos, os procedimentais. Como bem aponta Souto Maior, "o direito processual do trabalho desde a sua concepção vem se preocupando em se constituir um processo mais humano e menos burocratizado. Há de se reconhecer, portanto, que o procedimento trabalhista possui características especiais, que o aproximam bastante do desiderato da terceira onda do acesso à justiça muito embora possa ser melhorado". 253

Com efeito, a demanda trabalhista, enquanto processo judicial como qualquer outro, representa a busca de respostas a uma angústia humana. Assim, o processo trata da vida humana na sua multidiversidade e este conflito de direito material se interliga com o próprio direito processual que o atende, não podendo dele se dissociar.

Neste capítulo será especialmente abordada a distribuição dinâmica do ônus da prova aplicada ao processo do trabalho como medida necessária da superação da técnica estática da distribuição do ônus da prova notoriamente em razão da aplicação do princípio da isonomia substancial no processo do trabalho que tem um toque especial do direito material que tutela. Superação esta imprescindível para o alcance dos escopos do processo trabalhista contemporâneo, em especial o objetivo da realização da justiça.

\footnotetext{
${ }^{252}$ SOUTO MAIOR, Jorge Luiz.Direito Processual do Trabalho. Efetividade, Acesso à Justiça e Procedimento oral. São Paulo: LTr, 1999, pp.129-146

${ }^{253}$ Idem.Ibidem.p. 146
} 
Ressalte-se que a adoção da teoria da carga probatória dinâmica demanda um juízo crítico subjetivo, mais ligado aos valores sociais. Esses valores também são os valores de cada indivíduo e diferentes em todos eles. Somente o juiz com as suas potencialidades desenvolvidas poderá com maior desenvoltura aprimorar tanto seu lado criativo, como intuir sobre cada ator do processo qual deles naquele momento terá maiores condições de provar os fatos relatados na causa e daquela exigirá esse encargo.

Nesse sentido Coltro invoca o pensamento de Erlich que asseverou “constituir-se a personalidade do juiz a única garantia de Justiça". Destaca ainda o autor que o juiz "terá que ser um bom homem para ser um bom juiz, de forma a que possa humanizar a Justiça, dela afastando a frieza, impessoalidade e desinteresse que alguns entendem serem suas características, principalmente quando se tem em conta que cada caso submetido a juízo deve ser tido como um caso especial" 254

Com efeito, o juiz quando limitado a uma parte suas potencialidades dará somente maior relevância à formalidade, ao positivismo, não sendo capaz de se descolar, pôrse no lugar do outro (parte do processo) e assim restando impossibilitado de descobrir o que há por trás daquele conflito posto em causa.

Válida novamente a advertência de Coltro no sentido de que "é mais com a intuição do que com o raciocínio que se perscruta um pensamento e se aprecia um individuo ou uma situação determinada". Continua o autor referindo que "o fato é que Jung já apontar a sua importância (da intuição) como auxiliar dos juízes, indicando-a mesmo como o único guia em situações para as quais não existam conceitos já firmados ou valores antes estabelecidos, situando-se ela como 'um tipo de percepção que não passa exatamente pelos sentidos; registrase ao nível do inconsciente.", 255

254 COLTRO, Antônio Carlos Mathias. A atividade judicial e a realização do direito. Revista da ESMESE, no. 05 , 2003. pp. 196 e 205 , respectivamente

${ }^{255}$ Ibidem. p. 190 
A aplicação de teoria da carga dinâmica da prova demanda, antes de mais nada, essa abertura ao novo, seguida da necessidade do desenvolvimento em cada julgador dessas potencialidades aptas a possibilitar sua compreensão de cada caso concreto, cada situação da vida alheia; situações nas quais fatalmente terá que se colocar, ainda que abstratamente, para "sentir", "intuir" e julgar. Situações essas às quais não está e nem pode estar imune o juiz do trabalho a quem não é permitido o medo de ousar eis que à sua frente está um trabalhador à espera ainda que não possa esperar ${ }^{256}$.

A mudança de paradigma será possível especialmente por conta do reconhecimento da atividade criadora do juiz que exigirá, nas palavras de Eugênio Facchini Neto maior aderência do magistrado aos valores sociais e seu maior entrosamento na vida da comunidade $^{257}$.

Defende-se, portanto, nesse capítulo final a teoria dinâmica da distribuição do ônus da prova como técnica processual apta à promoção da efetividade do processo do trabalho por meio da atribuição do encargo probatório especialmente focada na realização de um direito material especialmente tutelado pela Constituição da República e ainda pautada nos próprios princípios do Direito do Trabalho. Também serão identificados de casos julgados com a utilização da técnica pelos juízes do trabalho, os seus campos de aplicação e alguns aspectos procedimentais de utilização do método.

Finalizar-se-á o capítulo com reflexões acerca da distribuição do ônus da prova por meio da técnica dinâmica do ônus da prova sem descuidar do necessário estabelecimento de parâmetros para manuseio da teoria de modo a conformar a nova técnica com os ditames constitucionais do procedimento probatório.

\footnotetext{
${ }^{256}$ VIANA, Márcio Túlio. Critérios para a inversão do ônus da prova no processo trabalhista. LTr: revista legislação do trabalho, São Paulo, v. 58, n. 10, out/1994.p.1218

${ }^{257}$ FACCHINI NETO, Eugênio. "E o Juiz não é só de Direito...". In: Zimerman, David, Coltro, Antônio Carlos Coltro (Org.). Aspectos Psicológicos na Prática Jurídica. Campinas: Editora Millennium, 2002.
} 


\section{Processo do trabalho, efetividade e técnica processual}

Como já visto no primeiro capítulo o Estado Brasileiro por meio da Constituição da República prevê expressamente o acesso à justiça e numa nova ordem de pensamento o constituinte redimensionou essa garantia adequando-a aos princípios de celeridade, economia processual, efetividade e eficácia. E do primado do acesso à justiça deriva o direito à tutela efetiva que é desafiado quando se nega ou obstaculiza gravemente o acesso à jurisdição inclusive na questão da equitativa distribuição dos ônus probatórios.

Direito a tutela jurisdicional efetiva é um direito de conteúdo complexo direito de acesso aos tribunais, direito a sentença fundada em direito congruente, efetividade da decisão, direito recursal. E, considerada uma das funções precípuas do Estado Democrático de Direito que é proporcionar aos indivíduos seu bem-estar, o próprio direito positivo oferece os meios para alcançá-la, dentre eles o reconhecimento da inafastabilidade da prestação jurisdicional, que atuando por intermédio de um poder próprio age na solução dos conflitos com a utilização do instrumento estatal (processo) para a aplicação do direito material em disputa.

O conceito atribuído a uma prestação jurisdicional eficaz está relacionado à celeridade e economia processual, à realização de justiça, a um julgamento equânime e íntegro, a segurança dos direitos individuais e sociais e a todos os institutos que possam de alguma forma colaborar com a manutenção da paz social. ${ }^{258}$ 258 A propósito dos princípios da economia processual e da instrumentalidade das formas que dão a nota da
evolução do direito processual afirmam Antônio Carlos de Araújo Cintra, Ada Pellegrini Grinover e Cândido
Rangel Dinamarco: "O processualista moderno sabe que, pelo aspecto técnico-dogmático, a sua ciência já atingiu
níveis muito expressivos de desenvolvimento, mas o sistema continua falho na sua missão de produzir justiça
entre os membros da sociedade. É preciso agora deslocar o ponto-de-vista e passar a ver o processo a partir de um
ângulo externo, isto é, examiná-lo nos seus resultados práticos. Como tem sido dito, já não basta encarar o
sistema do ponto-de-vista dos produtores do serviço processual (juízes, advogados, promotores de justiça): é
preciso levar em conta o modo como os seus resultados chegam aos consumidores desse serviço, ou seja, à
população destinatária. (...) a efetividade do processo como meio de acesso à justiça depende menos das reformas
legislativas (importantes embora), do que da postura mental dos operadores do sistema (juízes, advogados,
promotores de justiça). É indispensável a consciência de que o processo não é mero instrumento técnico a serviço
da ordem jurídica, mas, acima disso, um poderoso instrumento ético destinado a servir à sociedade e ao Estado.
(...) A mudança de mentalidade em relação ao processo é uma necessidade, para que ele possa efetivamente
aproximar-se dos legítimos objetivos que justificam a sua própria existência. CINTRA, Antonio Carlos; 
Os direitos fundamentais dos trabalhadores enquanto não manifestados na prática são apenas palavras escritas na Constituição da República e na legislação ordinária. Esses direitos sociais são reconhecidos na sua essência e tal a sua importância e magnitude que foram sendo positivados em Declarações de Direitos internacionais e na grande maioria das constituições do mundo ocidental. ${ }^{259}$

Essa condição "a priori” abstrata confere-lhes a sua essência, porém não significa necessariamente sua existência, pois "o direito não é (não é direito) sem se manifestar na prática e como prática. Não temos direito só porque pensamos a essência jurídica ou a juridicidade, ou porque construímos um sistema de normatividade jurídica teremos quando muito a possibilidade (ideal) do jurídico e nada mais. Só o cumprimento histórico-concreto, naquele modo de ser que é a vigência e que lhe permite afirmar-se como efectiva dimensão da prática humano-social, transforma a juridicidade em direito" 260

Como bem adverte Jorge Souto Maior ao tratar desse tema da efetividade:

"Esse é um debate que não se pode limitar ao campo das ideias. Como se trata da busca de efetividade, obviamente, esta pressupõe uma atuação prática. Nesse sentido, o estudo em prol da efetividade do processo encontra óbice de aplicabilidade, pois muitas das novidades almejadas somente podem ser alcançadas com alteração legislativa, que se reflete em uma atuação política que se encontra, normalmente, fora do alcance de doutrinadores e aplicadores do direito.

Entretanto, tal aspecto não diminui a importância de um estudo dessa natureza, primeiro porque não é raro que estudos doutrinários acabem influenciando o legislador e, segundo, porque pode auxiliar decisivamente na aplicação de regras processuais chegando-se a uma interpretação evolutiva, prescindindo até mesmo da alteração legislativa." ${ }^{261}$ (g.n.)

GRINOVER, Ada Pellegrini; DINAMARCO, Cândido Rangel. Teoria Geral do Processo. São Paulo: Malheiros, 1995.pp.43-45 (g.n.)

${ }^{259}$ Para uma compreensão da positivação dos direitos fundamentais nos mais variados diplomas internacionais veja-se COMPARATO, Fábio Konder. A afirmação história dos direitos humanos. São Paulo:Saraiva, 2005.

${ }^{260}$ CASTANHEIRA NEVES, apud OLIVEIRA, Carlos Alberto Alvaro de. Efetividade e tutela jurisdicional (Ensaio destinado a livro em homenagem a Egaz Dirceu Moniz de Aragão) disponível no site do autor: http://www.alvarodeoliveira.com.br/home/artigos_open.php?funcao=abrir\&id_artigo=9. Último acesso em $10 / 12 / 2010$

${ }^{261}$ SOUTO MAIOR, Jorge Luiz. A efetividade do processo. In: CORREIA, Marcus Orione Gonçalves (org.). Curso de direito do trabalho: vol. 4 - Direito processual do trabalho. São Paulo: LTr, 2009. p.46. O autor, com tal afirmação, parecia antever a questão vez que a prática da jurisprudência em especial relativa à responsabilidade 
A dimensão existencial do direito material transplantado para a perspectiva processual relaciona-se intrinsecamente com a questão da efetividade processual seja sob o prisma da celeridade (o tempo de concretização do direito violado através do instrumento processual) seja sob a vertente do próprio conteúdo da decisão judicial (este mais se realinha com o ideal de justiça do caso concreto). ${ }^{262}$

Desta forma o direito do trabalho só é direito em sua existência plena quando possível sua efetivação (em tempo oportuno, com observância do devido processo legal e aplicado com justiça). Registre-se que não chegaremos aqui a realizar uma abordagem exaustiva da matéria da efetividade posto que isso nos levaria a questionamentos próprios até mesmo das fases finais de um procedimento de execução cuja nota atual é justamente a garantia plena do direito reconhecido (e não só prometido) na sentença.

O ambiente jurídico contemporâneo encontra-se propício à recepção de idéias e técnicas que valorizem esse ideário de efetividade vez que a própria concepção do liberalismo que avalizou na sua expressão processual o positivismo privatístico veio observando um notável declínio ao longo do próprio século XX essencialmente após o advento do Estado de Direito Democrático que fez emergir um ideal mais social e isso se expressou também no constitucionalismo social. Este último passou então a revelar os desejos e valores das sociedades democráticas a impregnar, via de conseqüência, o processo com um caráter público próprio da monopolização da justiça nesse Estado democrático.

De fato as preocupações garantísticas que predominaram na seara processual por volta desse mesmo século XX levaram os estudiosos do processo a uma exacerbada preocupação com os valores do contraditório e do due processo law, que passaram a ser considerados verdadeiros dogmas levando ao formalismo excessivo, inclusive exigindo exigir normas e regras técnicas processuais consideradas extremadas e reveladoras dos ideais

civil e questões coletivas, bem assim o que a doutrina nacional já vinha estudando talvez tenham levado à previsão do ônus dinâmico da prova no projeto do novo código de processo civil brasileiro.

${ }^{262}$ OLIVEIRA, Carlos Alberto Álvaro de. Ob.cit. Efetividade e tutela jurisdicional... 
nelas arraigados. Esses dados provocaram um sistema de morosidade na justiça por vezes não sensível ao próprio conflito humano; situação que foi denunciada especialmente a partir da obra de Mauro Cappelletti e sua impressionante percepção da grandeza do significado do acesso à justiça como valor máximo que expressa no sistema no direito processual constitucional. $^{263}$

Na perspectiva do acesso à justiça após a mudança de paradigmas passou-se a dar evidência às reclamações por um processo verdadeiramente ágil e capaz de eliminar conflitos com justiça. Em sendo assim reconhece-se que o princípio da efetividade no plano processual promove a superação de modelos ultrapassados não aptos à solução de situações lesivas ao direito material envolvido, em prol de uma mais eficaz e rápida realização do direito material.

Efetividade significa ainda uma melhor organização do processo e o que mais nos interessa uma mais perfeita instrumentalização deste, inclusive concebendo novas técnicas para realização do direito material até porque o processo só é reconhecido como efetivo quando propicia o acesso à ordem jurídica justa. Desta forma permite-se ao indivíduo que através desse instrumento obtenha a satisfação de sua pretensão de forma mais próxima senão igual ao status quo ante como se seu direito material houvesse sido respeitado e cumprido voluntariamente pelo devedor. ${ }^{264}$

Contemporaneamente não há como negar a interdependência entre o direito material e o instrumento processual que o concretiza. Assim quando se pensa no direito à tutela judicial efetiva, tal direito deve ser compreendido, concebido e adequado às especificidades e necessidades do direito substancial envolvido, ou em outras palavras, a tutela

\footnotetext{
${ }^{263}$ DINAMARCO, Candido Rangel. Nova era do processo civil. São Paulo: Malheiros, 2007, p.21

${ }^{264}$ José Carlos Bedaque neste ponto é enfático quanto à necessidade do juiz assumir efetiva posição de condutor do processo, com ampla participação no contraditório e utilizar técnicas processuais, inclusive através de sua flexibilização para atender aos objetivos desse instrumento. In Direito e Processo. São Paulo: Malheiros, 2001, p. 81
} 
será efetiva quando dentre outras características, se harmonizar com o seu objeto, em especial com os princípios e valores fundamentais. ${ }^{265}$

Daí a necessidade de buscar alternativas para resolução das demandas trabalhistas que aplicando as técnicas existentes não percam de vista também o direito substancial tutelado que procuram efetivar. De fato as situações materiais vão se ampliando e alargando cada vez mais a exemplo do próprio aumento da competência da Justiça do Trabalho após a Emenda Constitucional no. 45/2004 trazendo as situações acidentárias, bem assim novas e velhas relações decorrentes de políticas econômicas do mercado de trabalho como a questão ainda da terceirização precária de serviços. ${ }^{266}$

Há que se ter, portanto, preocupação com o resultado na medida em que o instrumento não é um fim em si mesmo, não obstante a técnica seja necessária. Inquestionável também que as mesmas razões que justificam a proteção do direito material do trabalho também estejam presentes no plano do direito processual do trabalho vez que desigualdades, desequilíbrio, posição de superioridade do empregador transferem-se para o domínio processual, transformando-se em fatores processuais adversos.

Carnelutti já antevia a problemática que causavam as desigualdades na relação processual reconhecendo-as expressamente no campo do marco probatório a partir da

\footnotetext{
265 Novamente e ainda conforme José Carlos Bedaque: "a necessidade que tem o direito material de se valer do processo para alcançar efetividade quando se estabelece o conflito de interesses, bem como a obrigatoriedade para o processo de encontrar para a lide uma justa composição, segundo os padrões do direito positivo, faz com que não se possa pensar juridicamente o direito processual como uma realidade técnica completamente isolada ou autônoma frente ao direito positivo material. É certo que, para fins práticos e pedagógicos, se deve proceder à regulamentação e estudo do Direito Processual fora dos quadros do direito material, mas sem jamais perder de visa a noção de que a existência do direito formal não se justificará, em hipótese alguma, a não ser como instituto prático ligado à necessidade de operar concretamente o direito material nas situações conflituosas". Continua o mesmo autor: "O outro fato de alterações no direito processual reside fora de seu âmbito. Diz respeito ao direito material. Na medida em que se reconhece a necessidade de o instrumento se adequar ao objeto, o processo e seus institutos fundamentais devem ser moldados à luz das necessidades sociais, que fazem surgir novas relações jurídicas" in BEDAQUE, José Roberto. Ob.cit. Direito e Processo. São Paulo: Malheiros, 2001, p.24

${ }^{266}$ Aqui me refiro essencialmente às dificuldades na produção que podem surgir, seja na questão do nexo causal para as doenças e na prova da prestação de serviços através de empresa interposta.
} 
constatação de que a própria desigualdade das partes inclusive não configura exceção e sim a $\operatorname{regra}^{267}$.

Igualmente Estevão Mallet reconhece os empecilhos externos ao processo e que nele se materializam ao asseverar que "as informações que alguns possuem, outros não dominam; o custo da demanda para uns inibe a propositura da ação, enquanto para outros se mostra insignificante; as provas que certos litigantes podem produzir com grande facilidade, outros não têm condições alguma de apresentar em juízo; a demora na solução do litígio, que por vezes beneficia uma das partes, lesa profundamente o direito de outra." 268

Desta forma como contraponto nessa relação jurídica processual na maioria das hipóteses aprioristicamente desigual é que se justificam, por exemplo, as regras para maior facilidade de acesso à justiça pelo trabalhador e ainda outras várias medidas dentre as quais a dinamização do ônus probatório para correção das desigualdades.

Partindo não de uma visão introspectiva do processo, mas sim da perspectiva externa, própria da fase instrumentalista e contemporânea que exige uma análise crítica do intérprete e uma maior preocupação com os resultados temos, afinal, que concluir que o processo do trabalho serve à concretização do direito individual e coletivo do trabalho e deve portanto ser pautado pelos princípios que regem o direito substancial que tutela havendo necessidade de uma identificação ontológica. O processo do trabalho tem verdadeira função social ${ }^{269}$ decorrente de seu caráter público e do interesse social que expressa. Natural

${ }^{267} \mathrm{Na}$ lição do insigne processualista “(...) la desigualdad, por desgracia, constituy, no la excepción, sino la regla. Que uma parte sea más astuta que la outra, más rica más poderosa; que uno de los litigantes sea honesto y otro un canalla; que uno disponga de prubeas y el otro no; que los defensores no sean de igual autoridade y valor; he ahi otras causas de desiquilibrio y outros tanto speligros para la exctitude de la balanza" In CARNELUTTI, Francesco. Lineas Generales de La Reforma del Proceso Civil de Cognición, In Estudios de Derecho Procesal, v.01, Buenos Aires, Ediciones Jurídicas Europa América, 1952, p.97, apud Raquel Heck Mariano da Rocha, A Distribuição do ônus da prova como instrumento garantidor da igualdade das partes no processo civil brasileiro. In Revista Processo e Constituição. Porto Alegre, n.1, dez.2004, p.360

${ }^{268}$ MALLET, Estevão. Discriminação e processo do trabalho. Revista do TST. Rio de Janeiro.V.65, n.1,pp.148159 , out/dezembro/99, p.154

${ }^{269}$ Luiz Eduardo Gunther ao tratar da função social do processo manifesta-se com propriedade no seguinte sentido: "Ora, se há uma efetiva função social do processo, como há na propriedade e no contrato, incumbe ao juiz estar atento para poder garantir, na medida do possível, segurança e previsibilidade ao conviver dos homens. Impõe o reconhecimento dessa função do processo como forma de admitir a realidade da construção de um 
conseqüência dessa função social a necessidade da prestação jurisdicional menos formal e onerosa, mais célere e eficaz, inclusive com predominância da oralidade.

A propósito dessa percepção do processo trabalhista a partir do interesse social que se diferencia do interesse privado assim se manifesta Mario Pasco, calcando-se na doutrina de Eduardo J. Stafforini, "nas contendas de direito privado, afirmam Satafforini e Tissembaum, 'o objeto se concretiza numa órbita de caráter patrimonial que afeta essencialmente o interesse individual das partes; nas contendas do trabalho, em vez, a posição pessoal das partes é deslocada pelo eixo central da mencionada órbita do litígio, pela posição que no mesmo assume o trabalho como noção jurídica social, que atua de uma maneira predominante, tanto na formação das relações contratuais como nas questões ou divergências que dele derivam. O citado deslocamento valorativo que se opera na órbita do conflito limitase a considerar a lesão patrimonial sob a noção diretiva e preponderante do princípio jurídico que informa o conteúdo conceitual sobre o trabalho, como noção predominante tanto de natureza doutrinária como legal. Por esse motivo, os princípios do direito comum cedem sua posição central aos que informa o conteúdo substancial do trabalho, como questão básica e fundamental que deve orientar a solução da contenda" ${ }^{270}$.

Certo é que processo trabalhista é processo de interesses especialmente tutelados, não se lhe podendo aplicar normas e princípios construídos sob o ponto de vista do processo de natureza liberal e privatista a exemplo da tão discutida regra do art.333 do CPC. Pela proposta dinâmica da prova revigora-se o papel das partes e do juiz e, como conseqüência hão de ser alteradas as percepções acerca da prova e de seu ônus e obtido um melhor resultado final, ao menos mais afinado com a realidade possível, diminuindo-se inclusive as incertezas no momento da decisão ${ }^{271}$.

Estado Democrático, que fundamenta essencialmente a atividade jurisdicional”. GUNTHER, Luiz Eduardo. Aspectos principiológicos da execução incidentes no processo do trabalho. In: Execução Trabalhista: Homenagem aos 30 anos da AMATRA IX. Coord. José aparecido dos Santos. São Paulo: LTr, 2008, p.21

270 PASCO, Mario. NASCIMENTO, Amauri Mascaro, 1932- (rev. técn.). Fundamentos do direito processual do trabalho. São Paulo: LTr, 1997, pp.23-24

${ }^{271}$ De fato ao se pretender com a atribuição do ônus dinâmico um revigoramento da atividade probatória das partes que passariam a envidar maiores esforços para munir o processo com os elementos de prova no momento do julgamento por vezes nem seria mais necessário perquirir afinal de quem era o ônus porque haveria elementos suficientes para formação da convicção. 
Ao se pensar na estrutura legal e aqui nos referimos portanto às regras do art.333 do CPC e art.818 da CLT como, por vezes, obstáculos à efetividade do processo, há que se tentar, ao menos, a sua superação de modo a permitir a entrega de respostas satisfatórias aos tutelados na relação processual trabalhista. ${ }^{272}$

Uma forma de superação se daria, portanto, com a utilização da teoria dinâmica do ônus da prova que justamente parte da premissa da insuficiência dos critérios legais supra, permitindo ao juiz, como gestor da prova, ao avaliar as peculiaridades do caso concreto e com base nas máximas de experiência, determine quais fatos devem sem provados pelas partes. Há verdadeiro rompimento com a prévia e abstrata distribuição do ônus da prova autorizando o magistrado nos próprios termos do art.335 do CPC a tutelar corretamente os direitos fundamentais relativos ao trabalho. ${ }^{273}$

Finalizo com a precisa manifestação de Candido Dinamarco no sentido de que "a tradicional exacerbação do ônus da prova constitui postura insensível à moderna visão teleológica e instrumentalista do sistema processual. No fundo, ela é uma linha burocrática e, como burocrática que é, revela intolerável dose de comodismo: a burocracia é fruto do medo, da pobreza intelectual e do comodismo e, como já foi dito e destacado, a busca incessante da verdade não é de hoje que serve de pretexto para as práticas burocráticas. É preciso ousar. É indispensável ao juiz moderno romper com isso e vencer certos imobilismos. Onde seu espírito se considerar suficientemente capaz de afastar os 'motivos divergentes' e, como faria o homem médio da sociedade, tomar uma decisão conforme um grau satisfatório de probabilidade de acertar, que corra o risco." 274

\footnotetext{
${ }^{272}$ Interessante abordagem da questão sob o aspecto do princípio da efetividade do processo é realizada por Edmar Souza Salgado em sua dissertação O princípio da efetividade no processo do trabalho. Tese (Mestrado), Faculdade de Direito, Universidade de São Paulo, 2008, pp.180-200.

${ }^{273}$ CAMBI, Eduardo Augusto Salomão. Op.cit. pp. 341-342

${ }^{274}$ DINAMARCO, Candido Rangel. A instrumentalidade do Processo. São Paulo: Malheiros, 1993, p.252
} 


\section{Superação da técnica estática de distribuição do ônus da prova no processo do trabalho}

De tudo que vimos nos itens precedentes impõe-se a necessidade de perquirir acerca da possibilidade de flexibilização do ônus da prova no processo do trabalho. A questão, nesta perspectiva, encontra-se ultrapassada na medida em que de há muito a doutrina e a jurisprudência trabalhistas vem aplicando iterativamente a própria inversão do onus probandi em situações de reconhecido desequilibrio processual entre as partes calcadas em critérios de hipossuficiência, verossimilhança e outros.

Trueba Urbina já reconhecia a inversão do ônus da prova como uma forma de supressão de deficiências legais de forma a tutelar o trabalhador, cumprindo transcrever a lição do mestre:

"En el proceso laboral se resquebraja el principio jurídico burgués consagrado por el derecho procesal civil, relativo a que el actor debe probar los hechos constitutivos de la acción y el reo los de sus excepciones. En efecto, respecto a la carga de la prueba, la doctrina jurisprudencial laboral ha suplido deficiencias legales creando tesis sociales de inversión de la carga de la prueba, que aceptamos sin reservas cuando trata de favorecer al obrero frente al industrial, en el proceso del trabajo. Sostener lo contrario sería desconocer la naturaza la naturaleza del derecho procesal laboral en función de la necesidade de evitar que el litigante más poderoso económicamente hablando, pueda desviar y obstaculizar los fines de la justicia social. La inversión de la prueba cumple, pues, en el proceso del trabajo una función tutelar del trabajador que constituye, por otra parte, la finalidad de toda la legislación social, la que, sin perjuicio de garantizar los derechos de los factores activos de la producción en el proceso, mira con especial atención cuanto se refiere al elemento obrero y a su protección. Una solución contraria a la carga de la prueba laboral como la enfocamos, llevaría a dejar al demandante obrero en una completa indefensión, incompatible con el derecho justiciario social." 275

A insuficiência e inadequação das regras positivadas na espécie (art.333 do CPC e art.818 da CLT) já se fazem sentir há longo tempo ${ }^{276}$. Essa questão igualmente não

${ }^{275}$ TRUEBA URBINA, Alberto. Nuevo derecho procesal del trabajo. México: Ed. Porrúa, 1975, p.377

${ }^{276} \mathrm{O}$ italiano Micheli ao se referir aos critérios de distribuição do ônus da prova também se ressente da ausência de um critério de distribuição da falta de certeza afirmando a necessidade de uma melhor compreensão da extensão das regras e por fim reconhecendo a impossibilidade de formulação de um critério de atribuição do ônus 
passou despercebida por Jorge Souto Maior para quem o art.818 da CLT embora regra simples, que não faça qualquer distinção, como de resto a própria técnica convencional do CPC (art.333) o faz, não se prende a sua gênese, ou seja, o intérprete pode dar-lhe a interpretação mais consentânea com os escopos do processo e direito do trabalho ${ }^{277}$. Pela relevância da observação cumpre sua transcrição:

"De qualquer modo - não se pode negar -, o texto da CLT é vago, e a sua interpretação não está, obrigatoriamente, presa à sua gênese histórica. Isso possibilita que se faça uma interpretação criativa de seu conteúdo, para que se realize uma distribuição do ônus da prova no processo do trabalho mais condizente com as características da relação do direito material, utilizando-se da concepção de que a realização da prova compete à parte que tiver maior aptidão para a sua produção e do reconhecimento de que tal distribuição do onus probandi pode, e deve, embasar-se em critérios determinados pela presunção hominis (as máximas de experiência), que possibilitam adotar como verdadeira, até prova em contrário, a alegação verossímil". ${ }^{278}$

Igualmente Marinoni expressando uma posição alinhada com os escopos atuais do processo civil, entende a distribuição do ônus da prova a partir da classificação dos fatos como um mecanismo artificial, distribuindo os riscos do processo e o encargo da prova sem atentar para a realidade da vida que se expressa no direito material. Para esse autor a atribuição do ônus da prova não deve levar em conta as especificidades das situações de direito material e a par da existência de presunções legais relativas e normas outras que prevejam uma distribuição do ônus da prova diferente daquela exposta na regra geral do art.333 do CPC, inclusive com a sua inversão, nada obsta, que o próprio juiz, nas palavras do autor "considerando a situação de direito material controvertida, trate de forma particularizada a questão do ônus da prova, logicamente, justificando o seu procedimento". ${ }^{279}$

da prova que alcance todas as hipóteses. In MICHELI, Gian Antonio. La carga de la prueba. Buenos Aires : Ediciones juridicas Europa-America, 1961, p.310

${ }^{277}$ Ao tratar dos fins do processo do trabalho Amauri Mascaro do Nascimento afirma "tratar-se de um direito processual social, destinado tanto à tutela jurisdicional de grupos ou coletividades, como de trabalhadores. Como consequiências seguem-se as necessidades de um mínimo de formalismos, a maior liberdade interpretativa e criativa do juiz, a maior celeridade, o menor custo, a maior distributividade e menor comutatividade nos seus atos”. NASCIMENTO, Amauri Mascaro do. Curso de Direito Processual do Trabalho. São Paulo: Ed. Saraiva, 1994, p.55

${ }^{278}$ SOUTO MAIOR, Jorge Luiz. A efetividade do processo. In: CORREIA, Marcus Orione Gonçalves (org.). Curso de direito do trabalho: vol. 4 - Direito processual do trabalho. São Paulo: LTr, 2009, p. 73.

${ }^{279}$ MARINONI, Luiz Guilherme; ARENHART, Sérgio Cruz. Prova. São Paulo: Ed. Revisa dos Tribunais, 2010, pp.167-168 
Mas e a total superação da atribuição apriorística do ônus probatório com vistas viabilizar o tratamento equânime das partes será possível no processo do trabalho? Acredito não só seja possível como imensamente desejável por atender sem sombra de dúvidas aos escopos do processo trabalhista, sendo a teoria da distribuição dinâmica dos ônus probatórios a que melhor se coaduna na atual fase do pensamento contemporâneo acerca dos fins do processo. Credite-se que há doutrinadores trabalhistas ${ }^{280}$ que já tem admitido a hipótese de aplicação da teoria da distribuição dinâmica do ônus da prova. Permite-se ainda através da aplicação do ônus dinâmico da prova o alcance do mais alto grau o ideal de igualdade ${ }^{281}$ entre os homens na sua perspectiva processual.

\footnotetext{
${ }^{280}$ Registre-se por oportuno que a possibilidade de aplicação da teoria da carga dinâmica da prova ao processo do trabalho já tem sido admitida por doutrinadores a exemplo de Júlio César Bebber que assim se manifesta neste ponto: "A vagueza da redação do art.818 da CLT permite (com facilidade e sem modificação de sua literalidade) cambiar o modo de interpretá-lo, a fim de aderir ao pensamento dinâmico da prova (ampliando o seu conceito), (...); in BEBBER, Júlio César. Processo do Trabalho. Adaptação à Contemporaneidade. Tese (Doutorado), Faculdade de Direito, Universidade de São Paulo, 2009, p.159. Também Guilherme Guimarães Feliciano ao assim resumir: "A distribuição do ônus da prova no processo do trabalho já não pode mais se circunscrever ao modelo liberal e estático dado pelos artigos 818 da CLT e 333 do CPC, especialmente em razão dos direitos materiais que freqüentemente estão em jogo nos conflitos laborais. É imperioso construir um outro modelo de distribuição dinâmica do ônus probatório, que considere as circunstâncias concretas de cada caso e a natureza do interesse resistido. Nessa ordem de idéias, a jurisprudência universal vem consagrando inversões do ônus da prova em hipótese de discriminação do trabalho, de atentados ao meio ambiente laboral, de violaçães à privacidade do trabalhador e de assédio moral ou sexual in FELICIANO, Guilherme Guimarães. Distribuição dinâmica do ônus da prova no processo do trabalho - Critérios e Casuística. Revista do Tribunal Regional do Trabalho da 15. Região, n.32, 2008, p.103-112. E ainda Alessandro Severino Vallér Zenni concluindo que "a doutrina que incentiva a dinâmica das regras sobre o ônus da prova afeiçoa-se à lógica do razoável e à ordem jurídica, imprimindo celeridade e facilitação na desincumbência do ônus da prova desde que se oportunize o direito de prova em contrário. A verossimilhança nas alegações das partes exsurgida a partir das máximas da experiência, aferidas em cada situação concreta, é o veto pelo qual o juízo se guiará na inversão e redistribuição do ônus probandi" In As regras dinâmicas de distribuição do ônus da prova e a avaliação da prova no processo laboral. LTr: revista legislação do trabalho, São Paulo, v. 63, n. 07, p.918.

Contra a aplicação: Rafael Foresti Pego concluindo pela inaplicabilidade "pela ausência de fundamento legal, uma vez que o sistema brasileiro adota o critério do interesse na afirmação. Ademais, tal teoria é de difícil visualização e até mesmo aplicação prática, pois pautada em idéias de solidariedade, colaboração e isonomia, porém conferindo poderes ilimitados ao julgadores, com grande margem à arbitrariedade, relembrando antigas concepções sobre ônus da prova" In. A inversão do ônus da prova no direito processual do trabalho. Porto Alegre: Livraria do Advogado, 2009, pp.80-81.

${ }^{281}$ Estevão Mallet afasta a possibilidade de indiferença processual às situações de desigualdade material.Para o autor o processo não deve ficar neutro. Segue a transcrição: "A idéia de dever o processo permanecer neutro, indiferente à condição peculiar dos litigantes, não se sustenta e contrasta com o reconhecimento, hoje pacífico, da insuficiência da igualdade meramente formal. A legislação processual do trabalho brasileira, porém, acha-se ainda presa a tal concepção. Disso resulta o agravamento, no plano processual, das desigualdades já existentes no plano material, com sensível discriminação do litigante dotado de menor capacidade econômica. Há que reformar, pois, o processo do trabalho, de modo a combater essa discriminação, indesejável sob qualquer prisma que se queira adotar. Trata-se, no fundo, não de mera faculdade, mas de autêntico dever imposto ao legislador,
} 
Propor-se-ão algumas diretrizes como forma de manusear a técnica de distribuição dinâmica do ônus da prova no processo do trabalho através da superação das regras positivas e interpretação da nova teoria sob a ótica constitucional e de princípios constitucionais processuais de modo a pautar seus fundamentos e seus pressupostos.

\subsection{Fundamentos ou pressupostos de aplicabilidade do ônus dinâmico da prova no processo do trabalho}

Os doutrinadores trabalhistas ao aplicar técnicas de flexibilização ou inversão do ônus da prova tem se pautado em critérios norteadores de utilização da técnica, ou seja, presentes essas situações indicadoras estaria autorizado o juiz a promover a inversão do ônus da prova no processo trabalhista. $\mathrm{O}$ assunto já foi abordado no segundo capítulo com referências ainda que superficiais a alguns desses condicionantes viabilizadores da inversão do ônus da prova.

Para a defesa da aplicabilidade da teoria dinâmica do ônus da prova representaria um paradoxo a pretensão do estabelecimento de critérios na medida em que o que se busca com essa teoria é justamente o afastamento de regras apriorísticas e estáticas que determinam a conduta do juiz e das partes. Logo, como novamente teorizar antecipadamente a formulação de regras que se presentes ou ausentes seriam de observância obrigatória? Isto representaria um contra senso por justamente a atribuição do ônus dinâmico da prova partir do caso concreto e não do caso em abstrato. Preferimos, portanto, lidar com a questão através da proposição ao mesmo tempo e sob a denominação de fundamentos de alguns pontos que não só motivam a própria existência de teoria dinâmica do ônus da prova, como também podem ser considerados mais como hipóteses de orientação do interprete ao analisar as situações

como resulta do já mencionado art. 3o, inciso III, da Constituição" In MALLET, Estevão. Discriminação e Processo do Trabalho. MALLET, Estevão. Discriminação e processo do trabalho. Revista do TST. Rio de Janeiro.V.65, n.1,p.148-159, out/dezembro/99, p.154 
concretas que imprescindem da dinamização do ônus da prova para serem solucionadas com o maior grau de justiça possível.

$\mathrm{Na}$ verdade sequer podemos falar em identificação das situações "prima facie”, mas apenas e tão-somente em circunstâncias às quais estaria o juiz do trabalho adstrito a atuar prol da efetividade do processo a partir da equalização das partes através do ônus dinâmico da prova. Seriam pressupostos não exaustivos, por vezes sequer concorrentes, tudo a depender do caso concreto, pelo que passemos a sua análise geral.

\subsubsection{Observância do princípio da igualdade substancial e a aptidão para a prova}

A primeira ordem de fundamentação para aplicação do ônus dinâmico da prova o diz respeito à imperativa observância e promoção do princípio da igualdade (art. $5^{\circ}$, caput, da CF/88 e art. 125, I, 129 e 130 do CPC e art.769 da CLT) pelo juiz do trabalho nas relações processuais que lhe são submetidas par apreciação. Deve o magistrado zelar para que haja real paridade de armas das partes no feito de modo a promover o equilíbrio substancial entre elas.

A igualdade substancial no processo como já tratado no capítulo primeiro significa em síntese tratar os iguais igualmente e os desiguais desigualmente de modo que as partes atuem sob as mesmas possibilidades e com mesmos instrumentos processuais aptos a sustentar seu direito material controvertido, o que muitas vezes só será possível se atribuído o ônus da prova àquela parte que tenha efetivamente meios para satisfazê-lo ou em outras palavras materializando através do processo iguais possibilidades às partes que demonstrem suas alegações fáticas de modo a oportunizar a influência na formação da convicção do juiz sobre o caso concreto com melhor meio de implementação de acesso à justiça. 
A atenção volta-se então para as condições em que as partes se encontram e que são extremamente particulares no caso do direito do trabalho, informado que é por uma ordem de princípios gerais com características protetivas.

Nada obstante a consagração da igualdade formal ao intérprete trabalhista se impõe a amenização das desigualdades materiais das partes na relação jurídica processual, o que se consegue não só através da valoração da prova, mas especialmente na oportunização equânime dos meios de prova, aqui inserta a problemática da divisão dos encargos probatórios. A possibilidade de alteração das regras do ônus da prova de per si já tem o mérito de garantir um tratamento igualitário às partes, de modo que se justifica a interpretação judicial de maior alcance na questão.

Assim, há que se promover a igualdade de oportunidades no desenvolvimento da atividade processual respeitante às provas, de modo a assegurar a ambas as partes o poder de influir equanimente no andamento e no resultado do pleito pelo que ambas deverão ter as mesmas possibilidades de ação e estar sujeitas às mesmas limitações. ${ }^{282}$

Não há dúvidas de que o princípio da igualdade se projeta na relação processual em matéria probatória haja vista a própria disposição do art. 333, parágrafo único do Código de Processo Civil que reputa nula convenção sobre distribuição do ônus da prova quando torne "excessivamente difícil a uma parte o exercício do direito". O escopo dessa norma é evitar o desequilíbrio entre as partes de modo que alguma delas em razão de maior poderio impingisse uma situação desvantajosa para a outra. ${ }^{283}$

As partes devem se apresentar em juízo, e especificamente durante o momento processual relativo à instrução do feito, com iguais possibilidades de prova, em paridades de armas. Aliás, a promoção dessa igualdade substancial visando o equilíbrio

282 MOREIRA, Carlos Alberto Barbosa. La igualdad de las partes en proceso civil. Temas de Direito Processual: quarta série. Saraiva, 1989, p.70

${ }^{283}$ MOREIRA, Carlos Alberto Barbosa. A função social do processo civil moderno e o papel do juiz e das partes na direção e instrução do processo. In Revista de Processo São Paulo, no. 7, jan/março de 1985 p.141. 
processual dos litigantes representa também o fundamento do próprio aumento dos poderes instrutórios dos juízes no processo.

A questão da desigualdade das partes no processo do trabalho é muito sensível, vez que nesta esfera processual a disparidade de forças na maioria dos casos é latente, apresentando-se como situação mais comum de conflito aquela entre a pessoa física do trabalhador e uma ou mais empresas ou organização empresarial. ${ }^{284}$

Não bastasse a Constituição Federal demandar energicamente pela igualdade de todos, a legislação infraconstitucional também o faz atribuindo expressamente a tarefa ao juiz nos termos do art.125, I do CPC de "assegurar às partes igualdade de tratamento". Exige a lei portanto um comportamento ativo do magistrado de modo a que, através de suas condutas processuais, garanta às partes a igualdade substancial de tratamento no decorrer da demanda.

Importa pois ao juiz do trabalho e com amparo em seus amplos poderes no processo (art.765 da CLT) colocar as partes em igualdade de condições na busca das provas aptas e necessárias ao descobrimento da verdade no processo. Um primeiro condicionante, seguindo-se este fundamento, para a aplicação da teoria do ônus dinâmico seria a constatação da desigualdade das partes para a produção da prova de modo que o encargo da sua produção será transferido para a parte adversa quando esta dispuser de melhores condições (o que no processo do trabalho têm se expressado muito bem através do reconhecimento da existência de um princípio de aptidão para a prova).

\footnotetext{
${ }^{284}$ Ao tratar da questão da igualdade das partes no processo civil Barbosa Moreira já apontava como uma situação clássica de disparidade de forças no processo a que contrapunha uma pessoa física a um adversário que desfruta das vantagens de uma organização ou da superioridade de recursos econômicos ou ainda de influência política. Reconhece, ainda, esse autor ser difícil remediar esse desequilíbrio. Idem. Ibidem.
} 
Na esfera probatória a promoção da igualdade substancial imprescinde de uma atitude mais incisiva ou proativa do juiz o que acarreta o abandono da postura da neutralidade não da imparcialidade, como muitos querem fazer crer em objeção aos critérios de relativização do ônus estático da prova. Haveria parcialidade se o juiz frente a uma situação de desigualdade material entre as partes permanecesse inerte aguardando apenas a derrota de uma frente à mais poderosa. Bedaque bem observa a questão afirmando a respeito da regra estática ser a mesma decorrente de "um superado liberal-individualismo, que não mais satisfaz as necessidades da sociedade moderna, pois pode levar as partes a uma atuação de desequilíbrio substancial". ${ }^{285}$

De fato, "a real igualdade da partes no processo constitui valor a ser observado sempre, ainda que possa conflitar com outro princípio processual”. ${ }^{286}$

Nem se olvide que, historicamente, no processo do trabalho os juízes são naturalmente proativos em matéria de prova, denotando os reflexos dos amplos poderes instrutórios do juiz do trabalho que guardam consonância com os escopos deste processo especializado. Nessa esteira o reconhecimento até mesmo de idéias de poderes "assistenciais" conferidos aos juízes consoante ensina Marcus Orione Gonçalves Correia:

“Os poderes assistenciais do juiz defluem, em prestígio à noção de justiça material (em contraposição à mera idéia de justiça formal), de um princípio, por alguns admitido - que não vem expresso na Constituição, conhecido como princípio da paridade das armas.

Segundo desdobramento deste último princípio, é indispensável, para a própria garantia da igualdade das partes nos processo, que, em situações de desigualdade, o juiz atue conduzindo o processo e assistindo o mais frágil na relação jurídica deduzida em juízo “287

A base, portanto, nos termos do art. $5^{\circ}$ da Constituição da República é a da igualdade, não só formal (igualdade na lei), mas a substancial, que considera a particularidade

\footnotetext{
${ }^{285}$ BEDAQUE, José Roberto dos Santos. Poderes instrutórios do juiz. São Paulo: Revista dos Tribunais, 2001, p.97

${ }^{286}$ Idem.Ibidem. p.99

${ }^{287}$ CORREIA, Marcus Orione Gonçalves. Direito Processual Constitucional São Paulo: Saraiva, 1998, p.13.
} 
dos sujeitos, o que importa sobremaneira na esfera processual trabalhista dada a situação recorrente de hipossuficiência de um dos litigantes.

Essa hipossuficiência normalmente será de ordem econômica, mas também poderá ser de ordem técnica em virtude até mesmo da carência de acesso às informações pelo trabalhador. A questão da hipossuficiência por déficit de informações é agravada ainda mais no contexto das relações laborais no Brasil onde não se encontra positivado um dever geral de informações dos empregadores aos empregados, ao contrário do que ocorre, por exemplo, na União Europeia em que há Diretiva específica sobre o tema (direito de informação e consulta dos trabalhadores - Diretiva 2002/14 ${ }^{288}$ ).

Manoel Antonio Teixeira Filho ao delinear os princípios do processo do trabalho reconheceu, como específicos desse ramo apenas dois deles, a saber, o princípio da correção das desigualdades e o do poder normativo. Para o processualista do trabalho, a exemplo do que já ocorre no plano do direito material, impõe-se sejam conferidos meios ao trabalhador que lhe possibilitem litigar em igualdade de condições, dada a sua desigualdade econômica e técnica. ${ }^{289}$

A vulnerabilidade econômica, por vezes notória do trabalhador se irradia nas relações processuais, sendo que a própria demora no andamento do processo já se consubstancia num fator de agravamento da situação desse ator processual mais fraco. Além da problemática do tempo do processo, outra conseqüência derivada da inferioridade econômica e já atenuada de certa forma, diz respeito aos custos do processo. Nesse particular a legislação trabalhista já confere ao trabalhador, por exemplo, benefícios de assistência

288 Segue trecho da Diretiva:1. A presente diretiva tem por objetivo estabelecer um quadro geral que defina requisitos mínimos quanto ao direito à informação e à consulta dos trabalhadores nas empresas ou nos estabelecimentos situados na Comunidade; 2. A informação e a consulta incluem: a) A informação sobre a evolução recente e a evolução provável das atividades da empresa ou do estabelecimento e a sua situação econômica. b) A informação e a consulta sobre a situação, a estrutura e a evolução provável do emprego na empresa ou no estabelecimento e sobre as eventuais medidas de antecipação previstas, nomeadamente em caso de ameaça para o emprego; c) A informação e a consulta sobre as decisões susceptíveis de desencadear mudanças substanciais a nível da organização do trabalho ou dos contratos de trabalho, incluindo as abrangidas pelas disposições comunitárias referidas no n.o 1 do artigo 9.o" in http://eur-lex.europa.eu/pt/index.htm. Acesso em $10 / 12 / 2010$. 
judiciária gratuita, isenção de custas, e outros inibidores desse fator perverso de ordem econômica. $^{290}$

Mas interessa-nos especificamente uma segunda ordem de manifestação de inferioridade do trabalhador, consistente na propalada natureza técnica e que se reflete justamente na produção de provas, vez que para aquele as dificuldades na produção de provas são bem maiores do que as possibilidades do empregador. $\mathrm{O}$ trabalhador normalmente não tem recursos para conduzir testemunhas até o fórum e até mesmo essas pessoas se ressentem de dificuldades econômicas e receios outros de perda do próprio emprego em razão da ausência para depor em Juízo. Não tem ainda o trabalhador acesso à maioria dos documentos do contrato de trabalho. De fato, por maior que seja o empenho do empregado para obter sucesso na demanda, há inúmeras situações em que somente é possível a produção da prova pela obtenção dos meios que estão na posse do adversário, o qual, em regra, não tem interesse na sua produção. O empregador tem a sua disposição todos os documentos relativos à relação jurídica contratual, bem assim suas testemunhas normalmente ainda lhe prestam serviços, sendo tomadas, ainda que o juiz as advirta sobre as consequiências de seus atos em juízo, de um temor latente frente a uma possível situação de desemprego futuro ${ }^{291}$.

Um dos atores processuais trabalhistas normalmente tem como característica a vulnerabilidade ${ }^{292}$ o que lhe limita a própria autonomia da vontade para consentir, discordar, produzir provas. Vulnerabilidade decorrente de uma relação material de desigualdade seja cultural, econômica, que demanda compromisso ético do juiz por ocasião da prestação jurisdicional de proteção do mais fraco em relação ao mais poderoso.

\footnotetext{
${ }^{289}$ TEIXEIRA FILHO, Manoel Antonio. Curso de Direito Processual do trabalho. São Paulo: LTr, 2009, p.93

${ }^{290}$ Idem.Ibidem, pp.93-94

${ }^{291}$ Idem.Ibidem, p.95

${ }^{292}$ Emília Simão Albino Sako aponta que o estado de miserabilidade, vulnerabilidade e fraqueza na sua vertente econômica dificultam a produção das provas pelo trabalhador. In. A prova no processo do trabalho: os meios de prova e o ônus da prova nas relações de emprego e trabalho. São Paulo: LTr, 2006, p.33.
} 
A ideia da aplicação do ônus dinâmico da prova também parte, portanto, da perspectiva de igualar uma situação, a priori, assimétrica.

Atahualpa bem delineou a questão da desigualdade como critério para distribuição do ônus da prova afirmando que

"o juiz, pois, como sujeito da compreensão ou agente conformador, deve atuar como um mediador entre partes que procedem reciprocamente como antagonistas em um conflito que não é, ontologicamente, summa zero: p.e., a situação típica inicial em um litígio trabalhista. A função judicial básica, por conseguinte, deve consistir em buscar uma solução que na medida do razoável, iguale os meios objetivos dos litigantes e maximize as utilidades que as partes possam lograr, diminuindo os custos probatórios que devam paliar. Se adverte, assim, que as valorações (nomeadamente as probatórias) que devem orientar as decisões judiciais não são unicamente aquelas preferenciais, muito genéricas e simétricas, que podem resultar de alguma idéia da justiça ou de outros valores um tanto abstratos (como o da igualdade dos litigantes), senão das preferências concretas e circunstanciais que levam o juiz a considerar a versão sobre as vicissitudes do caso, nomeadamente no que se refere à desigual dotação inicial de recursos das partes litigantes. Adverte ainda o autor que "o juiz que realiza o direito positivo, conforme ao direito, corre o risco de mover-se exclusivamente no campo desenhado pelas normas legisladas, sendo que, nesse sentido, sua decisão jamais será arbitrária ou discricional. Contudo, ainda a mais estrita das aplicações do direito conserva uma irredutível frincha de subjetividade, pois as decisões dos juízes são, sem mais, decisões que tocam os seres humanos, para modificar as expectativas de outros homens." 293

Uma das formas para correção dessa desigualdade como forma de sublimar a vulnerabilidade do trabalhador se daria, portanto, sob este viés do ônus da prova ${ }^{294}$, atribuindo-se o encargo de forma dinâmica, avaliando o juiz cada caso, cada dificuldade ou situação de desigualdade.

\footnotetext{
${ }^{293}$ FERNANDEZ NETO, Atahualpa. A desigualdade como critério de distribuição do ônus da prova. Revista do Ministério Público do Trabalho. Brasília/DF, n. 23, p. 128, mar. 2002.

${ }^{294}$ Manoel Antonio Teixeira Filho afirma expressamente que "a fórmula pela qual o legislador deve anular essa inferioridade do trabalhador será deslocando, cada vez mais, o ônus da prova par ao empregador, (...) ao mesmo tempo em que deve semear considerável quantidade de presunções em benefício daquele(...). ob.cit., pp.96-97
} 
O princípio da igualdade substancial trata-se, portanto, de verdadeiro imperativo que na seara probatória e imprescinde de interpretação judicial que propicie o maior alcance para aplicação das normas relativas ao ônus da prova. As regras tradicionais já demonstraram sua insuficiência justamente por não atender às peculiaridades e circunstâncias que levam às partes às situações de desigualdade no caso concreto.

A abordagem de Estêvão Mallet ao analisar a questão da discriminação no trabalho se reveste de clara importância ao admitir o autor a insuficiência das regras clássicas de distribuição do ônus da prova, calcadas que são na igualdade formal das partes. Referidas regras a fim de que não se configurem como obstáculo à tutela judicial dos direitos dos trabalhadores não poderiam deixar de observar as "possibilidades reais e concretas, que tem cada litigante de demonstrar suas alegações", a fim de que o ônus possa ser alterado e não pese apenas sobre quem alega, mas sobretudo recaia sobre a parte processual que detenha as melhores condições de produção da prova imprescindível ao deslinde do processo. Admite o autor expressamente nesses casos a inversão do ônus da prova de forma que as dificuldades para a produção da prova, e que são próprias do plano do direito substancial a partir da “desigual posição das partes litigantes", não sejam transpostas para o processo. Conclui o autor com isso pela facilitação da descoberta da verdade e a possibilidade de tutela a situações que se assim não fosse ficariam desprotegidas. ${ }^{295}$

Em suma, a questão aqui será a de atribuição do ônus da prova à parte que poderia se desincumbir da tarefa com menor dificuldade, privilegiando-se com esta técnica o tratamento apto à igualar no processo os desiguais. Logo, a aptidão para prova como pressuposto de atribuição dinâmica do ônus da prova é decorrência lógica do reconhecimento constitucional da igualdade substancial.

${ }^{295}$ MALLET, Estêvão. Discriminação e processo do trabalho. Revista do TST. Rio de Janeiro. V. 65, n.1, out/dez 1999, p. 154. 
Aptidão para a prova significa sua produção por quem a detenha ou tenha melhor possibilidade de acesso à mesma, independentemente de sua posição processual, ou seja, se autor ou réu. O próprio conceito de aptidão fala por si, influenciando diretamente na atribuição do ônus da prova a uma das partes, no caso, a que tenha detenha a prova imprescindível à demanda. Pela aplicação deste princípio um encargo que originariamente seria, por exemplo, do autor de trazer aos autos alguma prova relevante e ele só não o faz por conta da presença de fatores externos impeditivos (hipossuficiência de informações, econômica, ou de nível educacional) que conduzem a uma situação de impossibilidade de obtenção da prova ou uma extrema dificuldade nesse sentido, o encargo será atribuído à parte adversa.

Em síntese será importante que o juiz valore as circunstâncias particulares de cada caso e aprecie quem se encontra em melhores condições para a prova do fato controvertido bem assim as razões pelas quais quem teria que provar não o fez. As regras do ônus da prova devem ser apreciadas em função da índole do direito material discutido.

Márcio Túlio Viana nos ensina que o princípio da aptidão para a prova é referência antiga, pois Carnellutti já admitia a "conveniência de atribuir a prova à parte que esteja mais provavelmente em situação de dá-la, e assim com base numa regra de experiência, a qual estabelece qual das duas partes esteja em condições melhores para fornecer a prova do fato", de modo que segundo o autor italiano, "unicamente assim o ônus da prova constitui um instrumento para alcançar o escopo do processo, que é, não a simples composição, mas a justa composição da lide; por isso recai sobre a parte que pode levar mais útil contribuição à convicção do juiz; e por isso, onde esta convicção deve formar-se na falta da prova, isto é, onde o juiz deva abandonar uma afirmação só porque a parte não a provou, oferece a probabilidade máxima da coincidência desta convicção com a verdade". ${ }^{296}$

\footnotetext{
${ }^{296}$ Carnellutti citado por Evaristo de Moraes Filho, in MORAES FILHO, Evaristo. A justa causa na rescisão do contrato de trabalho.Rio de Janeiro:Ed.Forense, 1968, p.277, apud VIANA, Márcio Túlio. Critérios para a inversão do ônus da prova no processo trabalhista. $L T r$ : revista legislação do trabalho, São Paulo, v. 58, n. 10, p.1223, out/1994.
} 
Própria, no particular, a manifestação de Fabiano Coelho de Souza ao afirmar que "com intensa aproximação finalística com a inversão do ônus da prova, o princípio da aptidão probatória indica que a prova deva ser produzida por aquela parte que a detém ou que tem acesso à mesma, sendo inacessível à parte contrária. Tal regra é necessária para que não seja imposta uma carga probatória desmedida a um dos litigantes. Não se trata, porém, de inversão, mas sim, de distribuição do ônus com base na capacidade probatória de cada um. Ou seja, o ônus sequer chega a ser imposto a quem não detém a aptidão probatória." 297 Assim, aproxima-se este autor também do reconhecimento da concepção da dinamização do ônus da prova no processo do trabalho admitindo-a expressamente ao que tudo indica.

Sob o aspecto relativo às melhores condições de prova a doutrina argentina, aqui representada por Barberio, vem respondendo a essa questão afirmando que ela se revela no sujeito que detenha uma situação privilegiada na relação material frente a parte contrária, ou seja, há que se levar em conta não só papel do direito substancial que rege a controvérsia, mas também quem está em posse da coisa ou instrumento probatório, apresentando inclusive maiores possibilidades de contribuir para a revelação da verdade em verdadeira homenagem ao princípio da colaboração que pode ser acentuado até o ponto de atribuir o encargo da prova àquele que não o teria originariamente. Também se credita, naquele país, a melhor posição probatória por razões profissionais, técnicas, econômicas ou jurídicas. ${ }^{298}$

Registre-se ainda que o próprio juízo sobre a maior facilidade de acesso ou de produção a prova é suscetível de variação e desta forma será mais legítimo que a lei ou o juiz digam quem está em melhores condições de produzir a prova e este esclarecimento deve

${ }^{297}$ SOUZA, Fabiano Coelho de. O princípio da pré-constituição das provas n processo do trabalho. Revista Trabalhista Direito e Processo. São Paulo, no. 31 - outubro, 2009, p.155.

${ }^{298}$ Ensina Barberio que "pues que el sujeto a quien se atribuye la carga probatoria reviste una posición privilegiada o destacada con relación al material probatório y de cara a su contraparte. Es decir que, en virtud del rol que desempeñó en el hecho generador de la controversia, por estar en posesión de la cosa o instrumento probatorio o por ser el único que "dispone" de la prueba, etcétera, se encuentra en mejor posicion para revelar la verdad y su deber de colaboración se acentúa al punto de atribuirle una carga probatoria que, en principio, según las clásicas reglas que mencionamos más arriba, no tenía. Las mejores condiciones de aportar la prueba, se ha sostenido, pueden tambien fundarse en razones profesionales, técnicas, económicas o jurídicas" BARBERIO, Sergio José. Cargas probatórias dinámicas. Qué debe probar El que no pude probar? In.: 
se verificar em momento apto a possibilitar que a parte agora onerada atue no sentido da produção de tal prova. ${ }^{299}$

Uma questão que pode ser colocada é se a melhor aptidão para a prova deve ser provada ela própria como condição de produção de prova.

Na doutrina argentina é novamente Barberio quem afirma que a condição de melhor aptidão para a prova deve ser atestada ainda que indiretamente pois a distribuição dinâmica pode trasladar uma maior carga probatória para a outra parte e ao beneficiário desse deslocamento haveria que se exigir a indicação dessa condição de melhor aptidão da parte contrária. $^{300}$

Outro questionamento trazido pela doutrina estrangeira é proposto por Rui Rangel que ao tratar da inversão do ônus da prova afirma que a dificuldade na produção da prova não é só por si motivo apto a fundamentar uma alteração dos encargos da prova. Relembra o autor português que essa dificuldade de acesso e produção da prova sofre constantemente tentativas de solução legislativa o que no entender do autor não se tem mostrado saudável. ${ }^{301}$

Quanto à impossibilidade ou dificuldade da prova para as duas partes Marcio Túlio Viana acaba por defender a onerosidade do empregador, seja por que devesse ser precavido e em última análise, por ter criado o risco da demanda, suportando em razão disso também o risco pela não produção da prova ${ }^{302}$. Entretanto a questão é mais complexa

PEYRANO, Jorge W.(dir.); LÉPORI WHITE, Inês (coord.). Cargas probatorias dinámicas. Buenos Aires: Rubinzal-Culzoni, 2004, p.101.

${ }^{299}$ YARSHELL, Flávio Luiz. Antecipação da Prova sem o requisito da urgência e o Direito Autônomo à Prova. São Paulo: Malheiros, 2009, p.95

${ }^{300}$ BARBERIO, Sérgio José. Op.cit.103

${ }^{301}$ RANGEL, Rui Manuel de Freitas. O Ônus da prova no processo civil. Coimbra: Livraria Almedina, 2000, p. 178

302 VIANA, Márcio Túlio. op.cit. p.1223. 
encontrando limite inclusive na esfera da probatio diabolica, na medida em que também não será legítimo criar uma situação de prova impossível para a outra parte. ${ }^{303}$

Afinal se a idealização da carga probatória dinâmica reside justamente no ideal de equalização substancial das partes no processo, o limite legitimador da aplicação da nova teoria passa também pela impossibilidade de carrear à outra parte prova impossível de modo a negar desta feita ao outro litigante a aplicação dessas mesmas bases de igualdade. ${ }^{304}$ Nesses casos a convicção do juiz do trabalho observaria outras bases a exemplo da verossimilhança ou da redução do módulo de prova, ou seja, entendendo o juiz que o critério de verossimilhança já baste para sua decisão, sequer precisa se valer de regras de ônus da prova, pois não estaria mais em dúvida.

Ademais, essa primeira abordagem quanto à possibilidade de atribuição dinâmica do ônus da prova considerando como fundamento inicial a concreção da igualdade substancial das partes, não pode ser vista de forma destacada como um critério.

Ora o ônus da prova dinâmico parte de uma fundamentação inicial de busca da igualdade de fato ou substancial na relação jurídica processual num dos setores mais críticos e importantes do processo que é a atividade instrutória, sendo o princípio da aptidão da prova um dos componentes a ser utilizado de forma ponderada e proporcional pelo intérprete a vista de cada situação concreta.

Passemos agora a uma segunda ordem de pressupostos ou diretrizes para adoção da teoria dinâmica do ônus da prova a partir do próprio direito fundamental à prova.

\footnotetext{
${ }^{303}$ Exemplo clássico de prova diabólica a de determinar a uma parte que prove que a outra "nunca" trabalhou para si.

${ }^{304}$ Também na doutrina argentina advertindo para o problema da probatio diabólica Sergio José Barberio, Cargas probatórias dinámicas. Qué debe probar El que no pude probar? In.: PEYRANO, Jorge W.(dir.); LÉPORI WHITE, Inês (coord.). Cargas probatorias dinámicas. Buenos Aires: Rubinzal-Culzoni, 2004, p.104 e na nacional Artur CARPES, Artur Thompsen. Prova e Participação no Processo Civil: Dinamização dos ônus probatórios na perspectiva dos direitos fundamentais. Tese (Mestrado), Faculdade de Direito, Universidade Federal do Rio Grande do Sul, 2008, pp.93-98
} 


\subsubsection{Direito fundamental à prova, pré-constituição da prova, máximas de experiência e verossimilhança}

$\mathrm{O}$ reconhecimento do direito fundamental à prova emanará no processo do trabalho uma ordem de justificação muito expressiva apta a exigir o pleno acolhimento da teoria dinâmica do ônus da prova. De fato, "possuindo uma das partes melhores condições de provar, segundo as circunstâncias materiais do caso concreto, a dinamização funciona como filtro isonômico do direito fundamental à prova: o exercício desse direito é ajustado em concreto, evitando tratamento discriminatório a qualquer das partes na sua atividade probatória em face da distribuição estática positivada na lei”. 305

Na medida em que o direito à prova é reconhecido inclusive como uma extensão do próprio princípio de acesso à justiça (na sua compreensão inclusive como acesso a um processo justo e equânime), todos os seus desdobramentos gozam desse status, em especial as regras do ônus da prova que se tecnicamente mal manipuladas podem afetar negativamente a tutela jurisdicional dos direitos e ferir mortalmente direitos fundamentais.

Em homenagem a esse direito fundamental das partes, há que se referir aqui à própria aplicação do princípio da pré-constituição de provas bem assim à utilização das máximas de experiência e presunções como diretrizes abalizadoras na atribuição dinâmica do ônus da prova no processo do trabalho, em que pese, repita-se, a distribuição dinâmica não deva conter critérios apriorísticos e sim buscar seu conteúdo nos próprios princípios fundamentais.

Pelo princípio da pré-constituição da prova se impõe o ônus da prova àquela parte sujeita a uma obrigação legal de produção ou manutenção de documento em seu

poder. Para Reis de Paula este é um princípio que representa uma variante em relação à prova 
documental $^{306} \mathrm{e}$, ainda que não seja da essência do contrato de trabalho a forma escrita, vez que pode ser acordado tacitamente nos termos do art.442 da CLT, fato é que vários outros atos da relação contratual são registrados formalmente, inclusive com previsão legal de sua existência.

Assim temos como regra geral que a posse dos documentos relativos ao contrato de trabalho normalmente é do empregador que exerce seu poder potestativo fazendo com se configure, através da relação de subordinação jurídica uma situação de desigualdade material no que tange também às possibilidades probatórias em caso de eventual conflito decorrente dessa relação substancial. Diga-se como regra geral, que encontra suas exceções especialmente configuradas nas novas matérias de competência trabalhista, a saber, outras relações de trabalho, que não só as de emprego, e nas quais eventualmente as partes (autor e réu) não se encontrem no desnível próprio da relação de emprego. Nestes casos também deverá haver o correto sopesamento das próprias condições probatórias das partes, percebendo-se nesta hipótese também os benefícios da teoria dinâmica do ônus da prova facilmente adaptável ao caso concreto.

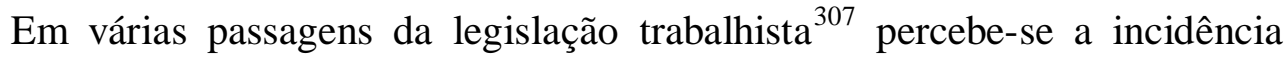
desse princípio a exemplo do art. 464 da CLT, que aponta para a obrigatoriedade da existência do recibo de pagamento de salários por parte do empregador, o que demonstra não só que este deve tê-los em seu poder e apresentá-los em juízo quando reclamado e também sua aptidão para a prova no particular.

${ }^{305}$ CARPES, Artur Thompsen. Prova e Participação no Processo Civil: Dinamização dos ônus probatórios na perspectiva dos direitos fundamentais. Tese (Mestrado), Faculdade de Direito, Universidade Federal do Rio Grande do Sul, 2008, p.89.

${ }^{306}$ PAULA, Carlos Alberto Reis de. A especificidade do ônus da prova no processo do trabalho. São Paulo: LTr, 2001, p. 145

${ }^{307}$ Previsão no art.13 da CLT quanto à obrigação de anotação da Carteira de Trabalho; art.74, parágrafo segundo da CLT com obrigação de manutenção de registro de horário de trabalho em empresas com mais de dez empregados, art.135, caput e parágrafo segundo com determinação de concessão e pagamento de férias por escrito; art.464 da CLT determinando pagamento de salários mediante recibo; art.477 da CLT que prevê 
Registre-se ser eficaz o simples requerimento da parte autora para que o réu traga aos autos os documentos com as quais pretende a prova dos fatos independentemente de ordem judicial para tanto em face do que determina o espírito do próprio princípio da préconstituição de provas, associado aos deveres de colaboração e boa-fé processuais. Aliás, tratando-se de verdadeiro dever, não há se falar sequer na necessidade de requerimento pelo autor da juntada aos autos, por exemplo, dos recibos de pagamento salariais, consubstanciado em absoluta obrigação legal do empregador sua apresentação nos autos de processo judicial envolvendo disputa salarial. Nesse sentido Jorge Luiz Souto Maior ao entender que "a não juntada dos documentos não é, então, apenas uma falha processual, mas a demonstração de um descumprimento legal, um fato que gera uma presunção em favor do empregado. Essa conclusão se reforça quando a exigência da prova pré-constituída advém de uma previsão legal". 308

Em síntese e a partir dos próprios dispositivos legais que determinam a existência e manutenção de documentos há que se atribuir, a priori, o ônus da prova quanto aos fatos subjacentes às realidades retratadas nessa documentação àquele ator processual a quem a lei atribuiu a incumbência de sua constituição.

Questão emblemática e atual acerca da pré-constituição de provas diz respeito ao disposto na Súmula no. 338 do Tribunal Superior do Trabalho, que assim dispõe:

\footnotetext{
SUM-338 JORNADA DE TRABALHO. REGISTRO. ÔNUS DA PROVA (incorporadas as Orientações Jurisprudenciais ns 234 e 306 da SBDI-1) Res. 129/2005, DJ 20, 22 e 25.04.2005

I - É ônus do empregador que conta com mais de 10 (dez) empregados o registro da jornada de trabalho na forma do art. $74, \S 2^{\circ}$, da CLT. A não-apresentação injustificada dos controles de frequência gera presunção relativa de veracidade da jornada de trabalho, a qual pode ser elidida por prova em contrário
}

formalidade para o pedido de demissão de empregado com mais de um ano de serviços prestados, exigindo-se inclusive homologação como assistência sindical ou frente ao Ministério do Trabalho.

${ }^{308}$ SOUTO MAIOR, Jorge Luiz. Direito Processual do Trabalho. Efetividade, Acesso à Justiça e Procedimento oral. São Paulo: LTr, 1999, p.176 
II - A presunção de veracidade da jornada de trabalho, ainda que prevista em instrumento normativo, pode ser elidida por prova em contrário.

III - Os cartões de ponto que demonstram horários de entrada e saída uniformes são inválidos como meio de prova, invertendo-se o ônus da prova, relativo às horas extras, que passa a ser do empregador, prevalecendo a jornada da inicial se dele não se desincumbir. ${ }^{309}$

A súmula em tela demonstra claramente que apenas a alegação de trabalho em horas extras não é suficiente para alteração das regras do ônus da prova transferindo-as para o empregador, não sendo sequer fator de verossimilhança ${ }^{310}$. A exigência de préconstituição da prova é legal (art.74 da CLT), de modo que a ausência desses documentos nos autos de pronto já autorizaria a atribuição do ônus da prova ao réu pela aplicação do princípio da pré-constituição das provas. Pode-se vislumbrar aqui a dinamização do ônus da prova em favor do autor porquanto não se trata de verdadeira hipótese de inversão do ônus probandi, mas de técnica processual que focada na concretização do acesso à justiça sob o prisma também da manutenção da igualdade substancial das partes as iguala no processo em matéria probatória.

Especificamente em relação a esta questão intrincada cumpre registrar a exata percepção de Jorge Luiz Souto Maior ao analisar o ônus da prova a partir do disposto no art.74, parágrafo segundo da CLT:

"Não se trata, por isso, em princípio, de inversão do ônus da prova, nem de privilegiar a prova documental em detrimento da prova oral, que, normalmente, deve ter mais força que aquela, uma vez que documentos podem sempre ser forjados. É isto sim, uma fórmula processual, baseada na garantia do contraditório, que visa igualar as partes, frente ao instituto da prova - e, para tanto, um tratamento desigual para desiguais é essencial - impondo uma obrigação a mais

\footnotetext{
${ }^{309}$ Histórico da Súmula: Súmula alterada - Res. 121/2003, DJ 19, 20 e 21.11.2003: No 338 Jornada. Registro. Ônus da prova. É ônus do empregador que conta com mais de 10 (dez) empregados o registro da jornada de trabalho na forma do art. $74, \S 2^{\circ}$, da CLT. A não apresentação injustificada dos controles de frequência gera presunção relativa de veracidade da jornada de trabalho, a qual pode ser elidida por prova em contrário. Redação original - Res. 36/1994, DJ 18, 21 e 22.11.1994 No 338 Registro de horário. Inversão do ônus da prova A omissão injustificada por parte da empresa de cumprir determinação judicial de apresentação dos registros de horário (CLT, art. $74 \$ 2^{\circ}$ ) importa em presunção de veracidade da jornada de trabalho alegada na inicial, a qual pode ser elidida por prova em contrário.

${ }^{310}$ SOUTO MAIOR, Jorge Luiz . op cit. Efetividade... p.176
} 
para os empregadores - equilibrando as forças dos agentes da relação de emprego" 311

Há entretanto que se pensar qual a exata dimensão da possibilidade de ser elidida a presunção favorável ao trabalhador pela não juntada de documentos obrigatórios, ou pela juntada de documentos de registro inadequados (anotações invariáveis). Há que registrar que mesmo no caso da pré-constituição de prova a diretriz para subsidiar a aplicação da distribuição dinâmica do ônus da prova é fluída e casuística vale dizer, dependerá absolutamente do caso concreto ${ }^{312}$. Tratando-se, por exemplo, de uma hipótese simples em que a empresa deveria ter carreado os controles de ponto, não o fez e nada justificou, não poderia produzir outra prova (aqui, registre-se, considerando-se também o pressuposto relativo ao princípio da boa-fé), reputando-se verdadeira a jornada indicada na petição inicial. Também e apenas a título de exemplo se a empresa comprovasse um incêndio no setor onde arquiva os controles de ponto, sob pena de malferimento ao contraditório e via de consequiência da própria legitimação da atuação jurisdicional deveria ser oportunizada a produção de prova para elidir a presunção de correção de jornada inicial ${ }^{313}$. Em suma, qualquer situação de atribuição de ônus probatória vai depender, de fato, do caso concreto, de cada alegação, havendo que se resistir à tentação do estabelecimento de critérios estáticos,

\footnotetext{
${ }^{311}$ Idem,Ibidem, p.177. A ideia do autor é a de que 'no caso da alegação de horas extras não há inversão do ônus da prova, vez que a prova do fato constitutivo continua sendo do reclamante. Apenas cria-se, com a exigência dessa prova documental, que pode facilmente ser produzida pelo empregador, demonstrando, aliás, sua responsabilidade quanto às obrigações trabalhistas, um obstáculo processual a mais para o empregador, na tentativa de equilibrar a atuação processual dos desiguais: empregados e empregadores. A mera alegação de trabalhão em horas extras não é, por si só, um fator de verossimilhança que pudesse justificar a inversão do ônus da prova, a não ser em circunstâncias especiais. Já a ausência dos documentos probatórios da jornada de trabalho gera a presunção de que o empregador não é um fiel cumpridor das obrigações trabalhistas e que, por isso mesmo, muito provavelmente teria ferido os direitos pleiteados pelo reclamante." (...) Continua o autor, "em outras palavras, um postulado do instituto da prova no processo do trabalho é o de que os empregadores devem provar documentalmente suas alegações,quando se tratar do cumprimento de alguma obrigação legal, independentemente de determinação legal".p.176-177.

312 Mesmo para Márcio Túlio Viana a pré-constituição de prova como critério de inversão do ônus da prova aponta o seguinte critério rígido concluindo " que toda vez que a lei,por uma razão ou por outra exigir a preconstituição da prova, e o empregador não cumprir a exigência, o ônus probandi se inverte. E pouco importa se o juiz determinou ou não que a parte trouxesse aos autos a prova legalmente exigida: tal como acontece com os recibos de salário, cabe ao interessado a iniciativa de sua juntada" op.cit. p.1224.

${ }^{313}$ Sérgio Pinto Martins ao tratar da questão da omissão injustificada dos registros de horário aponta para a existência de uma presunção relativa (iuris tantum), permitindo-se a empresa fazer prova em sentido contrário.In. Direito processual do trabalho. São Paulo: Atlas, 2000, p.285
} 
pois estes já existem e estão registrados no art.333 do CPC e art.818 da CLT e dos quais pretendíamos nos desvencilhar ao menos em algumas hipóteses.

Ultrapassada a questão, há que se abordar ainda do ponto de vista do debate probatório as denominadas máximas de experiência considerado seu perfil de instrumento viabilizador de atribuição do ônus da prova e não só como critério de formação da convicção quando do julgamento.

Com efeito, o juiz ao apreciar o direito embora utilize todo seu conhecimento jurídico, como ser de um mundo real, observa tudo e todos e assim, é dotado de outros tantos conhecimentos em várias áreas, fruto de sua cultura geral e experiências vividas. Essas noções são as máximas de experiência, oriundas dos juízos realizados sobre o que de ordinário acontece. Como conceito as regras de experiência são as "noções que refletem o reiterado perpassar de uma série de acontecimentos semelhantes, autorizando, mediante raciocínio indutivo, a convicção de que, se assim costuma apresentar-se as coisas, também assim devam elas, em igualdade de circunstâncias, apresentar-se no futuro", possuindo, portanto, características de generalidade e abstração. ${ }^{314}$

As máximas da experiência se referem, portanto, às conclusões extraídas de do que ordinariamente acontece no comportamento social e não da existência do próprio evento e podem ser utilizadas pelo juiz por expressa autorização do art. 335 do CPC $^{315}$ com aptidão, portanto, de redistribuição do ônus da prova, visando à apuração efetiva dos fatos especialmente a partir da equalização que também podem projetar sobre a relação processual.

Registre-se ainda que o art. 852-D da CLT expressa que "o juiz dirigirá o processo com liberdade para determinar as provas a serem produzidas, considerado o ônus

\footnotetext{
${ }^{314}$ DIDIER JR, Fredie; BRAGA, Paula Sarno; OLIVEIRA, Rafael. Curso de Direito Processual Civil vol.2. Salvador: Juspodivm, 2009, p.53
} 
probatório de cada litigante, podendo limitar ou excluir as que considerar excessivas, impertinentes ou protelatórias, bem como para apreciá-las e dar especial valor às regras de experiência comum ou técnica". (g.n.).

Dessas máximas emanam presunções comuns, e em geral a doutrina clássica tem de fato conferido a estas uma função de auxílio na valoração da prova, mas sem se alterar o ônus da prova, conclusão não aceita por Márcio Túlio Viana que ensina, com base nas lições de Pistolese e Pescatore que os critérios de experiência comum devem ser sim utilizados no direito processual do trabalho a fim de corrigir as desigualdade de forças, principalmente quando apontarem na mesma direção da alegações do trabalhador invertendo, portanto, o ônus da prova a seu favor. ${ }^{316}$

A importância da utilização das máximas de experiência também como diretriz na atribuição dinâmica do ônus da prova se mostra portanto perceptível ${ }^{317}$, justificando-se ainda mais no processo do trabalho vez que juízo especializado, o que, nas palavras de Manoel Antonio Teixeira Filho, "possibilita, sem dúvida, uma efetiva observação dos fatos que ordinariamente acontecem nos sucessivos casos que lhe são submetidos ao conhecimento, por intermédio das ações aforadas." 318

Diante o juiz do trabalho de situações já conhecidas pelas regras de experiência de sua atividade profissional bem assim do acúmulo de conhecimentos culturais,

\footnotetext{
${ }^{315}$ Art. 335 do CPC: "Em falta de normas jurídicas particulares, o juiz aplicará as regras de experiência comum subministradas pela observação do que ordinariamente acontece e ainda as regras da experiência técnica, ressalvado, quanto a esta, o exame pericial."

${ }^{316}$ VIANA, Márcio Túlio. op. cit, p.1222.

${ }^{317}$ Cambi a respeito da teoria dinâmica do ônus da prova leciona que "referida teoria reforça o senso comum e as máximas da experiência ao reconhecer que quem deve provar é quem está em melhores condições de demonstrar o fato controvertido, evitando que uma das partes se mantenha inerte na relação processual porque a dificuldade da prova a beneficia. Portanto, a distribuição do ônus (ou da carga) da prova se dá de forma dinâmica, posto que não está atrelada a pressupostos prévios e abstratos, desprezando regras estáticas, para considerar a dinâmica fática, axiológica e normativa - presente no caso concreto, a ser explorada pelos operadores jurídicos (interpretes)" In. A prova civil: admissibilidade e relevância. São Paulo: Revista dos Tribunais, 2006, p.342

318 TEIXEIRA FILHO, Manoel Antonio. A prova no processo do trabalho. Sao Paulo: Ltr, 2003, p.109
} 
deverá relativizar o ônus da prova reduzindo o seu peso em prol da parte a quem aproveite a presunção de veracidade dos fatos alegados. O juiz também deve agir como pessoa comum ao longo da instrução formando sua convicção e "concluindo pela existência do fato quando a sua consciência tiver por bem mais provável a existência do que a inexistência". 319

Por fim, e ainda invocando as lições de Dinamarco "seja no processo das pequenas causas ou no comum, está institucionalizado o valor das máximas de experiência, às quais é lícito ao juiz recorrer para justificar sua convicção, "sempre com a preocupação de fazer justiça e evitar que a rigidez de métodos preestabelecidos o conduza a solução que contrarie a grande premissa... de que o processo é um instrumento sensivelmente ético e não friamente técnico",320

$\mathrm{Na}$ perspectiva, portanto, da instrumentalidade do processo, as regras estáticas do ônus da prova não podem inviabilizar a tutela do direito substancial, de modo que o magistrado mesmo a par da existência de norma específica deve, a partir de máximas de experiência, que criam presunções sejam jurisprudenciais sejam legal, alterar o ônus da prova com o objetivo exato de promoção da efetividade daquele direito e da própria justiça da decisão. ${ }^{321}$

As presunções judiciais, que emanam das regras de experiência, e as presunções legais tem ainda a função prática de atuar na distribuição do ônus da prova inclusive como verdadeiras regras de conduta aos litigantes. De fato tanto as partes quanto o juiz realizam atividade de valoração da prova embora em contextos e com resultados diversos e desta forma, por exemplo, a parte sabedora da circunstância de que uma presunção existente a beneficia ou prejudica, pautará sua conduta a partir dessa noção. ${ }^{322}$

\footnotetext{
${ }^{319}$ DINAMARCO, Cândido Rangel. A instrumentalidade do Processo. São Paulo: Malheiros, 1993, p.254.

${ }^{320}$ Idem.Ibidem. Op.cit. p.254.

321 CAMBI, Eduardo Augusto Salomão. A prova civil: admissibilidade e relevância. São Paulo: Revista dos Tribunais, 2006, p.335.

${ }^{322}$ Flávio Yarshell explica a questão: "De forma coerente com esse raciocínio, mesmo quando se pensa nas presunções judiciais - resultantes das máximas de experiência - não se pode descarta a influência que as mesmas
} 
Em síntese, situações haverá em que, pelas regras estáticas originariamente o ônus da prova seria do trabalhador, mas o juiz baseado em máximas de sua experiência, deverá atribuir o ônus da prova ao réu, equalizando, desta forma, as partes no conflito processual $^{323}$.

Por fim outro substrato apto a justificar a atribuição do ônus da prova e, de certa maneira, por vezes determinado pelas regras de experiência e presunções, diz respeito à verossimilhança. Em rigor, a primeira busca do magistrado é pela convicção da verdade, mas situações particulares do direito substancial acabam por exigir a redução, pelo juiz, quanto às exigências de prova, passando a se contentar com uma convicção de verossimilhança. ${ }^{324}$ Em sendo assim, mesmo que, por exemplo, o autor possa produzir a prova, não há que exigi-la de forma absoluta, contentando-se o magistrado, com a verossimilhança das alegações e a partir dela utilizar a distribuição do encargo da prova de modo a alcançar a efetividade da prestação jurisdicional.

tenham, ou que possam ter, sobre a conduta das partes no processo ou, mais uma vez, antes dele. Ainda que as ilações extraídas pelo magistrado a partir da ocorrência de certos fatos (para concluir que outros aconteceram) se restrinjam ao caso concreto, $\mathrm{d}$ ando origem a verdadeiras regras "juridicizadas", não raro aquelas resultam do alinhamento a ouras fixadas em precedentes pelos tribunais; as quais, por seu turno, podem resultar em orientações jurisprudenciais, que podem e devem ser levadas em conta pelos interessados (no processo ou antes mesmo dele). YARSHELL, Flávio Luiz. Antecipação da Prova sem o requisito da urgência e o Direito Autônomo à Prova. São Paulo: Malheiros, 2009, pp.67-68

323 Aqui há que se pensar nas seguintes hipóteses exemplificativas: 1) Empregado doméstico que postula pagamento de salário e o réu, empregador, não detém esses documentos comprobatórios: ainda assim, pela máxima da experiência, segundo a qual não se trabalharia sem pagamento de salários por longo período e consideradas as peculiaridades do trabalho doméstico, retira-se do réu o peso da carga probatória; 2) empregado que postula responsabilização subsidiária da tomadora de serviços e esta, não negando o contrato com a empresa prestadora, afirma que o trabalhador não lhe prestou serviços: pelo que comumente acontece os empregados das empresas prestadoras exercem seu mister nas tomadoras, não se tratando da hipótese normal de negativa de prestação de serviços; assim, há que se diminuir o peso do autor em provar a prestação de serviços na tomadora, a qual detém inclusive aptidão da prova positiva, ou seja, quais eram as pessoas, então, que trabalhavam em suas unidades,não sendo crível, pelas máximas de experiência, que as empresas não controlem o acesso de pessoas à sua propriedade privada. 


\subsubsection{O princípio da proteção e o ônus dinâmico da prova}

Partindo de uma idéia de Machado $\mathrm{Jr}^{325}$, Márcio Túlio Viana ${ }^{326}$ propõe como critério para inversão do ônus da prova no processo do trabalho que aquela ocorra sempre que aplicação clássica das regras distributivas possa colidir com os princípios informadores do direito material do trabalho. Aponta o autor como exemplo a própria Súmula $212^{327}$ do TST que expressa justamente o princípio da continuidade da prestação laboral.

$\mathrm{Na}$ concepção atual do processo como um todo não restam dúvidas de que este sofre os influxos do direito material que instrumentaliza. Assim os reflexos dos princípios de direito de trabalho enquanto normas axiológicas vão se fazer sentir no direito processual do trabalho na questão relativa à distribuição do ônus da prova muito mais pelo viés das presunções a que dão azo em matéria substantiva e estas sim na definição da atribuição do ônus da prova. Acredito, portanto, que no geral a influência dos princípios gerais de direito do trabalho, ainda que incontestável, se configure mais de uma forma indireta, gerando as presunções favoráveis ao trabalhador.

Nem se conteste a influência dos princípios de direito material em matéria de ônus da prova e sua distribuição, pois essas normas processuais tem uma natureza dúplice (processual e material), o que autorizaria a ingerência do próprio direito material sobre elas, especialmente os princípios gerais de direito do trabalho.

\footnotetext{
${ }^{324}$ MARINONI, Luiz Guilherme; ARENHART, Sérgio Cruz.Prova. São Paulo: Ed.Revisa dos Tribunais, 2010, p.189.

${ }^{325}$ César Pereira da Silva Machado Júnior como visto no Capítulo 2 propõe a observação dos princípios gerais de direito do trabalho como critérios a observar para a distribuição do ônus da prova, quais sejam, princípio da proteção, da irrenunciabilidade de direitos, princípio da continuidade da relação de emprego, princípio da primazia da realidade, da razoabilidade e da boa-fé. In O ônus da prova no processo do trabalho. São Paulo: Ltr, 2001

${ }^{326}$ VIANA, Márcio Túlio. op. cit. p. 1224.

${ }^{327}$ SUM-212 DESPEDIMENTO. ÔNUS DA PROVA (mantida) - Res. 121/2003, DJ 19, 20 e 21.11.2003.O ônus de provar o término do contrato de trabalho, quando negados a prestação de serviço e o despedimento, é do empregador, pois o princípio da continuidade da relação de emprego constitui presunção favorável ao empregado.
} 
A propósito Dinamarco reconhecendo explicitamente momentos de intersecção entre o plano material e processual na ordem jurídica, relaciona alguns institutos chave que sofrem o influxo do direito material, denominando-os de institutos processuais substanciais, dentre eles o ônus da prova. Impossível trazer a idéia do autor sem transcrevê-la:

\begin{abstract}
"Quando, porém se passa das especulações abstratas para observação das concretas situações de conflitos entre indivíduos ou grupos (crises jurídicas), percebe-se uma proximidade muito significativa entre certos institutos francamente processuais e a situação de direito substancial em relação à qual o processo atuou ou deve atuar. Esses institutos - ação, competência, fontes e ônus da prova, coisa julgada e responsabilidade patrimonial - são responsáveis por situações que se configuram fora do processo e dizem respeito diretamente à vida das pessoas em sociedade, nas suas relações com as outras ou com os bens que lhes são úteis ou desejados; e só num segundo momento eles são objeto das técnicas do processo, a saber, quando um processo se instaura e então se pensa nas atividades a serem desenvolvidas para sua atuação.

A ação, a competência a prova, a coisa julgada e a responsabilidade patrimonial, recebendo do direito processual parte de sua disciplina (na sua técnica), mas também dizendo respeito à situação dos sujeitos fora do processo (às vezes, até antes dele), compõem um setor a que a doutrina já denominou direito processual material (Chiovenda). Essas são, portanto, institutos bifrontes: só no processo aparecem de modo explícito em casos concretos, mas são integrados por um intenso coeficiente de elementos definidos pelo direito material e - o que é mais importante - de algum modo dizem respeito à própria vida dos sujeitos e suas relações entre si e com os bens da vida. Constituem pontes de passagem entre o direito e o processo, ou seja, entre o plano substancial e o processual no ordenamento jurídico (Calamandrei). ${ }^{328}$ (negritei)
\end{abstract}

Assim a própria forma de atribuição dinâmica do ônus da prova como categoria bifronte há de ser analisada em função da índole do direito material posto em discussão frente ao órgão jurisdicional dando-lhe proeminência inclusive, repita-se, quanto à aplicabilidade dos princípios de direito substancial do trabalho. ${ }^{329}$

${ }^{328}$ DINAMARCO, Cândido Rangel. Instituições de Direito Processual Civil. Vol.1 São Paulo: Malheiros, 2003, p.44. Continua o autor especificamente: "A prova, por exemplo. É no processo que se desenvolve toda sua dinâmica e é nele que produzirá sua eficácia institucionalizada. Mas as fontes de prova, ou seja, as pessoas e coisa capazes de fornecer informações ao juiz que julgará, são elementos externos ao processo, fazem parte da vida comum e apenas em um sentido tempo serão trazidas a ele e utilizadas como meios instrumentais. Em seu aspecto estático, as fontes de prova residem no direito substancial. Daí sua configuração bifronte e a necessidade de a categoria jurídica prova ser encarada com a consciência de que as fontes de prova vêm para o processo carregadas de conotações relacionadas como próprio conflito a que se referem" pp.43-44.

329 Roland Arazi reconhece expressamente a necessidade dessa adequação das normas de distribuição do ônus da prova ao caso concreto ao se manifestar com base na jurisprudência que "las reglas atinentes a la carga de la prueba deben ser apreciadas em función de la índole y características del asunto sometido a la decisión del órgano jurisdiccional, principio este que se encuentra en relación com la necesidade de dar primacía - por 
Escapa à pretensão deste trabalho dissertar sobre todos os princípios do Direito do Trabalho ante sua magnitude. Logo no âmbito da fundamentação quanto aos pressupostos para a dinamização do ônus da prova, vamos nos limitar à análise do princípio da proteção (princípio vetor), dada a controvérsia que tem gerado sob seu aspecto do "in dubio pro misero" e sua aplicabilidade em matéria de ônus da prova.

As funções dos princípios são basicamente a informativa, inspirando o legislador; a normativa porque atuam subsidiariamente na ausência de lei, integrando o direito como um todo e a interpretativa, vez que constituem um critério orientador para o intérprete. ${ }^{330}$ Interessa no caso especialmente a função interpretativa porque assinala o caminho que deve seguir aplicador das normas trabalhistas, inclusive as processuais.

O Direito do Trabalho tem como traço característico que permeia a sua própria formação histórica a necessidade de promoção do equilíbrio entre os fatores da produção, buscando o nivelamento da desigualdade real entre trabalhadores e empregadores. Para tanto foram sendo traçadas regras e princípios de direito do trabalho a fim de proteger o trabalhador frente a possíveis abusos do empregador.

Contemporaneamente há quem reconheça mesmo como princípio de direito processual do trabalho um "princípio da unidade essencial entre o direito processual do trabalho e o direito do trabalho". De fato, leciona Cléber Lúcio de Almeida que a finalidade primeira do processo do trabalho é justamente proteger a dignidade humana, fundamento da própria República Federativa do Brasil, e na medida em que realizar concretamente o direito material o processo judicial ganha força e valor. Deste modo não se podem olvidar no processo das especificidades do direito material do trabalho "que por meio dele deve ser atuado, sob pena de se operar um verdadeiro defeito de proteção (ausência de medidas aptas e

sobre la interpretación de las normas procesales - a la verdad jurídica objetiva, de modo que su esclarecimiento no se vea perturbado por um excesivo rigor formal" ARAZI, Roland. La prueba en el proceso civil. $2^{\mathrm{a}}$ edição. Buenos Aires: Ediciones La Rocca, 1998, p.106.

330 PLÁ ROGRIGUEZ, Américo. Princípios de Direito do Trabalho. São Paulo: LTr, 2002, p.43 
adequadas pra tornar concretas as situações de vantagem que o legislador instituiu em favor do trabalhador)", 331

Continua o mesmo autor precisamente asseverando que:

"Sendo assim, não se pode esquecer que o aviltamento da dignidade humana, resultante das precárias condições a que era submetido o trabalhador em determinado contexto social, fez surgir, como reação, o Direito do Trabalho. O Direito do Trabalho persegue o equilíbrio e a justiça nas relações de trabalho, em favor da dignidade humana do trabalhador. Em sua gênese e essência, portanto, o Direito do Trabalho é um direito humanizante, por ser resultado da reação à submissão do trabalhador a condições indignas de trabalho, ditadas pelo fato de as novas estruturas de produção e o capital terem se tornado, com a formação da sociedade industrial, no novo poder, como acentua o Papa Bento XVI na Carta Encíclica Deus Caritas Est. Por servir, essencialmente, à concretização do Direito do Trabalho, o Direito Processual do Trabalho deve ser também um direito humanizante, no sentido de ter a tutelada da pessoa humana como fundamento e finalidade." 332 (g.n.).

Nesse diapasão Plá Rodriguez ensina que o princípio da proteção se refere a esse critério fundamental que orienta o Direito do Trabalho na busca da concretização do objetivo de amparar preferencialmente o trabalhador. ${ }^{333}$

O princípio protetor no âmbito do direito material do trabalho subdivide-se no da aplicação da regra mais favorável, principio in dubio pro operario e por último no da conservação da condição de trabalho mais favorável. O segundo, também denominado princípio do in dubio pro misero determina o critério segundo o qual, no caso da suscetibilidade de interpretação de uma norma de vários modos, deva ser dada preferência à interpretação mais favorável ao trabalhador. ${ }^{334}$

331 ALMEIDA, Cleber Lúcio. Princípios de Direito Processual do Trabalho e o Exame dos Reflexos das Recentes Alterações do Código de Processo Civil no Direito Processual do Trabalho. In: CHAVES, Luciano Athayde (org.) Direito Processual do Trabalho: Reforma e Efetividade. São Paulo: LTr, 2007, pp.18-19.

${ }^{332}$ Idem. Ibidem, p. 19

333 PLÁ ROGRIGUEZ, Américo op.cit. p. 81

334 Idem. Ibidem, p.107 
Interessa sobremaneira até mesmo em razão da intrincada polêmica, questionar a projeção do principio protetivo, sob o aspecto do "in dubio pro misero", do âmbito material para o processual do trabalho em matéria de ônus da prova.

A doutrina não se mostra pacífica quanto a tal possibilidade com relação à prova. Aqueles que contrariam a aplicação afirmam que os fatos devem chegar ao juiz como se sucederam, vinculando-se o magistrado tão-só às provas produzidas nos autos e no caso de dúvida, julgando conforme a regra do ônus da prova. Por seu turno os defensores da aplicabilidade entendem que não havendo prova conclusiva sobre o fato, apenas indícios, o magistrado deve valorá-los a favor do empregado. Para estes últimos, considerado o princípio em questão quando da valoração da prova o juiz deve observar as diferenças existentes entre as partes (diferenças econômicas, técnicas, etc)

Maurício Godinho Delgado critica a aplicação do princípio no campo processual, afirmando que haveria um desequilíbrio atávico durante o processo de exame e valoração dos fatos trazidos à análise, o que não passaria pelo crivo científico sob o qual se estuda hoje o fenômeno jurídico. Para o autor a teoria do ônus da prova própria do direito processual do trabalho e também as inúmeras presunções que beneficiam o empregado já dão possibilidades mais eficazes de reprodução, no processo, da verdade real, instaurando portanto um desequilíbrio de ônus probatório em prol do trabalhador. Assim, deve-se julgar contra a parte com o encargo da prova no tópico duvidoso, não se podendo utilizar a diretriz genérica in dubio pro operario. ${ }^{335}$

Entretanto o vértice pelo qual há que ser visto o princípio do in dubio pro operario encontra-se limitado exatamente no que tange à possibilidade de sua incidência sobre a distribuição do ônus da prova.

Não há dúvida de que o direito do trabalho e todas suas normas tem uma finalidade protetora que decorreu justamente da necessidade de intervenção do Estado para 
impor condições míninas de trabalho e portanto da necessidade de proteger o hipossuficiente econômico. E para que o direito material do trabalho se torne efetivo através do direito processual do trabalho há que se admitir esse influxo principiológico do direito material.

Para compreensão dessa possibilidade impõe-se diferenciar aqui a questão da valoração da prova no momento do julgamento (e neste ponto de fato tem razão os críticos da utilização do in dubio pro misero para o "desempate" em matéria de prova), do primeiro momento de atribuição do ônus da prova dinâmico, que seria, a priori, o da instrução. Pensando-se no ônus dinâmico como uma regra de procedimento, seria plausível, senão recomendável que em determinadas hipóteses o juiz ao analisar o decurso da instrução, calcado no princípio da proteção, na sua subespécie do in dubio pro operario informasse a parte (que originalmente pelas regras clássicas não teria esse encargo) que deveria realizar a prova deste ou daquele fato, justificando sua decisão e oportunizando, portanto, a participação daquele agora imputado com o ônus.

Amauri Mascaro do Nascimento responde afirmativamente à aplicabilidade do princípio protecionista do direito do trabalho ao direito processual, apontando inclusive a hipótese específica do ônus da prova, que seria mais acentuado para o empregador. ${ }^{336}$

Se o próprio direito do trabalho foi elaborado com o propósito de proteção ao litigante menos poderoso, a força do princípio protecionista há que se operar tanto no direito substantivo quanto no processual diante do escopo comum de realização de justiça social. Há inclusive regras processuais que sofrem a incidência da proteção a exemplo daquela prevista no art.844 da CLT.

Márcio Túlio Viana aponta expressamente o princípio em questão como critério balizador da inversão do ônus da prova, e com apoio em outros doutrinadores parece adotar a perspectiva da aplicação em caso de dúvida ou divisão da prova. Situa, entretanto, os

\footnotetext{
${ }^{335}$ DELGADO, Maurício Godinho. Curso de Direito do Trabalho. São Paulo: LTr, 2003. pp.211-212

${ }^{336}$ NASCIMENTO, Amauri Mascaro do. Curso de Direito Processual do Trabalho. São Paulo: Saraiva, 1994. p.56
} 
limites da aplicabilidade ao afirmar que sua incidência "dependeria de um começo de prova em favor do empregado, embora insuficiente para lhe dar a vitória, caso incidissem as regras usuais". 337

Manoel Antonio Teixeira Filho chega a pretender a utilização desse princípio como critério para superação da desigualdade do trabalhador em matéria probatória, reconhecendo entretanto que a aplicação do in dubio pro misero para exame e valoração da prova não é legalmente possível. ${ }^{338}$

Sérgio Pinto Martins ao tratar, desta feita sob a perspectiva não mais dos princípios de direito material, mas sim dos princípios de processo do trabalho tem uma abordagem precisa acerca justamente do aspecto instrumental da questão. Afirma o autor que:

“o verdadeiro princípio do processo do trabalho é o protecionista. Assim como no Direito do Trabalho as regras são interpretadas mais favoravelmente ao empregado, em caso de dúvida, no processo do trabalho também vale o princípio protecionista, porém analisado sob o aspecto do direito instrumental.

(...) O processo do trabalho visa, segundo Galart Folch, assegurar superioridade jurídica ao empregado em face de sua inferioridade econômica. O processo é que irá adaptar-se à natureza da lide trabalhista. $\mathrm{O}$ empregador sempre tem melhores meios de conseguir mais facilmente sua prova, escolhendo testemunhas entre seus subordinados, podendo suportar economicamente a demora na solução do processo. Já o empregado não tem essa facilidade ao ter que convidar a testemunha e não saber se esta comparecerá, com medo de represálias do empregador, e, muitas vezes, de não ter prova a produzir por esses motivos." 339 (negritei) ${ }^{340}$

Desta forma, visto o princípio da proteção sob essa perspectiva instrumental, acredito que o princípio in dubio pro operario não seja aplicável no aspecto

\footnotetext{
${ }^{337}$ Op.cit. p. 1222

${ }^{338}$ TEIXEIRA FILHO, Manoel Antonio. Curso de Direito Processual do trabalho. São Paulo: LTr, 2009, p.97

${ }^{339}$ MARTINS, Sérgio Pinto. Direito processual do trabalho. São Paulo: Atlas, 2000, p.63

340 Também Mauro Schiavi ao tratar dos princípios processuais refere-se a um protecionismo temperado ao trabalhador, que não seria o mesmo princípio do direito material, mas "sim uma intensidade protetiva, vista sob o aspecto instrumental ao trabalhador a fim de lhe assegurar algumas prerrogativas processuais para compensar eventuais entraves que enfrenta ao procurar a Justiça do trabalho, devido à sua hipossuficiência econômica $\mathrm{e}$ também de informação e, muitas vezes, da dificuldade em provar suas alegações, pois, via de regra os documentos da relação de emprego ficam na posse do empregador" In Manual de direito Processual do Trabalho. São Paulo: LTr 2009. pp. 90-97
} 
referente à valoração da prova. Trata-se, isto sim, de princípio norteador justamente na interpretação das regras processuais, transpostas que serão não no campo da valoração da prova, mas num momento anterior, ou seja na interpretação das regras do ônus da prova enquanto regras de procedimento, utilizando-se o princípio como fundamento para exigir da parte a produção de determinada prova ${ }^{341}$. Não há se falar, pois em "desempate" da prova, mas numa interpretação de regras processuais a favor do trabalhador, ou seja, na distribuição do encargo da prova como técnica concretizadora também do princípio da proteção. Aqui repita-se, não se trata de pressuposto isolado para distribuição dinâmica, mas sim uma diretriz a mais a facilitar o trabalho do intérprete aplicando-se as regras processuais a seu favor. Funciona, em síntese, o in dubio pro misero como outra diretriz a abalizar a atribuição da carga dinâmica.

Diretriz com base legal pois na medida em que já definimos que regras sobre prova tem natureza dúplice, se sujeitam aos princípios também do direito material e a CLT em seu art. $8^{\circ}$ é expressa ao autorizar decisões por outros "princípios e normas gerais de direito, principalmente do direito do trabalho".

Ressalvo por fim a ausência da abordagem sob o ângulo da aplicação da carga probatória dinâmica a partir dos princípios do processo do trabalho eis que o enfoque principal na questão processual se deu a partir dos próprios princípios constitucionais, sendo certo que os princípios processuais ordinários, com a própria evolução do processo civil não se encontram mais tão antagônicos com os do processo do trabalho.

\subsubsection{Diretriz da Lealdade, boa-fé e cooperação da partes}

Outra ordem de fundamentação para aplicação da teoria dinâmica do ônus da prova, já apresentada também no capítulo primeiro, repousa numa concepção ético-jurídica deduzida da própria legislação em vigor, na medida em que o art. 14, I do Código de Processo

\footnotetext{
${ }^{341}$ Nesse sentido também: SOUZA, Fabiano Coelho de. O princípio da pré-constituição das provas no processo do trabalho. Revista Trabalhista Direito e Processo. São Paulo, no. 31 - outubro, 2009, p.154.
} 
Civil determina que as partes devem reportar a verdade, bem assim o inciso II do mesmo dispositivo determina a atuação com lealdade e boa-fé, no decorrer de uma relação jurídicoprocessual travada. Nem nos olvidemos das próprias disposições processuais que determinam ao autor na inicial indicar as provas com o que pretende demonstrar a verdade dos fatos e aquelas que impõem ao réu alegar toda a matéria de defesa expondo as suas razões de fato e especificando as provas que pretende produzir. Por fim dispõe o art.339 do CPC ${ }^{342}$ que "ninguém se exime do dever de colaborar com o Poder Judiciário para o descobrimento da verdade".

E são justamente aqueles deveres de lealdade e cooperação ${ }^{343}$ das partes no processo que representam a segunda ordem de fundamentação a que faz menção Danilo Knijnik $^{344}$ e revelam a obrigação que tem as partes de atuar no processo com lealdade, probidade e boa-fé, colaborando, inclusive para revelar a verdade dos fatos e cooperar com o órgão jurisdicional na busca de uma sentença justa. ${ }^{345}$ Nesse sentido também Alexandre

342 Ísis de Almeida a propósito do art.339 do CPC a fundamentar seu entendimento no sentido da relevância da distinção entre ônus e dever para creditar que o ônus da prova seria “ 'dever' mesmo para com o Estado, pois se trata de direito público, e não de obrigações entre as partes, decorrentes de um pacto". Continua o autor trazendo o destaque do dever na exposição de motivos do projeto de lei que criou o Código:" Posto que o processo civil seja, de sua índole, eminentemente dialético, é reprovável que as partes se sirvam dele, faltando ao dever da verdade, agindo com deslealdade e empregando artifícios fraudulentos; porque tal conduta não se compadece com a dignidade de uma instrumento que o Estado põe à disposição dos contendores para atuação do direito e realização da justiça. In. Manual de Direito Processual do Trabalho. $2^{\circ}$.vol. São Paulo: LTr, 1997, p.125

${ }^{343}$ Vislumbrando essa ordem de fundamentação para aplicação da dinamização do ônus da prova relativamente ao dever de cooperação assim se expressa Daniel Mitidiero e partindo da perspectiva do ônus da prova em sua dupla dimensão, "e como o fito de bem atender-se a determinada situações da vida no processo, a doutrina tem aluído à possibilidade de dinamizar o ônus da prova, fundamento a partir do caso concreto a repartição do encargo probatório. Esse expediente embora perigosíssimo quando manejado de maneira inadequada, encontra-se em total consonância com a idéia de processo civil pautado pela colaboração, pressupondo mesmo para sua aplicação um modelo de processo civil cooperativo. Seu fundamento está na necessidade de velar-se por uma efetiva igualdade entre as partes no processo e por um escorreita observação dos deveres de cooperação nos domínios do direito processual civil, notadamente do dever de auxílio do órgão jurisdicional para com as partes" MITIDIERO, Daniel. Bases para construção de um processo civil cooperativo: o direito processual civil no marco teórico do formalismo valorativo. Tese (Doutorado), Faculdade de Direito, Universidade Federal do Rio Grande do Sul, 2007, p. 93

${ }^{344}$ KNIJNIK, Danilo. Ob.cit, p.945

345 AIRASCA, Ivana María. "Reflexiones sobre la doctrina de las Cargas Probatorias Dinámicas. In.: PEYRANO, Jorge W.(dir.); LÉPORI WHITE, Inês (coord.). Cargas probatorias dinámicas. Buenos Aires: Rubinzal-Culzoni, 2004, p.141 
Câmara vê a distribuição dinâmica do ônus da prova como decorrência do princípio da colaboração, solidariedade e boa-fé ${ }^{346}$.

Desta forma a adoção do ônus dinâmico da prova decorre da aplicação desse princípio da cooperação, que juntamente com o princípio da solidariedade se mostram como manifestações do princípio da boa-fé.

A propósito do dever de cooperação Arthur Carpes bem lembra que "a partir da compreensão de que o processo constitui um instrumento para a tutela dos direitos fundamentais, ganha relevo não apenas a atividade e responsabilidade do juiz, mas também a atividade e responsabilidade da pares, a fim de que a justiça - finalidade primordial do processo - seja alcançada. Consagrado do direito fundamental à tutela jurisdicional adequada e efetiva, exige-se do juiz um esforço ainda maior na tarefa de formação do juízo de fato, na medida em que somente dessa forma será possível alcançar a justiça Tal esforço, todavia, é compartilhado com as partes, às quais também é endereçado semelhante dever de cooperação. Afinal, se o processo cumpre função pública de pacificar com justiça, constitui dever de todos os sujeitos processuais, bem como de terceiros, eventualmente, colaborar para que tais finalidades sejam atingidas. ${ }^{347}$

Importante lição vem ainda do direito português que prevê expressamente que o dever de cooperação das partes estende-se à área da prova. Ensina Miguel Teixeira de Souza que no Código de Processo Civil (art.519, no. 1) há previsão específica no sentido de que as pessoas que sejam ou não parte na causa, têm o dever de prestar a sua colaboração para a descoberta da verdade, independentemente do ônus da prova, ou seja, vincula mesmo a parte que não está onerada com a prova. ${ }^{348}$

\footnotetext{
${ }^{346}$ CÂMARA, Alexandre Freitas. Doenças Preexistentes e ônus da prova: o Problema da Prova Diabólica e uma possível solução". Revista Dialética de Direito Processual. São Paulo: Dialética, 2005, n.31, p.15

${ }^{347}$ CARPES, Artur Thompsen. Op.cit.p.62

${ }^{348}$ SOUSA, Miguel Teixeira de. Aspectos do novo processo civil português. Revista Forense. Rio de Janeiro, v.338, abr./jun.1997 ., p.149
} 
De fato, hoje o processo judicial se apresenta com uma dimensão social em que o protagonismo das partes transcende seus interesses e a própria autonomia da vontade, impondo um dever de cooperação que privilegia a solidariedade e boa-fé processuais, exigências atuais da própria finalidade da jurisdição com foco na prestação jurisdicional eficiente e justa. $^{349}$

\section{Alguns aspectos procedimentais}

\subsection{Regra dinâmica do ônus da prova - regra excepcional}

Um primeiro aspecto a ponderar diz respeito à aplicabilidade do ônus da prova como regra excepcional ${ }^{350}$. A tendência dos intérpretes, a vista da própria previsão do anteprojeto do novo código de processo civil ${ }^{351}$ passa pelo entendimento de que a regra do ônus dinâmico da prova atuará numa ordem excepcional, inclusive não deslocando todos os fatos a provar de uma parte a outra (o que representa uma diferença em relação ao instituto da inversão do onus probandi).

Vale também para a dinamização do ônus da prova a observação de Jorge Luiz Souto Maior quanto à própria técnica de inversão do encargo probatório no sentido de que

\footnotetext{
"Essa teoria, no entanto, como se disse, não elimina a regra básica de que ao autor - reclamante - cabe a prova do fato constitutivo de seu direito, e ao réu reclamado - a prova dos fatos impeditivos, modificativos e extintivos do direito do autor, sem perder de vista, é claro, a possibilidade de o juiz, em casos específicos, seguindo o teor do art.6 $6^{\circ}$., VIII, do Código de Defesa do Consumidor, inverter o ônus da prova, mas fazendo isso, expressamente, no momento de saneamento do processo trabalhista que é a audiência inicial,em respeito à isonomia processual,
}

\footnotetext{
${ }^{349}$ MORELLO, Augusto Mario. La prueba: tendencias modernas. Buenos Aires: Abeledo-Perrot, 1991, pp.61-64

${ }^{350}$ Para Robson Renault Godinho trata-se de teoria excepcional e residual que imprescinde de cuidadosa fundamentação e ciência aos sujeitos envolvidos. In A distribuição do ônus da prova na perspectiva dos direitos fundamentais. Revista da EMERJ. Rio de Janeiro, v. 10, n. 38, p. 263-84, abr./jun. 2007, p.280

351 Art. 262, caput. Considerando as circunstâncias da causa e as peculiaridades do fato a ser provado, o juiz poderá, em decisão fundamentada, observado o contraditório, distribuir de modo diverso o ônus da prova, impondo-o à parte que estiver em melhores condições de produzi-la. $\S 2^{\circ} \mathbf{A}$ inversão do ônus da prova, determinada expressamente por decisão judicial, não implica alteração das regras referentes aos encargos da respectiva produção.(grifei)
} 
ou ainda, após o depoimento pessoal das partes que lhe pode dar forte impressão sobre a verossimilhança da alegações. Assim, juntadas as provas documentais, desde que racionalmente elaboradas, caberá ao reclamante prova os fatos constitutivos de seu direito, quando o juiz não os considere, por si só, verossímeis, tendo à vista as regras de experiência, e ao reclamado, se for o caso, os fatos impeditivos, modificativos e extintivos do direito do reclamante." ${ }^{, 352}$

Não estariam, portanto, a princípio eliminadas as regras do art.333, I do CPC e do próprio art.818 da CLT. Haveria, isto sim, duas ordens de condicionantes ${ }^{353}$ a legitimar a superação das regras clássicas. O primeiro condicionamento é de ordem material e implica na demonstração da inadequação das regras estáticas para resolução daquele caso sob a perspectiva do alcance da justiça ao caso concreto, apurando-se, ainda se a outra parte detentora do ônus original está em posição privilegiada, ou seja, com maior facilidade ou aptidão para a prova. Sob a perspectiva desse condicionamento material a legitimação da atribuição dinâmica ônus da prova terá que se calcar nos pressupostos já analisados.

Como condições processuais de legitimação da teoria, para sua aplicabilidade enquanto técnica procedimental haveria duas outras discussões cruciais, a saber, a fundamentação da própria decisão que atribui o ônus na forma dinâmica e a oportunidade da prova à parte a quem lhe será imposto o encargo. ${ }^{354}$

352 SOUTO MAIOR, Jorge Luiz. A efetividade do processo. In: CORREIA, Marcus Orione Gonçalves (org.). Curso de direito do trabalho: vol. 4 - Direito processual do trabalho. São Paulo: LTr, 2009, p. 77

353 Conforme Daniel Mitidiero In. Bases para construção de um processo civil cooperativo: o direito processual civil no marco teórico do formalismo valorativo. Tese (Doutorado), Faculdade de Direito, Universidade Federal do Rio Grande do Sul, 2007, pp.94-95

${ }^{354}$ Acerca da necessidade de motivação das decisões para que se legitimem também perante a sociedade bem se expressou Carlos Alberto Álvaro de Oliveira ao concluir que: "pode-se afirmar que o sistema brasileiro dispõe de meios suficientes para vencer o formalismo pernicioso e conduzir o processo a suas reais metas. Mostra-se necessária, tão-somente, uma atitude mais aberta, talvez uma mudança de mentalidade, para o enfrentamento de problemas dessa ordem. Advirta-se, no entanto, que o juiz não pode ser arbitrário e desprezar o formalismo virtuoso, a seu bel prazer. Por isso mesmo, a solução da situação problemática, gerada pela antinomia entre a justiça e o formalismo concreto encontra encaminhamento e solução apenas dentro do discurso jurídico, proferido este com a linguagem que lhe é própria. Não se esqueça que a apreensão hermenêutica da realidade, inclusive a jurídica, só é possível porque o sujeito cognoscente conhece de antemão a linguagem em jogo e o alcance da instrumentação nela empregada . E o discurso jurídico só obriga até onde conduza a sua força de intrínseca persuasão, força vinculante que há de assentar no sistema jurídico (constitucional e infraconstitucional), nas valorações e princípios dele emanantes, e nas valorações sociais e culturais dominantes no seio da coletividade, enfim no direito como totalidade, para que tudo não redunde a final em puro arbítrio . Nesse difícil, mas necessário equilíbrio, em que exerce papel fundamental o dever de motivação adequada do ato judicial, habita a força e a legitimação da justiça perante a sociedade civil. (g.n.). O Formalismo-Valorativo no 
Jorge Souto Maior a propósito da técnica de inversão do ônus da prova afirma ser importante "que o juiz, em decisão sempre fundamentada, explicite a inversão, como critério de julgamento, para que as partes possam participar da instrução, produzindo as provas que se farão importantes para o convencimento do juiz" 355

Ao contrário do que ocorre com a regra estática de distribuição do ônus da prova, na sua relativização, ou seja, na sua distribuição dinâmica, a exemplo da própria hipótese de inversão, a decisão que a determina tem natureza interlocutória, não se tratando, naquele momento de regra de julgamento. Desta forma, e na contemporânea compreensão do processo colaborativo, há que ser esclarecido no momento da atribuição do ônus de forma diferenciada a quem caberá realizar a prova fundamentadamente. O contraditório como entendido hoje imprescinde também dessa ciência prévia de modo a garantir a participação no procedimento em iguais condições pelas partes. Registre-se que a própria legitimação dessa ampla possibilidade de poder ao juiz vem da conferência às partes do direito de serem ouvidas e participarem desse instrumento.

Tratando-se de um ônus processual atribuído pelo Juiz por decisão interlocutória devidamente fundamentada, prolatada tão-somente após a observância do pressuposto lógico-jurídico necessário da oitiva dos sujeitos, em observância ao contraditório, ainda durante a instrução (regra de procedimento), tem-se que o sujeito que ao final não se desincumbir de tal ônus sofrerá as conseqüências dessa inércia nessa segunda dimensão da regra do ônus da prova (ônus da prova como regra de julgamento).

Nesse sentido também a lição de Flávio Yarshell ao asseverar que nem a visão do ônus da prova como "cargas dinâmicas" altera a obrigatoriedade de participação das partes em seus encargos probatórios vez que a avaliação quanto à maior facilidade de acesso e

confronto com $\quad$ o $\quad$ formalismo $\quad$ excessivo $\quad$ Disponível em
http://www.alvarodeoliveira.com.br/home/artigos_open.php?funcao=abrir\&id_artigo=8. Acesso em 10/12/2010 355 SOUTO MAIOR, Jorge Luiz. A efetividade do processo. In: CORREIA, Marcus Orione Gonçalves (org.). Curso de direito do trabalho: vol. 4 - Direito processual do trabalho. São Paulo: LTr, 2009, p. 67 
de produção da prova para uma das partes é variável e em sendo assim, será mais adequado que a lei ou o juiz digam quem se encontra em melhores condições de produção, sendo preciso fazê-lo em momento útil, a fim de possibilitar à parte atuação de forma a que consiga produzir a prova que lhe compete e cujo ônus lhe foi, naquele instante, atribuído. ${ }^{356}$

Portanto, o momento da distribuição dinâmica será aquele que propicie o contraditório, pois se uma das idéias do ônus probatório dinâmico, sob a perspectiva subjetiva, é justamente incentivar a produção da prova pelas partes, tem relevo como regra de procedimento e neste caso a decisão do juiz deve ser informada às partes seja na audiência em que se delimitam os fatos controversos seja em momento posterior, mas antes do julgamento final. ${ }^{357}$ Nesse sentido há previsão expressa no anteprojeto do Código de Processo Civil no parágrafo primeiro do artigo 262.

Além da necessidade de decisão fundamentada há que se pontuar que a mesma pode ser proferida de ofício ${ }^{358}$, sem maiores problemas, pois o juiz verificando que naquele caso concreto que a distribuição nos termos do 333 do CPC combinado com o art.818 da CLT não atende os primados constitucionais representando se aplicados ofensa à direitos fundamentais deverá determinar a distribuição dinâmica do encargo probatório.

\footnotetext{
${ }^{356}$ YARSHELL, Flávio Luiz. Antecipação da Prova sem o requisito da urgência e o Direito Autônomo à Prova. São Paulo: Malheiros, 2009, p.95

${ }^{357}$ Igualmente para Guilherme Guimarães Feliciano para quem a distribuição dinâmica do ônus da prova no processo do trabalho representa regra de procedimento de modo que "própria garantia do contraditório e da ampla defesa impõe que a repartição do ônus da prova seja esclarecida às partes, no momento oportuno, caso não se observe o standard legal (arts. 818/CLT e 333/CPC). Já por isso, tais regras de repartição, no processo do trabalho, não são apenas regras de julgamento, mas também regras de procedimento; e como tais devem ser tratadas, na medida em que divirjam do padrão legal-residual e não se assentem em jurisprudência pacífica e sumulada, inclusive para o efeito de prevenir nulidades processuais." In FELICIANO, Guilherme Guimarães. Distribuição dinâmica do ônus da prova no processo do trabalho - Critérios e Casuística. Revista do Tribunal Regional do Trabalho da 15. . Região, n.32, 2008, p.103-112. E ainda para Júlio Cesar Bebber entendendo pela necessidade do prévio contraditório das partes para imputação do ônus nos termos do pensamento dinâmico da prova. In Processo do Trabalho. Adaptação à Contemporaneidade. Tese (Doutorado), Faculdade de Direito, Universidade de São Paulo, 2009, p.158.

${ }^{358}$ Nesse sentido CARPES, Artur Thompsen. Prova e Participação no Processo Civil: Dinamização dos ônus probatórios na perspectiva dos direitos fundamentais. Tese (Mestrado), Faculdade de Direito, Universidade Federal do Rio Grande do Sul, 2008, p.144.
} 
Para Dall Agnol "é, assim, verdadeiro dever do juiz o comportar-se com dinamismo. Não se the pede que realize pela parte a prova, mas seguramente que envide todos os esforços para que o litígio se resolva segundo o alegado e provado, lançando mão dos meios que the oferece o direito positivo para obviar a prova insuficiente, ou mesmo inexistente, antes de abrigar-se sob a regra do art.333 do CPC." 359

Outra questão procedimental diz respeito à possibilidade de recurso quanto à determinação da distribuição dinâmica da prova o que não oferece maiores problemas diante do sistema recursal no processo do trabalho e a previsão da não recorribilidade de decisões interlocutórias, como tal consideradas as manifestações dos juízes acerca da realização de provas. Desta forma, eventual insurgimento em face da distribuição do ônus da prova como realizada pelo juiz do trabalho em primeira instância se dará através do Recurso Ordinário (art.895, "a" da CLT)..

Por fim também em segunda instância por ser tratar de juízo ainda de revisão de matéria fática acredito ser possível a atribuição do ônus da prova dinâmico com determinação de reabertura da instrução processual a fim de que à parte agora onerada possa ser dada a oportunidade de realização da prova.

\subsection{O artigo 818 da CLT - norma processual aberta}

Não há como rechaçar a aplicação do ônus dinâmico da prova sob a justificativa de ausência de previsão legal uma vez que o sistema processual trabalhista representado especialmente pela Consolidação das Leis do Trabalho foi construído de forma aberta, com expressa previsão de integração e complementariedade a outros sistemas desde que congruentes com os princípios de direito e processo do trabalho (art.769 da CLT). Não

\footnotetext{
${ }^{359}$ DALL’AGNOL JUNIOR, Antonio Janyr. Distribuição Dinâmica dos Ônus Probatórios. Revista Jurídica, 137. Porto Alegre, no. 280, 2001, p.20.
} 
bastasse o argumento se afastaria pela possibilidade de interpretação a partir de normas e princípios constitucionais.

Também não podemos perder de vista que o maior escopo do processo trabalhista sempre foi o da maior efetividade da justiça, e para tanto, repita-se, dotado da possibilidade de valer-se de normas processuais civis quando houver expressa lacuna na legislação do trabalho. Essa lembrança abre espaço inclusive para adentrar-se na questão da aplicação da teoria dinâmica da prova no processo do trabalho após a aprovação do projeto do novo código de processo civil de forma subsidiária, rechaçando de fez qualquer obstáculo à sua aplicabilidade.

Ora se a CLT se perfaz num sistema ele próprio dinâmico não há amparo para a não adoção de técnica apta a alcançar uma maior efetividade, celeridade e justiça ao caso concreto até porque esse é o reflexo da nova ordem constitucional.

A adoção dessa técnica representará maior grau inclusive de eficiência dos sistemas processual trabalhista no âmbito da prova e ao final, na concretização dos próprios ideais de Justiça e após a inserção na CLT do artigo 852-D da CLT não é possível outra interpretação que não a abertura a essas novas técnicas.

Há, por fim, uma peculiaridade que resta referir para que se reconheça a total possibilidade de adoção no direito processual do trabalho da teoria das cargas probatórias dinâmicas.

A CLT como visto, mal ou bem, tem uma regra própria relativa ao ônus da prova, ainda que criticada por parte dos operadores do direito, como visto no capítulo II. Entretanto partindo-se de uma perspectiva do art.818 da CLT como uma regra processual 
aberta $^{360}$, já que ela própria não reparte os ônus processuais daquela forma mais circunstanciada prevista no art.333 do CPC podemos concluir que o art.818 da CLT e a atribuição dinâmica do ônus da prova são institutos que não se repelem, mas ao contrário esta última passa a dar conteúdo à disposição celetista.

É a partir da ideia de tutela jurisdicional efetiva que vamos pensar no art.818 da CLT realmente como uma regra processual aberta ao considerar as necessidades do direito substancial do trabalho. Já se falou anteriormente que da interpretação do arcabouço jurídico-processual constitucional confere-se ao juiz um poder-dever de buscar a técnica processual apta à tutela dos direitos de modo a maximizar sua concretização.

Regra aberta é aquele que decorre da aceitação da ideia de que a lei não tem condições de atrelar as técnicas processuais a cada uma das necessidades do direito material ou desenhar tantos procedimentos especiais quanto forem supostos como necessários à tutela jurisdicional dos direitos.

As cláusulas processuais gerais ou também denominadas de normas de conceito aberto apresentam termos ou expressões abertas e, portanto, são dotadas de plasticidade, exigindo um significado a ser preenchido pelo seu intérprete, considerando as circunstâncias do caso concreto. Na verdade, não servem para preencher lacunas esquecidas,

\footnotetext{
${ }^{360} \mathrm{Na}$ doutrina trabalhista há quem considere o art.818 da CLT como regra processual aberta. Entendendo dessa forma também Fabiano Coelho de Souza para quem: "A CLT, de modo simples, mas preciso, regulamenta o ônus da prova em seu art.818, indicando que "a prova incumbe á parte que alegar". Em que pese diversas críticas ao dispositivo, temos que o legislador celetista estabeleceu regra dinâmica para a carga probatória laboral. Nesta perspectiva, a rigor o ônus de prova é do autor para tudo aquilo que alegar, mas será repassado ao réu quando este admite o fato alegado pelo adversário, mas deduz novo argumento. Não se trata de imprecisão normativa como mencionam alguns, mas, sim, de premissa aberta que permite a formação da regra de distribuição do ônus de acordo com o caso concreto, sem predeterminações rígidas. Vale dizer, ainda, que a regra do art.818 da CLT não impede a aplicação de regra mais favorável ao trabalhador, de modo a adequar o encargo probatória às condições reais de isonomia no processo, valendo a incidência de interpretação com base na paridade de armas à disposição dos litigantes". In O princípio da pré-constituição das provas n processo do trabalho. Revista Trabalhista Direito e Processo. São Paulo, no. 31 - outubro, 2009, p.154
} 
mas representam uma forma positivada apta a permitir a aplicação de normas fundamentais no caso concreto para dar vigor ao princípio da efetividade jurisdicional. ${ }^{361}$

Partem as normas processuais abertas de duas constatações: de que as necessidades do direito material se transformam diariamente e que as mesmas assumem contornos variados conforme os casos concretos.

Se de um lado as normas abertas conferem maior poder para a utilização dos instrumentos processuais, por outro exigem do juiz o dever de demonstração da idoneidade de seu uso. Logo, e como não poderia deixar de ser vez que a há exigência constitucional de fundamentação das decisões judiciais, ao interpretar uma norma processual que se repute aberta o magistrado deverá externar a justificativa da sua opção, dada a maior carga de subjetividade que se lhe permitiu. O controle dessas decisões será também de ordem substancial, ou seja, pautado inclusive pela regra da proporcionalidade. ${ }^{362}$

Ainda nessa perspectiva do direito à tutela efetiva percebe-se que passou a ser de extrema relevância o direito de participar adequadamente do processo, não se podendo no Estado Constitucional ignorar a estrutura do procedimento ainda que a partir de uma cláusula processual aberta. ${ }^{363}$ Nota-se, então uma necessidade de vinculação do direito de participação com a situação do direito material, ou seja, "a aferição do direito de participação no caso concreto deve ser feita a partir da tutela jurisdicional de direito almejada" 364

A aplicação das cargas probatórias dinâmicas serve especialmente a proporcionar a tutela jurisdicional efetiva no processo do trabalho, ou seja, é dever do Estado-

\footnotetext{
361 HENRIQUES FILHO, Ruy Alves. Os direitos fundamentais na jurisdição constitucional e as cláusulas gerais processuais. Dissertação (Mestrado.Faculdade de Direito da Universidade Federal do Paraná. Curitiba,2006, p.100 e p.70

${ }^{362}$ MARINONI, Luiz Guilherme; ARENHART, Sérgio Cruz. Curso de Processo Civil. V.2”. São Paulo, Ed. RT, 2007. pp. 119-123.

${ }^{363}$ Idem.Ibidem, p. 224 .

${ }^{364}$ Idem.Ibidem, p.270
} 
Juiz instituir técnicas processuais aptas a satisfazer as tutelas prometidas pelo direito material, quando a lei não mais atende a essa expectativa de concretude. ${ }^{365}$

Assim, diante de uma norma processual aberta, caso do art.818 da CLT, o julgador deverá compensar a inadequação de algum procedimento à luz dos direitos fundamentais, em busca da igualdade substancial, justamente porque essas regras admitem os juízos de ponderação.

Inexistente óbice legal, portanto à aplicação do ônus dinâmico da prova no processo do trabalho vez que a própria disposição do art.818 da CLT já conteria essa autorização implícita decorrente inclusive da sua interpretação consentânea com os princípios de direito material e processual do trabalho. ${ }^{366}$

Nem poderia ser de outra forma, sendo certo que os juízes do trabalho em seus vários níveis de atuação já vêm adotando a teoria dinâmica como se verá a seguir.

\section{Identificação de casos da aplicação da técnica pela magistratura trabalhista}

A teoria dinâmica do ônus da prova não se tratando de regra de atribuição apriorística não torna possível antecipar a sua esfera de aplicação, extraindo-se, por ora, da própria jurisprudência que vem se formando a identificação de alguns pressupostos para aplicação da dinamização do ônus probatório no processo do trabalho.

\footnotetext{
${ }^{365}$ Idem.Ibidem, p. 270

${ }^{366}$ Para Flávio Yarshell somente a lei pode autorizar a dinamização da prova, o que se resolveria, neste caso com a aprovação do Novo CPC. In Antecipação da Prova sem o requisito da urgência e o Direito Autônomo à Prova. São Paulo: Editora: Malheiros, 2009, p.95. Posição contrária apresentam Marino e Arenhart compreendendo que as diversas necessidades do direito material exigem tratamento diferenciado do ônus da prova mesmo na ausência lei, e indicam que há países que sequer tem norma similar a do art.333 prevista em lei, caso do ordenamento alemão. MARINONI, Luiz Guilherme; ARENHART, Sérgio Cruz. Prova. São Paulo: Revisa dos Tribunais, 2010, pp.186-187
} 
Mesmo ausente regra expressa na legislação infraconstitucional, muitos de nossos tribunais especializados tem se mostrado apartados de uma concepção meramente legalista e vêm reconhecendo aplicabilidade prática à teoria da carga dinâmica probatória, a partir de uma interpretação sistemática e coerente com o texto constitucional, o que é um avanço.

\subsection{As recentes manifestações da jurisprudência trabalhista}

Através de pesquisas realizadas em repertórios jurisprudenciais especialmente através dos sítios dos Tribunais Regionais do Trabalho de todo o Brasil e também do Tribunal Superior do Trabalho encontraram-se apenas alguns exemplos da adoção pelos juízes e desembargadores da técnica da distribuição dinâmica do ônus da prova. Importante registrar que a pesquisa realizada não é definitiva seja em razão do espectro temporal bem assim da limitação técnica da publicação das decisões trabalhistas em especial de primeira instância o que inviabilizou a investigação de toda a gama de sentenças emanadas nos últimos tempos na esfera trabalhista nacional.

Ultrapassadas as limitações materiais acima referidas passa-se a apontar o resultado, ainda que tímido da busca realizada em torno da questão da adoção pelos juízes e desembargadores do trabalho da teoria da distribuição dinâmica do ônus da prova. Omite-se a referência a decisões de Ministros do Tribunal Superior do Trabalho pois na mais alta corte trabalhista esta pesquisadora não encontrou, ainda, decisão atribuindo o ônus da prova a partir da teoria da distribuição dinâmica, o que se justifica pela própria esfera de competência daquela instância onde, a princípio, não há mais revisão das questões de prova e via de consequiência, análise de atribuição, inversão ou distribuição do ônus da prova. Talvez e a partir do crescimento da adoção pelas instâncias inferiores da carga probatória dinâmica iniciem-se as manifestações do Tribunal Superior do Trabalho após questionamentos acerca de ferimento de lei federal, objeções constitucionais e outras aptas a sustentar e fundamentar os recursos de revista. 
No âmbito do Tribunal Regional da $2^{\mathrm{a}}$ Região o juiz Rodrigo Garcia Schwarz no ano de 2008 já aplicara a teoria da distribuição dinâmica do ônus da prova em caso de reclamação trabalhista na qual se discutiu o direito do trabalhador à integração das comissões pagas e não consignadas no recibo salarial, ou seja, as chamadas comissões "por fora":

\section{“(...) 2.2. QUESTÃO PREJUDICIAL - COMISSÕES}

O reclamante alega o pagamento de comissões "por fora", em valores superiores àqueles consignados nos recibos de pagamento de salários. Os documentos às fls. 15-6, por amostragem, reportam-se ao faturamento mensal do estabelecimento e ao percentual das comissões incidentes, e não foram impugnados, neste aspecto, pela reclamada. A alegação da reclamada, no sentido de que o faturamento mensal e o percentual de comissões incidentes, apontados nos documentos, não se referem apenas às vendas realizadas pelo reclamante, mas à totalidade das vendas realizadas, carece de prova. Pagando comissões sobre vendas, competia à reclamada provar o quantum das vendas e das correspondentes comissões pagas ao reclamante, no que negligenciou. É a reclamada, que tem a obrigação legal de manter livros fiscais (e, mesmo tratando-se de micro-empresa, ao menos o livrocaixa), que está em posição de provar, documentalmente, qual é o exato valor das vendas realizadas pelo reclamante, mês a mês, e qual é o exato valor das comissões pagas, demonstrando os valores escriturados. Não o fez, de forma que se presume a correção dos fatos expostos pelo reclamante na petição inicial, no tópico. A carga probatória é dinâmica, incidindo, aqui, o princípio da aptidão para a prova, de forma que compete à parte que naturalmente melhor detém os meios de prova o ônus de provar as suas alegações, observados os termos do artigo 818 da Consolidação das Leis do Trabalho. Nesse contexto, à falta de provas em contrário, e tendo em conta a prova documental produzida pelo reclamante, estimo, por razoável, em $\mathrm{R} \$ 2.500,00$ o seu salário médio total, mensal. O valor dos salários mensais deverá ser observado para o cálculo das demais parcelas postuladas pelo obreiro na presente reclamação, se deferidas nesta decisão. ${ }^{367}$ (g.n.)

Observa-se no caso ilustrado que o aplicador do direito adotou inicialmente como critério a obrigatoriedade da manutenção de documentos fiscais pela empresa (no que poderíamos antever a própria obrigatoriedade de pré-constituição de prova pelo empregador) e

367 Sentença da lavra do juiz Rodrigo Garcia Schwarz em 29/09/2008 nos autos do processo no. 00215-2008315-02-00-9 originário da $5^{\text {a }}$ Vara do Trabalho de Guarulhos. Consulta ao site do Tribunal Regional do Trabalho de São Paulo em 10/01/2010. 
do princípio da aptidão para a prova. Fez ainda expressa referência à carga probatória dinâmica ao atribuir à parte ré o ônus de provar qual era o real valor das comissões percebidas pelo empregado sobre as vendas realizadas, nada obstante os valores já consignados nos recibos de pagamento os quais eram impugnados por não retratar a totalidade do montante efetivamente pago ao trabalhador.

Igualmente discutindo o ônus da prova do pagamento das comissões em recibo apartado a $18^{\mathrm{a}}$ Turma do Tribunal Regional do Trabalho de São Paulo através do Acórdão exarado no processo $\mathrm{n}^{\mathrm{o}}$ 00353-2007-009-02-00-0-18 tendo como relatora a juíza Celita Carmen Corso assim decidiu:

\begin{abstract}
“(...) Por fim, tangenciando a questão da integração das "comissões" referente a todo o período do contrato de trabalho, cumpre referir que, à luz da teoria da distribuição dinâmica das cargas probatórias, positivada no art. $6^{\circ}$, VIII, do CDC, o ônus da prova incumbe a quem, pelas circunstâncias do caso concreto, se encontre em melhores condições para produzir a prova, visando a garantir maior efetividade à tutela jurisdicional.

Neste sentido, confira-se precedente do STJ: “A teoria da dinâmica da prova transfere o ônus para a parte que melhores condições tenha de demonstrar os fatos e esclarecer o juízo sobre as circunstâncias da causa”. (STJ - REsp 316316 - excerto do voto do Rel.Min. Ruy Rosado de Aguiar - DJ 12.11.2001).

$\mathrm{Na}$ espécie - considerando que o relatório de produtividade dos empregados é documento afeto à reclamada - entendo que esta possui melhores condições de comprovar que não pagava qualquer percentual (comissões) sobre o seu faturamento, decorrente dos contratos de arrendamento celebrados pelo reclamante, bastando, para tanto, colacionar os relatórios atinentes a todo o período do contrato de trabalho. Se assim não o fez, omitindo-se deliberadamente, deve sofrer as consequiências do descumprimento deste ônus processual, vale dizer, a procedência do pleito autoral." 368
\end{abstract}

Vislumbra-se do aresto supra que houve a identificação da teoria da distribuição dinâmica do ônus da prova com a regra disciplinada no Código de Defesa do Consumidor. Optou a relatora por atribuir o ônus da prova a quem detivesse melhores

368 Acórdão do Processo no. 00353-2007-009-02-00-0-18a Turma - RECURSO ORDINÁRIO Disponibilização e verificação de autenticidade no site www.trtsp.jus.br informando. Código do documento $=32300$. Consulta ao site do Tribunal Regional do Trabalho de São Paulo em 10/01/2010. 
condições de produzi-la com vistas, inclusive à própria efetividade da tutela jurisdicional. E em idêntica posição à do juiz Rodrigo Schwarz imputou à parte reclamada, no caso à empresa, a responsabilidade pela manutenção de documentos (relatório de produtividade de empregados) como meio apto à comprovação da tese de inexistência de pagamentos extrafolha e considerando a omissão como deliberada de modo a dar razão à parte reclamante em seu pleito.

As manifestações do Tribunal Regional de São Paulo não se limitam ao encargo da prova das comissões "por fora". Acórdão da 1a. Turma recentemente exarado nos autos do processo TRT/SP No 00397200703802006 em que o relator juiz Marcos Neves Fava ao julgar recurso ordinário reformou a sentença de primeiro grau em questões fundamentais a partir da adoção da técnica da distribuição dinâmica do ônus da prova.

O questionamento inicial provém da especulação sobre a prova da existência dos pressupostos para a configuração do exercício das mesmas funções e tarefas entre os empregados, o que tem por pano de fundo, por óbvio o direito constitucional à igualdade salarial. Percebe-se a partir da análise da decisão que o magistrado aplicando a distribuição dinâmica do ônus da prova tornou incumbência da ré a demonstração de que o empregado postulante era substituído por outrem. Segue trecho do Acórdão:

"Ao ser ouvido em juízo, o reclamante confirmou exercer todas as atividades, exceto a de advertir, que deveria ser submetida a autoridade superior (diretor).

A sentença a quo viu nisto o reconhecimento de que não houve substituição integral, indeferindo o pedido de diferenças salariais.

Tem razão o recorrente. Em linha nenhuma da defesa consta a indicação de que, sem submeter a outrem, o substituído Josué poderia advertir formalmente seus subordinados. A peça de resistência diz apenas que ele coordenava o setor, distribuindo tarefas e supervisionando sua realização.

A confirmar o fato, ouviu-se apenas uma testemunha, a segunda do reclamante, que foi peremptória em afirmar que "diversas vezes o reclamante substitui o $\mathrm{Sr}$. Josué" (f. 66).

Não há como negar a confirmação do fato constitutivo do direito do recorrente, registrando-se que ao empregador, pela distribuição dinâmica do ônus da prova, incumbia a demonstração do impeditivo, a saber, a indicação e a prova de que Josué era substituído por outrem. Esta prova não se realizou, porque testemunhas não ouviu a recorrida. 
Resta, pois, apenas a confirmação do fato alegado na inicial, do qual emana o direito à percepção das diferenças. (g.n.). ${ }^{369}$

O magistrado paulista não está sozinho na atribuição dinâmica do ônus da prova à reclamada quando se discutem os fatos da isonomia salarial. O Tribunal Regional do Trabalho de Minas Gerais nos autos do Processo no. 0144500-02.2009.5.03.0111 RO, de 22/11/2010 (DEJT - Página: 296) cujo relator foi o juiz convocado Vitor Salino de Moura Eça entendeu que nos casos de equiparação salarial o empregador detendo acentuadamente os meios probatórios, atrai para si o ônus da prova em razão da teoria da distribuição do ônus da prova, que, como uma técnica processual deve a princípio estar estabelecida na lei, o que não impede sua atribuição supletiva pelo magistrado trabalhista. Prima, portanto, o Acórdão em tela por reconhecer ao juiz do trabalho esses poderes de determinação do ônus da prova conforme o caso concreto, bem assim por apontar o dever de colaboração ativa das partes. Segue transcrição da ementa e do trecho completo como nota de rodapé a fim de evitar-se repetição inútil e cansativa:

"EMENTA: DISTRIBUIÇÃO DINÂMICA DO ÔNUS DA PROVA. FIXAÇÃO
PELA JURISPRUDÊNCIA. POSSIBILIDADE. A distribuição do ônus da prova
consiste em uma técnica processual, cuja disposição cabe, em princípio, à lei.
Todavia, esta não é a única fonte de direito. A jurisprudência também ostenta esse
poder. Destarte, dentro do acervo de possibilidades da Corte trabalhista a chance
de, supletivamente, atribuir o ônus da prova a uma das partes. Assim é quando a
pretensão importa em uma equiparação salarial, terreno em que os elementos
probatórios se concentram acentuadamente junto aos documentos de porte
obrigatório do empregador, daí porque, segundo a moderna teoria da
distribuição dinâmica do ônus da prova, fica este último com o dever
processual de colaborar com a Justiça ativamente. (g.n.). ${ }^{370}$

\footnotetext{
${ }^{369}$ Disponibilização e verificação de autenticidade no site www.trtsp.jus.br informando: codigo do documento = 36496. Tribunal Regional do Trabalho $-2^{a}$ Região. PROCESSO TRT/SP N. ${ }^{\circ} 00397200703802006$. Acesso ao site em $12 / 12 / 2010$.

${ }^{370}$ Trecho integral do Acórdão de onde foi extraída a ementa: “(...) EQUIPARAÇÃO SALARIAL. A reclamada alega ser incabível a equiparação deferida, uma vez que nunca houve identidade de funções entre os paradigmas e o autor, sendo que este não se desincumbiu de seu ônus probatório. Diz que a prova testemunhal produzida deixou claro que os paradigmas tinham produtividade superior à do reclamante. Sem razão. Na peça de ingresso, o obreiro aduziu que, por todo o período trabalhado exerceu funções idênticas àquelas exercidas pelo Sr. Celso Augusto e pela Sra. Rita de Cássia. Entretanto, mesmo sendo o trabalho exercido com a mesma produtividade e perfeição técnica que os paradigmas, o autor percebeu durante todo o pacto laboral, remuneração inferior àqueles.

As fichas financeiras colacionadas pela reclamada às fls. 172/266 corroboram a diferença salarial existente entre o salário do reclamante e dos paradigmas apontados.
} 
Continuando ainda a análise da decisão da $1^{\mathrm{a}}$. Turma do TRT de São Paulo passa-se ao tópico pertinente à prova dos fatos causadores do dano moral postulado pelo reclamante. Segundo o autor a dispensa sem justa causa ocorrera após pedir à empregadora indenização pelo furto de veículo próprio no estacionamento da empresa o que lhe acarretara dano moral e uma vez mais à luz do ônus da prova dinâmico o magistrado atribuiu o encargo da prova dos motivos ensejadores do rompimento do pacto laboral à empregadora e nos seguintes termos:

“(...) A defesa sustenta que se trata de mera redução de quadros. A distribuição dinâmica do ônus da prova entregava, a essa altura, à recorrida, o ônus de delinear quais e quantos foram demitidos na ocasião do 'corte', em quais setores, ou, ao menos, trazer quantitativamente a variação de empregados e desempregados, para confirmar não se tratar de ato discriminatório. Não o fez, no entanto, permitindo

O conjunto da prova documental relativa à matéria, contudo, não é determinante, já que a mera denominação de cargos, em se tratando de equiparação salarial, firma presunção apenas relativa de veracidade no que toca ao trabalho efetivamente prestado, segundo inteligência do item III da Súmula 06 do TST.

A equiparação salarial só é possível se o empregado e os paradigmas exercerem a mesma função, desempenhando as mesmas tarefas, não importando se os cargos têm, ou não, a mesma denominação.

No que tange ao restante da prova produzida, a testemunha indicada pelo reclamante confirmou, à fl. 340, a identidade de funções, nos seguintes termos: "...que Celso era técnico de enfermagem e Rita de Cássia, salvo engano, técnica de enfermagem também; que ambos exerciam as mesmas funções do reclamante; que não havia diferença da função de técnico e auxiliar de enfermagem, apenas o salário...”

Nesse mesmo sentido, relatou a sra. Vera Galdino costa, testemunha ouvida a rogo do reclamante (fls. 340/341): “...que conheceu os paradigmas trabalhando juntos, exercendo as mesmas funções do reclamante, inclusive porque havia rodízio; que todos passavam pelas mesmas fases da esterilização; que não havia diferença na execução dos serviços entre técnico e auxiliar de enfermagem..."

Verifica-se, portanto, que a prova oral colhida nos autos mostrou-se favorável à pretensão obreira, evidenciando que, de fato, existia identidade funcional entre os paradigmas.

Ademais o ônus probatório é do empregador. Com efeito, a distribuição do ônus da prova consiste em uma técnica processual, cuja disposição cabe, em princípio, à lei. Todavia, esta não é a única fonte de direito. A jurisprudência também ostenta esse poder. Destarte, dentro do acervo de possibilidades da Corte trabalhista a chance de, supletivamente, atribuir o ônus da prova a uma das partes. Assim é quando a pretensão importa em uma equiparação salarial, terreno em que os elementos probatórios se concentram acentuadamente junto aos documentos de porte obrigatório do empregador, daí porque, segundo a moderna teoria da distribuição dinâmica do ônus da prova, fica este último com o dever processual de colaborar com a Justiça ativamente. (g.n.)

Nesse sentido, não foi demonstrada qualquer diferença de qualidade técnica ou produtividade entre os mesmos, Logo, o obreiro comprovou a identidade funcional necessária à equiparação pretendida, e a reclamada não logrou demonstrar os fatos impeditivos, modificativos ou extintivos do direito em tela, como lhe competia, conforme inteligência do item VIII da Súmula 06 do c. TST, in verbis: "VIII - É do empregador o ônus da prova do fato impeditivo, modificativo ou extintivo da equiparação salarial."

Em face de todo o exposto, nega-se provimento ao recurso.”. Disponível em HTTP://gsa;trt3.jus.br/search?q=\&sort=date\%3AD\%3AL\%3Ad1\&entqr+3\&output=xml_no..., $\quad$ consulta em 14/12/2010. 
assentar-se conclusão no sentido de que houve má-fé na quebra do contrato de trabalho do recorrente. ${ }^{371}$

371 Disponibilização e verificação de autenticidade no site www.trtsp.jus.br informando: codigo do documento = 36496. Tribunal Regional do Trabalho $-2^{\mathrm{a}}$ Região. PROCESSO TRT/SP N.. 00397200703802006. Acesso ao site em 12/12/2010. Segue trecho do Acórdão no tocante à decisão sobre o dano moral a fim de perceber, na sua extensão, a atribuição do ônus da prova à reclamada a partir da adoção da teoria dinâmica: (...) 4.Dano moral. A alegação central coincide com a denúncia de que, após o furto do carro do reclamante do estacionamento da reclamada, como a empresa não indenizava o recorrente, suas reclamações ao encarregado acabaram por custar seu contrato de emprego, em razão do que enfrentou dano moral.

Os fatos acerca do infortúnio restaram confirmados, porque o autor junta os Boletins de Ocorrência do furto (f. 25) e da devolução do carro incinerado (f. 27), enquanto a reclamada omite-se em provar que houve ressarcimento do prejuízo, em razão de ter sido o carro furtado de seu estacionamento. É inquestionável que tal dever não emane do contrato de trabalho, mas das obrigações consumeiristas, eis que o autor estava com seu veículo ali estacionado na condição de consumidor.

Postos os fatos assim, e considerando-se o tempo havido entre o furto (22 de agosto) e a demissão ( 8 de novembro), passa-se à análise do alegado.

A discrepância entre os contratantes é o marco da relação de trabalho, responsável pela criação do ramo especializado do direito, desde fins da primeira revolução industrial, que tem o fito único de equiparar os atores, dando proteção ao hipossuficiente, em face do empregador.

Muitos modos há de abuso do poder econômico característico dessa relação, como se colhe quotidianamente nos corredores do fórum. Quebra da isonomia, ausência de registro, falta de pagamento das rescisórias, insuficiência de pagamento do fundo de garantia por tempo de serviço, omissão na expedição de comunicado de acidente etc. No plano dos direitos da personalidade, os abusos aparecem mais marcados, não surgem, note-se bem, mas aparecem mais marcados no direito brasileiro nos últimos quinze anos, quando se passou a considerar a possibilidade de indenização por danos morais no seio do contrato de trabalho.

A demissão sem justa causa é, em si, ofensa ao princípio da boa-fé objetiva, como consagrado pelo direito pátrio, por exemplo, no artigo 422 do código civil de 2002. A avença laboral faz-se para ser contínua, porque dela advém o sustento do trabalhador e de sua família, significando, o abrupto romper, situação de angústia e desamparo. Em ordenamentos mais avançados, como prepondera, vg, na Europa, toda demissão há de ser motivada. Entre nós isto constitui mera promessa constitucional contida no artigo $7^{\circ}$, I da Carta, ainda não regulamentado, mais de vinte anos após a promulgação da Constituição.

Como não há necessidade de motivação das rescisões, repete-se, como faz a defesa da recorrida, à farta, que o direito de demitir é potestativo do empregador, bastando-lhe a indenização. Se é possível admitir a verdade desta premissa, no mais das vezes, situações há em que não se pode aceitá-la. O caso concreto exibe uma delas.

O autor, empregado, não teria meios de coação a exigir da recorrida, empregadora, a indenização pelo furto de seu veículo. Em que pese a distinção entre as figuras, de um lado, do consumidor e do empregado, e de outro, do fornecedor e do empregador, indiscutível é que recaem sobre as mesmas pessoas (física e jurídica). O trabalhador é, a um tempo, no caso concreto, empregado e consumidor. Sem proteção do emprego, não pode ir a juízo, exigir a reparação do dano. A única via capaz de intentar o remédio, no curso do contrato, seria reclamar, quanto possível, aos imediatos.

Vejo, desta perspectiva, confirmada a hipótese levantada nos autos, de que a demissão veio para calar o recorrente de suas pretensões indenizatórias do infortúnio havido no estacionamento da recorrida.

A defesa sustenta que se trata de mera redução de quadros. A distribuição dinâmica do ônus da prova entregava, a essa altura, à recorrida, o ônus de delinear quais e quantos foram demitidos na ocasião do 'corte', em quais setores, ou, ao menos, trazer quantitativamente a variação de empregados e desempregados, para confirmar não se tratar de ato discriminatório. Não o fez, no entanto, permitindo assentar-se conclusão no sentido de que houve má-fé na quebra do contrato de trabalho do recorrente.

No que tange à prova do dano moral, importa ver que a ofensa pessoal perpetra-se contra o caráter mais íntimo do cidadão, calando-lhe fundo e de forma grave, não sendo relevantes, para a constatação de que dano existiu, os reflexos externos dessa mácula. Alguém que, em particular, ofenda a outrem, pratica ato ilícito de que emana dano pessoal, em que pese o xingamento ter ocorrido em particular. A doutrinal identifica o 
Observando-se o teor da decisão pode ser constatado que o julgador partiu de determinadas premissas para a aplicação do ônus dinâmico da prova. Pautou-se inicialmente pela constatação da hipossuficiência do trabalhador e da ausência de isonomia entre as partes e por fim na aplicação do princípio da boa-fé dos contratos. Deste modo ao associar esses fatores passou a atribuir à ré o ônus de provar que a dispensa não se dera em razão das reclamações do autor acerca de indenização devida a ele por furto de veículo no estabelecimento da empresa. Essa decisão atende especialmente a um dos critérios essenciais para atribuição do ônus dinâmico da prova, qual seja o critério pertinente à superação da desigualdade material dos litigantes.

Um dos Tribunais Regionais do Trabalho onde têm aflorado expressivas decisões sobre as cargas probatórias dinâmicas é o do Rio Grande do Sul. Partindo de critérios como o da verossimilhança das alegações a juíza Maria Helena Mallmann atribuiu à empresa o ônus da prova da ausência dos requisitos celetistas da relação de emprego. Segue decisão em parte transcrita:

prejuízo como dano pessoal direto. Claro está que o ataque público pode ampliar o prejuízo, mas sua existência não se vincula às consequências externas.

Nesta hipótese, o cidadão exerce seu direito legítimo de reclamar o pagamento da indenização a que faz jus e o empreendedor, estribado em seu duplo poder hiper-suficiente, de empregador e de fornecedor, não só nega a indenização, como pune o reclamante, termo a esta altura utilizado como sinônimo de reclamador, com demissão sem justa causa.

Perpetra-se, pois, ato ilícito, porque a demissão imotivada é lícita, mas a que pretende calar o trabalhador viola o dever geral de boa-fé objetiva, da qual emana dano pessoal (moral), configurando-se os elementos da responsabilidade civil subjetiva, aptos a autorizar o deferimento da indenização. $\mathrm{O}$ autor perdeu um gol 1994 (BO, f. 27), cujo valor, segundo consulta ao sítio da FIPE, gira em torno de R\$11.000,00. O último salário do reclamante era de $R \$ 756,18$. A inicial postula $R \$ 15.123,60$, mas não apresenta fundamento objetivo para seu intento. Levando em conta a correlação de valores, o porte econômico da reclamada e o caráter dúplice da indenização - aplacar o sofrimento do ofendido e desincentivar o ofensor de reincidir - defiro compensação de $\mathrm{R} \$ 11.000,00$, em valores desta data, desde quando serão atualizados monetariamente, incidindo, no entanto, ex lege, juros desde a distribuição do feito.

ACORDAM os Magistrados da 1. ${ }^{a}$ Turma do Tribunal Regional do Trabalho da 2. ${ }^{a}$ Região em: DAR PROVIMENTO PARCIAL ao recurso ordinário do reclamante, para julgar procedentes em parte seus pedidos iniciais, declarando existente o vínculo de emprego anterior ao registro e condenando a recorrida (reclamada), do período imprescrito, a: (1) anotar o contrato correto em carteira de trabalho e previdência social do reclamante, no prazo assinalado e sob pena de multa, (2) depositar o fundo de garantia por tempo de serviço do período sem registro, com indenização de $40 \%$, liberando, também sob pena de multa, no prazo marcado, os documentos para saque e (3) pagar ao reclamante: (a) férias com o terço constitucional de 2001-02, (b) diferenças salariais por substituição e reflexos, (c) indenização por danos morais. Custas pela recorrida, fixadas em R $\$$ 400,00 , sobre o valor arbitrado à condenação de $\mathrm{R} \$ 20.000,00$, para recolhimento em 8 dias, pena de execução." 
“EMENTA: DISTRIBUIÇÃO DO ÔNUS DA PROVA. VÍNCULO DE EMPREGO. A ausência de verossimilhanca na tese defensiva impede que se transfira à reclamante o ônus da prova, nos termos da teoria da distribuição dinâmica do ônus da prova. (g.n.)

(...)

\section{VÍNCULO DE EMPREGO. DISTRIBUIÇÃO DO ÔNUS DA PROVA. RECONHECIMENTO.}

Insurge-se a reclamante contra o não reconhecimento da relação de emprego. Nega exercesse a função de "garota de programa". Diz que o estabelecimento possuía vários andares, e que "a reclamante era responsável pela venda de bebidas $e$ manutenção de espaço em apenas um dos andares". Observa que apesar do tamanho do estabelecimento o reclamado aduz que não possui empregados e é o único responsável pela venda de bebida, limpeza e administração do lugar. Diz que as notas fiscais emitidas em nome da reclamante tiveram o objetivo de mascarar relação de emprego. Alega que as notas fiscais são incompatíveis com a caracterização da reclamante como mera freqüentadora. Aduz ainda que, enquanto a contestação afirma que a reclamante se utilizou do estabelecimento a partir de abril de 2007, a primeira nota foi emitida em novembro de 2006. Defende que o ônus da prova era do reclamado. Invoca a prova testemunhal, que entende lhe ter sido favorável.

À análise.

A r. sentença assim decidiu a questão:

"A relação jurídica havida entre as partes não era de emprego. Note-se que o réu não assume a prestação de trabalho, mantendo o ônus da prova com a parte autora, do qual ela não se desincumbe a contento, consoante artigo 818 da CLT.

Note-se que a autora não faz a autora prova de que laborou para o reclamado. Antes pelo contrário, a prova oral dá conta de que a reclamante freqüentava o local como cliente, informação vinda da testemunha Ariane (fls. 131/2), pessoa que era, nas mesmas condições que a reclamante, cliente da empresa, prestando, portanto, depoimento mais coerente que as demais testemunhas, por ter vivenciado de forma mais próxima os fatos objeto deste feito.

De outro lado, as testemunhas convidadas pela autora prestam depoimento contraditório com o que consta da inicial. A segunda testemunha aduz que freqüentava, as vezes, o local pela manha, informação esta que não se confirma quando comparada com a inicial, que aduz trabalho a partir das $12 \mathrm{~h}$.

Assim, pela falta de provas da dependência e permanência, requisitos do artigo $3 o$ da CLT, improcede o pedido de reconhecimento do vínculo de emprego."

Com a devida vênia, não é esta a análise mais correta da questão.

Inicie-se pelo ônus da prova.

Não se desconhece a orientação tradicional de que a chamada negativa absoluta implica em se considerar da parte autora o ônus da prova da relação empregatícia. Todavia, veja-se que a contestação alega que (fl. 71): “O reclamado tem um estabelecimento no endereço onde está direcionada a demanda, um ponto de vendas de bebidas. Nesta situação, a reclamante e outras mulheres, compareciam para tratarem de assuntos exclusivamente particulares com os clientes do rdo, invariavelmente assuntos amorosos, utilizando a reclamante o pseudônimo de "LISI". Portanto, a tese defensiva é de que o reclamado tinha um bar freqüentado 
por profissionais do sexo (note-se que já aqui se admite que havia mais de uma), que, conforme a própria defesa admite, realizavam negócios com os clientes do reclamado, mas que porém ele tirava proveito apenas da venda de bebidas. Portanto, o que defende é que existiam duas prestações de serviço simultâneas e afins (venda de bebidas alcoólicas e serviços típicos de profissionais do sexo), porém sem relação nenhuma entre si. Contudo, é muito pouco razoável que o estabelecimento tivesse só o objetivo de venda de bebidas, e apenas por acaso fosse freqüentado por várias profissionais do sexo -entre as quais, segundo o que a defesa alega, a reclamante-, que ali realizavam sua atividade. A improbabilidade da tese defensiva impede que se atribua o ônus da prova à reclamante, ante a teoria da distribuição dinâmica do ônus da prova Esta Relatora já possui precedentes nesta linha, dos quais destaca-se o seguinte: "DISTRIBUIÇÃO DINÂMICA. ÔNUS DA PROVA. As regras de distribuição do ônus da prova previstas nos arts. 333 do CPC e 818 da CLT estão ambas ultrapassadas, pois que sua rigidez não dá conta de abarcar adequadamente a riqueza das situações que se colocam no cotidiano forense. Por isso, a doutrina, há tempos, desenvolve teorias alternativas de repartição do ônus da prova, dentre as quais se destaca a distribuição dinâmica. Tal teoria apregoa a necessidade de distribuição do ônus probatório conforme situação do caso concreto. Há que se levar em conta a verossimilhança das alegações, bem como a facilidade na produção da prova, não sendo suficientes para a imposição de ônus probatórios impugnações que não tenham amparo na razoabilidade e na ordinariedade dos fatos usualmente verificados. Provimento negado.” (005402005-004-04-00-0 RO, $3^{a}$ Turma, DJ 19.01.09)

Para afastar qualquer dúvida, observe-se que o reclamado, quando da perícia técnica, "Afirmou ser proprietário de uma casa de encontros sexuais" (fl. 105). Tal afirmativa não foi negada na manifestação sobre a perícia (fl. 114). Portanto cabia ao reclamado o ônus da prova." $372^{3}$

No Estado da Bahia foi possível obter decisões de primeiro grau ${ }^{373} \mathrm{de}$ autoria do juiz Marcelo Prata aplicando a regra dinâmica do ônus da prova nas questões relativas ao vale transporte, uma das quais segue transcrita em parte:

\section{"INDENIZAČÃO DO VALE-TRANSPORTE - PRINCÍPIO DA PREVALÊNCIA DA LEI - TEORIA DA CARGA DINÂMICA DA PROVA (...)}

O Decreto n. ${ }^{\circ} 95.247$, de 17 de novembro de 1987 - que regulamenta a Lei n. $^{\circ}$ 7.418/85, que instituiu o vale-transporte, com a alteração da Lei n. ${ }^{\circ} 7.619 / 87$ dispõe:

\footnotetext{
372 Trecho do Acórdão do Processo no. 0087200-44.2008.5.04.0029 (RO), de relatoria da Desembargadora Maria Helena Mallmann em data de 29/07/2009. Disponibilização e verificação de autenticidade no site www.trt4.jus.br. Consulta ao site do Tribunal Regional do Trabalho do Rio Grande do Sul em 14/12/2010.

${ }^{373}$ Sentenças $1^{\circ}$. Grau TRT/BAHIA: Processo 0000773-24.2010.5.05.0004 RT Ord, Juiz Marcelo Prata, Data 29/09/2010 e Processo 0000858-10.2010.5.05.0004 RT Ord, Juiz Marcelo Prata, Data 26/10/2010. Disponível em www.trt5.jus.br. Última consulta em 14/12/2010.
} 
Art. $7^{\circ}$ - Para o exercício do direito de receber o Vale-Transporte o empregado informará ao empregador, por escrito:

I - seu endereço residencial;

II - os serviços e meios de transporte mais adequados ao seu deslocamento residência-trabalho e vice-versa.

$\S 1^{\circ}$ - A informação de que trata este artigo será atualizada anualmente ou sempre que ocorrer alteração das circunstâncias mencionadas nos itens I e II, sob pena de suspensão do benefício até o cumprimento dessa exigência. (Sublinhamos.)

Baseada no dispositivo citado, a Orientação Jurisprudencial $n^{\circ} 215$ do TST diz que "é do empregado o ônus de comprovar que satisfaz os requisitos indispensáveis à obtenção do vale-transporte".

(...)

Assim, sustentamos que a interpretação dada ao art. $7^{\circ}$ do Decreto ${ }^{\circ}$ 95.247/87, no sentido de que ele impõe ao operário apresentar ao empregador seu endereço residencial, bem como os meios de transporte mais adequados ao seu deslocamento para o trabalho, por escrito, termina por limitar extremamente o alcance da Lei $\mathrm{n}^{\circ} 7.418 / 85$. Isso porque a imensa maioria dos trabalhadores não tem condições socioeconômicas, intelectuais ou hierárquicas de produzir tal documento, muito menos de exigir da empresa o respectivo comprovante de entrega.

Por seu turno, escrevendo sobre a Teoria da Carga Dinâmica da Prova, disse ANTÔNIO JANYR DALL'AGNOL JUNIOR:

A denominada teoria das cargas processuais dinâmicas, se não concebida por JORGE W. PEYRANO, ilustre jurista argentino, foi, sem dúvida, por ele desenvolvida em obras que mereceram ampla divulgação no meio hispanoamericano [...]: "En tren de identificar la categoria de las 'cargas probatórias dinâmicas', hemos visualizado - entre otras - como formando parte de la misma a aquélla según la cual se incumbe la carga probatória a quien - por las circunstancias del caso y sin que interese que se desempene como actora o demandada - se encuentre em mejores condiciones para producir la probanza respectiva". A tese, aparentemente singela, rompe com a concepção "demasiado rígida y apríorística" da doutrina clássica, que adotava uma "visión exclusivamente estática" a questão relativa às regras da distribuição dos ônus da prova. [...] Há de demonstrar o fato, pouco releva se alegado pela parte contrária, aquele que se encontra em melhores condições de fazê-lo [...].

A propósito, a aludida Teoria da Carga Dinâmica da Prova, aos poucos, vem recebendo acolhida dos Tribunais Superiores de nosso país. Por sinal, leia-se este recente escólio do C. STJ:

[...] à luz da teoria da carga dinâmica da prova, não se concebe distribuir o ônus probatório de modo a retirar tal incumbência de quem poderia fazê-lo mais facilmente e atribuí-la a quem, por impossibilidade lógica e natural, não o conseguiria. [...] (REsp 619.148/MG, Rel. Ministro LUIS FELIPE SALOMÃO, QUARTA TURMA, julgado em 20/05/2010, DJe 01/06/2010) 
Por sua vez, o vale-transporte é parcela importante para a renda familiar do obreiro, assim, ele é devido, ainda que o reclamante não consiga demonstrar que atendeu as exigência do art. $7^{\circ}$ do Decreto $n^{0}$ 95.247/87, em homenagem, igualmente, ao princípios protetivo e da razoabilidade. Afinal, “...não é lógico nem razoável que o empregado não queira usufruir do benefício que lhe foi outorgado".

Ademais, não se olvide que a parte reclamada, durante a relação de emprego, tem ampla oportunidade e meios para obter, da própria parte reclamante, a prova pré-constituída referida. (g.n.)

Desse modo, em face do princípio da responsabilidade civil na reparação do dano, impossibilitando o empregador que o laborista receba o vale-transporte, deverá arcar com o ônus respectivo, por força do art. 927 do $\mathrm{CCb} \mathrm{c} / \mathrm{c}$ o art. $8^{\circ}$ da CLT. Veja-se, porém, o dito pela a Lei no 7.418, de 16 de dezembro de 1985: "Art. $4^{\circ}$ - [...] Parágrafo único. O empregador participará dos gastos de deslocamento do trabalhador com a ajuda de custo equivalente à parcela que exceder a $6 \%$ (seis por cento) de seu salário básico". Logo, apenas o valor equivalente às despesas de transporte superiores a 6\% do salário básico da parte reclamante deverá ser arcado pela empregadora. Defiro em parte.” (Processo 0000858-10.2010.5.05.0004)

Balizou-se o magistrado na sua tese argumentativa nos princípios protetivo e da razoabilidade e na obrigatoriedade de prova pré constituída pela ré, o que portanto podem ser considerados como diretrizes de atribuição da prova à empresa nos casos que envolvam os benefícios do vale-transporte.

Nas hipóteses de ônus da prova das horas extras tem sido mais frequente a adoção pelo julgador da distribuição dinâmica, impondo-se a transcrição de parte de alguns julgados:

- Acórdão do Tribunal Regional do Trabalho do Rio Grande do Sul:

"Com efeito, nos termos do art. 333 do CPC c/c art. 818 da CLT, a regra geral é que ao autor incumbe o ônus da prova do fato constitutivo do seu direito, enquanto ao réu incumbe a prova dos fatos impeditivos, extintivos e modificativos que alega.

No caso, é inegável que o fato constitutivo ao direito vindicado na inicial (pagamento de horas extras) é a prestação de trabalho extraordinário e, em princípio, pela regra geral do art. 333 do CPC e 818 da CLT, ao reclamante incumbia o encargo probatório em relação à jornada extraordinária alegada.

Ocorre, porém, que se deve atentar ao princípio da distribuição dinâmica do ônus da prova, que pode levar a sua inversão. A doutrina indica que é possível inverter o ônus da prova (isto é, passar ao réu o encargo probatório relativamente ao fato constitutivo, cujo encargo inicialmente incumbia ao autor) desde que haja, além de 
outros, a incidência do princípio de "aptidão para a prova", do princípio da "préconstituição da prova" e aplicação dos princípios do Direito do Trabalho.

Relativamente à jornada de trabalho, há norma na CLT que prevê a "préconstituição da prova". É justamente o art. $74, \S 2^{\circ}$, da CLT, que "Para os estabelecimentos de mais de dez trabalhadores será obrigatória a anotação da hora de entrada e de saída, em registro manual, mecânico ou eletrônico, conforme instruções a serem expedidas pelo Ministério do Trabalho, devendo haver préassinalação do período de repouso".

Portanto, é certo que os registros de horário se constituem na prova pré-constituída em relação à jornada de trabalho, cuja manutenção a lei impõe para os empregadores com mais de dez empregados. É por isso que se dá a inversão do ônus da prova, com presunção relativa de veracidade da jornada apontada na petição inicial, quando o empregador não traz aos autos os registros de horário a que estava obrigado por força do art. $74, \S 2^{\circ}$ da CLT, nos termos do item I da SJ 338 do TST.

O caso, entretanto, é inusitado, porque há discussão quanto ao ônus da prova em relação a fato que deve ser elucidado para fins de definir o encargo probatório em relação ao fato constitutivo do direito. Em outras palavras, é imperioso, primeiramente, saber se a reclamada (empregadora do reclamante) possuia ou não mais de dez empregados. O esclarecimento deste fato é fundamental para se verificar da possibilidade ou não da inversão do ônus da prova quanto à jornada de trabalho. Se a reclamada possuía mais de 10 empregados, inverte-se o encargo probatório a ela, pela aplicação do princípio da "pré-constituição da prova", exigida pelo $\S 2^{\circ}$ do art.74 da CLT, nos termos do item I da SJ 338 do TST, como já se viu. Já se possuía dez ou menos empregados, o encargo probatório quanto as horas extras alegadas na petição inicial permanece com o reclamante.

Não há, porém, prova nos autos que esclareça se a reclamada possuía ou não mais de dez empregados. E, não havendo prova deste fato, impõe-se, acerca do mesmo, decidir por presunção conforme o ônus da prova, isto é, decidir desfavoravelmente à parte que detém este encargo. $\mathbf{E}$, no caso em exame, de quem era este encargo?

Reponde-se: Pela aplicação do princípio geral da distribuição dinâmica do ônus da prova e, especificamente pela incidência do princípio da "aptidão para a prova", conclui-se que, no caso, à reclamada empregadora é que detinha este encargo. Isso porque não se pode negar que o dever de documentação relativamente aos seus empregados está a cargo do empregador e, em contrapartida, na espécie, vislumbra-se muita dificuldade do reclamante quanto a prova do número de empregados da reclamada.

Observa-se, ainda, que o reclamante desde a inicial requereu que a reclamada trouxesse aos autos toda a documentação alusiva ao vínculo laboral, sobretudo os comprovantes de início e fim das jornadas, sob pena de confissão ficta, referência que indica o fato de que a reclamada tem (ou tinha, já que falida) mais de dez empregados.

Assim, definido que a reclamada, ex-empregadora, é que deveria ter comprovado que possui dez ou menos empregados e, como deste encargo não de desincumbiu, a presunção é que possui mais de dez, atraindo a incidência do $\S 2^{\circ}$ do art. 74 da CLT.

Em decorrência, omitindo-se a reclamada em juntar nos autos os registros de horário a que estava obrigada, por força desta norma consolidada, como já se disse 
anteriormente, também ocorre a inversão do ônus de prova em relação à jornada de trabalho, com a presunção relativa de veracidade da jornada laboral apontada na petição inicial, conforme entendimento consubstanciado na Súmula do TST $\mathrm{n}^{\circ}$ 338, inciso I.

Veja-se que o exame feito pela Julgadora da origem com relação à obrigatoriedade ou não de a primeira reclamada manter registro de horário não implica julgamento extra petita, pois tal definição foi tomada por ela como prejudicial ao exame do pedido de horas extras formulado pelo reclamante.

Ademais, as referências lançadas na contestação de exercício do cargo de supervisor pelo reclamante ou a existência de viagens também não teriam o condão de afastar a observância legal à preconstituição da prova, pois tais fatos por si só não impediriam o controle da jornada pelo empregador, necessitando serem cabalmente comprovados nos autos para que se pudesse cogitar de regra de exceção do art. 62 da CLT.

Portanto, como já referido, aplicando-se o teor da SJ 338, I, do TST, tem-se por verdadeiras as jornadas declinadas na petição inicial, naquilo em que a prova dos autos não as contrariar" 374

- Acórdão do Tribunal Regional do Trabalho de Minas Gerais:

"EMENTA: INVERSÃO DO ÔNUS DA PROVA. TÉCNICA DE JULGAMENTO. Dispondo uma das partes de documentos cujo porte e manutenção são obrigatórios, o dever de exibição dos mesmos é integralmente seu. Todavia, verificando o Juiz do Trabalho que os mesmos não merecem a menor credibilidade, eis que totalmente divorciados do usual, a simples oferta do meio probatório não o desonera. $\mathbf{E}$ considerando-se a maior aptidão de uma das partes para a produção da prova, o que a doutrina qualifica como distribuição dinâmica do ônus da prova, temos como conseqüência que tal encargo permaneça com o empregador, em virtude dos fatos excepcionais que apontou. Afinal o ordinário se presume e o extraordinário deve ser provado, não obstante os ditames do art. 818/CLT. Destarte, se os cartões de ponto deixam de mostrar qualquer variação horária ao longo dos dias neles retratados, fato que foge absolutamente da realidade, há inexorável deslocamento do ônus probatório, com sua inversão, de modo a que o empregador comprove que a jornada constante dos documentos é verdadeira, sob pena de, ante o insucesso, ver-se condenado a satisfazer o pedido correlato. ${ }^{375}$

\footnotetext{
${ }^{374}$ Trecho do Acórdão do Processo no. 0077100-70.2007.5.04.0027 (RO), de relatoria do Desembargador Hugo Carlos Scheurmann em data de 19/03/2009. Disponibilização e verificação de autenticidade no site www.trt4.jus.br. Consulta ao site do Tribunal Regional do Trabalho do Rio Grande do Sul em 14/12/2010.

375 Trecho do Acórdão do Processo no. 0086500-42.2009.5.03.0003 (RO), de relatoria Juiz convocado Vitor Salino de Moura Eça em data de 24/05/2010. Disponibilização e verificação de autenticidade no site www.trt3.jus.br. Consulta ao site do Tribunal Regional do Trabalho de Minas Gerais em 14/12/2010.
} 
- Acórdão do Tribunal Regional do Trabalho do Piauí:

\begin{abstract}
“CERTIDÃO DE JULGAMENTO:
(...) MÉRITO: (...) Das horas extras - A recorrente também impugna a condenação em horas extras. Insiste em que o ônus da prova é do autor, por ser fato constitutivo do seu direito. Argumenta que a inversão do ônus probatório levada a efeito pelo juízo não prosperar. Requer ao final a improcedência da pretensão. $\mathrm{O}$ juízo a quo inverteu o ônus da prova (art. $6^{\circ}$, VIII, do CDC, subsidiariamente aplicado), em razão de a reclamada não ter cumprido integralmente a determinação de juntada de documentos relacionados à prestação de serviços de reparo e atendimento pelo reclamante, considerados de suma importância para a solução do litígio. Sem razão a reclamada. O ônus da prova da jornada extraordinária, em regra, é do autor. No entanto, no caso dos autos, a inversão do ônus da prova se impõe em face da juntada pela reclamada de cartões de ponto que veiculam horários uniformes, devendo prevalecer a jornada declinada na inicial se o empregador não fizer a contraprova, nos precisos termos da Súmula 338 do TST. O sistema estático de distribuição do ônus da prova veiculado pelo art. 333 do CPC não pode ser aplicado mecanicamente a todas as hipóteses concretas, pela simples subsunção do fato à norma, sob pena de haver afastamento do objetivo fundamental do processo que é uma prestação jurisdicional justa. Com efeito, a doutrina moderna tem lecionado que o ônus da prova é dinâmico e não mais estático. Assim, expedientes como o princípio da aptidão para a prova, princípio da comunhão da prova, inversão do ônus da prova devem ser ponderados no caso concreto, sempre tendo em vista o ideal de justiça do caso concreto. Portanto, e para terminar, na hipótese dos autos, invertido o ônus da prova, deve prevalecer a jornada da inicial, salvo se o reclamado se desincumbir do seu ônus. O reclamado não se desincumbiu do seu ônus. Aliás, as provas nos autos favorecem a versão do reclamante (depoimento testemunhal à fl. 245 e boletins de atendimento e de ocorrência às 217/243). Mantenho a sentença. (...)." 376
\end{abstract}

O Estado do Pará também apresenta decisões aplicando o ônus dinâmico da prova, como se percebe do trecho da sentença proferida nos autos do processo $\mathrm{n}^{\circ}$ : 1517-2009106-08-00-8 oriundo da Vara do Trabalho de Castanhal datada de 10/03/2010, em que trata o princípio da aptidão da prova como sinônimo da teoria da distribuição dinâmica do ônus da prova, a seguir transcrito:

376 Disponibilização e verificação de autenticidade no site www.trt22.jus.br. Consulta ao site do Tribunal Regional do Trabalho da $22^{\mathrm{a}}$ Região em 14/12/2010. 
“(...) Quanto ao salário família, recai sobre o empregador o ônus de provar de o empregado não lhe forneceu a documentação pertinente, já que é quem tem maiores condições de fazer tal demonstração, porquanto detentor natural da documentação atinente ao contrato de trabalho (princípio da aptidão para a prova ou teoria da distribuição dinâmica do ônus probatório). Na espécie, pelo reconhecimento do vínculo e em razão do argumento acima, julgo procedente o pedido de salário família."

Decisão interessantíssima também foi prolatada pelo TRT/15 $5^{\mathrm{a}}$ Região no processo $n^{\circ}$ 00537-2006-095-15-00-9, decisão unânime $n^{\circ}$ 026472/2007, publicada em 15/06/2007), cujas razões seguem transcritas:

"De considerar que a visão estática da distribuição do ônus da prova, turvou-se já, sendo que, de maneira muito límpida, nos dias que correm, há dar proeminência ao modo de ver que redunda na idéia da distribuição dinâmica do onus probandi: deve atendê-lo quem está em melhores condições e/ou possibilidades de produzir a prova, o que há de ser estabelecido atento ao caso concreto e não de maneira vaga e abstrata (também superficial?), antecipadamente fixada, o que, não raras vezes, acaba por ignorar a realidade, a palpitação e as incontáveis variações que a complexidade da vida hodierna provoca, refletindo, como é palmar, de maneira negativa no processo e na distribuição da Justiça, com o que, por óbvio, não se pode concordar.

Quanto a esse tópico, por derradeiro, há observar que a tese da recorrente implica em sustentar ela, uma financeira, que não sabe quem trabalha (rectius: circula), por suas dependências, rotineiramente, o que, atento ao seu produto e finalidade social, não corresponde, em absoluto, ao "quod plerumque accidit", ao que normalmente acontece, de maneira que, se de fato ocorreu, só pode ser atribuído à sua incúria!"

Trata-se na hipótese supra transcrita justamente de um caso de terceirização de mão-de-obra, admitindo pois o julgador a aptidão da empresa tomadora da mão-de-obra para a prova relativa à própria prestação de serviços. 
Para demonstrar a possibilidade de aplicação do ônus dinâmico da prova em face de execução do processo segue trecho de aresto jurisprudencial ainda da $15^{\mathrm{a}}$ Região relativo à matéria da impenhorabilidade do bem de família e a prova das condições legais para seu reconhecimento:

\begin{abstract}
"Ora, no caso em exame, o bem é a própria residência dos sócios executados até que se prove o contrário (e não o inverso). Não podem os agravantes fazer prova negativa de fatos suscitados, ou seja, tirarem certidão negativa de todos os cartórios do país, para comprovar que aquele é seu único bem imóvel. Tolerar tal meio de prova trata-se de um arremedo de jurisdição, ultrajando o princípio constitucional do acesso à justiça. Assim, já que alega o agravado que este bem não é o único imóvel dos executados, cabia a ele, pela distribuição dinâmica do ônus da prova, demonstrar de forma robusta que não se trata do último bem residencial.

Aliás, não se pode esquecer que a moradia foi erigida a princípio constitucional, sendo um dos alicerces da dignidade da pessoa humana, vetor central do Estado Democrático de Direito. Não é porque houve uma vitória em demanda de cunho trabalhista, que se pode reduzir o alter a uma condição abaixo do que é o mínimo condigno de uma vida regular, dentro daquilo que se conhece como patamar mínimo civilizatório ou mínimo existencial, internos ao núcleo intangível da dignidade da pessoa humana.",377

Demais disto, vê-se dos autos que os agravantes juntaram suas declarações de imposto de renda, constando o imóvel penhorado como o único. Ainda mais, para solver demais processos trabalhistas, outros três bens imóveis foram praceados e arrematados, restando este discutido como o único pertencente ao casal.
\end{abstract}

A teoria dinâmica do ônus da prova igualmente é apta à solução de questões em matéria de acidente de trabalho. Novamente segue entendimento exarado no Tribunal Regional do Trabalho de Campinas a propósito do ônus dinâmico da prova como forma de atribuição do encargo à empresa quanto às condições do ambiente de trabalho:

“(...) Em segundo lugar, ressalta-se que é ônus do reclamante comprovar o fato constitutivo do seu direito e é ônus da reclamada comprovar o fato modificativo do direito do reclamante, nos termos dos artigos 818, da Consolidação das Leis do

\footnotetext{
${ }^{377}$ PROCESSO TRT $15^{\mathrm{a}}$ REGIÃO No 475-2009-082-15-00-1.AGRAVO DE PETIÇÃO EM EMBARGOS DE TERCEIROS - $6^{\mathrm{a}}$ TURMA - $12^{\mathrm{a}}$ CÂMARA. ${ }^{\circ}$ AGRAVANTE: ARMANDO HUGO SILVA Embargante/terceiro) $2^{\text {a }}$ AGRAVANTE: LEYLA APARECIDA RANGEL SILVA (Embargante/terceiro) AGRAVADO: PEDRO DONIZETE LOPES (Embargado/reclamante) ORIGEM: $3^{\text {a }}$ VARA DO TRABALHO DE SÃO JOSÉ DO RIO PRETO (Sandra Maria Zirondi)
} 
Trabalho, e 333, do CPC. No caso específico do acidente do trabalho ou doença ocupacional, cabe ao autor demonstrar o dano, qual seja, a redução da sua capacidade de trabalho, ao passo que à reclamada cabe demonstrar que cumpriu sua obrigação legal de garantir ao trabalhador um ambiente de trabalho sadio, reduzindo os riscos inerentes ao trabalho (artigo $7^{\circ}$, XXII, da Constituição Federal).

Além dessas regras básicas, deve-se ter em mente também as condições que cada parte tem para produzir determinada prova - critério que norteia a chamada "teoria de distribuição dinâmica do ônus da prova" ${ }^{378}$. Este critério adicional de apreciação da prova nada mais é do que a concretização processual do princípio da ampla defesa, que orienta o julgador a não exigir da parte prova negativa ou prova impossível. Nesse passo, observa-se que o empregador dispõe de amplas condições para provar que propiciou ao empregado um ambiente de trabalho sadio, enquanto, para o empregado é árdua a prova de que o empregador foi negligente com suas obrigações." (negritei) ${ }^{379}$

Registre-se, por fim, decisão monocrática recente da Corregedoria do Tribunal Regional do Trabalho de Campinas proferida em reclamação correicional $\mathrm{N}^{\mathrm{o}}$ 0000614-52.2010.5.15.0053 publicada em 04/11/2010 ajuizada contra decisão de primeiro grau que determinara inversão do ônus da prova a partir de presunção relativa. No caso não foi admitida a correição parcial em face da decisão que realizou distribuição dinâmica do ônus da prova de forma fundamentada e com ciência à parte. Segue parte da decisão:

\footnotetext{
378 in Indenizações por Acidente do Trabalho ou Doença Ocupacional, Sebastião Geraldo de Oliveira, pg. 201, Ed. LTr, $5^{\text {a }}$ Edição

${ }^{379}$ PROCESSO TRT/15 a REGIÃO N. ${ }^{\text {o }}$ 0084400-05.2005.5.15.0106,RECURSO ORDINÁRIO,RECORRENTE : TECELAGEM SÃO CARLOS S.A..RECORRIDO: BRADESCO SEGUROS S.A.,RECORRIDO : TANIA REGINA BATISTA, ORIGEM: $2^{\text {a }}$ VARA DO TRABALHO DE SÃO CARLOS
} 
"Insurge-se a corrigente contra decisão (...) que determinou a inversão do ônus da prova, presumindo verdadeiras as condições de periculosidade narradas na inicial, apresentada pela parte reclamante, impondo à reclamada, ora denominada corrigente, a realização de prova técnica de contraposição, suficiente a infirmar a presunção relativa então declarada, haja vista que a corrigente não teria concordado em efetuar o depósito de honorários prévios, de sua parte, que seria no importe de $\mathbf{R} \$ 300,00$, mesmo tendo o nobre magistrado elucidado que a parte do reclamante seria solicitada junto a este E. TRT.

Diz a corrigente, que o MM. Juiz corrigendo deveria ter acolhido seu pedido de produção de prova emprestada, a despeito da falta de anuência da parte contrária, porque este procedimento além de mais célere, seria-lhe menos oneroso, devendo, portanto, ser empregado nos autos originais.

(...)Assim, o MM. Juízo corrigendo, ao considerar, a uma, que o E. TST já teria pacificado entendimento de que é direito líquido e certo do empregador não realizar depósito de honorários prévios, daí porque não determinou à corrigentereclamada que efetuasse tal depósito; a duas, que o processo não poderia ficar estagnado; a três, que esta Especializada não possuia corpo de peritos em seu quadro funcional; a quatro, que não se poderia obrigar que um perito particular nomeado trabalhasse às suas custas, apenas com a expectativa de recebimento final; a cinco, que seria defeso ao Juízo inviabilizar o pleno acesso a Justiça, pela impossibilidade prática da prova técnica; a seis, que de forma prática, a corrigentereclamada seria a parte com condições financeiras de viabilizar a prova pericial nos autos principais, que não seria realizada, como de costume, por intermédio de perito nomeado para tal encargo pelo MM. Juízo corrigendo, diante do comportamento obstativo e não colaborativo com a Justiça, demonstrado pela corrigente; VISLUMBROU, conforme seu entedimento, que outra alternativa não lhe restara, diante das nuances do caso concreto, senão inverter o ônus da prova, com base na teoria do ônus da prova dinâmico. Pontua-se, que o MM. Juiz corrigendo ao inverter o ônus da prova, além de fazê-lo em audiência, dando ciência imediata à corrigente, ainda resguardou seu direito de realização de prova técnica de contraposição, suficiente a infirmar a presunção relativa então declarada.

(...) Posto isto: Julgo INCABÍVEL a medida correicional em exame.

\section{(...)FLAVIO \\ ALLEGRETTI \\ DE CAMPOS COOPER,}

Desembargador Corregedor Regional"

Em que pese quantitativamente poucos ainda ${ }^{380}$ os pronunciamentos da jurisprudência trabalhista no tema da distribuição dinâmica do ônus da prova, são

\footnotetext{
${ }^{380}$ Por óbvio, foram pesquisados e encontrados outros pronunciamentos jurisdicionais aplicando a teoria dinâmica do ônus da prova, não sendo trazidos todos a colação por não se tratar de espaço de repertório jurisprudencial. Assim, a opção se fez por uma pequena amostragem para verificar a aplicação prática do ônus dinâmico da prova.
} 
qualitativamente expressivos, permitindo inclusive a extração, como visto, de fundamentos e critérios de aplicabilidade dessa teoria ao processo do trabalho.

\subsection{Os Enunciados aprovados na $1^{\text {a }}$. Jornada de Direito Material e Processual na Justiça do Trabalho}

Por ocasião da $1^{\text {a }}$ Jornada de Direito Material e Processual na Justiça do Trabalho que aconteceu no Tribunal Superior do Trabalho e foi promovida pela em conjunto com a Associação Nacional dos Magistrados da Justiça do Trabalho, Escola Nacional de Formação e Aperfeiçoamento de Magistrados (ENAMAT) e com o apoio do Conselho Nacional das Escolas de Magistratura do Trabalho (CONEMATRA), foram editados 79 enunciados que embora não sejam dotados de qualquer efeito legal ou vinculante, servem para expressar os posicionamentos dos juízes do trabalho em nível nacional nos mais diversos temas. Interessa ao tema do trabalho especialmente o seguinte Enunciado ${ }^{381}$ :

\section{ENUNCIADO 60. INTERDIÇÃO DE ESTABELECIMENTO E AFINS. AÇÃO DIRETA NA JUSTIÇA DO TRABALHO. REPARTIÇÃO DINÂMICA DO ÔNUS DA PROVA.}

I - A interdição de estabelecimento, setor de serviço, máquina ou equipamento, assim como o embargo de obra (artigo 161 da CLT), podem ser requeridos na Justiça do Trabalho (artigo 114, I e VII, da CRFB), em sede principal ou cautelar, pelo Ministério Público do Trabalho, pelo sindicato profissional (artigo $8^{\circ}$, III, da CRFB) ou por qualquer legitimado específico para a tutela judicial coletiva em matéria labor-ambiental (artigos $1^{\circ}$, I, 5 $5^{\circ}$ e 21 da Lei 7.347/85), independentemente da instância administrativa.

II - Em tais hipóteses, a medida poderá ser deferida [a] "inaudita altera parte”, em havendo laudo técnico preliminar ou prova prévia igualmente convincente; [b] após audiência de justificação prévia (artigo 12, caput, da Lei 7.347/85), caso não haja laudo técnico preliminar, mas seja verossímil a alegação, invertendo-se o ônus da prova, à luz da teoria da repartição dinâmica, para incumbir à empresa a demonstração das boas condições de segurança e do controle de riscos. (g.n.)

\footnotetext{
${ }^{381}$ Enunciados disponíveis no sítio http://www.anamatra.org.br/jornada/enunciados/enunciados_aprovados.cfm . Última consulta em 14/12/2010
} 
O Enunciado 60 prevê expressamente a aplicação da teoria do ônus dinâmico da prova ao se atribuir à empresa o encargo da prova quanto ao meio ambiente de trabalho seguro. Originou-se de proposta do juiz e professor Guilherme Guimarães Feliciano, um dos doutrinadores do processo trabalhista que já vinha admitindo o uso da teoria no processo do trabalho. Segundo o autor é "notoriamente mais fácil à empresa fazer a prova das condições de segurança e saúde de seu estabelecimento, setor, máquina, equipamento ou obra, a repartição dinâmica do ônus da prova impor-lhe-á a incumbência dessa prova, corrigindo o curso das diversas teorias procedimentalistas (LEO ROSENBERG) que originaram, historicamente, "uma insuficiência metódica quanto à distribution of the risk of non persuasion or burden of proof in proceeding envolving Basic Constitucional Rights" 382.

Considerando a aprovação do Enunciado como proposto pelo autor verificase a abertura do caminho para novas perspectivas acerca do ônus da prova.

Há ainda outro Enunciado, o de número 2 que embora não se refira ao ônus dinâmico da prova propõe a inversão do encargo probatório a favor da parte que alega ofensa a direitos fundamentais ou princípios constitucionais o que vem de encontro a toda a ordem de justificativa teórica da dinamização do ônus probatório no processo do trabalho. Segue o enunciado transcrito em parte:

ENUNCIADO 2. DIREITOS FUNDAMENTAIS - FORÇA NORMATIVA. III - LESÃO A DIREITOS FUNDAMENTAIS. ÔNUS DA PROVA. Quando há alegação de que ato ou prática empresarial disfarça uma conduta lesiva a direitos fundamentais ou a princípios constitucionais, incumbe ao empregador o ônus de provar que agiu sob motivação lícita. (g.n.)

Em suma, o que se percebe seja das manifestações da jurisprudência seja dessas novas idéias propostas nos enunciados supra mencionados, é a insatisfação com as normas de distribuição estática do ônus da prova que desconsideram as diferenças

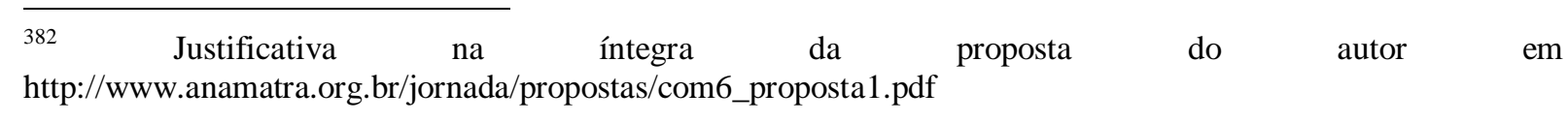


patrimoniais e pessoais reconhecidamente existentes na relação jurídica trabalhista e assim sendo passam ao largo no que respeita à resolução de questões impostas pela dinâmica do viver.

Paradigmáticas, portanto, essas novas visões ainda que esparsas, mas já demonstrando a mudança do por vir. 


\section{CONCLUSÃO}

O objetivo deste trabalho foi o de possibilitar a compreensão da aplicação de teoria do ônus dinâmico da prova no processo do trabalho a partir do reconhecimento da necessidade de superação das técnicas convencionais de distribuição dos encargos probatórios previstas no art.818 da Consolidação das Leis do Trabalho e no art.333 do Código de Processo Civil.

O imperativo de mudança teve origem justamente a partir da constatação pelos intérpretes do direito processual do trabalho de que as regras legais positivadas quando manuseadas muitas das vezes levavam a resultados opostos aos pretendidos pelas necessidades da tutela jurisdicional ao caso concreto, não produzindo sequer efeitos em conformidade com o ideário do direito material afetado. Percebeu-se que o encargo da prova quando suportado, por determinação das regras legais, pela parte que não teria condições dele se desincumbir, poderia ao final representar ofensa a princípios constitucionais da magnitude do próprio acesso à justiça.

Com efeito, reconhece-se no início do trabalho que o direito processual constitucional traça as linhas fundamentais do processo e este como instrumento ético, impõe especial relevância ao direito de acesso à justiça e ao devido processo legal, o que só pode ser adequadamente obtido com a superação dos parâmetros políticos liberais. De fato essa conotação liberal é atribuída às próprias regras distributivas do encargo da prova como positivadas contemporaneamente, sendo imperativa a sua superação em especial no processo trabalhista.

As garantias constitucionais do processo é que permitem inclusive ao juiz a partir do contraditório, da ampla defesa, da proclamação da igualdade substancial, criar o ambiente próprio à participação no processo e por meio dele, a realização da democracia na construção do direito aplicado ao caso concreto. 
A apreensão, ainda, do direito ao ônus da prova atribuído equanimamente como desdobramento do devido processo legal e como elemento de garantia constitucional de ação e da ampla defesa, pode ser considerado como fundamento autorizador do redimensionamento do encargo da prova com vistas à efetiva concretização do direito material do trabalhador a partir da garantia de sua igualdade substancial (e não apenas formal) no processo trabalhista.

Uma primeira ordem conclusiva a que chegamos se dá no sentido de que o processo do trabalho perspectivado sob a ótica da Constituição e dos direitos e princípios constitucionais deve conter estruturas que possibilitem a concretização dos direitos fundamentais dos trabalhadores.

Para tanto será imprescindível a ampliação de hipóteses de modificação do ônus da prova e até mesmo sua atribuição original àquela parte que tradicionalmente não deteria tal encargo considerando-se essencialmente o direito fundamental à tutela judicial efetiva do direito material em xeque.

Essa relativização das regras estáticas de distribuição da carga da prova foi apreciada no capítulo segundo, especialmente sob a perspectiva da necessária relevância atribuída à dimensão subjetiva do ônus e não menos certo do reconhecimento do aumento dos poderes instrutórios do juiz de modo que ambas as concepções não se excluem mas criam ambiente harmônico e propicio à consecução da missão do Estado Democrático de Direito especialmente no que toca à promoção da igualdade substancial das partes na relação jurídicoprocessual trabalhista.

Considerando-se a moderna visão de devido processo legal (justo), que imprescinde da igualdade substancial das partes, importa concluir que o magistrado enquanto interprete da lei e sujeito ativo no processo tem o dever constitucional de manifestar-se acerca do encargo probatório determinando-o, invertendo-o ou o modificando quando presentes obstáculos capazes de interferir profundamente na capacidade de produção probatória. De 
fato, de nada adiantaria conferir direitos sem a correspondente possibilidade aos seus titulares do pleno exercício dos mesmos, o que gera influxos inclusive na questão probatória. Isto porque o direito à prova é também direito fundamental ainda que implícito e que demanda sua realização por meio da conferência aos sujeitos processuais de meios aptos à demonstração dos fatos invocados para a comprovação do direito material controvertido.

Logo, insistir na abordagem da sistemática probatória no processo trabalhista sob uma moldagem clássica significa o alheamento à realidade do caso concreto, com manutenção do status quo patrimonial em razão da prova insuficiente de um dos sujeitos, geralmente o hipossuficiente na relação processual. Essa percepção via de consquência poderá conduzir a julgamentos divorciados daquela realidade substancial, inviabilizando a própria concretização do direito daquele que tem razão.

Sob este prisma a teoria dinâmica do ônus da prova ao superar a divisão estática do ônus da prova e conferir ao magistrado a tarefa de sua atribuição conforme a situação do caso concreto e a partir de diretrizes que reportam à igualdade substancial das partes, importa em melhor técnica processual adequada aos escopos do direito do trabalho.

Numa outra ordem conclusiva temos, ao final, que no processo do trabalho não se apresentam óbices à superação da teoria estática do ônus da prova. Ao contrário, tratase de ramo processual propício a implementação da dinamização da carga probatória na medida em que aprioristicamente os sujeitos da relação processual neste ramo especializado são substancialmente desiguais e normalmente um deles não é imune a uma série de fatores externos adversos que podem comprometer sua capacidade probatória.

Inclusive a interpretação do art.818 da Consolidação das Leis do Trabalho como norma processual aberta representa outro meio legitimador da adoção da teoria dinâmica do ônus da prova, ou seja, esta última acaba por conferir sentido constitucional ao dispositivo celetista ao complementá-lo com os valores da igualdade substancial, do direito fundamental à prova, do acesso à ordem jurídica justa. 
Por fim a atribuição dinâmica do ônus da prova no processo do trabalho atende ao sentido constitucional contemporâneo, impondo-se, tendencialmente como regra excepcional, a exigir fundamentação nos autos e em momento apto à observância, ela própria dos princípios constitucionais do contraditório e ampla defesa que caracterizam o devido processo substancial. 


\section{BIBLIOGRAFIA CONSULTADA}

ALEXY, Robert. Teoria de los derechos fundamentales. $2^{\mathrm{a}}$.Reimpr. Madrid: Centro de Estudios Constitucionales, 2001

ALMEIDA, Cleber Lúcio. Princípios de Direito Processual do Trabalho e o Exame dos

Reflexos das Recentes Alterações do Código de Processo Civil no Direito Processual do Trabalho. In: CHAVES, Luciano Athayde (org.) Direito Processual do Trabalho: Reforma e Efetividade. São Paulo: LTr, 2007

ALMEIDA, Isis de. Manual de Direito Processual do Trabalho. São Paulo: LTr, 1997.

AIRASCA, Ivana María. "Reflexiones sobre la doctrina de las Cargas Probatorias Dinámicas. In.:PEYRANO, Jorge W.(dir.); LÉPORI WHITE, Inês (coord.). Cargas probatorias dinámicas. Buenos Aires: Rubinzal-Culzoni, 2004.

ARAZI, Roland. La prueba en el proceso civil. $2^{\mathrm{a}}$ edição. Buenos Aires: Ediciones La Rocca, 1998

ARENHART, Sérgio Cruz. Ônus da prova e sua modificação no processo civil brasileiro. Revista Jurídica Notadez. Porto Alegre/RS, n. 343, p. 25-60, maio 2006

AZÁRIO, Márcia Pereira. Dinamização da Distribuição do ônus da prova no processo civil brasileiro. Tese (Mestrado), Faculdade de Direito, Universidade Federal do Rio Grande do Sul, 2006

BADARÓ, Gustavo Henrique Righi Ivahy. Ônus da prova no processo penal. São Paulo: Ed. Revista dos Tribunais, 2003 
BARACAT, Edgar J. "Estado actual de la teoria de la carga dinámica de la prueba com especial referencia a antecedentes jurisprudenciales y a la materia juzgada". In.: PEYRANO, Jorge W.(dir.); LÉPORI WHITE, Inês (coord.). Cargas probatorias dinámicas. Buenos Aires: Rubinzal-Culzoni, 2004.

BARBERIO, Sergio José. Cargas probatórias dinámicas. Qué debe probar El que no pude probar? In.: PEYRANO, Jorge W.(dir.); LÉPORI WHITE, Inês (coord.). Cargas probatorias dinámicas. Buenos Aires: Rubinzal-Culzoni, 2004.

BARBOSA MOREIRA, Carlos Roberto. Notas sobre a inversão da ônus da prova em benefício do consumidor. In: Revista de Processo. São Paulo:Revista dos Tribunais, no. 86, p.295-309, abr./jun.1997

BARBOSA MOREIRA, José Carlos. Alguns problemas atuais da prova civil In Temas de Direito Processual: quarta série. Saraiva, 1988, pg. 145

A função social do processo civil moderno e o papel do juiz e das partes na direção e instrução do processo. In Revista de Processo São Paulo no. 37, jan/março de 1985 p.146-147

.O juiz e a prova. In Revista de Processo São Paulo, no. 35, abril/junho de 1984 p.178184

.Julgamento e ônus da prova. In Temas de Direito Processual: segunda série. Saraiva, 1988.p. 73-82

.La igualdad de las partes em proceso civil. In Temas de Direito Processual: quarta série. Saraiva, 1989 pg.67-81

Alguns problemas atuais da prova civil. In Temas de Direito Processual: quarta série. Saraiva, 1988, pg. 145 
.A função social do processo civil moderno e o papel do juiz e das partes na direção e instrução do processo. In Revista de Processo São Paulo , no. 37, jan/março de 1985 p.146147 .

BARROS, Sérgio Resende. Direitos Humanos: paradoxo da civilização. Belo Horizonte:Del Rey, 2003.

BASTOS, Celso Ribeiro. Curso de direito constitucional. Rio de Janeiro: Saraiva, 1996.

BEBBER, Júlio César. Processo do Trabalho. Adaptação à Contemporaneidade. Tese (Doutorado), Faculdade de Direito, Universidade de São Paulo, 2009 Ônus da prova. Horas extras: breves considerações à nova redação da Súmula n. 338 do TST. LTR - Suplemento Trabalhista. São Paulo, n. 008, p. 33-34, 2004 . Influência da Personalidade do Juiz ao decidir. Revista LTr, 72. São Paulo, no.72, 2008

BEDAQUE, José Roberto dos Santos. Poderes instrutórios do juiz. São Paulo: Revista dos Tribunais, 2001 . Efetividade do processo e Técnica Processual. São Paulo: Malheiros, 2007 . Direito e Processo. São Paulo: Malheiros, 2001

BEGALLES, Carlos Alberto. Lições de direito processual do trabalho. São Paulo: LTr, 2005.

BRAGA, Sidney da Silva. Iniciativa Probatória do juiz no processo civil. São Paulo: Saraiva, 2004.

BRISELLI, Luiz Felipe Sampaio. A teoria da prova, o princípio protetor e as desigualdades materiais da relação de trabalho. Dissertação (Mestrado) - Faculdade de Direito. Universidade de São Paulo, São Paulo, 2008 
BRITO FILHO, José Cláudio Monteiro De, 1964-. A inversão do ônus da prova e o processo do trabalho. Revista do TRT - $8^{a}$ Região. Belém, v. 36, n. 71, p. 129-37, jul./dez. 2003

BOBBIO, Norberto. A era dos direitos. Trad. Carlos Nelson Coutinho. 9. ed. São Paulo: Ed. Campus, 1992.

BONAVIDES, Paulo.Curso de Direito Constitucional. 12.ed.São Paulo:Ed.Malheiros,2002.

BORGES, Leonardo. O novo CPC e a Constituição Federal. Cadernos da AMATRA IV. $14^{o}$. Caderno de Estudos sobre Processo e Direito do Trabalho. Porto Alegre, no. 14 - Novembro 2010, p.110/120

BUENO, Cássio Scarpinella. Curso sistematizado de direito processual civil: teoria geral do direito processual civil. vo.1. São Paulo: Saraiva, 2007. . Amicus Curiae no Processo Civil Brasileiro: um terceiro enigmático. São Paulo:2002

BRANDÃO, Cláudio . Acidente do Trabalho e Responsabilidade Civil do Empregador. São Paulo: Ed. LTr, 2006.

CALAMANDREI, Piero. Processo e democrazia. Padova: Cedam, 1954

CÂMARA, Alexandre Freitas. Lições de Direito Processual Civil vol.I. Rio de Janeiro: Lúmen Júris, 2009

- Doenças Preexistentes e ônus da prova: o Problema da Prova Diabólica e uma possível solução”. Revista Dialética de Direito Processual. São Paulo: Dialética, 2005, n.31

. A inversão do ônus da prova em favor do consumidor. Revista da EMERJ, v.5, n.18, 2002, p.88-103

CAMBI, Eduardo Augusto Salomão. A prova civil: admissibilidade e relevância. São Paulo: Editora Revista dos Tribunais, 2006 
. Direito Constitucional à Prova no Processo Civil. São Paulo: Editora Revista dos Tribunais, 2001.

- Divergência jurisprudencial: inversão do ônus da prova e o ônus de antecipar o pagamento dos honorários periciais. Revista dos Tribunais. São Paulo/SP, v. 804, p. 132-41, out. 2002

- Tese para o Encontro Estadual do Ministério Público do Paraná. Disponível em: www.ceaf.mp.pr.gov.br/arquivos/File/teses09/EduardoCambi1.pdf. Acesso em 13 de janeiro de 2010.

CANOTILHO, Jose Joaquim Gomes. Direito constitucional e teoria da Constituição. 3. ed. Coimbra: Almedina, 2002.

. Estudos sobre Direitos Fundamentais. 1ª Edição brasileira. São Paulo: RT, 2009.

CAPPELlETTI, Mauro. Processo, Ideologias e Sociedade. Vol. I [Trad] Elicio de Cresci Sobrinho. Porto Alegre: Fabris, 2008

CAPPELlETTI, Mauro; GARTH, Bryant. Acesso à Justiça. [Trad] Ellen Gracie Northfleet. Porto Alegre: Fabris, 1988

CARLESSO, Luciano Arlindo. Direito Humano a uma meio ambiente de trabalho ecologicamente equilibrado - um direito de todos os seres humanos e trabalhadores. LTr: revista legislação do trabalho, São Paulo, v. 72, n. 2, p. 209-220, fev. 2008.

CARBONE, Carlos Alberto. "Cargas Probatorias Dinámicas: una mirada al derecho comparado y novedosa ampliación de su campo de acción. In.: PEYRANO, Jorge W.(dir.); LÉPORI WHITE, Inês (coord.). Cargas probatorias dinámicas. Buenos Aires: RubinzalCulzoni, 2004. 
CÁRDENAS, Hector H. "Las Cargas Procesales Dinámicas en la ineficácia concursal. In.: PEYRANO, Jorge W.(dir.); LÉPORI WHITE, Inês (coord.). Cargas probatorias dinámicas. Buenos Aires: Rubinzal-Culzoni, 2004.

CARNELUTTI, Francesco. La prueba civil. Buenos Aires: Ediciones Depalma, 1982.

CARPES, Artur Thompsen. Prova e Participação no Processo Civil: Dinamização dos ônus probatórios na perspectiva dos direitos fundamentais. Tese (Mestrado), Faculdade de Direito, Universidade Federal do Rio Grande do Sul, 2008

.A distribuição dinâmica do ônus da prova no formalismo valorativo. Revista da AJURIS: doutrina e jurisprudência. Porto Alegre, v.33, n.104, p. 9-18, dez. 2006

CHIOVENDA, Giuseppe. Instituições de Direito Processual civil. [trad.] Paolo Capitanio. São Paulo: Quórum, 2009

CINTRA, Antonio Carlos; GRINOVER, Ada Pellegrini; DINAMARCO, Cândido Rangel. Teoria Geral do Processo. São Paulo: Editora Malheiros, 1995.

COLTRO, Antônio Carlos Mathias. A atividade judicial e a realização do direito. Revista da ESMESE, no.05, 2003.

COMPARATO, Fábio Konder. A afirmação histórica dos direitos humanos. São Paulo:Ed.Saraiva. 2005.

COMOGLIO, Luigi Paolo. Etica e tecnica del giusto processo. Torino: G. Giappichelli, 2004

CORREIA, Marcus Orione Gonçalves. Poder constitucional da ação, direitos sociais e Estado democrático de direito. 2000. Tese (Livre-Docência em Direito do Trabalho) - Faculdade de Direito. Universidade de São Paulo, São Paulo. Direito Processual Constitucional São Paulo: Saraiva, 1998. 
COUTURE, Eduardo Juan. Fundamentos Del Derecho Procesal Civil. $3^{\text {a }}$.ed. Buenos Aires: Roque Depalma, 1958

DALLEGRAVE NETO, José Affonso. Responsabilidade Civil no Direito do Trabalho. São Paulo: Ed. LTr, 2008.

DALL'AGNOL JUNIOR, Antonio Janyr. Distribuição Dinâmica dos Ônus Probatórios. Revista Jurídica, 137. Porto Alegre, no. 280, 2001

D'APONTE, Marcello. Violazione dei doveri di diligenza, responsabilità del laboratore e ripartizione dell'onere della prova. Il Diritto Del Lavoro. Roma, n. 1, p. b.15-20, gen./feb. 2001

DELGADO, Maurício Godinho. Curso de Direito do Trabalho. São Paulo: LTr, 2003.

DELL'ISOLA, Carmela. O ônus da prova e sua inversão no processo civil. São Paulo, 2001. Dissertação (Mestrado) - LFaculdade de Direito. Universidade de São Paulo, São Paulo.

DEVIS ECHANDÍA, Hernando. Teoria General De La Prueba Judicial. Buenos Aires: Zavalia, 1981.

DIDIER JR, Fredie. Curso de Direito Processual Civil vol.1. Teoria Geral do Processo e Processo de Conhecimento. Salvador: Juspodivm, 2009

DIDIER JR, Fredie; BRAGA, Paula Sarno; OLIVEIRA, Rafael. Curso de Direito Processual Civil vol.2. Salvador: Juspodivm, 2009

DINAMARCO, Cândido Rangel. Instituições de Direito Processual Civil. São Paulo: Ed.Malheiros, 2003. 
. A instrumentalidade do processo. São Paulo: Ed. Malheiros, 1993

.A nova era do processo civil. São Paulo: Ed. Malheiros, 2007.

DUARTE, Bento Herculano. Poderes do Juiz do Trabalho: direção e protecionismo processual. São Paulo: LTr, 1999.

. O princípio do "in dubio pro misero" como regra de ônus da prova.In.: PAMPLONA FILHO, Rodolfo Mário Veiga, 1972- (coord.); SILVA, Antônio álvares da (et Al.); BARROS, Alice Monteiro de (colab.). Processo do Trabalho: estudos em homenagem ao professor José Augusto Rodrigues Pinto. São Paulo: LTr, 1997.

FIX-ZAMUDIO, Hector. Constitución y proceso civil en Latinoamérica. México: UNAM, Instituto de Investigaciones Jurídicas, 1974

GARCÍA GRANDE, Maximiliano. Cargas Probatórias Dinâmicas: Ni nuevas, ni argentinas, ni aplicables. Disponível em derecho.org.ar/congresoprocesal/cargas\%20DinE1micas\%20grande_.pdf.Acesso em $12 / 12 / 2010$.

GIDI, Antônio. Aspectos da inversão do ônus da prova no Código de Defesa do Consumidor. Revista de Direito do Consumidor. São Paulo: Revista dos Tribunais, jan/mar/1997

GIGLIO, Wagner D. Direito Processual do Trabalho. São Paulo: Saraiva, 1997.

GODINHO, Robson Renault. A distribuição do ônus da prova na perspectiva dos direitos fundamentais. Revista da EMERJ. Rio de Janeiro, v. 10, n. 38, p. 263-84, abr./jun. 2007.

GOMES FILHO, Antônio Magalhães. Direito a prova no processo penal. São Paulo: Ed Revista dos Tribunais, 1997

GONZÁLEZ, Pérez Jesús. El derecho a la tutela jurisdiccional. Madrid: Cívitas, 1989 
GRECO, Leonardo. As provas no processo ambiental. Revista de Processo, no. 128. RT, outubro de 2005 .

GRECO FILHO, Vicente. Direito Processual Civil Brasileiro. São Paulo: Saraiva, 1996.

GRINOVER, Ada Pelegrini. Rumo a um Código Brasileiro de Processos Coletivos. In: MILARÉ, Edis (coord.) A Ação Civil Pública após 20 anos: efetividade e desafios. São Paulo: RT, 2005.

As garantias constitucionais do processo. Defesa, contraditório, igualdade e par condicio na ótica do processo de estrutura cooperatória. In Novas Tendências do Direito Processual (De acordo com a Constituição de 1988). Rio de Janeiro: Forense Universitária, 1990.

GUERRA FILHO, Willis Santiago. Processo constitucional e direitos fundamentais. São Paulo: Celso Bastos, 1999

FACCHINI NETO, Eugênio. “E o Juiz não é só de Direito...”. In: Zimerman, David, Coltro, Antônio Carlos Coltro (Org.). Aspectos Psicológicos na Prática Jurídica. Campinas: Editora Millennium, 2002.

FALCÓN, Enrique M. Tratado de La Prueba. Buenos Aires: Editorial Ástrea, 2003

FERNANDEZ NETO, Atahualpa. A desigualdade como critério de distribuição do ônus da prova. Revista do Ministério Público do Trabalho. Brasília/DF, n. 23, p. 121-28, mar. 2002

FELICIANO, Guilherme Guimarães. Distribuição dinâmica do ônus da prova no processo do trabalho - Critérios e Casuística. Revista do Tribunal Regional do Trabalho da $15^{a}$. Região, n.32, 2008, p.103-112. 
- Tutela processual dos direitos humanos nas relações de trabalho. Disponível em http://jus2.uol.com.br/doutrina/texto.asp?id=7810. Acesso em 7/11/2006

. Um olhar sobre o novo código de processo civil (PLS n.166/2010) na perspectiva das prerrogativas da magistratura nacional (especialmente na Justiça do Trabalho). Cadernos da AMATRA IV. 14 ${ }^{\circ}$. Caderno de Estudos sobre Processo e Direito do Trabalho. Porto Alegre, no. 14 - Novembro 2010, p.55-76.

FERREIRA FILHO, Manoel Gonçalves. Direitos fundamentais. São Paulo: Saraiva, 2000

FORNACIARI, Fernando Hellmeister Clito. Ônus da prova no processo civil. São Paulo, 2005. Dissertação (Mestrado) - Faculdade de Direito. Universidade de São Paulo, São Paulo.

GUASP, Jaime. Derecho procesal civil. 4. ed., revisada y adaptada a la legislación vigente por Pedro Aragoneses, tomo 1. Madrid: Civitas, 1998

GUNTHER, Luiz Eduardo. Aspectos principiológicos da execução incidentes no processo do trabalho. In: Execução Trabalhista: Homenagem aos 30 anos da AMATRA IX. Coord. José aparecido dos Santos. São Paulo: LTr, 2008,

HENRIQUES FILHO, Ruy Alves. Os direitos fundamentais na jurisdição constitucional e as cláusulas gerais processuais. Dissertação (Mestrado.Faculdade de Direito da Universidade Federal do Paraná. Curitiba,2006

HIGINO NETO, Vicente. Ônus da Prova. Teorias da Redução do Módulo da Prova e das Provas Dinâmicas e Compartilhadas. Curitiba: Juruá Editora, 2010.

HOBSBAWM, Eric. J. Mundos do Trabalho. [Trad] Waldea Barcellos e Sandra Bedran. São Paulo:Ed. Paz e Terra. 2005.

ITALA, Luigi de. Diritto Processuale Del Lavoro. Torino: Editrice Torine, 1966. 
KFOURI NETO, Miguel. Culpa médica e ônus da prova : presunções, perda de uma chance, cargas probatórias dinâmicas, inversão do ônus probatório e consentimento informado : responsabilidade civil em pediatria, responsabilidade civil em gineco-obstetrícia. São Paulo, Editora Revista dos Tribunais, 2002

KNIJNIK, Danilo. As (perigosíssimas) doutrinas do 'ônus dinâmico da prova' e da 'situação do senso comum' como instrumentos para assegurar o acesso à justiça e superar a probatio diabólica. Processo e Constituição: Estudos em Homenagem ao Professor José Carlos Barbosa Moreira. São Paulo: RT, 2006.

LEITE, Carlos Henrique Bezerra. Princípio da igualdade: repercussões no direito processual do trabalho. Revista do Direito Trabalhista. Brasília, n. 7, p. 19-22, jul. 2005 .O acesso à Justiça como Direito Humano e Fundamental. Revista Trabalhista Direito e Processo. São Paulo, no. 26 - abril/junho, 2008, p.21-28

LEITE, Carlos Henrique Bezerra, 1960-; MACHADO, Meireely Alvarenga. A nova portaria do MTE sobre registro eletrônico de ponto e a questão da inversão do ônus da prova. Revista IOB Trabalhista e Previdenciária. São Paulo, a. 21, n. 247, p. 7-16, jan. 2010.

LEGUISAMÓN, Hector E. La necesaria madurez de las cargas probatórias dinámicas.In.: PEYRANO, Jorge W.(dir.); LÉPORI WHITE, Inês (coord.). Cargas probatorias dinámicas. Buenos Aires: Rubinzal-Culzoni, 2004.

LÉPORI WHITE, Inês. Cargas Probatórias Dinámicas.In.: PEYRANO, Jorge W.(dir.); LÉPORI WHITE, Inês (coord.). Cargas probatorias dinámicas. Buenos Aires: RubinzalCulzoni, 2004.

LIMA, Alcides de Mendonça. Processo civil no processo trabalhista. São Paulo, Brasil: LTr, 1992 
LÓPEZ-MESA, Marcelo J. La carga de la prueba em ciertos casos de responsabilidad civil (La doctrina de las cargas probatórias dinâmicas em la jurisprudência argentina y española). Disponível em www.eft.com.ar/DOCTRINA/articulos/libros-carga_de_la_prueba. Acesso em 6/11/2007.

LÓPEZ-MIRÓ, Horacio G; CALANDRI, Laura Cristina [et al.]. Probar o sucumbir: los tres grados del convencimiento judicial y la regla procesal del onus probandi. Buenos Aires: Abeledo-Perrot, 1998

MACHADO JUNIOR, César Pereira da Silva. O ônus da prova no processo do trabalho. São Paulo: Ltr, 2001.

MALLET, Estêvão. Aplicabilidade das normas constitucionais relativas a direitos sociais. $L T r$ : revista legislação do trabalho, São Paulo, v. 55, n. 10, p. 1186-1190, out. 1991.

. Direito do Trabalho e discriminação. Revista da Amatra II São Paulo, São Paulo, v. 4, n. 10, p. 18-21, dez. 2003

.Discriminação e processo do trabalho. Revista do TST. Rio de Janeiro.V.65, n.1,p.148159 , out/dezembro/99, p. 154

MARINONI, Luiz Guilherme.Teoria geral do processo. São Paulo: Ed. Revista dos Tribunais, 2004

. Curso de Processo Civil. Vol. 1. São Paulo, Ed. RT.2007

.Técnica Processual e Tutela dos Direitos. São Paulo: Revista dos Tribunais, 2004

. Formação da convicção e inversão do ônus da prova segundo as peculiaridades do caso concreto. Revista dos Tribunais. São Paulo/SP, v. 862, p. 11-21, ago. 2007

$O$ direito à tutela jurisdicional efetiva na perspectiva da teoria dos direitos

fundamentais. Disponível em www.professormarinoni.com.br. Acesso em 10/12/2010.

.A antecipação da tutela. São Paulo: Malheiros, 2004, p.244 
MARINONI, Luiz Guilherme; ARENHART, Sérgio Cruz. Comentários ao Código de Processo Civil. São Paulo: Ed. Revista dos Tribunais, 2005 . Curso de Processo Civil. Vol. 2. São Paulo, Ed. RT.2007 .Manual do Processo de Conhecimento. São Paulo: Ed.Revisa dos Tribunais 2004 .Prova. São Paulo: Ed.Revisa dos Tribunais, 2010

MARQUES, José Frederico. Instituições de direito processual civil. Rio de Janeiro: Forense, 1966.

MARQUESAN, Ana Maria Moreira; STEIGLEDER, Annelise. Fundamentos jurídicos para a inversão do ônus da prova nas ações civis públicas por danos ambientais. Revista da AJURIS no.90. Porto Alegre, 2003.

MARTINS, Adalberto. Manual Didático de Direito Processual do Trabalho. 4ª Edição. Malheiros, São Paulo, 2008

MARTINS, Sérgio Pinto. Comentários às Orientações Jurisprudenciais da SBDI- 1 e 2 do TST. São Paulo: Atlas, 2009

.Direitos Fundamentais Trabalhistas. São Paulo: Atlas, 2008 - Ônus da prova relativo no processo do trabalho. Revista IOB Trabalhista $e$ Previdenciária. São Paulo, v. a. 17, n. 202, p. 7-14, abr. 2006. . Direito processual do trabalho. São Paulo: Atlas, 2000.

MEDINA, Paulo Roberto de Gouvêa. Direito processual constitucional. Rio de Janeiro: Forense, 2004.

MEIRELES, Edilton. Inversão do ônus da prova no processo trabalhista. GENESIS - Revista de Direito do Trabalho. Curitiba, n. 51, p. 313-21, mar. 1997 
MELO, Raimundo Simão de. Responsabilidade objetiva e inversão da prova nos acidentes de trabalho. Revista do TRT - 15 a REGIÃO. Campinas, n. 30, p. 79-100, jan./jun. 2007

MENDES, Aluisio Gonçalves de Castro. O Código Modelo de Processos Coletivos do Instituto Ibero-Americano de Direito Processual. Disponível na internet: http://www.mundojuridico.adv.br>. Acesso em 5 de janeiro de 2010.

MICHELI, Gian Antonio. La carga de la prueba. Buenos Aires: Ediciones juridicas EuropaAmerica, 1961

MILARÉ, Edis; CASTANHO, Renata. A distribuição do ônus da prova no Anteprojeto do Código Brasileiro de Processos Coletivos. In: GRINOVER, Ada Pellegrini Grinover; MENDES, Aluisio Gonçalves de Castro; WATANABE, Kazuo (coords.). Direito Processual Coletivo e o Anteprojeto de Código Brasileiro de Processos Coletivos.São Paulo: Revista dos Tribunais, 2007

MIRANDA, Ludmila Marcato. Da aplicação da teoria da carga dinâmica da prova nas ações ambientais. São Paulo: Instituto O Direito por um Planeta Verde, IMESP, 2009, v.2- p.81-98

MITIDIERO, Daniel. Bases para construção de um processo civil cooperativo: o direito processual civil no marco teórico do formalismo valorativo. Tese (Doutorado), Faculdade de Direito, Universidade Federal do Rio Grande do Sul, 2007

MONTERO AROCA, Juan. La prueba en el proceso civil. 2a edição. Madrid: Editorial Civitas, 1998

MONTESMOS, Ignácio A; MELLADO, Carlos L.A; PELLICER, Angel B; PESET, José M.G. Derecho Procesal Laboral. 7ª Edição. Valência: Tenant to Blanch, 2007. 
MORELLO, Augusto Mario. La prueba: tendencias modernas. Buenos Aires: Abeledo-Perrot, 1991.

NASCIMENTO, Amauri Mascaro do. Curso de Direito Processual do Trabalho. São Paulo: Ed.Saraiva, 1994.

NERY JUNIOR, Nelson. Princípios do Processo Civil na Constituição. São Paulo: Revista dos Tribunais, 2004.

NOGUEIRA, Pedro Henrique Pedrosa. A inversão do ônus da prova no código de defesa do consumidor como técnica de distribuição dinâmica da probatória. Revista Dialética de Direito Processual - n. 75 jun. 2009. São Paulo: Oliveira Rocha , 2009, p. 105-113

OLIVEIRA, Carlos Alberto Álvaro (org). Processo e Constituição. Rio de Janeiro: Forense, 2004.

. Do formalismo no processo civil. São Paulo: Saraiva, 2010.

. O juiz e o princípio do contraditório. Revista de Processo, São Paulo, n.37, jan./março de 1994 p.7-14,

- O processo civil na perspectiva dos direitos fundamentais. Disponível em http://www.abdpc.org.br/abdpc/artigos/Carlos\%20A\%20A\%20de\%20Oliveira(6)\%20\%20formatado.pdf. Último acesso em 10/12/2010.

Efetividade e tutela jurisdicional.(Ensaio destinado a livro em homenagem a Egaz Dirceu Moniz de Aragão) disponível no site do autor: http://www.alvarodeoliveira.com.br/home/artigos open.php?funcao=abrir\&id artigo=9. Último acesso em 10/12/2010

.O Formalismo-Valorativo no confronto com o formalismo excessivo Disponível em http://www.alvarodeoliveira.com.br/home/artigos_open.php?funcao=abrir\&id_artigo=8. Acesso em 10/12/2010 
OLIVEIRA, Paulo Eduardo Vieira de. $O$ dano pessoal no direito do trabalho. Tese (Doutorado), Faculdade de Direito, Universidade de São Paulo, 2001

OLIVEIRA, Sebastião Geraldo. Indenizações por acidente do trabalho ou doença ocupacional. São Paulo: Ed. LTr, 2006.

PACÍFICO, Luiz Eduardo Boaventura. O ônus da prova no direito processual civil. Dissertação (Mestrado), Faculdade de Direito, Universidade de São Paulo. São Paulo, 1998.

PAULA, Carlos Alberto Reis de. A especificidade do ônus da prova no processo do trabalho. São Paulo: LTr, 2001

PASCO, Mario. NASCIMENTO, Amauri Mascaro, 1932- (rev. técn.). Fundamentos do direito processual do trabalho. São Paulo: LTr, 1997.

PEGO, Rafael Foresti. A inversão do ônus da prova no direito processual do trabalho. Porto Alegre: Livraria do Advogado, 2009.

PEREIRA CAMPOS, Santiago. El proceso laboral en Uruguay. Revista internauta de practica jurídica , no.11,2002. Disponível em www.dialnet.unirioja.es/servlet/articulo/codigo=496448. Acesso em 06/11/2007

PEREIRA, Cláudio Castello de Campos. A inversão do ônus da prova como instrumento de efetividade na prestação da tutela jurisdicional dos interesses dos consumidores. Revista da Faculdade de Direito da USP. São Paulo, v. 97, p. 375-93, 2002

PERES, Antonio Galvão. Contrato Internacional de Trabalho. São Paulo: Campus Jurídico, 2009.

PESSOA, Flávia Moreira Guimarães. As regras de divisão do ônus da prova devem limitar os poderes instrutórios do juiz? Revista da ESMESE. Aracaju, n. 4, p. 117-23, jan./jun. 2003 
PEYRANO, Jorge W.; CHIAPPINI, Julio O. Lineamientos de las cargas probatórias “dinámicas”.In.: PEYRANO, Jorge W.(dir.); LÉPORI WHITE, Inês (coord.). Cargas probatorias dinámicas. Buenos Aires: Rubinzal-Culzoni, 2004.

PEYRANO, Jorge W. Nuevos lineamientos de las cargas probatórias dinámicas.In.: PEYRANO, Jorge W.(dir.); LÉPORI WHITE, Inês (coord.). Cargas probatorias dinámicas. Buenos Aires: Rubinzal-Culzoni, 2004.

. PEYRANO, Jorge W. La doctrina de las cargas probatórias dinâmicas y la máquina de impedir em mateira jurídica .In.: PEYRANO, Jorge W.(dir.); LÉPORI WHITE, Inês (coord.). Cargas probatorias dinámicas. Buenos Aires: Rubinzal-Culzoni, 2004.

PEYRANO, Marcos L. La Teoria de Las "Cargas Probatorias Dinâmicas" em la flamante Ley de Enjuiciamento Civil Española (Ley 1/2000). In.: PEYRANO, Jorge W.(dir.); LÉPORI WHITE, Inês (coord.). Cargas probatorias dinámicas. Buenos Aires: Rubinzal-Culzoni, 2004.

PLÁ RODRIGUEZ, Américo. Princípios de Direito do Trabalho. São Paulo: LTr, 2002

PRADO, Lídia Reis de Almeida Prado. O juiz e a emoção. Aspectos da Lógica da Decisão Judicial. São Paulo: Millennium, 2008.

PRIETO CASTRO, L. Manual del derecho procesal civil. Zaragoza: Libreria General, 1959

RANGEL, Rui Manuel de Freitas. O Ônus da prova no processo civil. Coimbra: Livraria Almedina, 2000.

RIBEIRO, Débora de Oliveira. Inversão do ônus da prova no código de defesa do consumidor. São Paulo, 2005. Dissertação (Mestrado) - Faculdade de Direito. Universidade de São Paulo, São Paulo. 
ROCHA, Raquel Heck Mariano. A Distribuição do ônus da prova como instrumento garantidor da igualdade das partes no processo civil brasileiro. Revista Processo e Constituição. Porto Alegre, n.1, dez.2004.

RODRIGUES, Marcelo Abelha. A distribuição do ônus da prova no Anteprojeto do Código Brasileiro de Processos Coletivos. In: GRINOVER, Ada Pellegrini Grinover; MENDES, Aluisio Gonçalves de Castro; WATANABE, Kazuo (coords.). Direito Processual Coletivo e o Anteprojeto de Código Brasileiro de Processos Coletivos. São Paulo: Revista dos Tribunais, 2007

ROSENBERG, Leo. La Carga de La Prueba. Traducción de Ernesto Krotoschin. Buenos Aires : Editorial B de f, 2002

SAKO, Emília Simeão Albino. A prova no processo do trabalho: os meios de prova e o ônus da prova nas relações de emprego e trabalho. São Paulo: LTr, 2008.

SALGADO, Edmar Souza Salgado. O princípio da efetividade no processo do trabalho. Tese (Mestrado), Faculdade de Direito, Universidade de São Paulo, 2008

SALAVERRIA, Juan Igartua. La motivación de las sentencias. Madrid: Centro de Estúdios Políticos y Constitucionales, 2003.

SANTOS, Alexandre Magno Borges Pereira. O princípio da isonomia das partes no processo do trabalho. MENS JURIS - Revista de Direito. Uberlândia, v. 1, n. 2, p. 37-55, jul./dez. 2004

SANTOS, Ernane Fidélis dos. Manual de direito processual civil. Vol. 1. São Paulo: Saraiva, 1997

SANTOS, Moacyr Amaral. Prova judiciária no cível e comercial. São Paulo: Saraiva, 1983 
SANTOS, Sandra Aparecida Sá dos. A inversão do ônus da prova: como garantia constitucional do devido processo legal. São Paulo: Ed. Revista dos Tribunais, 2006.

SARLET, Ingo Wolfgang. A eficácia dos direitos fundamentais. Porto Alegre: Ed. Livraria do Advogado Editora Ltda, 2005.

SARMENTO, Daniel. Direitos fundamentais e Relações Privadas. Rio de Janeiro: Ed. Lúmen Júris, 2004.

SCHIAVI, Mauro. Manual de direito Processual do Trabalho. São Paulo: LTr, 2009.

SENTIS MELENDO, Santiago. Nautreza da Prova. A prova é liberdade. São Paulo. Revista Unifieo. Ano V.no.8, Jan/Jun/2008.,

SILVA, José Afonso da. Curso de Direito Constitucional Positivo. São Paulo: Ed.Malheiros, 2005 .

SILVA NETO, Manoel Jorge e. Curso de direito constitucional do trabalho. São Paulo: Malheiros Ed., 1998. . Proteção constitucional dos interesses trabalhistas: difusos, coletivos e individuais homogêneos. São Paulo, LTr, 2001.

SILVA, Luís Virgílio Afonso da Silva. A Constitucionalização do Direito. Os direitos fundamentais nas relações entre particulares. Tese (Livre Docência), Faculdade de Direito, Universidade de São Paulo. São Paulo, 2004

SOARES, Fábio Costa. Acesso do Consumidor à Justiça: os fundamentos constitucionais do direito à prova e da inversão do ônus da prova. Rio de Janeiro: Lúmen Júris, 2006. 
SOUSA, Miguel Teixeira de. Aspectos do novo processo civil português. Revista Forense. Rio de Janeiro, v.338, p, 149-158, abr./jun.1997

SOUTO MAIOR, Jorge Luiz. A efetividade do processo. In: CORREIA, Marcus Orione Gonçalves (org.). Curso de direito do trabalho: vol. 4 - Direito processual do trabalho. São Paulo: LTr, 2009.

Direito Processual do Trabalho. Efetividade, Acesso à Justiça e Procedimento oral. São Paulo: LTr, 1999.

$\begin{array}{lllll}\text { Vôo } & 3459 & d a & T A M & \text { Disponível em }\end{array}$ www.flaviotartuce.adv.br/secoes/artigosc/soutomaior.doc. Último acesso em 10/12/2010

SOUZA, Fabiano Coelho de. O princípio da pré-constituição das provas no processo do trabalho. Revista Trabalhista Direito e Processo. São Paulo, no. 31 - outubro, 2009, p.152160.

STEINMETZ, Wilson. A vinculação dos particulares a direitos fundamentais. São Paulo: Ed.Malheiros, 2004.

SÜSSEKIND, Arnaldo; MARANHÃO, Délio; VIANNA, Segadas; TEIXEIRA, Lima. Instituições de direito do trabalho. Vol.II.16 ${ }^{\mathrm{a}}$. Ed. Atual. Por Arnaldo Süssekind e João de Lima Teixeira Filho. São Paulo: LTr 1996.

TARUFFO, Michele. La Studi sulla rilevanza della prova. Padova : CEDAM, 1970 La prueba de los hechos. [trad.] Jordi Ferrer Beltrán. Madrid: Editorial Trotta, 2002

TEIXEIRA FILHO, Manoel Antonio. A prova no processo do trabalho. Sao Paulo : Ltr, 2003 . Curso de Direito Processual do trabalho. São Paulo: LTr, 2009

TRINDADE, Antônio Augusto Cançado. Cançado Trindade questiona a Tese de "Gerações de Direitos Humanos" de Norberto Bobbio. Disponível em 
www.dhneto.org.br/direitos/militantes/cancadotrindade/cancado_bob.htm. Acesso em $13 \backslash 12 \backslash 2005$.

TRUEBA URBINA, Alberto. Nuevo derecho procesal del trabajo. México: Ed. Porrúa, 1975

TUCCI, Rogério Lauria. Devido processo legal e tutela jurisdicional. São Paulo, SP, Brasil : Revista dos Tribunais, 1993

VASCONCELOS, Elaine Machado. A discriminação nas relações de trabalho: a possibilidade de inversão do ônus da prova como meio eficaz de atingimento dos princípios constitucionais. Revista do TST. Brasília, v. 71, n. 2, p. 94-107, maio/ago. 2005

VERDE, Giovanni. L'onere della prova nel processo civile. Napoli : Jovene, 1974

VIANA, Márcio Túlio. Critérios para a inversão do ônus da prova no processo trabalhista. LTr: revista legislação do trabalho, São Paulo, v. 58, n. 10, p.1216-1224, out/1994.

.Aspectos polêmicos da prova no rito sumaríssimo. In: Paiva, Mário Antônio Lobato de, 1975- (coord.). A lei do rito sumaríssimo e das comissões de conciliação prévia na justiça do trabalho vistas pelos juristas. Rio de Janeiro: Forense, 2002 p.45-52

ZAGREBELSKY, Gustavo. El derecho dúctil. Madri:Trotta, 2007

ZANFERDINI, Flávia de Almeida Montigelli; GOMES, Alexandre Gir. Cargas probatórias dinâmicas no processo civil brasileiro. Revista Dialética de Direito Processual - n. 69 dez. 2008. São Paulo: Oliveira Rocha, 2008 p.17-34

ZENNI, Alessandro Severino Vallér. As regras dinâmicas de distribuição do ônus da prova e a avaliação da prova no processo laboral. LTr: revista legislação do trabalho, São Paulo, v. 63, n. 07, p.914/919, jul/1994. 
ZIMERMAN, David E. A influência dos fatores psicológicos inconscientes na decisão jurisdicional. A crise do magistrado. Themis - Revista da Escola Superior da Magistratura do Estado do Ceará

ZOLANDECK, João Carlos Adalberto. Ônus da Prova no Direito Processual Constitucional Civil e no Direito do Consumidor. Curitiba: Juruá Editora, 2009.

WALTER, Gerhard. Libre apreciación de la prueba : investigación acerca del significado, las condiciones y límites del libre convencimiento judicial. Bogotá, Colombia : Editorial Temis Librería, 1985

WAMBIER, Luiz Rodrigues; WAMBIER, Teresa Arruda Alvim. A prova do dano moral da pessoa jurídica. Revista Jurídica Notadez. Porto Alegre, n. 317, p. 7-13, mar. 2004.

WATANABE, Kazuo. Da cognição no processo civil. São Paulo: Ed Revista dos Tribunais, 1987 . Código de Defesa do Consumidor comentado pelos autores do anteprojeto. $5^{\circ}$. ed. São Paulo: Forense Universitária, 1998.

WOLKMER, Antonio Carlos. Novos Pressupostos para a Temática dos Direitos Humanos. In:Sánchez Rúbio, David; Herrera Flores, Joaquim e Carvalho, Salo. (Org.). Direitos Humanos e Globalização Fundamentos e Possibilidades desde a Teoria Crítica. Rio de Janeiro: Editora Lúmen Juris, 2004.

YARSHELL, Flávio Luiz. Antecipação da Prova sem o requisito da urgência e o Direito Autônomo à Prova. São Paulo: Editora: Malheiros, 2009 


\section{RESUMO}

Esta tese aborda a distribuição do ônus da prova no processo trabalhista pretendendo a aplicação da teoria da distribuição dinâmica do onus probandi neste ramo processual especial. $\mathrm{Na}$ primeira parte do trabalho são examinadas questões relativas aos direitos fundamentais, bem assim aos princípios constitucionais processuais, com relevo especial ao direito constitucional à prova. $\mathrm{Na}$ sequência serão estudadas as matérias relativas ao ônus da prova na teoria geral do processo, suas dimensões, os poderes instrutórios do juiz, a teoria clássica da distribuição do ônus da prova, bem assim as especificidades da inversão da prova no processo do trabalho. Segue-se a abordagem com a apresentação de teoria dinâmica do ônus da prova e sua recepção pelo direito brasileiro, apontando ainda alguns projetos legislativos que já positivam sua adoção no Brasil. Por fim, e considerando a necessidade de superação das regras estáticas do ônus da prova no direito processual do trabalho propõe-se a adoção das regras dinâmicas, partindo da necessidade de efetividade da tutela jurisdicional e concretização dos princípios da igualdade substancial, tudo em observância ao direito fundamental a um processo do trabalho justo e igualitário. Serão, ainda, abordadas algumas decisões jurisprudenciais da Justiça do Trabalho que aplicam o ônus dinâmico da prova.

\section{PALAVRAS-CHAVE: PROCESSO DO TRABALHO, ÔNUS DA PROVA, INVERSÃO DO ÔNUS DA PROVA, ÔNUS DINÂMICO DA PROVA, PRINCÍPIOS CONSTITUCIONAIS DO PROCESSO}




\section{RESUMÉ}

Cette thèse aborde la distribuition du fardeau de la preuve du processus du travail avec l'intention de l'application de la thèorie de la distribuition dynamique de 1' onus probandi dans ce sécteur processuel special. Dans la première partie du travail on examinera des questions concernnants aux Droits Fondamentaux, ainsi comme lês príncipes constitutionnels et processuels avec une remarque speciale au droit constitutionnel pour l'évaluation. Ensuite, on étudiera les matières concernnants au fardeau de la preuve dans la thèorie genérale du processus, ses dimensions, les pouvoirs des instructions du juge, la thèorie classique de la distribuition du fardeau de la preuve, ainsi comme les spécifications de l'inversion de la preuve dans le processus du travail. L'abordage suit avec la présentation de la thèorie dynamique du fardeau de la preuve et sa reception par le droit brèsilien, en montrant aussi quelques projets legislatifs qui ont déjà montré des résultats possitifs dans sa adoption au Brèsil. Enfin, et en considérant la necessité de la superation des régles statiques du fardeau de la preuve dans le droit processuel du travail propose l'adoption des régles dynamiques, dont le point de départ est la necessité d'une protetion juridique éfficace et la concretisation des

principes d'égalité réelle, tout en observant le droit fondamental à un procés du travail juste et égale. Ils seront abordes aussi quelques decisions jurisprudentiels de la Justice du Travail qui appliquent le fardeau dynamique de la preuve.

MOTS CLÉS: PROCESSUS DU TRAVAIL, FARDEAU DE LA PREUVE, INVERSION DU FARDEAU DE LA PREUVE, FARDEAU DYNAMIQUE DE LA PREUVE, PRINCÍPIES CONSTITUTIONNELS DU PROCESSUS 


\begin{abstract}
The present thesis addresses the distribution of the burden of proof in labor procedural law aiming to apply the theory of dynamic distribution of the onus probandi in this branch of special procedural law. In the first part of this paper, issues related to the fundamental rights, as well as procedural constitutional principles, will be assessed, with special emphasis to the constitutional right to poof. Subsequently, matters related to the burden of proof in general procedural theory, its dimensions, the instruction powers of the judge, the classic theory of distribution of the burden of proof, as well as the specificities of the inversion of the proof burden in labor procedural law will be analyzed. Then, an approach to the dynamic theory of the burden of proof and its reception in Brazilian law is presented, highlighting some legislative projects that already indicate the positive adoption in Brazil. Finally, and considering the urge to overcome the static rules of the proof burden in labor procedural law, we propose the adoption of the dynamic rules, from the standpoint of the need for effectiveness in jurisdictional custody and materialization of the principles of substantial equality, in observance of the fundamental right to a fair and equalitarian labor proceeding. And yet, some case law rulings of the Labor Justice applying the principle of dynamic burden of proof will be addressed.
\end{abstract}

KEYWORDS: LABOR PROCEDURAL LAW, BURDEN OF PROOF, INVERSION OF THE PROOF BURDEN, DYNAMIC BURDEN OF PROOF, PROCEDURAL CONSTITUTIONAL PRINCIPLES. 